\title{
ISLAM, RITUAL AND THE ETHICAL LIFE \\ DAWAT IN THE TABLIGHI JAMAAT IN PAKISTAN
}

\author{
Arsalan Khalid Khan \\ Charlottesville, Virginia
}

M.A. Anthropology, University of Virginia 2011

B.A. International Relations, Beloit College 2005

A Dissertation Presented to The Graduate Faculty of the University of Virginia in Candidacy for the Degree of Doctor of Philosophy

Department of Anthropology

December, 2014 


\section{Table of Contents}

1. Introduction 4

2. Islam and the Colonial Configuration of Religion

3. Ritual Ideology: Dawat, Personhood, Purity

5. From Precarious to Certain Faith: 


\section{Acknowledgements}

The research for this dissertation was funded by the Wenner-Gren Foundation, The Graduate School of Arts and Sciences at the University of Virginia, and the Department of Anthropology at the University of Virginia.

The faculty in the Department of Anthropology at UVa provided me with a warm and nurturing space to develop as a scholar. I am most indebted to my dissertation chair and adviser, Richard Handler, for his unwavering support and encouragement without which I may never have been able to see this task to completion. I consider my work mostly a dialogue with what I have learned from him over these many years. I also want to extend my gratitude to the members of my committee. Dan Lefkowitz's insights into performance helped me frame key aspects of my dissertation. Peter Metcalf consistently encouraged me to ground my theoretical arguments in ethnography, which I have tried to do. Ravindra Khare and my outside reader John Echeverri-Gent compelled me to clarify key points of the dissertation. Over the years, my understanding of anthropology has developed through courses and conversations with Ira Bashkow, Fred Damon, Eve Danziger, Susan McKinnon and John Shepherd. I have tried to incorporate a small part of what I learned from each of them in this dissertation.

I had the good fortune of being part of an intellectually vibrant network of scholars at UVa and beyond. My ongoing intellectual exchange with Jason Hickel has been among the most productive. Members of my writing group Roberto Armengol, David Flood, Julie Starr, Jack Stoetzel and Rose Wellman also deserve special mention. Over the years, I have had enriching conversations about my research with Erika Brant, Todne Thomas Chipumuro, Nauman Faizi, Emily Filler, Aysha Ghani, Chris Hewlett, Nadim Khoury, Sue Ann McCarty, Betsy Mesard, Neeti Nair, Alessandro Questa, Grace Reynolds, Omar Shaukat, and Clare Terni.

My research in Karachi would not have been possible without the support of my friend and key interlocutor, Talha Zahid, who helped me navigate the space of the Tablighi Jamaat. During my fieldwork in Karachi, I benefited from the intellectual camaraderie of a number of friends including Moneeza Ahmed, Nadir Hassan, Zahra Malkani, and Shaheryar and Rabayl Mirza. Many childhood friends also provided me with much needed breaks from my fieldwork.

My deepest gratitude is reserved for my family. A special thanks goes to Nani and my khala, Tazeen Erum, for everything. My brother Mansoor Khan has served as a constant source of inspiration for my intellectual pursuits. I am also grateful to him and Abbie Fentress Swanson for providing me with a second home in NYC. My step-father Afzal Ahmed Syed has been a patient supporter and always entertained my efforts at translation with good humor.

This dissertation is dedicated to my mother Tanveer Anjum who has been with me from the beginning. 


\section{Dissertation Abstract}

This dissertation explores the zealous commitment to a distinct form of face-toface preaching (dawat) among Pakistani Tablighis, practitioners of the transnational piety movement, the Tablighi Jamaat. Tablighis say that Muslims have abandoned their Islamic duties for "worldly" pursuits and must be brought back to Islam through dawat. They insist that only their own form of dawat, which requires lengthy and arduous travel, is capable of drawing Muslims to Islam and dismiss as "worldly" activities the efforts to spread Islam by a diverse array of Islamist actors including political parties, corporations, NGOs, and popular televangelists. I show that, for Tablighis, dawat qualifies as a "religious practice" (dini amal) because it is a divinely prescribed ritual that, when conducted in its proper form, elicits divine agency in order to create ethical relationships between speakers and listeners. These ethical relationships, I argue, are conceived in hierarchical terms and are modeled on the ideal of the relationship between the Prophet and the Companions. It is this ideal of ethical relationships that Tablighis consider the ground for the Islamic nation and the global Islamic community, and it is the failure of Islamists to live in these terms that renders them un-Islamic.

My central thesis is that dawat is built on a model of ethical action in which a person becomes an ethical subject by submitting to the authority of pious others and being "acted upon" by them. This model of ethical action locates "agency" not within the individual as it is in a modernist ontology but in the relations between persons. The distinction Tablighis draw between "religious" and "worldly" activities, then, is not about religious doctrine or belief, which they share with Islamists, but about the proper form of an Islamic community structured by a sacred hierarchy. 


\section{INTRODUCTION}

The Tablighi Jamaat is a transnational Islamic piety movement that began in the 1920s in North India, but now has a major presence in many parts of the world, especially where there are large South Asian populations. According to some scholars, the Tablighi Jamaat is the fastest growing Islamic movement in the world (Sikand 2002). Pakistan is one of the four major centers of Tablighi Jamaat activities, with millions of people from Pakistan and around the world attending the annual congregation (ijtima) at Raiwind and hundreds of thousands attending the other annual congregations in various cities across the country. Since the 1980s, the Tablighi Jamaat has grown dramatically in Pakistan. A testament to this is the large mosque complexes (markaz) that have sprung up in all the major cities, the largest of which can host anywhere from 20,000 to 50,000 worshippers. These complexes serve as key institutional nodes in a network of mosques that, either formally or informally, are affiliated with the movement. Tablighis—or practitioners of the Tablighi Jamaat—can be seen walking through Pakistan's villages, towns and cities in groups of ten or twelve dressed in the traditional shalwar-kameez, pant-legs raised above their ankles, with long flowing beards and a white Muslim cap, an image that is immediately discernable to Muslims as being in the Prophet's example (sunnat). They travel for specified periods of time, from a single day to an entire year, living in mosques, and "calling" or "inviting" (dawat) fellow Muslims to come to the mosque to pray and listen to sermons. It is their goal to draw other Muslims to Islamic practice, and specifically to the practice of dawat.

The Tablighi Jamaat aims to draw Muslims back to Islamic practice through their own distinct form of face-to-face preaching (dawat/tabligh). The term "tabligh" means to 
convey or deliver, and Tablighis use it interchangeably with the word "dawat" meaning to call or invite. In the Tablighi Jamaat, both are used interchangeably. The concept of dawat has deep roots in Islamic theology, and can be found in the Quran. The Quran states: "Who could be a better person than the one who 'called' (da'a) toward God and acted righteously" (41:33) and "There should be a group of people among you who 'call' (yad'una) to [do] good, enjoining good and forbidding evil" (3:104) (cited in Reetz 2006: 147). Tablighis interpret these Quranic injunctions to mean that it is the duty of every individual Muslim to preach the virtues of Islam to their fellow Muslims, just as the Prophet did, as a means to keep Muslims focused on Allah and "religion" (din) and protect them from the ploys of the Devil and "the world" (dunya).

Tablighi conceptions of dawat, however, are not simply about the spreading of Islamic content. Rather, Tablighis insist that it is the very form of dawat that is Islamic. Their "method of preaching" (tariqa-e-tabligh), they insist, follows the Prophet's example (sunnat), and, like all of the Prophet's actions, is divinely inspired. It is only this form, they insist, that is efficacious in spreading Islamic virtues and capable of communicating Allah's will and command. Early Tablighi accounts suggested that "method" came to the founder of the movement, Muhammad Ilyas, in a dream, implying that it was a direct gift from God, but Ilyas himself never said this. He did note, however, that it was a blessing from God and that "the closeness and the help and blessings [of God] is not to be found in the case of other methods" (cited in Sikand 2002: 131). The efficacy of dawat in soliciting Divine intervention is thus seen to depend on it being conducted in precisely the form that it was prescribed and fulfilled by the Prophet and his Companions. It is by following precisely the method of the Prophet that dawat becomes a religious practice 
(dini amal) and exclusively efficacious in spreading Islamic virtues and creating the basis for a genuine Islamic community. Henceforth, I will use the term dawat to refer to the specific Tablighi method of preaching.

This claim that their own "method" is divinely inspired leads Tablighis to reject all other forms of Islamic activism, especially those associated with Islamist political parties that have been a formidable presence in Pakistan's public sphere throughout Pakistan's history, but especially since the Islamization campaign of the military dictatorship of Zia-ul-Haq in the 1980s. Islamists, like Tablighis, claim that they are working towards the creation of an Islamic society, but for Islamists, there is no specified means by which Islam must be spread. Rather, those people should change according to changing social and political circumstances. Central to Islamism has been a statist project of creating an Islamic state governed by Islamic law (shariat), one that enforces Islamic codes and injunctions and actively creates the space for Muslims to live according to Islamic precepts. In recent years, however, Islamists have increasingly turned towards creating and controlling institutions beyond the state, like corporations and NGOs, and have become an active presence in media, such as radio, television, newspapers, and now, increasingly, social media like Facebook and Twitter. Islamists argue that these activities are "religious" insofar as they reflect the desire to advance the cause of Islam, but Tablighis reject this claim, arguing that these practices have no relationship to Islam. Tablighis insist that Islamists, whether pursuing statist goals or working beyond the state, conflate proper "religious practice" (dini amal) with "worldly activities" (dunyavi kam). Islamic virtues, they say, can only be spread through Islamic practices like dawat, not 
through practices that are themselves outside the bounds of Islam. Tablighis therefore reject any comparison between their own "religious" work and Islamist praxis.

The sharp distinction that Tablighis draw between themselves and Islamists is predicated on a particular conception of religion (din) as a set of practices authorized by the sacred sources, the Quran, Prophetic tradition (sunnat) and Islamic law (shariat), as it has been developed by Islamic scholars ('ulema). For Tablighis, religion must be distinguished from activities of "the world." Worldly activities are not in themselves good or bad. Tablighis insist that Islam has given Muslims much space in determining what do to and how to live their everyday lives as long as this does not conflict with the prescriptions of Islam. But, such generosity is not extended to Islamist praxis. Tablighis say that by conflating religious and worldly activities, Islamists orient Muslims away from proper religious practice, drawing Muslims into false projects that keep them from fulfilling their religious duties. Islamism, they insist, precludes the realization of pious virtues. Further, they insist that a "state" or any other institution that would arise from such un-Islamic activities would inevitably fail to live up to the ideals of Islam. The distinction that Tablighis draw between religious and worldly spheres anchors their critique of the mobilization of Islamic symbols by a diverse set of Islamist actors from Islam-oriented corporations, banks, and NGOs, to Islamist political parties, to the Islamic state institutions that Tablighis accuse of "not doing the work of religion."

Much has been written recently about the rise of Islamic piety movements in Muslim societies as efforts to resist the encroachment of liberalism with its distinct ideals of a secular public sphere, ideals that are themselves linked to liberal notions of individual agency, autonomy and freedom (Hirshkind 2006; Mahmood 2005). In 
Pakistan, unlike secular states like Egypt where these recent anthropological insights have been developed, the state explicitly claims to be upholding and promoting Islamic values. While many prominent Islamist political parties, organizations, and movements have eagerly embraced and defended the idea of an Islamic state, Pakistani Tablighis, practitioners of the transnational piety movement the Tablighi Jamaat, regard the pursuit of an Islamic state at best with ambivalence and at worst with trepidation. If Islamic pietists in places like Egypt aspire to erect a "counterpublic" to liberal ideals of a secular public sphere, Pakistani Tablighis invoke ideals of piety to critique what they consider the appropriation of Islam by the Islamist political parties as well as a host of other Islamist actors. These Islamic movements are often lumped together in scholarly and popular discourses informed by liberal-secular ideals because both bring religion out of the "private" sphere. In this dissertation, I use the Tablighi critique of Islamism not only to highlight the inadequacy of this liberal-secular perspective, but, crucially, also as awedge into the diverse and conflicting ways that religion" is being constructed under modern conditions.

\section{BEYOND THE TROPE OF SELF-CULTIVATION: ISLAM, ETHICS, POLITICS}

The Islamic revival has been at the center of numerous social scientific studies in recent decades. Most such studies turn on the idea that Islam itself does not make the category distinctions of Western modernity, often associated with Christian ideals, like the distinction between church and state, and thus finds itself in conflict with Western and modern thought. The most famous thesis along these lines is Samuel Huntington's (1996) The Clash of Civilizations, in which Huntington argues that the collapse of the Soviet Union and the discrediting of communism would not lead to the universal embrace 
of capitalism and democracy, but rather the emergence of a civilizational clash between the West and Christianity with other religious traditions, especially Islam. In Huntington's framework, the Islamic revival is consistent with the basic underlying doctrines of Islam and is simply a reaction to the encroachments of Western modernity. Another strand of thinking about the Islamic revival, which is more historically rigorous than the Islamicist one that Huntington draws on, is the historical sociology of Olivier Roy's (1991) The Failure of Political Islam. In this book, Roy notes that while Islamists draw on a broader "Islamic Political Imagination," what is most significant about them is how they have graphed Islamic terms onto Western political concepts, especially the idea of the state. While Roy acknowledges that the Islamic revival is far from homogenous, he understands the differences between Islamic forces to be strategic and utilitarian ones rather than substantive ideological or theological disagreements. Roy argues that the Islamic forces that make up the Islamic revival can basically be divided into those that are "top down" (Islamism) or whether they are "bottom up" (neofundamentalism), but most Islamic political movements oscillate between these poles depending on which one is more or less viable in a given political context. To be fair to Roy, he is not concerned with piety movements like the Tablighi Jamaat, but still, one finds here no effort to take seriously cultural, religious or ethical differences within the Islamic revival.

Regardless of whether one casts the Islamic revival as essentially traditional or modern, the various terms Islamism, political Islam and neofundemantalism are united by what they are not rather than what they are, and what they are not is secularized religious forces that accept the basic division between religion and state and private and public spheres that is the necessary condition for a host of modern institutions, like democracy, 
and ethical positions like human rights, liberty and free speech etc. In other words, regardless of whether Islamic movements are cast as "traditional" or "modern," they are constructed as a problem to be remedied and the solution is always secularism or secularized religion. This requires some form of religious reform, presumed to be the kind that the West underwent.

The secular assumptions that underpin the social science approach to the Islamic revival also inform the politics of liberal-secularism more generally. My interest in the difference between the Tablighi Jamaat and Islamist political activism springs from my experience witnessing the approach liberal-secularists in Pakistan take to Islamic forces that aim to draw Islam out of the "private" sphere into public life as being at essentially the same even if they employ different strategies from dawat to political participation to terrorism. Like the scholars above, the liberal-secular discourse in Pakistan presumes that the divisions between these movements is strategic and utilitarian but their goals are ultimately the same, which is the establishment of an Islamic state. In a context in which Islamic militancy and terrorism has been steadily on the rise, especially after the US invasion of Afghanistan in 2001, this tendency to collapse the difference between all Islamic forces into the category of "extremism" is increasingly common.

Given that social science theories about Islam and Islamism replicate popular assumptions drawn from liberal-secularism, and that liberal-secularist politics draws on social science theories to claim legitimacy, it is not surprising that the anthropology of Islam has taken up the task of dismantling liberal-secular assumptions with eager ferocity. Talal Asad's work $(1993,2003)$ has been central to this effort to think through secularism as a particular social and cultural formation with distinct ontological and 
epistemological commitments. In his now classic critique of the use of the category of religion in the social sciences, Asad (1993) argues that the ability to compare radically diverse traditions as species of a similar thing called "religion" rests on the assumption that religion has a transhistorical essence that allows it to be differentiated from, and subordinated to other spheres of life such as "politics" or "economics." Recently, Asad (2003) has connected this approach to religion to the political and ethical project of liberal-secularism. According to Asad, the very religious/secular distinction is constitutive of secularism, which constructs religion as a separate category from "the secular" with the aim of regulating it, often through the power of the state. This project, however, is complicated by the fact that religion and the secular are constantly blending into one another. Hence, in liberal-secular regimes, religion becomes a perpetual object of state regulation. More significant to Asad's critique though is the claim that liberalsecularism does not merely confine religion to the private sphere, for that is the claim that secularism makes about itself, but rather liberal-secularism secretes a new definition of religion in which religion itself becomes an issue of "belief" rather than embodied practice. In other words, religion becomes a set of propositions to be grasped by the mind, rather than a set of material practices. From the perspective of this modernist conception of religion, the material practices of Islam become, to borrow Mary Douglas's (1966) famous phrase, "matter out of place," impure by virtue of being beyond the boundaries of proper religion.

Asad's work has been tremendously important in understanding the peculiarity of the religion/secular and private/public distinctions in the discourses of liberal secularism. Liberal-secular regimes in places like Egypt are trying not only to contain Islam, but to 
transform Islam into what they deem a proper "religion," one that is, "anchored in personal experience, expressible as belief statements, dependent on private institutions, and practiced in one's spare time," a construction that "ensures that it is part of what is inessential to our common politics, economy, science and morality" (1993: 207). Asad shows that the narrative of modernity is on in which the secular with its attendant norms of rationality is progressively liberated from religion.

Saba Mahmood (2005) and Charles Hirshkind (2006) have built on Asad's work to show how the Islamic revival in Egypt has stridently resisted this liberal-secular project of transforming Islam into a matter of private belief. These scholars draw on Foucault's (1984) conception of ethics as the "care of the self" by which he means those practices through which an individual constitutes oneself as an ethical subject. Saba Mahmood shows that for women in an Islamic piety movement in Egypt, the embodied practices of Islam are understood to be disciplinary practices that mold subjects and direct them towards ethical action. These practices of ethical self-cultivation, Mahmood argues, defy liberal-secular conceptions of agency and freedom, in which agency is about realizing autonomy against rules imposed by society. The women in Mahmood's piety movement, on the other hand, aim to replicate in their lives rules and ideals that they derive from the Islamic tradition as a means for the cultivation of an ethical self. Similarly, Charles Hirshkind shows that sermon-listening in the Islamic Revival in Egypt is not merely about acquiring the content of Islamic knowledge but rather a religious practice that cultivates the senses and orients a person to Allah's command, thus making him or her capable of living an Islamic life. 
As will be abundantly clear, this dissertation can be seen as a direct dialogue with the work of these scholars. The notion of ethical self-cultivation has contributed greatly to our understanding of the significance of Islamic practice more generally and in Islamic piety movements specifically. It has also opened a broad field of possibility within the study of religion to look at the ways in which ritual practices, despite being highly repetitive and formulaic, can create a deep sense of self expression and emotional involvement with the sacred (Stasch 2011: 166). But, more significantly, these scholars have placed ethical self-cultivation at the center of a growing conversation in anthropology and beyond on the relationship between religion and ethics. This is both its most important contribution, and as I will argue below, its greatest shortcoming.

As I noted above, the idea of ritual practice as a mode of ethical self-cultivation has been drawn from Foucault who himself draws it form Aristotle. In a rich volume called Ordinary Ethics, Michael Lambek (2010) explains that Aristotelian conceptiokns of ethics have become important for their emphasis on practice, or, in other words, "as a function of action rather than (only) of abstract reason," as in the Kantian tradition. Lambek notes that Aristotle, unlike Kant, “does not begin with distinction between reason and its other," but rather distinguishes between several equally human forms of activity" (2010: 14). As is widely recognized, Kantian ethics centers on a basic distinction between freedom and constraint, in which what is ethical is conceived as the liberation of the subject from constraint. One can see here clearly how liberalism is formulated in relationship to Kantian ethics, and how the work of the scholars above shows clearly that Islam draws on the Aristotelian idea of ethics as a dimension of action. One comes to be an ethical subject by committing oneself to ethical action. Lambek, 
however, notes that the Foucaultian stress on ethical self-cultivation understood as practices of self-constitution does not address, or at least downplays, the intersubjective or relational aspects of ethics, or what Lambek refers to as "the call of the other" (2010: 25).

This dissertation focuses on how Tablighis understand dawat to be a means of ethical self-cultivation in much the way that Mahmood and Hirshkind have described in their work on Egyptian pietists. However, for Tablighis, dawat is also a practice that addresses the "call of the other," and it is uniquely efficacious in creating ethical selves precisely because it forges ethical relationships between Muslims in a manner that no other practice is capable of doing. Drawing on Webb Keane's (2003) notion of a semiotic ideology, which he describes as assumptions about what signs are and how they function in the world, I argue in this dissertation that Pakistani Tablighis have a distinct understanding of the power of Islamic signs to bring Muslims into ethical relationships, which are relationships based on "the good." Dawat is a means of circulating Islamic signs, and it is this circulation of Islamic signs that creates the grounds for the formation of ethical selves. In other words, dawat is a practice of the cultivation of ethical relationships, and it is through these ethical relationships - themselves forged in practice - that one comes to inhabit the virtues that Tablighis associate with Islam. The subtle shift away from self-cultivation to the cultivation of ethical relationships in this dissertation opens up the possibility of seeing how Tablighis conceptualize religion (din) as a mode of relating ethically to both the transcendental power of Allah and to other Muslims. For Tablighis, religion is not exclusively concerned with Islamic belief or doctrine, which Tablighis share with many other Islamic groups including Islamists, but 
also stipulates the form of the Islamic community structured by Islamic relationships. It is precisely the absence of these Islamic relationships among Islamists that leads Tablighis to reject them as un-Islamic.

Through my research I learned that dawat provides Tablighis with a substantial framework for ordering social relationships, and it is these relationships that Tablighi deem "religious." Building, then, on Asad's argument that "religion" does not have a universal or transhistorical essence, this dissertation will show how religion (din) as a domain is constituted in dawat by Pakistani Tablighis. I argue that dawat is decidedly "religious" for Tablighis because it entails an "ethics of relatedness" in which hierarchy assumes a central place. For Tablighis, "piety" or "religiosity" (dindaari) is understood a mode of relating hierarchically to those more pious than oneself, and a pious subject is one who possesses the ability to locate him or herself in a religious hierarchy in which a person's rights, duties, and obligations are defined by where he or she is situated in this religious hierarchy. Dawat is a ritual arena in which Muslims learn to be pious in this specific way. Tablighis insist that no such piety can be found among Islamists, who, by contrast, overwhelmingly stress the autonomy and agency of individual subjects. For this reason, Tablighis understand Islamist praxis to be not only outside the bounds of proper Islam but also inimical to Islamic virtues.

The shift from ethical self-cultivation to ethical relations that I described above also draws out some of the political implications of Islamic piety movements like the Tablighi Jamaat. The anthropology of Islam has become so deeply invested in showing how the Islamic tradition stands against the project of liberal-secularism, especially as it has been pursued by the Egyptian state, that they have partly cast the Islamic revival in 
"negative" terms by which I mean simply as a reaction to the encroachments of liberalsecularism. While this approach has yielded insights into secularism itself, it has had the unfortunate consequence of reifying the distinction between Islam and modernity, even if recast as a conflict between Islam and liberal-secularism. The very idea that Islamic movements are a "counterpublic" (Hirshkind 2006) implies a kind of reaction to something rather that an ethical project in its own right. In Pakistan, where liberalsecularists feel most embattled and beleaguered, overwhelmed by what they perceive to be the onslaught of Islamic forces, the anthropological effort to relativize Islamic movements has become the subject of public controversy. These scholars (Mahmood and Asad, in particular, have come to stand in for all of anthropology) have been harshly criticized by liberal-secular activists and scholars for romanticizing Islam and for erasing the violent consequences of Islamic forces, especially as they pertain to women (see Zia 2009). The claim is often made that anthropologists have resurrected the idea of an "authentic" Islamic tradition that must be saved from liberal-secularism, and thus have reproduced the core position of Islamist politics.

My own desire to understand the Tablighi Jamaat on its own terms will, undoubtedly, be criticized for similar reasons (in fact, it already has been), but I believe one way to respond to these critiques is to engage substantially with the particular forms of life that Islamic movements hope to erect and propagate rather than assume that these stand exclusively in opposition to liberal-secularism. In this dissertation, I show not only that Talighi conceptions of ethical life are at variance with liberal-secularism, but also that they stand in opposition to both "traditional" forms of Islam, organized around sacred genealogy, and modernist forms of Islam, like Islamism. I hope that by 
demonstrating that there are multiple forms of Islam in Pakistan and that Tablighis represent only one variety will demonstrate that Tablighis are not simply reacting and responding to liberal-secularism, but are actively trying to create a world based on their own conceptions of the good.

\section{FIELDWORK IN A SPACE OF CULTURAL INTIMACY}

When I saw Talha, I had to contain my shock. He wore a starched and crisply ironed white kurta and sported a long flowing beard with his mustache shaved, a style that was immediately discernable to anyone in Pakistan as being in the example of the Prophet (sunnat). For years, my friends - our mutual friends - had been telling me that Talha had become a maulvi, a term that means a religious scholar but is also used derisively by more liberal and secular oriented people as someone who is fanatical and closed minded. Some said this with shock and dismay, others with mild amusement and still others with total disdain. I admit that, it was hard to contain my shock of seeing someone who I thought I had known seem so dramatically different from how you remembered them. As we embraced each other in the courtyard of the Makki masjid, the old Tablighi mosque and center in Karachi, I could not help wonder how I should proceed with the conversation without making my discomfort known and without making things too uncomfortable. As we began to chat, the discomfort dissipated and what was a very old and important friendship surfaced as if it was always there.

I had grown up in Karachi, though I had also lived as a child for six years in the US, while my mother was completing her graduate education. Talha and I had met in our first year of A Levels or in $12^{\text {th }}$ grade. He was quiet and contemplative, much less 
inclined to the kind of back and forth mocking, or as we called it "taking," characteristic of young men in urban Pakistan. This is a phenomenon that seems to cut across class and ethnic groups, a kind of play that verges on aggression and can sometimes even turn into real conflict but helps to mark the boundaries of "insiders" and "outsiders." Everyone has to be able to dish it out as well as take it. Talha was quite capable of throwing verbal blows but generally preferred not to. He seemed to always stand above petty squabbles, except when he was defending himself. We called him "turtle" because he moved slowly, and because, I suppose, he had a protective shell around him. Like the rest of us, Talha indulged in activities that this person standing in front of me who was crafting himself in the image of the Prophet would later describe to me as "very advanced" and "way outside the bounds of Islam." For reasons of his privacy, and to a lesser extent my own, I will not describe the details of this life, which he undoubtedly would like to keep between us, but because Talha would go on to become my key interlocutor and the person who enabled my ethnography, I must begin on a note of honesty and intimacy, one that reveals something both about my own positionality and about the kind of field site I was trying to navigate.

The encounter I described above occurred in June of 2009. I had just finished my third year of graduate school and was conducting preliminary fieldwork and trying to work towards my dissertation proposal. I had known that my old high-school friend had joined the Tablighi Jamaat, or had been "ensnared in their web" as one of my other friends said, but that's about all I really knew. We had not spoken since 2002 when he moved to Toronto from New Jersey, which is where I had last seen him at a friends' reunion. When I arrived in Karachi in May of 2010 for my fieldwork I had no intention 
of reconnecting with Talha or building my research around him. I thought that I might encounter him and that he might become one of my many interlocutors, but I had never imagined it would be much more than that. In fact, I must confess, that it was hard for me, given what I knew about him, to conceive of him as an "authentic" representative of the movement. In part I think my reluctance to go directly through Talha was motivated by my own sense that he was not "other" enough.

In many ways, despite the now well-known critique of the culture concept, and despite the fact that many anthropologists are now engaged in projects that deal with middle and upper-class professionals, the quest for finding radical cultural alterity remained, at least in my mind, central to anthropology. I was convinced that the Tablighi Jamaat was sufficiently different from what we in anthropology too often gloss as "Western" (with the continued association that term has with a normative, Western model of modernity) and therefore a good candidate for ethnographic research. This was evidenced, in my mind, by the overtly ritualistic character of the Tablighi Jamaat, a character that immediately stood out to me as different from both liberal-secularism and Islamism. However, if cultural alterity was what I was invested in, then Talha's presence and the intimacy that we shared seemed to make the movement less worthy of anthropological study. To study someone from my own upper middle-class background, I thought, who, like me, had spent much of his life going to English-medium schools, and, who, like me, had spent a considerable amount of time living abroad, in the US and later Canada, made for an insufficiently "other" subject.

When I returned to Pakistan, my goal was to seek out a Tablighi mosque to which I had absolutely no attachment, preferably in a lower class area, because somehow this fit 
with my idea of what it meant to be in "the field." From my pre-field experience as well as from my readings, I knew that Tablighi were notoriously difficult to study because they did not want to be the objects of research. They saw research as an obstacle to "doing" Islam. This is a theme I will take up thoroughly in Chapter 3 and especially in Chapter 4, but it shaped my fieldwork decisions considerably, so it is worth addressing here as well. During my preliminary fieldwork, I had met a number of Tablighis at the two grand Tablighi mosque complexes in Karachi, Makki Masjid and Madni Masjid. Of the many Tablighis that I tried to build relationships with, only two agreed to meet with me beyond the mosque. All the others told me I should seek out Tablighis in my own neighborhood because that is how one "comes to Islam properly." In meetings that happened in and around the market where they worked, we exchanged pleasantries, and I explained to them the aims of my research. They explained to me that only dawat would bring me the understanding I was seeking, not research (tahqiqat), and then they would narrate the virtues of dawat. They were rarely interested in giving away information about themselves and even less interested in taking me to their neighborhood mosques, a fact that was deeply frustrating, and made me wonder if this research was even possible.

At the same time that I was struggling to find Tablighis who were willing to engage with my research plans, Talha had been contacting me regularly, asking me how things were going in my research, and expressing his interest in meeting. He came to my apartment on a few occasions, usually close to dusk prayer times (maghrib). We would go to the mosque and then we would venture out for juice or tea, and sit in the car and talk, sometimes about dawat and sometimes about our own friends and families. It was obvious that Talha was invested in drawing me to dawat but he also wanted to rekindle 
an old friendship. He seemed to think that my research would ultimately serve to bring me to Islamic practice, unlike others who thought it entirely inimical to Islamic practice, and that over time, I would find myself less interested in my research and more interested in dawat. This created a space between us that allowed me to both ask him substantial questions about the Tablighi congregation and for him to give me dawat in a manner that was in keeping with his ideas about dawat as a practice. Again, I will unpack what Tablighis mean by practice (amal) as we move through this dissertation (especially Chapter 3). For now, I simply want to note that Talha and I had found something of a common ground in which he felt he could achieve what he wanted to achieve and I felt I could do the same. In other words, we became each other's projects.

On one of his visits, Talha told me that he was forming a jamaat or group that was departing on a forty-day trip (chilla), which Tablighis are supposed to conduct each year. He asked me to accompany him. The trip would entail fifteen days of travel from Karachi to an at that point undisclosed destination to the three-day annual national congregation (ijtimah) of the Tablighi Jamaat in Raiwind, Punjab, and from there to other parts of the country for the remaining period. I agreed to accompany him till the annual congregation. This trip took us from Karachi to Multan and from there to Raiwind for a total of eighteen days. There is no question that I learned a tremendous amount about the structure of dawat during this trip, but, more significantly, I discovered how the kind of intimacy Talha and I shared was precisely the grounds upon which the dawat worked as a practice of ethical cultivation. The Tablighi Jamaat was made up of a network of relations of kinship and friendship, and Tablighis understood that it was these relationships that kept people in the movement. I realized very early in my research this is 
precisely why so many of the strangers I encountered told me to connect with my own local mosque, which they imagined as a site of familial and neighborly intimacy.

Talha was a close confidant, caregiver and "son" to a prominent Tablighi Elder (buzurg) who sat on both the city and national councils (shura) and was highly revered and extremely influential. He went by the title Hazrat, a term of respect that Pakistani Muslims use as an honorific before the names of Prophets, including the Prophet Muhammad. Hazrat was an authorized Sufi sheikh of the Chisti order. He could trace his unbroken spiritual lineage back to the Prophet Muhammad through the founder of the Chisti order. As an authorized sheikh, Hazrat had "followers" (murids) in the thousands who devoted themselves to him through an initiation called bayt, which entails a formalized commitment to follow the sheikh's every instruction. Hazrat maintained a spiritual house (khanqa) where he received people who needed his guidance. The spiritual house was also a space of special Sufi practices, including various forms of remembrance (zikr) that are not trained in the Tablighi Jamaat itself. Hazrat's followers were not all Tablighis, though he encouraged them all to be, and not all Tablighis were Hazrat's followers, but Hazrat believed that dawat was the necessary condition for all spiritual reform and realization (islah). He insisted that while he had some esoteric knowledge ('ilm), he believed this was no substitute for dawat, which is something he himself had to do to stay on the right path. In this way, Hazrat insisted that dawat superseded all other Islamic activities.

For reasons I do not fully understand, Hazrat took a liking to me and told Talha to bring me with him to khanqa. From then onwards I was treated as Hazrat's "guest," and this is an identity I carried with me into many Tablighi spaces. I will venture to say that 
Hazrat saw some potential in me as a Tablighi, but he also recognized how much Talha wanted me to be part of his world, and this led him to extend an extra level of generosity and kindness towards me. This did not go unnoticed for others in Hazrat's network. Several Tablighis told me that they did not fully understand why Hazrat had taken such a liking to me, and I could tell that this inspired a level of jealousy in them. In any case, Hazrat's endorsement of me became pivotal for my research, as people who knew of my relationship with him simply accepted or had to accept my presence. They could not go against Hazrat's wishes and many of them assumed that he had a purpose that they could not fully understand. Through Hazrat's khanqa, I worked my way to the Al-Aqsa mosque, which was around the corner from the khanqa. Each week Hazrat delivered a sermon there, which was attended by hundreds of people. The Al-Aqsa mosque has the greatest number of Tablighis that I found anywhere in Karachi, and they all attributed this, first to Allah's grace, and then to Hazrat's "shadow," or influence over the area. Hazrat, they said, had singlehandedly created the passion for dawat in this area starting some three decades ago. They frequently recalled how in decades past, Hazrat would wander alone from house to house in the scorching sun inviting people to mosque when nobody knew anything about dawat, and the fruits of this labor could now be seen in the fact that the Al-Aqsa neighborhood was a model for other neighborhoods throughout the city and country.

Many, though not all of the Tablighis centrally involved in Hazrat's khanqa were part of the Al-Aqsa congregation but all of the Al-Aqsa Tablighis were intimately connected to Hazrat. It was the overlap between Hazrat's khanqa and the Al-Aqsa mosque that I exploited, and through these people, I came to know many Tablighis in 
other parts of the city as well. Although Talha knew everyone at the Al-Aqsa mosque and everyone knew Talha, he did not attend the Al-Aqsa mosque except for Hazrat's sermons. His Tablighi activities were centered around the Mujahid mosque in his own area called Hill Top. Through Talha, I built relationships with the Tablighis at Mujahid as well. I settled into a network of Tablighis centered on Talha and Hazrat, and the Tablighis I met in this network became my most important interlocutors throughout my fieldwork. This was a network of largely middle to upper-middle class people with modest levels of education. Many of them were traders who owned shops though some were small to mid-size factory owners. Still others were urban professionals. There were also a number of working-class people in these networks, and I had to make an added effort to build relationships across these socio-economic divides. Nevertheless, because these mosques were both located in relatively middle- to upper-middle class areas, I made an extra effort to seek out people who lived in predominantly working class areas. I made a few of these relationships directly at the main Tablighi mosque complex. One relationship in particular became important for me: Maqsood, a taxi driver, who regularly attended the Thursday night congregation. Thursday nights are seen as a "big night" in which Tablighis from around the city congregate at the grand mosque complex, where they listen to sermons, pray and ultimately sleep in order to wake up the next day to listen and pray, before they had back to home to prepare for special Friday afternoon prayers, which they conduct in their own neighborhood mosques. I would sometimes stay the night as well, but occasionally I would return home after evening prayers. Maqsood would drive me home, which was approximately an hour away, and this became an opportunity for me to discuss the movement with someone who was not attached to 
Hazrat or Talha's network and someone who was working class. If anything, these discussions highlighted the remarkable uniformity of Tablighi discourse across socioeconomic class.

It will become apparent throughout this dissertation that "class" is not the overarching framework through which I organize my work. I do not believe that the forces underpinning the great expansion of Tablighi Jamaat's dawat activity and the piety framework in which it is embedded can be reduced to socio-economic class or status. I will have more to say about this in the next section on my fieldwork context, but for now, let me conclude this section by highlighting the issue of intimacy, how it affected my research, and what it says about the possibility of an anthropology that does not presume, and in fact cannot presume, radical cultural difference between the ethnographer and natives or radical disjuncture between "home" and "the field."

A number of scholars have critiqued the idea that "native anthropology" as it has been constructed as distinct from non-native anthropology understood as proper anthropology (Narayan 1993; Gupta and Ferguson 1997). These scholars agree that the very concept of "native anthropology" turns on the idea that anthropology proper entails an effort to understand radical cultural alterity by a normatively "Euro-American, white middle-class male," a perspective that makes all other types of researchers, like myself, into corrupted or impure versions of proper anthropologists (Gupta and Ferguson 1997: 16). This idea of anthropology is premised on a sharp disjuncture between the native and the ethnographer as well as between "home" and "the field," at the same time that it valorizes the movement between these spheres as a kind of rite of passage for becoming a genuine anthropologist, one who understands both himself and the "other." A "native 
anthropologist" from such a perspective can be nothing other than a degraded form of pure anthropology.

In a lucid and compelling essay addressing this issue, Matti Bunzl (2004) posits a Neo-Boasian alternative to what he describes as this Malinowskian framework. Bunzl notes that most efforts to dismantle the distinction between native and non-native anthropology ultimately serve to reproduce and reify this very distinction and fails to transcend the self-other dichotomy that it is built upon. For instance, in a well-known essay on native anthropology, Kirin Narayan (1993) argues that native anthropology is impossible because the very practice of ethnography creates a kind of displacement of the ethnographer such that it makes being "native" while doing ethnography impossible. Narayan, here, wants to challenge the hierarchical implications of the distinction between native and non-native anthropology, but as Bunzl rightly notes, it does so simply by claiming that all anthropologists are non-natives by virtue of doing anthropology. To this, Bunzl notes, "the idea of difference governing nonnkative anthropology is thus routinized as constitutive of all fieldwork, a fact that reinscribes ethnography as a site of encounter between a Self and an Other. In Narayan's framework, a Self can never be her own anthropologist” (2004: 436). Bunzl posits a Neo-Boasian alternative to this Malinowskian approach to cultural difference, one that takes us beyond the Self/Other dichotomy but does not erase difference. He notes that in the Boasian tradition, fieldwork is not an encounter between "ethnographic Self and native Other but, instead, draws its analytic leverage from a rigorous historicity that refigures the question of Otherness in terms of temporal rather than cultural alterity" (2004: 437). Bunzl's point is ultimately that such an approach - rather than being premised an essentialist idea of cultural difference - 
actually aims to understand the historical creation of the threshold of difference. In this sense, he argues, the task of Neo-Boasian anthropology shares with Foucaultian analysis an interest in creating a history of the present.

Bunzl's argument draws out something crucial to my own fieldwork experience, which was at the same time predicated on difference but was not and could not have been possible if it were built on essential cultural difference. My fieldwork was made possible by the idea that there was nothing essentially different about me to my interlocutors. For them, I was simply a Muslim who had abandoned Islamic practice and thus gone awry. They were not entirely wrong. There is much in my life to look back to that says I, too, could have easily gone down the path that Talha went down, and I knew that someone like Talha could have easily been drawn into the world that I now occupied. In fact, this possibility that I could be drawn to the dawat was a significant source of consternation and fear for many of the closest people in my own life, especially my mother.

My mother is an academic, poet and a self-identified feminist. Although she now teaches at a private university, she has spent her entire career working in the government education sector and specifically in government colleges for women. She frequently tells me how when she was in college, only about ten per cent of the girls wore any kind of headcovering like the hijab or Muslim veil and almost no girl wore the full-face veil or niqab. Today, she says, in those same classrooms, half of the girls are now veiled in some form or the other, and the other half feel a tremendous pressure to also do so. For many feminists like my mother, the dramatic rise of pietist practices among women index a normative framework that confine women to the "veil and four walls" (chadar aur char deevari). This is of course an oversimplication of the feminist discourse around Islamic 
practices like the veil, which most feminist critics acknowledge also enable girls to to move out of the confines of their homes and attend college. Nevertheless, my mother and others like her see general air of conservativism that necessitates covering as a threat to women's mobility and freedom.

While my mother never discouraged me from pursuing this particular topic, she did wonder what the allure of it was, and did, on occasion, express concern that it might influence me in untoward ways. I think what concerned her most was that I might adopt certain values of Tablighis as they relate to gender, and in particular their commitment to Islamic gender segregation (pardah). Such fears were very real for her as many Tablighis are just like me, from families just like mine. Stories of young men who are otherwise entirely unconcerned about religious practice but are radically transformed by their encounters with Tablighis abound. My mother's fears reflected a pervasive sense that Tablighis and non-Tablighis actually shared that Islam is a powerful force that draws people in and transforms their lives. Many in Pakistan feel the pressure to live their lives in accordance with Islamic precepts, at least in certain domains of their life, and express the desire to fulfill their ritual duties, which they perpetually feel they are neglecting. This is a sentiment that Tablighis both rely upon to draw people into the movement and try to create in people through dawat. Other, less religiously inclined Pakistanis frequently said that people are "ensared in their web" and once there could not escape it. My friend Nadir once told me that I was suffering from "Stockholm syndrome," a syndrome in which a kidnapped person becomes emotionally attached to his or her captors, and I needed some time away from them. 
The transformation Tablighis envision is already predicated on a sense of intimacy between them and their interlocutors, and a basis in a shared religious tradition. Indeed, my research depended on this presupposition on their part. In the words of one Tablighi, Hazrat endorsed my research he wanted to "keep me close" because I had "good character" (achei sifaat) and I could do great things for Islam if only I would commit myself to dawat. Hence, while my reasons for avoiding Talha as an interlocutor in the beginning were premised on an idea that continues to inform anthropological thinking about how "the field" and "the home" must be kept separate, for Tablighis the encounter between us was one in which, ideally, I would become one of them and that all differences between us would be erased. In other words, it was built on the presumption of cultural intimacy. What I mean by cultural intimacy here is not that actuality of sameness but the possibility of it, a possibility that was acknowledged not only by my Tablighi interlocutors, but also by many people in my own life. What lessons, I wonder, can be drawn from this experience of fieldwork in the space of cultural intimacy?

My research began on the assumption, which I had acquired in some capacity from my training, to seek out radical cultural alterity even as I recognized that this alterity was something of a fabrication, a fiction that required the erasure of the messy historical circumstances that constituted my relationship with my interlocutors, especially Talha. I tried desperately to keep separate the "the home" and "the field," even as my fieldwork constantly revealed how the two were intimately entangled. Ultimately, rather than resist this entanglement, I decided to embrace it and came to recognize that it constituted the very condition of possibility for my research, a condition that underlay the similarities and differences between myself and my Tablighi interlocutors. In my fieldwork, I was 
often reminded that those differences between us could be entirely effaced, which was my mother's deepest fear and my Tablighi interlocutors' deepest desire, or they could be expanded to a point that my interlocutors would lose interest in me or write me off as a "gone case" leading my research to fall apart, which was my own deepest fear. I managed this threat by trying to find a space between anthropology and Islam. I did this in many ways, most notably by making sure that I fulfilled my ritual obligations when I was in the mosque and by growing a beard, though a short beard that signaled neither my rejection of Tablighi ideals nor my full commitment to them. My Tablighi interlocutors enthusiastically embraced such acts, though they also were frustrated by my unwillingness to fully commit to dawat.

It is quite possible that what I have described above is not unique to my situation but simply a more pronounced version of what is a universal feature of fieldwork. Franz Boas (1889) stressed that people everywhere think, feel and act according to distinct historical traditions that they have learned over the course of their lives. Boasian anthropology, contrary to the now pervasive critique of the culture concept, stresses that such cultures or traditions are not bounded entities but semiotic divides or thresholds across which people are able to communicate (Bashkow 2004; Handler 2004). But, if both of these are true, then it also serves us to think about the way that ethnography as a prolonged encounter between different traditions has transformative power. Anthropologists, at least from Evans-Pritchard onwards, have recognized that the ethnographic encounter is transformative for both the natives and the anthropkologist. To some extent, everyone is a project of the people they study and ethnography always makes the anthropologist subject to other traditions and pedagogies, and that means other 
ways of thinking, feeling and acting. This feature of ethnography opens up the possibility that one can and often does become one's own object of research.

In this dissertation, I use my own positionality as a potential Tablighi as a focal point for understanding the project of the Tablighi Jamaat. There was nothing immediate or easy about the process of learning the terms of this Islamic tradition, but much of it was familiar to me before entering my fieldsite, and my interlocutors were also well aware of this fact. What I discovered was that it was actually the cultural assumptions that informed my ethnographic practice that were most at odds and even inimical to this Islamic tradition. The clash between my ethnography and their dawat is a significant part of what I explore in this dissertation.This supports Narayan's claim that ethnographic research itself generates cultural differences between anthropologist and natives, but I want to note that if it only produced displacement and difference, then it would not really be a feasible enterprise. In fact, it is the very possibility of becoming the subject of our own research that makes ethnography possible.

\section{URBAN LANDSCAPES OF PIETY: A SENSE OF CRISIS IN KARACHI}

With roughly 16 to 18 million inhabitants, Karachi is Pakistan's largest and fastest growing city. A trading port on the Arabian Sea, Karachi is located in Pakistan's province of Sindh. Prior to Partition and the Pakistani independence in 1947, Sindh was split communally between an urban Hindu minority and a largely rural Muslim peasantry (Wright 1991). During Partition, the vast majority of Hindu Sindhis emigrated to India, while millions of Urdu-speaking Muhajirs, Muslim migrants from northern India and Dehli, as well as Gujrati-speaking businessmen from Bombay and the west coast of India 
migrated to urban centers in Sindh, primarily Karachi and Hyderabad. In the 1960s and 1970s, the number of Punjabi and Pathan migrants from the North West had been steadily increasing and, during the 1980s, Karachi experienced a great upsurge in population and a growing demand for housing, transportation, electricity, water, education, and employment. The arrival of Afghan refugees in the 1980s and increasing traffic of arms from Karachi to the Afghan Jihad added to the city's volatility, as communities jockeyed for decreasing urban space and a stake in a deteriorating urban infrastructure. The rise of massive poor settlements (katchi abadis) and the expansion of the informal economy are hallmarks of this period. In the last census in 1998, approximately $50 \%$ of Karachi's population identified itself as Urdu speaking, $14 \%$ as Punjabi speaking, $11 \%$ as Pashto speaking, and only $7 \%$ and $4 \%$ as Sindhi and Balochi speakers, respectively, the latter two being majority populations in pre-Partition Karachi.

Population growth through migration in the 1970s and 1980s created intense competition for space and resources, and conflict manifested itself along ethno-linguistic lines. In 1985, mass riots arose between Pathans and the majority Muhajirs. Until this point, the Muhajir population had been largely averse to politics along ethno-linguistic lines. They supported Islamist political parties like the Jamaat-i-Islami, which as a result dominated the politics of Karachi. In 1984, a mass ethno-nationalist movement and later political party called the Muhajir Quami Movement (MQM) emerged to represent the Muhajirs. Muhajir fears that they were being squeezed out of Karachi by new migrants and increasingly ethno-nationalist assertions led to popular support for the MQM, which went on to sweep the 1988 elections, routing the Islamist parties. The MQM immediately assumed a militant cast and began to assert its control over the city through violence and 
harassment. In June 1992, citing the need to restore "law and order," the Army launched Operation Clean-up, in which thousands of MQM activists were targeted and killed. From 1992 to 1996, Karachi became the site of bloody street battles between MQM activists, a break-away faction of the MQM, and the Sindhi-dominated ruling Pakistan People's Party (PPP).

This history of violent conflict has left an indelible mark on Karachi's culture and politics with major political parties being divided on ethno-linguistic lines. The MQM remains the most powerful political force in the city, representing the majority Muhajir population; the PPP overwhelmingly represents Sindhis, who are a majority in the province; the Awami National Party (ANP) represents the migrant Pathan population. Each of these major political parties maintain their own militant arms and are linked to crime mafias and routinely come into violent conflict with one another over land and resources, frequently attacking each other's workers in what has come to be known in Karachi as "target killings." The year of my fieldwork, 2011, is considered one of the bloodiest of recent memory. The Human Rights Commission of Pakistan reports that at least 1,715 people were killed in politically motivated murders alone that year (HRCP Report 2011). Such killings almost always result in reprisals, and when the targets are prominent members of the MQM party, they lead to "strikes" in which the entire city is forcefully shut down. In recent decades, violent crime, including kidnappings and carand phone-snatching, has reached unprecedented heights, related of course to rising inflation levels of unemployment as more and more people migrate to this city. Moreover, sectarianism, which has been growing since the 1970s, has come to forefront with the increased incidence of radical Sunni militants murdering Shias, especially 
educated Shias, like doctors, who are seen as community leaders. The threat of terrorism by a number of militant outfits, especially the Tehreek-e-Taliban Pakistan (TTP) has added another dimension to the deep and pervasive sense of crisis in Karachi's population.

One might complain that framing the narrative of a city in terms of urban violence reproduces the stereotypical image of Karachi now pervasive in the Western media as "the world's most dangerous megacity" (Foreign Policy September 3, 2013). Such depictions not only erase other, equally salient, aspects of urban life, they also flatten the nature of urban violence itself, which is not a single issue with a single source. However, ignoring urban violence altogether would betray an incredibly significant aspect of life in this tumultuous city. It is not surprising that of the very few recent ethnographies set in Karachi, two of the most significant ones deal explicitly with the question of urban violence, especially as it relates to ethno-linguistic conflict. Oskar Verkaaik's (2004) Migrants and Militants: Fun and Urban Violence in Karachi deals with the everyday creation of violence in youth culture as it is manifested in the MQM political party, while Laura Ring's (2006) Zenana: Everyday Peace in a Karachi Apartment Building does the exact opposite, exploring how women are involved in peacemaking activities across fraught ethnic divides.

What I am presenting in this dissertation is far from an ethnography of violence, but I draw attention to these aspects of life in Karachi because they were never far from conversations I had with people during my time in the field, and they produce a kind of political uncertainty and a perpetual stream of discussion and debate that gives urban life in Karachi its distinctive feel. Maybe one vector of political uncertainty can be seen in the 
voracious desire for news. In Pakistan, there are now approximately twenty-seven 24hour news channels in the Urdu language alone, four more than there are channels devoted to entertainment. This desire for news reflects the need for information in order to manage life in the city, but this news and the talk that flows from it is pursued with immense passion and intrigue, as if people are trying to put together a great puzzle. As one of my friends who works in the news business jokingly remarked, "politics in Pakistan is a religion. No no, actually it is the religion of Pakistan!" Nowhere does this ring more true than in Karachi.

This is an aspect of life in the city that deserves much deeper treatment than I can give it here, but suffice it to say that people's investment in news comes from a deep sense of crisis and a desperate desire to manage that crisis. Naveeda Khan (2010) has recently edited a volume entitled Beyond Crisis: Reevaluating Pakistan, which aims to move beyond reductive explanations for Pakistan's political predicament. In the afterword, Katherine Ewing astutely observes that there are cultural, rather than just socio-economic roots to sense of crisis that people in Pakistan experience. Ewing writes, "the image of crisis is thus itself an aspect of national imaginary" created by a "sense of failure associated with the pervasive sense of continuously being on the periphery" (2010: 539). In Karachi the sense of crisis is exacerbated by the deep mistrust between ethnic and sectarian communities that derives from this history of violence. The mistrust is not only reflective of violence but is actually constitutive of it since each community feels that they are being targeted and must defend themselves against the machinations of others. The feeling that the city could rapidly degenerate into mass violence is partly why people accept and sometimes even advocate for the militarization of political parties. 
This provides a significant aspect of the backgrop against which my research on the Tablighi Jamaat's piety movement unfolded. For Tablighis, Karachi's crisis - evidenced both by everyday and dramatic forms of violence, and by deep ethno-linguistic and sectarian divisions - was among the clearest signs that Muslims had abandoned Islam and had fallen into a state of moral chaos (fitna). Indeed, it was the failure of Muslims to live in Islamic terms that explained the crisis, and it was against this background of political crisis that the Tablighi Jamaat experienced such dramatic growth from the 1990s onwards. It is crucial to recognize, however, that this sense of crisis is not caused by socio-economic changes alone but from the deep sense that the Islamic community, the sense of an overarching, transcendental unity among Muslims has given way to bloody conflict based on people's "worldly" attachments of blood, language and territory. For Tablighis, the remedy for these problems is to be found in regenerating an Islamic community through participation in the mosque and especially through dawat.

\section{A NOTE ON THE CLASS COMPOSITION OF THE TABLIGHI JAMAAT}

Generally speaking, scholars and popular commentators in Pakistan and beyond locate the concerns about Islam and piety inside the values of the urban middle class. It is therefore worth addressing the issue of class before moving forward. It is very difficult to assess the class composition of the Tablighi Jamaat not only because we do not have accurate numbers about participation, but also because "class" as an analytic concept is notoriously vague and determining class boundaries depends on a definition of class that draws social distinctions that, quite often, have little relevance in local ideologies. Presumptions that ideologies correspond to "classes" produce tautologies in which 
wherever one finds an ideological disposition, one presumes an underlying class, and wherever one finds a "class" one presumes ideology. Such an analysis, rather than exploring socially meaningful distinctions, imputes arbitrary values to presumed social distinctions. In other words, class is hardly an objective location from which to glean ideological dispositions nor should it be a privileged locus of analysis.

Nevertheless, it is necessary to address the relevance of socio-economic wellbeing for the Tablighi Jamaat movement. The Tablighi Jamaat requires that each individual contribute resources for all activities associated with the movement. Captured in the refrain "energy, money, time" (jaan, maal, waqt), committing one's own resources is one of the three forms of sacrifice (qurbani) that dawat entails and it is this sacrifice, Tablighis insist, that gives dawat its efficacy. Participation in the Tablighi Jamaat, then, does depend on having some expendable income, which for the urban poor who live on meager daily wages would actually be quite substantial and would greatly limit their ability to meet their basic living expenses. Many of those who toil on daily wages and can only meet their most basic needs tend not to stay involved, beyond coming to the mosque and attending sermons. Hence, one might say that full participation in the Tablighi Jamaat does depend on a basic level of economic well-being and that the poorest strata of urban Karachi find it difficult to fully participate. However, this does not mean that the ideology does not appeal to the urban poor, nor does it mean that they do not participate in any capacity. In fact, one thing I found constantly was that people in the lowest socio-economic strata of Karachi saw the Tablighi Jamaat as a possible way to acquire basic Islamic knowledge that they could not get elsewhere, and they often exhibited great respect and admiration for Tablighis. Moreover, people of the lowest 
socio-economic strata exhibited desire to participate even if full participation was not economically possible. So while one can acknowledge the financial limits to participation in the Tablighi Jamaat, one must also be careful not to narrowly define the Tablighi Jamaat in "class" terms.

Another issue that is linked to socio-economic well-being is literacy. The Tablighi Jamaat does not require literacy since most preaching activity is oral, and I personally encountered very committed Tablighis who were illiterate. Yet, literacy is an important quality in the movement because reading from a few major tracts of tales (qisse) about the time of the Prophet is itself key ritualized activity, and these tracts are understood to be primary sources of moral instruction. These tales also find their way into the oral preaching and especially in the performance of sermons (bayans). Hence, although the Tablighi Jamaat highly values oral, face-to-face forms of preaching, literacy is an extremely important asset in the movement and, arguably, a condition for full participation. I point this out because although the Tablighi Jamaat stresses that it is open to all Muslims and it is the duty of all Muslims to give dawat, textual practices in the congregation do require basic levels of literacy, and being profoundly easier for those who have basic levels of education, which creates a sense of exclusion for those who do not have those basic levels of education. However, urban centers like Karachi have relatively higher levels of literacy than rural areas. According to UNESCO (2003), Pakistan's literacy rate in urban centers in 1998 was measured at $63.08 \%$ for both males and females, but it was higher in Karachi, above $70 \%$ in most of the city. This means that literacy is not an obstacle to full participation for a majority of Karachi's population. Of course, in a city as diverse as Karachi, literacy can mean many things. It can mean having 
gone to madrassas or to government schools, or to some combination of the two. It can also mean having gone to private schools. I met Tablighis from all of these various educational backgrounds.

As I noted earlier, my research was first and foremost situated in Hazrat's network in the Al-Aqsa mosque. I used this network as a base to meet and interact with Tablighis across the city, but many of my key interlocutors were from the Al-Aqsa area. Al-Aqsa is located in the Society District of Karachi, a middle- to upper-middle class neighborhood with a large population of Muhajirs, Muslim migrants who came from North and West India during and immediately after Partition in 1947. A significant portion of these Muhajirs are Memons, Memoni speaking migrants from Gujrat, India, who are stereotypically known as (and in my experience largely were) traders. Many AlAqsa Tablighis were small- to medium-sized traders. Thee levels of education varied considerably in the Al-Aqsa congregation from doctors, engineers and other professionals who had college amd post-graduate degrees to traders who had high-school degrees to working-class people who had only primary and secondary education. A number of Tablighis were also trained in the Islamic sciences in madrassas and some of them were

'alims (scholars), muftis (legalists) and experts on Qurani recitation (hafiz). It was hard to locate any unifying sociological theme except for the fact that most had the requisite literacy and readings skills to participate fully in the life of the congregation.

\section{PLAN OF THE DISSERTATION}

The sense of crisis and uncertainty that I have described in previous sections provides the backdrop for the dramatic rise of the Tablighi Jamaat from the 1980s onwards. For Tablighis, the moral chaos (fitna) that afflicts Muslims can be attributed to 
the ethical degeration that ensues when Muslims abandon Islamic practice. This affliction, they insist, can ony be remedied through dawat. Rather than assume that Tablighis have misidentified the underlying political and economic causes of Pakistan's crisis and therefore suffer from false consciousness, this dissertation is an attempt to take seriously the religious logic through which Tablighis conceptualize moral chaos and their ideas about how to remedy it. The central thesis of my dissertation is that Tablighis understand dawat to be the sacred means for the creation of ethical relationships among Muslims. It is through the shared work of dawat and by living in the space of pious others that a Tablighi comes to inhabit Islamic virtues and acquires the capacity to live ethically with other Muslims. In this framework, the project of creating an ethical self is coterminous with the project of creating an Islamic community. I show that Tablighis conceptualize the Islamic community in terms of a sacred hierarchy, a perspective that places Tablighis at odds with modernist ideologies like Liberalism and Islamism, which are built on an ontology of egalitarian indiviualism.

The dissertation consists of an introduction, conclusion and five core chapters. In Chapter 2, I outline the historical rise of the Tablighis Jamaat in the 1920s under British colonialism. This chapter shows how British colonial efforts to create an Islamic law were premised on the distinction between the spiritual/religious and material/worldly domains, a distinction that became central to the politics of the Islamic 'ulema. In British colonial epistemology, Muslims and Hindus constituted two essentially distinct religious communities. The premise of the autonomy of religious communities required the creation of consistent and coherent Islamic and Hindu laws that could be applied consistently to each religious community. The creation of an Islamic law that was 
coherent and consistent required the codification of an Islamic cannon. I argue that the colonial process of objectification of religion in texts created a paradoxical situation for the 'ulema. On the one hand, the "ulema emerged as a new class of religious experts, which granted them increased power under colonialism. On the other hand, the texts as authentic sources could be seen by the colonial regime to stand independently of the 'ulema, therefore rendering the 'ulema dispensable. I show that the 'ulema's response to this paradox was to stress the necessary link between ritual practice and inner piety, which was the condition for Islamic knowledge. The link between ritual and piety became central to the Tablighi understanding of dawat as an Islamic practice.

Chapter 3 explores Tablighi ritual ideology as it relates to the practice of dawat. Building on the work of Saba Mahmood (2005) and Charles Hirshkind (2006), I show that dawat is understood as a practice that disciplines the practitioner and cultivates in him the ethical dispositions that allow him to live an Islamic life. I show that this understanding of dawat as a disciplinary practice is linked to the conception of a person as divided between the spirit (ruh), which humans share with angels, and the lower self (nafs), which they share with animals. Dawat shapes the lower self in terms of the spirit, thus making a person receptive and responsive to Allah's command. Tablighis refer to dawat as "the mother of practice" (umm-al-amal) because it creates the conditions for all other Islamic practice. In this chapter, I therefore push the arguments of the above mentioned scholars further by looking at how the efficacy of dawat is tied to the public commitment involved in performance, which subjects a person to the scrutiny of others and compels them to take responsibility for the ethical entailments of their performance. 
This subtle shift in approach opens up the issue of ethical relations that is so central to the argument of this dissertation.

Chapter 4 explores how Tablighi ritual ideology creates hierarchical differentiation among Muslims in terms of the relative purity and closeness to Allah. I outline what I call the ethical structure of the movement, which organizes relationships hierarchically in terms of those who are closer to their spirit and those who are closer to their lower self. I show that the dawat is understood by Tablighis as a process of spiritual growth that is homologous to the growth of a child in the womb. This understanding of dawat as process of spiritual growth structures the movement hierarchically, creating a distinction between speakers and listeners and givers and receivers of Islamic virtue and knowledge. Becoming a proper Tablighi and pious Muslim requires submitting to the judgment of those more pious than oneself, or what I call becoming a pious listener. What emerges is a form of pedagogical discipleship at all levels of the movement, which Tablighis understand to be modeled on the relationship between the Prophet and the Companions. I conclude this chapter by arguing that this form of ethical relatedness is central to Tablighi conceptions of religion (din), a perspective that place Tablighis at odds with modernist ideologies like Islamism.

Tablighis recognize that the key to embodying pious virtues is living in a pious space with pious others. In other words, piety is not an individual achievement but something that one acquires through relationships with others. In Chapter 5 I show that kin relations are understood to be especially significant in this regard, and it is only by creating spiritual home that one can become "spiritual" oneself. Tablighis believe that work in the mosque helps a person create a spiritual home, as one takes the virtues of the 
mosque to the home, but they also believe that an individual is shaped by their environment and therefore it is only by living in a spiritual home that one finds the will to keep coming to the mosque. In other words, home and mosque have a symbiotic relationship. In this chapter, I argue that certain faith is created when there is a seamless relationship between the context of the mosque and the context of the home. On the other hand, where there is a disjuncture between these contexts, people find that their faith becomes precarious. I argue that ascending a Tablighi religious hierarchy, then, is not simply an individual achievement but rather comes from harnessing the potential of one's kin relations, though this is not always realized in practice.

Chapter 6 turns to the political significance of the Tablighi Jamaat in the context of the Pakistani nation. Contrary to theories of nationalism that treat the nation as being by definition "egalitarian" and "secular," the nation in Pakistan is conceived as hierarchical and Islamic. Specifically, I argue that the Pakistani nation is structured by a basic genealogical distinction between those who have a deep Islamic past because of their "foreign" origins in Central Asia and the Middle East are understood as "high" and "pure," as opposed to those who have "local" South Asian origins and are understood as "low" and "impure." I show that the significance of the Tablighi Jamaat in Pakistan rests in how dawat by linking one to the original generative moment of Islam and by connecting one "directly" to transcendental sources (Allah, Prophet) enables one to transcend one's "worldly" and "low" origins. Here I argue that dawat is best conceptualized as a ritual of transcendence. The Tablighi Jamaat, then, provides the possibility of overturning longstanding distinctions between high and low, old and new, and pure and impure with respect to Muslim identity. 
My conclusion addresses how Tablighi conceptions of piety as ethical relatedness stands in marked contrast not only to an older genealogical model of Islam, but also the increasing prevalence of an Islam informed by modernist assumptions. In Pakistan, the neoliberal ideal of a bounded, autonomous individual not only shapes "secular" forms of life but has increasingly come to shape ideas about Islam as well. The growing prominence of individualism across "secular" and "religious" spheres is the source of deep anxieties about the loss of ethical relatedness among Pakistani Tablighis. In this chapter, I draw on Tablighi critiques of Islamist political activists to highlight how Tablighis understand the problem of modernity, which they believe to be characterized by an excess hubris and willfulness and a failure to listen and be "acted upon." By placing ultimate value on the individual, neoliberalism dismantles the kinds of hierarchical relationships that Tablighis deem ethical and therefore augurs "moral chaos." Through dawat, Tablighis aim to recreate an ethical form of life structured by hierarchical relations.

In the final analysis, I argue that the Tablighi critique of genealogy, on the one hand, and individuated being, on the other, challenges a moral narrative of modernity that goes from collective to individual, hierarchical to egalitarian and traditional to modern. Tablighi ritual ideology stands at variance with both "traditional" and "modern" forms of Islam, leading to countless debates over whether the Tablighi Jamaat is a modern movement with a "traditional" veneer or a traditional movement in a modern guise. While liberal individualism locates agency within the individual, Tablighis locate it in Islamic signs, which move between people. This movement creates hierarchical differentiation and gives the Tablighi Jamaat a traditional cast. However, Tablighi ritual 
ideology opens the possibility for transcending one's origins and becoming quite other than what one was, or, in other words, it enables one to radically change one's place in the world and imagine a future quite different from the past. I argue that the Tablighi Jamaat represents a "vernacular" Islamic modernity that forces us to rethink our conventional dichotomies of holism and individualism, hierarchy and egalitarianism, and tradition and modernity. 


\section{Chapter 2 \\ Islam and the Colonial Configuration of Religion in South Asia}

The Tablighi Jamaat was founded in the 1920s by Muhammad Ilyas, an 'alim (scholar) trained in the Dar-ul-uloom madrassa in Deoband, North India.

The 'ulema at Dar-ul-Uloom also known as the Deobandi 'ulema were the epicenter for efforts to purify Islam all practices deemed custom (rivaaj). Historians of South Asia write about this effort to purify Islamic life and revive the "original" Islam of the Quran and Prophetic tradition as "reform." The native term "islah" is closer in meaning to "correct" and is often invoked by Deobandi "ulema to mean a return to the original Islam which has been corrupted by "innovation" (bidat). This term for reform is often used alongside other term "renewal" (mujaddid) understood as a process of reviving the past or making the present conform to the past. Drawing on the teaching of the Deobandi 'ulema, Ilyas aimed to purify Islam of what were perceived as innovations (bidat) or accretions on the 'original' sources of the Quran, Prophetic tradition and Islamic law (shariat). For Ilyas, the purpose of dawat was not to convert non-Muslims but to strengthen the faith (iman) of Muslims themselves, which had become weak from living among non-Muslims and from having adopted their customs (riwaaj). Ilyas believe that "new Muslims" (ajlaf) or those who had local, South Asian roots were especially in danger of drifting away from Islam as they had never really been weaned off their customs. He insisted that that it was the responsibility of old Muslims (ashraf), or those whose families traced their roots to the Middle East and Central Asia to deliver to them the basics of Islamic knowledge and practice. For Ilyas, dawat would be the means through which the ashraf would bring the ajlaf to Islam 
The construction of religion as a distinct domain of knowledge and practice undergirds the Islamic revival, which aims to create a society based exclusively on Islamic textual sources, the Quran and the Prophetic tradition. This chapter explores how British colonialism created the possibilities for this conception of "religion" and how Islam came to be constituted as a "religion" that could not only be distinguished from other "religions," like Hinduism, but also from "custom." The distinction between religion and custom, I show, was linked directly to the systematization of textual sources in the colonial period. Specifically, I argue that demands of the colonial state to govern through Islamic law transformed textual knowledge into an autonomous source of authority and created the conditions for the emergence of new institutions like the modern madrassa that stood against older forms of genealogical authority. I argue that while this created a great boon in the power of the Islamic 'ulema who came to be seen as religious experts and keepers of the textual sources, the very same process of colonial codification also threatened to sideline the 'ulema, as textual knowledge became separable from persons. The 'ulema responded to this threat by stressing that only Islamic faith constituted through ritual is the basis for textual knowledge, placing ritual at the heart of religion. This is a conception of religion that Tablighis inherit from the Deobandi 'ulema.

It must be noted that the early $20^{\text {th }}$ century witnessed an explosion of religious revivalist activity among both Muslims and Hindus in North and West India. This period experienced intense competition between Hindu, Muslim and Christian groups over the bodies of those who were seen as ambiguous in their religiosity, specifically low-caste groups. Christian missionary work intensified during this period, which was interpreted 
by Hindus and Muslims as a policy of the colonial state. In 1908, the Hindu revivalist movement Arya Samaj (The Society of Nobles) launched the shuddhi or purification movement. The assumption behind the Arya Samaj was that Hindus had been forcefully converted first by Muslims under the Mughals and then by Christians under the British and had to be "reconverted" to Hinduism. The Arya Samaj concentrated its efforts in the Punjab, the United Provinces, and around Delhi in the Mewat region, the same area that became the focus of Tablighi Jamaat's early activity. In 1923, the Arya Samaj campaign was launched to reconvert the Malkana Rajput tribes in and around Agra. As a direct result, in 1924, Hindus and Muslims clashed in riots in the Western United Provinces. The violence that followed left an indelible mark on Muslim-Hindu relations.

Although the British treated tensions between Hindus and Muslims as the natural product of religious differences or "communalism," these conflicts were significantly shaped by the context of British colonialism. The British imagined Muslims and Hindus to be essentially distinct, mutually exclusive communities. For the British, Indian civilization was essentially Hindu and could be traced to the Vedic period. By contrast, Islamic civilization had its roots in the Middle East and Central Asia and arrived in India through a series of raids and conquests. In the British colonial imaginary, Islamic rule was despotic and had driven a spiritually rich and flourishing civilization into moral decay and dissolution (Breckenridge and van der Veer 1993; van der Veer 1994). When the British established direct rule over India after the war of independence of 1857, also known as the Mutiny, Mughal rule, coded as "Muslim," was made the explicit point of contrast to the British Raj. The British Raj was liberating Indians from the yoke of Muslim rule and reestablishing the grounds under which Indian civilization could be 
restored to its past glory. The British promised to uplift Hindus from their deplorable state of servitude to Muslims, even if they also believed this required the elimination of backward customs like child marriage and bride immolation. The British narrative of civilizational decline articulated, more generally, with Brahmanical ideas about cosmological decline, situated Brahmans as natural leaders, and placed Muslims at the center of Brahmanical anxieties about moral decay and destruction (van der Veer 1994). It resulted in a call for Hindu revival and reform and an effort to recuperate India's lost glory. From the middle of the $19^{\text {th }}$ century onwards, India witnessed what van der Veer has called the "Sanskritization" of social life or the "gradual reshaping of local beliefs and practices in the direction of Brahmanical ideals" (1994: 166). From the perspective of Brahmanical authorities, Hinduism had to be purified of the corrupting influences of Islamic rule.

The threat of Hindu revivalism created deep anxieties among Muslims that they were being eliminated from India, but this anxiety did not create anything like a unified Muslim response. Fears of both Hindu revivalism and Christian missionary work, which Muslims and Hindus both imagined to be directly tied to the policies of the colonial state, spawned several forms of dawat, one of which was the Tablighi Jamaat in North India (see Reetz 2006 151-160). The Deoband madrassa launched a Department of Preaching around the same time as the Arya Samaj's shuddhi movement and began propagating their ideas through journals like the al-Qasim and al-Rishad as well as through the establishment of Quranic schools and field offices. The prominent Deobandi 'alim, Ashraf Ali Thanwi established an organization called The Association for the Protection of Muslims (Majlis Siyanatu'l-Muslimin) in Saharanpur, the task of which was to help 
'reform' Muslim practice by bringing it in line with Islamic textual sources, whch they saw as a way to protect against the efforts of the Arya Samaj. Similarly, the Barelwi sect established a Society Pleasing to the Prophet Muhammad, and the 'ulama of Firangi Mahal, a Sufi oriented Islamic madrassa, also established their own preaching organization. The Ahmediyya, the only one of these sects condemned by the other groups for being heretics, began as a missionary movement, and they quickly turned their attention to defending the Rajput Muslims from the shudhhi movement.

Postcolonial scholars of South Asia have devoted considerable energy to documenting the role of colonialism in creating the conditions for the rise of divergent nationalist movements, the Indian nationalist movement, coded Hindu, and the Muslim nationalist movement that led to the demand for Pakistan (Pandey 1990; Chatterjee 1993; Breckenridge and Van der Veer 1993). This literature highlights the ways that British understandings of India were refracted in the self-understanding of Indian elites who went on to become the leaders of the nationalist struggle. In South Asia, the scholarly effort to de-naturalize the "nation" corresponded with the rise of radical forms of Hindu nationalism that aimed to purify the Indian nation of what were seen as "foreign" Muslim influences. My argument builds on this literature by focusing on the transformations made possible by British colonialism, but it identifies "religious nationalism" (van der Veer 1994) as only one manifestation of broader colonial configuration of religion. This broader framing asks how "religion" as a category was constructed through colonial interventions, nationalism, and the rise of new religious movements. Framing the issue this way enables us to see not only the significance of boundary-making between Hindus and Muslims, an undeniably significant part of the experience of British colonialism, but 
also the fierce polemical battles over the form and content of Islam that characterizes intra-Muslim relations. Stated differently, Hindus were the supreme other for Muslims, as Muslims were for Hindus, but "the other" is also a foil for the resolution of internal social and theological debates unleashed by the colonial experience (see Bashkow 2006). In the following chapters, it will become clear that reframing the question to ask how "religion" as an object is constructed is the only way to understand the legacy of British colonialism in postcolonial Pakistan where the struggle over the form and meaning of "Islam" is one of the defining features of social and political life. The Tablighi Jamaat is only one of many actors and movements claiming to represent the true Islam in postcolonial Pakistan. We will return to the parameters of these debates that emerged in the $19^{\text {th }}$ century in the next section, but for now, let us turn briefly to the role of the Tablighi Jamaat in the broader Islamic Revival.

According to Muhammad Ilyas, 'old' or high-caste Muslims (ashraf) have a fundamental duty to uplift 'new' or low-caste Muslims (ajlaf) by drawing them to proper Islamic practice. The true Islam, for Ilyas, could be located exclusively in three sources: the Quran, the hadith literature (documented sayings and acts of the Prophet), and the shariat or Islamic law as it had been outlined by the Islamic 'ulema. Ilyas recognized that low-caste Muslims could not learn the basics of Islamic knowledge and practice in the madrassa, so it was the duty of those with access to Islamic sources to deliver the message to them. The Tablighi Jamaat's project began among the Meos, a population who lived in the region of Mewat, 65 kilometers South West of Dehli. Like the Rajput Muslims targeted by the Arya Samaj, the Meos identified as Muslims and most were from low-caste backgrounds and had largely maintained local traditions, except they did 
maintain Islamic circumcision as well as burial practice. More significantly, Meo history was cut through by recurring conflict with the Muslim rulers of Dehli (Sikand 2002). This at least accords well with the perspective of Muhammad Ilyas who saw the Meos as only nominally Muslim. As one Tablighi ideologue would later write, "The Meos were even unaware of the appearance of namaz (mandatory prayer) itself. If perchance, a Muslim entered their territory, they would all gather together in amazement and wonder what he was up to, thinking that he might have a pain in the stomach or that he had lost complete control over his senses, because of which he was repeatedly standing up and sitting down" (cited in Sikand 2002: 110). The Meos clearly fit the model of a community that was seen as having never adopted the correct Islam. Even today, the Meos occupy a central place in Tablighi narratives as a community that transformed itself from being nominally Muslim to becoming a model of piety for all other Muslims.

Muhammad Ilyas's writings state that dawat was a fundamental duty for every individual Muslim, and his goal was not only to give dawat to the Meos but also to train them to give dawat to each other, which he insisted was the only way they would remain Muslim. According to Ilyas, Muslims have lost favor with Allah as a result of having neglected their obligations and had fallen into a state of moral chaos (fitna). This concept of "chaos" drawn from Islamic cosmology directs Ilyas's focus inwards, highlighting that for Ilyas, it was not merely the threat of Hindus or the British that necessitated dawat. Rather, dawat was necessary to combat the threats internal to Muslims themselves. Ilyas writes that it is the duty of every individual Muslim to be a muballigh or preacher. Until Muslims committed themselves to this fundamental duty, the Islamic civilization would 
remain in a state of moral degeneration, including political and economic weakness and decline.

The practice of dawat was, according to Ilyas, necessary to solicit Allah's support. There was simply no other way, Ilyas insisted, for Muslims to revive the Islamic community (ummat) and escape the state of chaos. For Ilyas, dawat was grounded in the Prophet's example (sunnat) and was, therefore, a practice (amal) in its own right. As an Islamic practice, it had to be conducted in the manner (tariqa) that the Prophet himself gave dawat. I will have much more to say about this point in Chapter 3, but for now it is worth noting that all of the Prophet's actions were seen as divinely inspired and replicating them carried with it great virtue. According to at least one account by another early Tablighi, the "method of preaching" (tariqa-e-tabligh) was itself divinely inspired and came to Ilyas in a dream. Although Ilyas did not himself say this, he insisted that dawat was a blessing from God and that "the closeness and the help and blessings [of Allah] is not to be found in the case of other methods" (cited in Sikand 2002: 131). Central to Ilyas's movement was the idea that dawat had to be conducted in a face-toface manner, not through the mediation of texts. Ilyas said that Muslims should form groups (jamaats) of 8 to 12 people and do preaching tours (gasht), and insisted that leaving one's home was the precondition for one's own reform (islah) as well as the reform of others.

I will deal with the structure of this method of dawat more thoroughly in the next chapter, but for now it's important to note that dawat, as Ilyas conceived it, was as much for the practitioner as it was for the person to whom it was directed. This is why Ilyas placed so much stress on how Muslims should relate to one another during dawat. Ilyas 
conceived of dawat as a disciplinary practice; it would discipline the lower self (nafs) and orient a person towards his spirit (ruh), transforming the Tablighi in the very act of dawat. Why, one might ask, did Ilyas place so much stress on dawat having a fixed, divinely inspired structure? Why did Ilyas believe it to be incumbent on each individual Muslim to commit himself to dawat? What moral and ethical concerns led him to believe that Muslims themselves were in need of reform? These questions are not easily answered if we understand dawat in instrumental terms, as simply a means to ward off the threat of Hindu revivalism or to increase the number of Muslims. Assuming Ilyas's conception of dawat was merely instrumental would not explain why Ilyas, and those who would follow him, would place so much stress on how dawat ought to be conducted as a divinely prescribed obligation. The efficacy of dawat depended on its form.

Tablighi understandings of dawat as having a divinely inspired structure or "method" is the central feature of the piety movement of the Tablighi Jamaat. This dissertation aims to understand the significance of this form and the larger Tablighi cosmology in which it is embedded. For Tablighis, it is precisely this form that differentiates them from all other Islamic actors and movements in Pakistan and throughout the world, even those that also claim to be doing dawat. In fact, Ilyas argued that much of what went by the name tabligh was itself a source of dissension and chaos, and was undermining Islam by leading Muslims away from proper Islamic practice. Ilyas insisted that the efficacy of dawat depended especially on the face-to-face nature of communication, insisting that the growing circulation of texts in this period was only generating religious discord and disagreement. Dawat would have the opposite effect, drawing people together and creating the possibility for Muslim unity. Ilyas's approach, 
then, represented a self-conscious effort to transcend the ideological discord generated by a host of changes unfolding in the late $19^{\text {th }}$ and early $20^{\text {th }}$ centuries, especially the rise of new print markets and an ever growing circulation of Islamic texts.

The association Ilyas draws between ideological discord and the negative impact of texts as a medium fundamentally shapes the form that dawat takes. We will return to this issue in Chapter 3, but first it is necessary to look at the conditions that created the impetus to purify Islam of innovations or accretions. This depended crucially on the assumption of a bounded, self-contained object called "religion" (din). Far from being an inevitable part of the Islamic tradition, this conception of religion was constructed in relationship to the colonial state, and specifically to the colonial state's project of creating an Islamic law. In the next section, I explore how the historical circumstances out of which this conception of religion arises.

\section{CODIFYING "RELIGION” AND “CUSTOM” UNDER COLONIALISM}

While the deep history of Islam in South Asia is beyond the scope of this chapter, I would like to outline some of the salient features of Sufi Islam that had dominated the religious landscape of South Asia throughout much of the pre-colonial era. Sufi orders proliferated across the Muslim world during the $12^{\text {th }}$ and $13^{\text {th }}$ centuries and were headed by spiritual leaders (shaikhs). The spread of Sufism to India was largely a result of the Mongol invasions, which drove these shaikhs out of Arab lands and into the Islamic sultanates of India. In India, Sufi shaikhs managed to establish their own domains of spiritual authority (wilayat). Their mystical powers were widely recognized by local populations and they came to wield tremendous power. The powers of Sufi shaikhs grew 
to such an extent that local Sultans were compelled to recognize their authority and would even negotiate with them about jurisdiction over territory (Eaton 2002).

Devotional practices aimed at soliciting the intercession of Islamic saints were integral to organizing social life for Muslims, Hindus and Sikhs in South Asia in both the pre-colonial and colonial period. These practices entailed giving alms or making supplications to living and dead saints who would then intercede (tawassul) on behalf of the practitioners to grant boons in the form of wealth, fertility and healing. Sufi saints are regarded as channels of divine vitality (barakat) due to their proximity to Allah (qurbat). They have the ability to command spiritual agents such as muwakkil and jinn who possess people, especially women, and lead them down the path of madness and impropriety. For this reason, the saint is understood to be a protector of the honor (izzat) of families. Especially powerful saints are able to perform miraculous feats like providing fertility to infertile women, bringing rain in times of drought, and facilitating growth and protection of crops. Throughout the year, saint shrines (durgahs) draw pilgrims from distant corners of South Asia who consult the saint on crucial matters of life and death. Saints are consulted or invoked during in major life cycle rituals such as the birth, marriage and death. The powers of saints are greatly augmented after their death, understood as a return to Allah (wisaal), and construed symbolically in terms of the marriage ('urs) of saint to Allah. The death anniversary of a saint ('urs) are celebratory events and they seen as occasions for earning religious merit and grace through sacrifice and giving (see Werbner 2005). Living saints are generally less powerful than dead ones, but they too perform everyday miracles, issue protective amulets (tawiz) and have the unique power to see into the hearts of people (Gilsenan 1982). 
Although not all Sufi saints are descendants of the Prophet, the most powerful are, and their power to intercede is predicated not only on the quality of their character or even their mastery of mysticism, but crucially on relations of descent to the Prophet. Prophet's descendants are said to have blood (khun) that carried divine light (nur), which grants them miraculous powers, both in this world and beyond (Ho 2006; Sanyal 1996). Most fully elaborated in the writings of Ibn-al-Arabi, the theory argues that Muhammad, the last of the Prophets, was the first being to be created from divine light, the primeval creation, which is the source of all subsequent beings. Divine light is the vital essence that animates the world and its creatures. In South Asia, the transmission of Prophetic vitality conceived in terms of light, essence and substance followed customary patrilineal channels defined by Islamic law. Divine light is transmitted through agnatic blood (khoon) from the line of the Prophet to his descendants and the patriline is conceived as the fount for divine vitality (Ho 2006).

In his remarkable study of Yemeni descendants of the Prophet (Syed) who settled along the rim of the Indian Ocean world, Enseng Ho (2006) shows how the Light of Muhammad was protected and enclosed within agnatic lines through the practice of hypergamy. Ho shows that through a theory of procreation in which Divine Light passed exclusively through male lines, which allowed the Prophet's descendants to both multiply and maintain their distinction from local populations. While marriage practices were necessary for them to establish themselves in local communities, they did not marry their own women to locals. Male descendants would marry local, non-Syed women and incorporate the children born from these unions into their lineage, but they did not give women back to their affines. Syed females only married other Syeds, which allowed them 
to create linkages across the Indian Ocean. Ho writes "Genealogy provided a sublime form of identity that could hold both pure Prophetic essence and creole human substance without contradiction" (Ho 2006: 187). In this way, Hadhrami Syeds simultaneously swelled their ranks while maintaining hierarchy and difference.

In pre-colonial South Asia, genealogy anchored a hierarchical cosmology that placed overarching value on descendants of the Prophet (syeds), followed by descendants of the companions of the Prophet (sahaba), descendants of early converts (shaikhs) of Arab descent, followed by those who could trace their roots to Central Asia (Mughals and Pathans), and finally those that were seen as local converts from Hinduism regarded as workers (kami), and in some regions like Punjab were explicitly referred to as "small Muslims" (mussali) (see Eglar 2010) A broad distinction could be drawn between the nobility (ashraf) with "foreign" origins and commoners (ajlaf) of native (i.e. Indian) origins. This division was simultaneously coded as a distinction between landowners (zamindars) and those who worked the land or handled the plow (kami) (Eglar 1960; Eaton 2002). Hierarchical distinctions were maintained through asymmetrical marriage exchange in which wife-takers were superior to wife-givers and a theory of procreation in which essence and identity passed through patrilineal descent (Alavi 1972; Eglar 1960; Lefebvre 1999). Among this nobility were hereditary Sufi saints (pirs) known as sajjada nishin (literally, keepers and the prayer rugs), and descendants of prominent Sufi saints (pirs) who maintained the shrines of their ancestors. These shrines were crucial sites of worship for much of the rural population, including even Hindus and Sikhs. Not only were these shrines sites for intercession with God but descendants of the Prophet were seen as capable of fairly adjudicating conflicts within a clan (biraderi), often between 
brothers and cousins over patrimony, and between competing biraderis over land and patronage. In this sense, sacred genealogy was integral to the functioning of pre-colonial South Asia, especially in lands where Mughal rule had extended in the North and West (Punjab, Uttar Pradesh, Sindh) and in Bengal.

When the British took formal control of India after the Mutiny of 1857, they hoped to maintain order by relying on and incorporating "traditional" authorities. In urban areas, the British sought to rule through modes of democratic self-representation and through the institutionalization of religious law, assuming an overarching distinction between "Muslims" and "Hindus," each with their own respective religious laws. By contrast, British administrators assumed that rural areas were governed less by "religion" than by "custom." This distinction between "religion" and "custom" largely drew on the socio-evolutionary paradigm developed by the Legalist Henry Maine (1861) and elaborated by the American ethnologist Lewis Henri Morgan (1877). In this socioevolutionary paradigm, societies evolve from a primitive state in which social norms and solidarities are structured by kinship understood in terms of "blood" relations to ones in which people maintain primary allegiance as individuals through contractual relations, or, in the words of Maine, from status (societas) to contract (civitas), a movement that entails the separation of kinship from legal-jural domains. In the moral geography of British colonialism, this also mapped on to "rural" and "urban" space and, as I show below, became the basis for the tripartite distinction between customary, religious, and civil law that structured the colonial political order.

British colonial policy varied significantly across colonial India, making it difficult to generalize, but it is clear that in regions with large rural Muslim populations 
like the Punjab, Uttar Pradesh, Bengal and Sindh, the British depended on the Muslim nobility and influential pir families to connect them to the mass of rural peasants (Gilmartin 1988). Here, I use the example of rural Punjab because it fully captures the conceptual distinction that British maintained between "custom" and "religion" that informed their thinking more generally and highlights the significance of "traditional" authority for the maintenance of rural social order and the collection of land revenue and taxation. Furthermore, the Punjab was predominantly Muslim and a significant portion of Punjab would become Pakistan's largest province with approximately 60 per cent of Pakistan's overall population, and the structure of colonial rule was largely inherited by the postcolonial state.

While the British maintained an overarching vision of British India as divided between religious communities of Muslims, Hindus and Sikhs, many British administrators were skeptical that "religion" captured the ethnographic reality of rural life. It was categories like "race" and "tribe" that came to dominate British understandings of rural social organization and life. In 1872, the British passed the Punjab Laws Act, which established that rural order was governed not by "religion" but by "custom" and that this should be the basis for laws of personal status, which would regulate familial affiliation, marriage and inheritance. After passing this law, revenue collectors were instructed to conduct surveys to in order to empirically verify customary practices so the laws could be codified (Anderson 1999). Lieutenant-Governor of the Punjab, Sir Robert Egerton, exclaimed in 1878, "the most fundamental basis for the division of the population in this part of India is tribal rather than religious, and should rest, not upon community of belief or ceremonial practice, but upon ancestral community 
of race, in which, whether it be genuine or only suppositious the claimants of a common origin equally believe" (cited Gilmartin 1981: 152). British administrators acted as de facto ethnographers, claiming to have understood the underlying principles that structured Muslim social life in rural areas. One prominent British official in the Punjab, C.L. Tupper argued that "Native society ... will be happier as long as it can be held together by the bonds of consanguinity" (cited in Gilmartin 1981: 153). Tupper claimed that Punjab had a "tribal" system in which "kinship and the land combine to determine and regulate the form and practice of our communities" (Gilmartin 1981: 154).

British administrators were drawing on Henry Maine's formulation of "patriarchal theory" from his work Ancient Law (1861), which he defined as "the theory of the origin of society in separate families, held together by the authority and protection of the eldest valid male ascendant" (1861: 192-93). For British administrators in the Punjab, Muslim social life was organized around kin-based loyalties of "tribes" and "clans," which they sometimes spoke of also in terms of "races," held together by bonds of agnatic blood and theories of common origin. C.L. Tupper argued that the kinship system was predicated on clan exogamy in which daughters were married "outside the closely drawn limits of the clan, but within the looser, but still remembered, circle of the tribe or race of origin" (Gilmartin 1981: 154). Tupper imagined a scenario in which giving daughters in marriage functioned to connect various "clans" in order to maintain "the sense that the clan had expanded from the family of a common ancestor" (1981: 155). This system of alliances between clans, according to Tupper, is what undergirded the entire Punjabi rural social system. According to Tupper, rural social order depended on this system of alliances but this system necessitated that inheritance pass exclusively 
through the male lines and daughters be barred from inheritance. As Gilmartin (1981, 1988) has argued, customary laws depended on excluding a great deal about local understandings of kinship, a fact that British administrators themselves occasionally noted. Nevertheless, in the interest of maintaining a stable set of traditional political brokers and steady stream of land revenue, the "agnatic theory" was defended, becoming the foundation for the development of case law in the Punjab (Gilmartin 1988). Although capturing the importance placed on agnatic blood (khoon) in the delineation of identity, especially at the top of the hierarchy, these laws ignored the pervasiveness of endogamous marriages, and the relative value placed on forms of marriage, affiliation and residence in the constitution of hierarchy in Punjab (see McKinnon 1995).

This theory was designed explicitly to facilitate the maintenance and consolidation of land in order to secure a stable and steady flow of taxation, with minimum military involvement (Washbrook 1981). Customary law exempted agricultural classes from the obligations to give rights of inheritance to women, which ensured that marriage could be contracted without fear that it could lead to the break up of landholdings, thereby ensuring that land be retained in the hands of fewer intermediaries. The Punjab Alienation of Land Act of 1901 made land belonging to "agricultural tribes" inalienable, and barred non-agricultural classes from acquiring land. This policy not only enabled an unprecedented consolidation of land, it also produced the effect of singling out some of the nobility as "natural" leaders in rural areas, many of which were themselves hereditary pirs (sajjada nishin). This relationship with "'traditional" authority would structure the politics of rural Punjab throughout the colonial period, and, as we will, see continue to shape politics in postcolonial Pakistan. 
In the Mughal period, legal scholarship thrived through patronage from the imperial court, and imperial rule depended on the legitimacy conferred by Islamic law (shariat). The emperor Aurangzeb, for instance, commissioned the Fatawa Alamgiri, a collection of opinions in the fiqh tradition that could be applied in imperial courts and the pre-colonial state sponsored legal experts or qadis drawn from the ranks of the "ulama (Anderson 1999). However, as Anderson (1999) argues, Mughal legal institutions were open only to particular high-caste groups and the "ulema who the imperial state patronized had mostly local significance. In this sense, 'ulema acted mostly to resolve local conflicts by drawing on textual knowledge. Exceptions to this like the madrassa of Firangi Mahal through the patronage of the emperor Akbar in the $16^{\text {th }}$ century, which drew scholars not only from across India but from as far away as China and Arabia. But, Firangi Mahal was controlled by a single family that traced its lineage through the scholar/mystic Khwaja Abdullah Ansari of Herat to the Prophet's Companion Ayyub Ansari, who hosted the Prophet when he was in Medina. The family of Firangi Mahal were followers of the Qadriyya Sufi order who had vowed allegiance to the pir Syed Abdur Razzaq, an illiterate holy man, and were followers of his living descendants (sajjada nishin) (Robinson 1984). As a great center of Islamic learning in pre-colonial India, the Firangi Mahal highlights how genealogical authority encompassed textual authority, or, put differently, textual knowledge was itself subsumed within genealogical lines.

If the colonial state's efforts to govern and regulate social life in rural areas revolved around the concept of "custom," in urban areas it was framed almost exclusively in terms of "religion." Well before the British state had taken formal control of India, the 
East India Company began formulating "religious" laws to help with administration in territories under its control. The Hastings Plan of 1772 established the colonial law court to adjudicate matters that fell under the areas controlled by the East India Company, stating that "in all suits regarding inheritance, succession, marriage and caste and other usages or institutions, the law of the Koran with respect to Mahomedans, and those of the Shaster with respect to the Gentoos [Hindus] shall be invariably adhered to" (cited in Zaman 2002: 21). However, as Anderson (1999) argues, the presumption that a single set of legal rules could apply to all persons professing adherence to Islam was far removed from both Islamic theory and the practice of Islamic law in South Asia. Confronted by a dizzying array of diversity of legal forms and authorities and driven by the theory that native communities should be governed by their own indigenous laws, the British aimed to create a "unified" Islamic law based on what they considered to be the authoritative texts of Islam (Zaman 2002), just as they did for Hinduism (see Mani 1998).

British judges relied on "native law officers" or court-appointed "maulvis" associated with some of the Islamic centers of learning who would guide the British judges in legal matters (Anderson 1999). However, British judges were frustrated by what they perceived as complete lack of consistency in judgment on the part of native scholars, leading them to assume that "pure integrity [was] hardly to be found" among the natives who made up the law according to their own whims (Zaman 2002: 44). Deep mistrust of native authorities and frustrations with what they understood as inconsistent interpretations of the law led the British to focus on translation and standardization of textual sources. The "Anglo Muhammadan Law," as it came to be known, was built on a narrow set of Islamic sources, and premised on the notion that the courts could not go 
beyond these authoritative sources to earlier ones. This would greatly limit the range and flexibility of juridical practice that characterized the Islamic 'ulema in the pre-colonial period (Zaman 2002). If the logic undergirding pre-colonial juridical practice was context-specific, sensitive to persons of different standing, and anchored in genealogical forms of authority, then "the law" as the British conceived it would be based exclusively on an invariant set of authoritative texts and presumed a generic Muslim self to which it could be universally and consistently applied.

This British effort to construct an "Islamic" law had a profound impact on the concomitant rise of "religion" as a conceptually distinct domain of practice. As I have suggested above, this is tied to the history of separating out textual from genealogical authority. Such a separation was conceived through an ideology that located religion in the "content" of texts rather than in the process of their construction or in the social location of persons. This process reflects Talal Asad's $(1993,2003)$ seminal argument that "religion" is largely product of the regulations of the liberal-secular state. Asad argues that liberal-secularism divides the world of institutions and practices into "private" and "public" domains, and secretes a new definition of religion in which religion becomes a matter of private belief. Indeed, almost immediately after taking formal control of India in 1857, British limited Islamic law to laws of personal status dealing with marriage, divorce, children and inheritance, leaving criminal and contractual law to the "secular" sphere. One then finds, as I suggested earlier, the tri-partite distinction customary, religious and secular law with "custom" and "religion" both competing for ascendancy in what was increasingly constructed as the "domestic" sphere. 
I draw attention to this history of the colonial state because of the profound impact it had on native conceptions of religion as a conceptually distinct domain of activity. For Islamic reform movements in the late $19^{\text {th }}$ and early $20^{\text {th }}$ centuries, religion derives its authority exclusively from the Islamic textual tradition, a tradition that in no small part owes its existence to British colonial policy. Moreover, the construction of customary and Islamic legal regimes both of which have jurisdiction over the regulation of kin relations would pit these cosmological perspectives against one another. In the next section, I explore how these Islamic movements aim to purify Islam of what are regarded as 'innovations' (bida) and a return to the pure Islam of the Prophet's era. Underwriting this project of purifying Islam is the very notion of "custom" (rivaj) seen as being inimical to Islam as it is embodied in the Quran, Prophetic tradition (sunnat), and Islamic law (shariat). It is within these reformist currents that that the Tablighi Jamaat's project must also be located.

\section{ISLAMIC AUTHORITY, RITUAL AND THE PARADOX OF OBJECTIFICATION}

Although "religious law" was circumscribed to personal status and restricted to urban areas not governed by customary law, this legal system nevertheless required religious experts and administrators, which created an immense boom in the demand for Islamic education. This was reflected in the establishment of the Dar-ul-Ulum seminary in 1867 in the North Indian town of Deoband, near Delhi. This madrassa would ultimately become a model for madrassas across South Asia, spawning what is now called the Deobandi tradition. Unlike in traditional Islamic learning, in which a student would learn by become a disciple to a prominent pir or 'alim (singular 'ulema), the Dar- 
ul-‘Ulum was organized by classes, offered a curriculum, was staffed by a paid faculty and provided living arrangements and basic necessities for its students. In this sense, it was in many ways modeled on European educational institutions (Metcalf 2004). The madrassa was born out of colonial needs for Islamic lawyers (muftis), judges (qadis) and clerks to fill a new colonial legal system. The requirements of the colonial state, then, helped create the "ulema as a centralized class of "experts" to oversee an object called "religion" (din) (Metcalf 2004).

Central to the politics of the "ulema in the colonial period was the claim that they were the rightful custodians of "religion" now understood as exclusively located in the sacred textual sources, and all other religious authority, like that of saints, fell outside the bounds of proper religiosity. Hence, the 'ulema's claim to religious authority was predicated on bounding religion as a distinct sphere of life separate from other spheres of social life over which only they had expertise. One can think about this as a process of objectification in which religion comes to be seen as a self-contained entity that can be properly explicated in terms of propositional content (cf. Keane 2007). This process of objectification required the "ulema to explicate the "religion" by turning it into propositional rules with the aim of creating a consistent, systematic and unified Islamic law. Yet, objectification also carried a peculiar risk. If the 'ulema were able to construct religion as a fully formed set of propositions, then this meant that they themselves could be displaced, enabling British authorities to administer and implement the law themselves (see Zaman 2002). This peculiar paradox, that the 'ulema's authority in relation to the colonial state depended on objectification but that objectification also meant the 'ulema could lose control of their object, consistently troubled the "ulema throughout the colonial 
period. The 'ulema responded to this by insisting that only pious Muslims who had robust faith were capable of interpreting and implementing Islamic law. The "ulema rejected the claim that Islamic law was merely a set of principles or a code that anyone could derive from the textual sources. Rather, drawing on an older religious logic, they insisted that only morally qualified or virtuous persons had the capacity to understand and administer the law. Non-Muslims and impious Muslims would inevitably be drawn to false exegesis and to "innovation" (biddat), and thus corrupt people's understanding of Islam. Moral persons here meant Muslims who had faith, performed their ritual duties and lived according to Prophet's example (sunnat). It is worth considering this feature of the Islamic tradition because it is central to Tablighi conceptions of dawat.

The 'ulema focused on the centrality of the Quran as the basis of the moral life but the Quran was not simple a receptacle for propositional truth, i.e., a book in the conventional sense of the term. As Brinkley Messick has argued, the Quran is not treated as book in the conventional sense:

The textual character of the Quran is quite different from that of the Bible, or at least the Gospels, which are considered humanly authored and which constitute a 'book' in a sense closer to the contemporary Western meaning. The Quran, by contrast, is a recitation-text. The Prophet was instructed by the Archangel Gabriel to "recite," and the Quran, an extended "recitation," was received by him and then orally reconveyed in this way to his companions (Messick 1993: 22).

The Quran is a ritual text understood by Muslims to be the direct word of God that was perfectly transmitted to the Prophet. The Quran was initially transmitted orally and only later transcribed in order to preserve it. It remains, however, primarily an oral text, which Muslims must read and recite in order to acquire divine vitality (barakat). Recitation of the Quran is integral to the performance of the mandatory prayers (namaaz). Correct 
form or style of recitation (qirat) is a necessary condition for its efficacy. The memorization of the Quran is understood as a process of "protecting" (hifz) the Quran and someone that has memorized the entirety of the text is called a "protector" of the Quran (hafiz-i-Quran). From the perspective of the 'ulema, only a person who fulfills his daily ritual obligations including the mandatory prayer as well as reading and recitation among other ritual acts is capable of interpreting and transmitting Islamic knowledge.

Central to the 'ulema's conception of moral personhood was living according to the tradition of the Prophet (sunnat). The principle source of knowledge about the ways of the Prophet is recorded in the hadith literature. Rahman (1979) defines a hadith as a "narrative, usually very short, purporting to give information about what the prophet said, did, or approved or disapproved of, or similar information about his Companions, especially the senior Companions" (cited in Woodward 1989: 61). The power of hadith to authorize or prohibit certain practices in the Islamic tradition cannot be overstated, but precisely because they are so powerful, there is the risk that they will be invented. In one widely accepted hadith, the Prophet warns of the invention of hadith:

After my death more and more sayings will be ascribed to me, just as many sayings have been ascribed to previous prophets (without their having really said them). When a saying is reported and attributed to me, compare it with God's book. Whatever is in accordance with that book is from me, whether I really said it or no (Goldzhier 1981: 42-43 cited in Woodward 1989).

The Quran is the foundational basis of all religious knowledge, the final source of truth, but the Quran does not provide prescriptions for everyday life in the same manner as the hadith literature. Hence, a critical task of the 'ulema was to verify the authenticity of hadith. This required authenticating a chain (isnad) that leads from the present to the 
Prophet's time. This "chain" entails a series of men who have orally transmitted these accounts over the generations. According to Messick, verifying a hadith requires "knowing the men" who transmitted them, ensuring that these men were morally righteous and not prone to falsification. In this sense, each hadith has it own moral genealogy. The 'ulema claimed that only they were capable of verifying such knowledge and transmitting such knowledge without falsification.

The British efforts to create an Islamic law in order to govern Muslim populations in urban areas created a new impetus for the objectification of religion. In the process, the "ulema themselves were constituted as a new category of Islamic "experts" recognized by state authority. This impetus towards objectification of religion entailed limiting the scope of Islamic juridical practice to a standardized canon of texts in order to meet the demands for a consistently applied law for all of India's Muslims (Zaman 2002). Islamic law was itself constructed against "custom" understood as habits and practices that are not authorized by the sacred sources. The distinction between "religion" and "custom" now mapped roughly onto two forms of authority, textual and genealogical. The 'ulema found themselves the keepers of religion but this also meant that they had to eliminate all other forms of authority. It is in this sense the expansion of the sphere of Islamic law became the principal political project of the Deobandi 'ulema. This required the reform or purification of beliefs and practices that fell outside of "religion." Yet, one significant threat of this relationship with the colonial state is that objectification of religion also enabled it to be appropriated by colonial powers. The ulema's response to British efforts to appropriate Islam was to insist that Islamic knowledge must be anchored in moral 
persons, ritually created and capable of living an Islamic life. In other words, it was ritual that provided the basis for Islamic knowledge.

It is precisely this link between ritual and ethical personhood that became central to the Tablighi Jamaat's insistence that dawat must take the form prescribed by Allah and be modeled on Prophet's ways. In the next chapter, I will explore this ritual ideology more thoroughly, but for now, I want to highlight how, like the 'ulema, the Tablighi Jamaat's insistence on a ritualized form of dawat is stands against the threat posed by the increased objectification of Islam in postcolonial Pakistan.

\section{CONCLUSION: DAWAT AND THE ISLAMIC PUBLIC IN PAKISTAN}

A number of relatively new Islamic revivalist movements emerged in roughly the same period as the Tablighi Jamaat, including the Barelwi movement, that aimed to reconcile the veneration of saints with the sacred sources and the Ahl-e-Hadith, who rejected even the mediation of the "ulema and saints, insisting instead on a direct, individual relationship to the sacred sources, and the Ahmediyya organized around the charismatic figure of Mirza Ghulam Ahmed. Thesee Islamic forces lead to the creation of what can be called an Islamic "public" in the sense used by Michael Warner (2002), a community structured by reference to and mobilization of the same cultural objects, namely the textual sources. These Islamic forces shared the claim that Muslim social life should be organized in relation to the Quran and the Prophetic tradition, even if they did not agree on what these sources stated. Despite their difference, they all aimed to create a return to what they saw as the original Islam of the Quran and the Prophet. As I have 
argued, this Islamic public emerged out of processes of objectification made possible by British colonialism.

The distinctness of the Tablighi Jamaat rests in its insistence that Islam can and should only be transmitted through a ritualized and face-to-face form of dawat. The Tablighi commitment to this form of dawat is far not instrumental or utilitarian. Rather, the efficacy of dawat, Tablighis insist, depends on it being conducted in its sacred form. In the next chapter, I will show how dawat is informed by a ritual ideology that privileges the spoken word and embodied action as the means for effective communication and sees texts and other forms of mediation as ineffective and even dangerous. Here, I only want to highlight that the Tablighis stresss on ritualized transmission was an effort to resist the appropriation of Islam not only the colonial state but also by other Islamic of the late $19^{\text {th }}$ and early $20^{\text {th }}$ century, including the appropriation of Islam by Muslim nationalists. For the early founders of the Tablighi Jamaaat, the objectification of Islam by other Islamic forces was leading to innovation and accretions on the original Islam and thus what was necessary to combat this through dawat.

In Pakistan, the Tablighi Jamaat has experienced dramatic growth in participation from the 1980s onwards, as evidenced by the grand mosques (markaz) that it has built in every major urban center. This is a period in which Islam came to be situated at the heart of the national project. During the state-driven Islamization program of the military dictator Zia-ul-Haq (1977 - 1988), Zia expanded the scope of Islamic law in Pakistan, mandated the teaching of a federally created syllabus for Islamic studies (Islamiyat) and generally promoted Islamic institutions. This process of state-driven objectification has had an effect similar to the British efforts to codify Islamic law; it has created immense 
competition between Islamic forces in Pakistan each of which claims to be representing the original, authentic Islam of the Prophet. For Tablighis, this competition rather than being a signal of the vitality of Islam, has created deep anxieties that Islam has been unhinged from its foundations. Once again, it is towards dawat that they turn to remedy this situation. In the next chapter, I will outline the ritual ideology and religious commitments that inform Tablighi understandings of dawat. 


\section{Chapter 3 RITUAL IDEOLOGY: DAWAT, PERSONHOOD AND PURITY}

I noted the peculiar difficulty of doing research among Pakistani Tablighis in the Introduction. Tablighis insisted that Islam is fully realized only in practice, not through "research" (tahqiqat). Practically every Tablighi I encountered told me that if I truly wanted to understand what was behind dawat, I would have to abandon my research and commit myself to "doing" dawat because dawat can only be understood by doing. Anthropologists as well as Islamicist scholars have long noted the significance of "orthopraxy" in Islam or correct forms of ritual action, and the inextricable link between knowledge and practice. In this chapter, I explore how Tablighis understand Islamic practice, and specifically the practice of dawat or ritualized preaching to be the means through which the heart is purified and through which one comes to embody the virtues of the Prophet. This chapter explores of a native theory of ritual practice or what can be called a "ritual ideology," informed by a distinct understandings of language and embodiment (see Robbins 2001). Ritual ideologies are embedded in broader "semiotic ideologies," which Webb Keane (2007) defines as "basic assumptions of what signs are and how they function in the world" (2003: 419), I argue that Tablighis have a distinct understanding of the materiality and power of sacred signs to affect a transformation in a person by drawing him into a relationship with both God and other Muslims in a way that everyday language and speech simply cannot.

This chapter reflects data collected from numerous sources including sermons and conversations with individual Tablighis over a period of 18 months. What I present in this chapter is a composite sketch of a ritual ideology that was described both explicitly 
and implicitly in discourses and practices that I found consistently across the movement. In many ways, this ritual ideology is "official" in that it is self-consciously endorsed by the leadership of the movement, the Elders who sit on the local, district, national and international councils, and it is reproduced by experienced Tablighis as part of the training of new Tablighis. My aim in this chapter is to show how Tablighis understand dawat as a practice (amaal). Obviously, what I know of this discourse, I learned through conversations with specific people, but because the model was so consistently represented, and because, part of what one is explicitly trained in inside the Tablighi Jamaat is this ritual ideology, I would like to first outline this ritual ideology, and leave the ethnographic particulars of learning and training for the next chapter.

Scholars of Islam have long recognized the central importance placed on "practice" to the Islamic tradition. Islamicist scholars differentiate Islam's focus on "orthopraxy" understood as concerns for correct practice from Christian emphasis on "orthodoxy" understood as a concern for correct theology and doctrine. For instance, the renowned Islamicist Montgomery Watt has attributed the Islamic emphasis on orthopraxy to the proclivity in Semitic thought for the "concrete over the abstract" (1998: 168). Such a distinction is built on a Cartesian mind/body duality in which the Christianity is constructed as contemplative, critical and dynamic, while Islam is construed as mindless, repetitive and static, a distinction that implies that Christianity encourages change and freedom of thought, while Islam is stagnant and, potentially, tyrannical. Anthropologists have rejected the ethnocentric premises of such distinction, but they cannot ignore the significance placed on orthopraxy in Islam. Many anthropologists have taken this as a starting point for understanding the relationship between knowledge and practice as it is 
articulated in Islamic pedagogy (Antoun 1989; Eickelman 1978, 1985; Fisher 1980;

Gilsenan 1982; Lambek 1993). In this chapter, I build on this critical scholarship.

The emphasis on orthopraxy in Islam is rooted in a conception of revelation in which all knowledge exists prior to and independent of human beings and humans must constantly strive to know what is revealed. Michael Lambek (1993) has provided an apt framework for thinking about Islamic knowledge, so it is worth considering his points. In Islam, Lambek notes, "knowledge has external, objective substance; it can be looked up, grasped, accumulated, manipulated and made practical use of by the individual ... what is critical for human beings is not establishing the existence of knowledge per se, but gaining and maintaining access to it” (1993: 4). In such a framework, the purpose of life is to acquire "objective knowledge," which is, "in theory, available to everyone" (1993: 4). Lambek here is discussing a particular egalitarian and text-based strand of the Islamic tradition, of precisely the kind that came out of the Deobandi madrassa I described in the last and informs the world view of Pakistani Tablighis. Tablighis conceptualize knowledge as something that is divinely rather than humanly created and exists independent of human beings. Here, I am concerned with what Tablighis point to when they point to "knowledge," which is not a culturally distinct form of common sense but an ideal to which people must strive. As Lambek argues, knowledge is what people explicitly point to as a valuable object. It is therefore precisely "what they do not take for granted as common sense" (1993: 9). While this dissertation is concerned with implicit assumptions that underpin Tablighi cosmology, here I am concerned with what Tablighis explicitly say about the relationship between knowledge and practice, and in particular with dawat as a form of Islamic knowledge/practice. 
As I argued in the last chapter, Tablighis derive their conception of knowledge/practice from the Deobandi tradition that grew to prominence in the $19^{\text {th }}$ and $20^{\text {th }}$ centuries centered at the Dar-ul-Uloom seminary at Deoband in North India. In this tradition, ritual practice produces the virtuous dispositions in the practitioner that allows the practitioner to faithfully live an Islamic life. Moreoever, it is this capacity that also is he condition for Islamic knowledge. As I argued, the Deobandi 'ulema stressed this aspect of the Islamic tradition against the efforts of the colonial regime to objectify Islamic knowledge for the purposes of colonial law and administration. Similarly, Tablighis insist that Islamic knowledge (ilm) must be anchored in authoritative Islamic textual sources, but it is not the purpose of each and every individual to command such textual knowledge. Textual knowledge is the preserve of those trained in the Islamic sciences, the "ulema. However, each and every Muslim must have the requisite "faith" (iman) that allows them to live an Islamic life, and this faith, Tablighis insist, derives from Islamic practice. In other words, while Islamic practice must be authenticated in the textual sources, textual knowledge is also contingent on one being practicing Muslim. What this means is that one might know or claim to know a great deal about the textual sources but this in itself does not constitute "knowledge." Tablighis say that dawat is not just any practice. It is the "mother of practices" (umm-al-amaal), which means that it creates the condition for all other Islamic practices. In the next section I turn Tablighi understandings of dawat as a practice that creates the inner dispositions that enable one to live an Islamic life. 


\section{DAWAT AS DISCIPLINARY PRACTICE}

In the Deobandi tradition, truth (haq) is embodied in the Quran, understood as the direct word of Allah, transmitted without distortion to the Prophet. The Prophet is the exemplary human being (insan-ul-kamal) who was incapable of sin and was by his very nature "innocent" (masoom) of all wrongdoing. This means that the Prophet embodied the Quran to its fullest and lived the exemplary life to which all Muslims must strive. The Prophet's sayings and actions were documented by his Companions in what is called a "hadith" and transmitted through a chain of faithful transmitters to the present day. The Quran and the hadith literature are the two principal sources of Islamic law (shariat) developed by the "ulema. It is this tradition that present day 'ulema in their struggle to obtain “objective knowledge." But, as I noted in the last chapter, this knowledge must itself be built on the ability of the "ulema including to live according to the Prophetic tradition (sunnat), or they will fail to grasp the essential truth of the Islamic tradition.

Tablighis, like many other Muslims, understand the Prophet's words and actions to have divine rather than human origins. The Prophet was a channel of Allah's will or, to borrow a term from Goffman (1981) was an "animator" rather than an "author" in that his words and actions were not of his own creation but he faithfully channeled Allah's will in his words and actions. In the Prophet, there is no gap between what Allah willed and what the he said and how he lived. This means that all of the Prophet's actions from the everyday minutia of dress, eating and sleeping to major decisions like how to marry, how to wage war, or how to govern reflect the perfect embodiment of Allah's command. It is the duty of every Muslim to emulate as closely as possible the life of the Prophet. The significance of this impetus to replicate in one's life the Prophet's example in the Islamic 
tradition is captured in the following quote by the Spanish theologian Abu Muhammad Ali Ibn Hazm (d. 1069):

If someone aspires to felicity in the next world and wisdom in this, to righteousness in his conduct, to the encompassing of all good qualities, and to becoming adapted for all excellences, he should follow the example of the Prophet Muhammad and copy in practice, as much as possible, the Prophet's character and conduct. (cited in Woodward 1989: 67).

Tablighis say that every action of the Prophet constitutes an Islamic practice (amal) and collectively these practices are what they refer to as the Prophet's way (rasool ka tariqa). According to Tablighis, all Islamic practices carry secret virtues that are not immediately recognizable to human reason (aql), which is frail and cannot fully recognize truth on its own. Tablighis constantly repeat the phrase "religion is not the name of reason," meaning that one does not immediately see the benefits that come from religious practice, but because these practices are divinely inspired, they carry hidden values and benefits to practitioners. Islamic practice carries divine vitality (barkat) and brings with it well-being (khair), and it is by molding one's life in the image of the Prophet that one draw's Allah's powers and creates well-being for oneself and for others.

Tablighis say that it is necessary for Muslims to acquire the requisite knowledge about how the Prophet lived in order to model one's own life on his life. Hence, Tablighis understand their own jamaat or congregation to be a space that provides Muslims with the requisite knowledge to live in the Prophet's way. Many described their congregation to me as "moving" or "walking" madrassa. As one Tablighis explained, "when we were younger we could go to a madrassa, but now, we would be embarrassed sitting among children, so instead we come to the jamaat where we can learn about our religion." 
Acquiring religious knowledge was a crucial part of what Tablighis believed they

accomplished in the congregation, however, they insisted that this was not simply a "mental" (zeheni) activity but an embodied one, a feature that fundamentally differentiates it from "worldly knowledge." As one Tablighis explained to me:

"The feeling of joy (lutf), comfort (itminan), and peace (sukoon) one acquires form religious knowledge (dini 'ilm) one cannot acquire from worldly knowledge (dunyavi 'ilm). Worldly knowledge ('ilm) is not really knowledge at all. It is only vocation (fan). Think about it, yesterday it was a big deal to be a BBA. You would manage a whole factory and everyone would say 'wow, how educated he is.' Before that, it was a trend to be an engineer or a doctor. Now, everyone wants to be a computer scientist. Tomorrow, who knows what people will want, but it will be something different. Knowledge is that which is forever, the knowledge Allah has bestowed upon us. The rest is just vocation. We do it because we must, but it will not mean anything in the end.

In this quote, one can see that religious knowledge is eternal and worldly knowledge is transient. Religious knowledge, they say, will carry you from here to the afterlife, serving you for eternity, while worldly knowledge, even of the most highly valued kind, may not even serve one for a few years. More significantly, as evident from the quote, religious knowledge is not just a mental activity, but it suffuses one with bodily pleasures like joy, comfort and peace. Worldly knowledge, on the other hand, might appeal to the mind (zehn) but it does not have the same embodied effects. This implies not only a stability and fixity that stands in stark contrast to the flow and flux of worldly knowledge and affairs, but also that religious knowledge brings with it bodily pleasures.

Tablighis say that one might be able to acquire such knowledge elsewhere as well, like in a madrassa, but the purpose of dawat is not just about acquiring knowledge. Rather, what the Tablighi congregation provides is the requisite faith that propels one towards "practice." In the Tablighi Jamaat one hears repeatedly the refrain, "Muslims 
know but they do not do," by which they mean that even when Muslims have knowledge about their Islamic duties, they do not have the will or desire to actually perform them. I was repeatedly told that we live in an age where the gap between knowledge and practice has never been greater. Today, one can acquire authentic Islamic knowledge in various media forms, including a vast print literature as well as audio sermons and training sessions, but this knowledge does not induce the desire for Islamic practice. It is not felt and doesn't seep into the heart. Thus, Muslims remain far from the Prophet's way.

We live in what they often referred to as an age of "negligence" (ghaflat) in which Muslims have abandoned their religious duties embodied in Prophet's way for the "ways of others" (doosron kei tareeqei). These "others" include Hindus, Jews, Christians, atheists as well as wayward Muslims like Shias and Barelwis. In the chapters to come, I will explore how Tablighis position themselves as "pure" Muslims against both internal and external others, and the values that undergird these distinctions, but for now let us focus on the supreme "other" of Tablighis, which is the Devil himself. The Devil (shaitan or Iblees) preys on what is the essential frailty of human beings. It is the single purpose of the Devil to draw Muslims away from Islamic practice by dangling the fruits of "the world" in front of him. Human frailty is of course poignantly captured in the story of Adam and Eve, which hardly needs rehearsing here. Muslims must continuously stave off the Devil's advances, but in order to do this, they need "faith" (iman) and "certainty" (yaqeen), two terms that Tablighis use interchangeably, that keeps one focused on Allah. It is the power of faith and certainty that propels one towards Islamic practice and keeps one committed to Islamic practice. As I will show below, it is through Islamic practice, 
and specifically the practice of dawat, that people grow their faith and certainty, and thus create the necessary Islamic sensibilities to live an Islamic life.

Tablighis understand the human being to be the site for a cosmic battle between religion and the world, truth (haq) and falsehood (batil), Allah and the Devil. It is Islamic practice, they say, that draws human beings away from the latter and towards the former. Tablighis insist that in these times few Muslims have the requisite "faith" and "certainty" to fulfill even their most basic ritual duties like the daily mandatory prayers, let alone the more exalted practices of the Prophet. According to my interlocutors, we live in an age of great temptation where people have forgotten the purpose of life, an age in which people have become so enamored by accouterments of "the world" and have thrown themselves into the pursuit of worldly affairs and things that they have forgotten their religious duties. As a result, the world has fallen into a state of moral chaos (fitna):

Tabligh is about making people human beings. . . Just look at the world we live in. Nobody leaves anyone's wife or sister. Would you want someone to look at your wife or sister like that? NO! Look around. See all these target killings and these problems. These are all because we have left the path of God.. . See, I was like you before. The life you've lived is like the life I lived. I never went to classes. We would skip class and go for snooker. We would wake the owner of the snooker parlor and beg him to let us in to play. We would chase after girls from DHA Women's College, and we never thought about whether what we were doing was right or wrong ... To do tabligh is to live with the fear of Allah, to know that you will have to give an account for your deeds.

This quote accurately captures the dual use of the Islamic concept of "chaos" as both "temptation" and "disorder," which is tied to the unfettered desire for "the world," most notably as it is manifest in the desire for women. For Tablighis, the ills of that afflict Muslims throughout the world are because Muslims have forsaken their religious duties and have therefore lost Allah's favor. 
Tablighis insist that it is only dawat that will bring Allah to the aid of Muslims and this is the basis for restoring moral order. Tablighis travel through Pakistan's villages, towns and cities in groups (jamaats) of 10 or 12 in order to "call" fellow Muslims to the mosque to pray and listen to sermons and learn about Islam. When they are not travelling, they partake in a highly regimented system of ritual practices, which includes both preaching and forms of reading, recitation, exhortation and admonishment. I will have more to say about the structure of Tablighi ritual activities in the next section, but for now, let me just outline the basic set of practices. Tablighi Jamaat activities are structured by what they call the "the five practices": (1) daily collective reading from their central text, the Fazail-e-Amal (The Benefits of Practice), once in the home and once in the mosque; (2) the daily consultation (mashwara) with fellow Tablighis after nightly prayers in their local mosque; (3) a weekly dawat tour (gasht) in one's own locality and another in a nearby locality; (4) one three-day dawat tour each month that takes one outside the city; (5) an annual 40 day tour (chilla) that takes one to various parts of the country. Each Tablighi should conduct one four-month tour in his life in order to qualify as an "old companion" (purana saathi) which is a designation that grants him the right and obligation to be the leader (amir) of a travelling group. On Thursday evenings, Tablighis in the tens of thousands congregate at the grand mosque complexes (markaz), where they engage in collective prayer, listening, reading and recitation and exhortation and admonishment. They spend the night at these mosque complexes, after listening to a collective prayer, after which they return to their respective neighborhood for Friday prayers. For Tablighis, all of these activities are integral to what they understand as dawat, though sometimes Tablighis speak of dawat in the more narrow 
sense of the act of preaching to others as well. I will say more about this in the following sections.

The central claim of the Tablighi movement is that giving dawat to others grows one's own "faith," solidifies "certainty," and creates the "passion" and "desire" to fulfill one's religious duties. Crucially, dawat has this effect not only on others but, more importantly, on the Tablighi practitioner himself. Dawat, Tablighis insist, is first and foremost for one's own reform or "correction" (islah) and only secondarily for the reform of others. This is one of the first things that Tablighis say when explaining the purpose of dawat to non-Tablighi like myself; one gives dawat primarily for oneself, for the sake of one's own faith and certainty, and only secondarily for others. Tablighis explained to me that when one extols the virtues of a particular practice in dawat, this "gives birth" to the desire for that specific practice in oneself. According to one Tablighi I interviewed, "if you preach the merits of the mandatory prayers, you yourself will want to do your prayers, if you preach to others the merits of fasting, you too will want to do fasting. People think that one should not give dawat if you do not do that practice yourself, but this is not right. We give dawat to others so that we realize ourselves the virtues of practice and the truth of Islam."

This transformative power of dawat on the practitioner was recounted in countless narratives. The following is one that I recorded from a sermon that typifies this genre:

A young man who was clean-shaven was going to Canada for studies and he was worried about his faith, so he decided to go visit the Imam sahib to ask what he should do to not lose his faith. When he arrived at the mosque he saw the imam sitting reading the Quran. 'Imam sahib, I am very worried that I will go abroad and be drawn away from religion. What should I do to protect my faith?' Without hesitation, the Imam said, 'spend time with Muslims and give dawat to others. Ask them to come to the mosque for prayers.' The young man agreed. A few years later, after he had completed his education, he came back to his mosque and 
the Imam was very pleased to see him. The man now had a beard, and he wore his pant legs above his ankles. His appearance was religious (dindaar). The imam asked him if he had remembered to do what he had asked. The young man nodded in affirmation. The imam asked, 'and what happened?' The young man replied, 'I felt awkward at first but because I had made a commitment, I continued to do it.' 'Did anyone ever come to the mosque?' asked the Imam. The man replied, 'no, never, but I began praying five times a day, and the rest you can see.'

In these narratives, a young man, the kind most prone to losing his way, with a modest level of faith indicated by his lack of a beard and his generally "unIslamic" demeanor, including wearing "pant-shirt" as opposed to the "traditional" shalwaar kameez, would be departing to a foreign, non-Muslim country where he is likely to be influenced by unIslamic practices. The young man goes abroad and instead of coming back less pious, as one might expect, actually comes back a much more devout and practicing Muslim than he was before he left. This is attributed to the transformative power of dawat.

This understanding of dawat fits well with the descriptions of Islamic pietists in Egypt by Saba Mahmood (2005) and Charles Hirshkind (2006) who stress that ritual practice in Islam, far from being merely symbolic or expressive, are actually understood to be disciplinary practices that cultivate ethical selves. Ritual practices like the mandatory prayer and sermon listening cultivate morally laden affective dispositions like humility, pious fear, patience, and love, which then enable one to differentiate good from bad, right from wrong, and truth from falsehood, allowing one to live an Islamic life. As Hirshkind explains, Egyptian pietists do not see sermon listening as being simply a matter of understanding the "content" of sermons. Rather, for Egyptian pietists sermon listening is understood as a disciplinary practice that "hones the senses." Sermons, Hirshkind writes, "attune the heart to God's word and incline the body to moral conduct" (2006: 9). Similarly, Tablighis speak of dawat as a disciplinary practice that produces morally laded 
affective dispositions like humility and pious fear. However, Tablighis say that dawat is not any practice but the "mother of practices" because it "faith" and "certainty" that propel one to all other Islamic practices, creating the potential in the practitioner to live an Islamic life.

The process through which dawat grows one's faith was described as having three stages. In the first stage, one feels uncomfortable and awkward speaking the praises of God. "We live in an age," one Tablighi explained, "where we speak constantly about "the world' and such talk flows like water but when we speak of Allah, our words get stuck in our throats. We cannot bring ourselves even to speak two words in praise of Allah." The contrast he draws is one frequently invoked in the Tablighi Jamaat between "worldly talk" (dunyavi batein) and "religious talk" (dini batein). For Tablighis, "religious talk" is actually not talk at all but practice (amal). The Tablighi Jamaat, he explained, is where one learns to speak as a Muslim. One comes to speak about the right things and in the right manner. Through repetition, Tablighis explained, "religious talk" becomes habit (adat), and one no longer feels awkward. The "tongue opens" and the words begin to flow, Tablighis say, because when you are speaking for God, "God moves the tongue." Finally, when one has come to speak as a Muslim, one begins to feel the "effect" (asr) of this, which Tablighis understand to be "the passion of faith" (imaan ka jazba), which comes from feeling Allah's presence in one's words and in one's heart.

This process is understood as a movement from the tongue to the heart, from outter movement to inner dispositions, and back to outter practice (Mahmood 2001). Religion in this framework is understood not only as a distinct form of practice but also a set of affective qualities that sediment in the heart. Tablighi discourse is replete with 
phrases that mark the material nature of these affective virtues like pious fear, humility etc. Tablighis insist also that these qualities are something that Muslim receive from Allah through Islamic practice. "We have entered religion, but the religion has not entered us," Tablighis often say, implying that religion is something material that ones receives. Similarly, Tablighis make supplications like "God give us the strength" and "May God make our practice easy" after and during all activities, suggesting that the "effect" of practice is a gift that one acquires through dawat. When Tablighis speak about "growing" faith, they draw attention to its materiality. For instance, Tablighis will frequently compare one's faith of a non-practicing Muslim to a pebble in a stream, which, will necessarily be pushed in the direction of a stream. The faith of a Muslim who conducts his five daily prayers is like a boulder which stays firm for some time but will ultimately give way and be pushed along by the stream, while the faith of the Prophet's Companions (sahaba) was like a mountain.which forces the stream to move around itself. Dawat can make a Muslim's faith like that of the Companions.

As I have suggested in this section, Tablighis certainly understand dawat as a disciplinary practice. But, it is not enough simply to say that dawat is a disciplinary practice. We must also ask why it is that dawat in particular that creates the faith that is the condition for all other Islamic practices, and this requires further explication of the specific structure of dawat. What was is it that makes dawat the "mother of practices" and why was it unique in creating the requisite faith and certainty? In the next section, I answer these questions by exploring the specific ritual ideology that informs dawat. 


\section{RITUAL IDEOLOGY AND ETHICAL PERSONHOOD}

Dawat is understood as a ritual practice that is divinely given and prescribed. Its efficacy, Tablighis insist, depends on it being performed correctly, or, as they say, in the Prophet's way. Three interrelated feature of dawat stand out. First, the efficacy of dawat depends on it being conducted face-to-face, or as Tablighis refer to it "heart-to-heart" (dil se dil). Second, in order to be efficacious, dawat must be conducted with "purity of intentions" (ikhlas-e-niyaat), which means that it must not entail any "worldly" gain and must involve personal sacrifice. Third, dawat is not an "individual practice" (infiradi amal) but a "collective practice" (ijtimai amal), and therefore must be conducted as part of a collective for it to work. These three features of dawat are to borrow J.L. Austin's (1975) term the "felicity conditions" of dawat as a ritual practice. Let us briefly address each of these before exploring the specifics of dawat as a form of ritualized preaching.

The privileging of orality, as many scholars have argued, is a foundational premise of the Islamic tradition (Graham 1993; Messick 1993; Fisher and Abedi 1990). The Quran is, as I argued in Chapter 2, a recitational-text, and Islam stresses the material power of the Arabic words, which are understood as divinely given, not on the propositional content of the words alone. The notion that the voice is the necessary medium of dawat, then, draws on broader Islamic conceptions of the primacy of the human voice as the "unmediated" form of communication, unlike texts, which are seen as distant and mediated. Brinkley Messick (1993) has called this recitational logocentrism. The Tablighi claim that dawat must conducted face-to-face evokes the sense of "immediacy" and "directness" of orality over other forms of communication, both as it relates to other humans as well as to Allah (Eisenlohr 2010). According to Tablighis, 
when one is giving dawat, one is creating a "heart-to-heart" relationship between Muslims, and that the words are traveling "directly" both into the speaker's heart and into the listener's heart, thereby creating a relationship between them. This, Tablighis insist, is only possible through the human voice.

As Patrick Eisenlohr (2011) has argued, different religious traditions construct media technologies as more or less "direct" and "immediate" and more or less reliable as a medium of communication. The difference, then, between mediation and immediacy, is itself an ideological distinction. It's important to note here that while many Islamic movements have turned to mass mediated forms of communication, including radio, television and cassettes and internet, the Tablighi Jamaat remains committed to the faceto-face, oral nature of communication, which it sees as uniquely capable of communicating divine commands. While Tablighis also use cassette sermons, they insist that these sermons are only there to supplement what one does in the mosque and while giving dawat. They insist that one's physical presence is necessary for the both one's own and other people's spiritual transformation.

Tablighis say that what is crucial about dawat as an embodied practice is that it entails purity of intention (ikhlas-e-niyyat). Pure intentions here do not simply mean pure inner desire or commitment. Rather, the purity of intentions is tied to the fact that dawat requires the sacrifice of material resources or what Tablighis understand as sacrifice (qurbani). In order to be efficacious, dawat requires the sacrifice of three essential aspects of life: physical energy or life force (jaan), wealth (maal) and time (waqt). Each Tablighi is expected to commit his own resources during dawat, and it is in the sacrifice of these material resources that draws Allah's support. Because of this insistence on sacrifice, 
dawat requires leaving one's home and committing one's material resources, especially one's own body. One Tablighi explained the significance of embodied presence in the mosque to me:

When you are sitting in the mosque on the floor listening to a sermon, after a while you feel your knees start to hurt and then your back, and you start to move yourself into a comfortable position. You want to lie down or you want to get up and just go to the comfort of your home. But, just remember, it is when you start to feel this pain, that's when the heart opens up and religion (din) settles in your heart.

This quotation adequately captures an elaborate discourse on the importance of "hardship" (mashaqqat) in Tablighi discourse in which the benefits of dawat are explicitly tied to the physical and material difficulties of conducting it. Hence, dawat is seen as a form of sacrifice that yields divine rewards.

It is the body as well as an embodied voice that is understood as the necessary medium through which Allah's power is solicited. Practice, they say, "is the name of all that comes from the human body." There is nothing novel about this. This is exemplified in the mandatory Islamic prayer (namaaz/salat), which Muslims are to conduct five times a day, as well, where formalized recitation accompanies formalized bodily motions. So, the ritual ideology that shapes Tablighi understandings of dawat is familiar on to most Muslims. Tablighis say that conducting the mandatory prayer is the only the bare minimum that one must perform in the service of Allah. The mandatory prayer, as many Tablighis explained to me, is a "debt" (qarz) that must be repaid. One will have to answer for this debt on the Day of Judgment, and if one has missed any prayer, one will have to suffer the consequences of that, regardless of what other deeds one has performed in life. Tablighis say, "if these feet cannot take you from your home to the mosque, how will 
they take you from this world to the next?" But, if the mandatory prayer is a "debt" that must be paid, dawat is what builds a relationship with Allah, or, in the Tablighi idiom, dawat "connects one's self (zat) with God's self." This requires greater sacrifice that the mandatory prayer, and greater sacrifice also requires greater bodily discipline. It is not surprising, then, that so much Tablighis discourse focuses on the training of the body and the honing of the senses (Hirshkind 2006). The significance of discourse about bodily discipline in the Tablighi Jamaat cannot be overstated. As one senior Tablighi, Amin, explained in a sermon, "Islam is absorbed by the senses; the mouth; the ears; the eyes; the skin; but then kit must descend into the heart." He went on to explain, "We know in our minds but is has not yet descended into our hearts." Islam, he said, should "drip from the eyes" so that people can tell you are Muslim just by the way you manage your eyes. In this discourse, one finds clearly that dawat is a means of bodily discipline.

The relationship between bodily discipline and piety must be understood through broader Pakistani and Muslim understandings of personhood. In popular understandings, the person is comprised of three components, a lower self (nafs), the spirit (ruh), and reason (aql) (Kurin 1980). Spirit is understood to be a divine faculty, possessed by all animate beings: angels, humans, jinns and animals. Angels are unique because they are made of pure spirit. They are simply conduits for Allah's will and are incapable of breaking divine commandments. Animals also have a spirit, but their spirit is understood to be weak or relatively insignificant to their being. Animals mostly do as their base instincts tell them, thus animals are driven by their "lower self." Humans are comprised of both "spirit" and a "lower self," the former understood as the seat for animalistic desires and passions, including the passion for sex and other bodily needs. The "lower 
self' is not altogether bad; it is a necessary and even valued part of life, but it must be molded and brought in line with divine commandments (hukm) as they are embodied in revelation. Generally speaking, the spirit and lower self are contrasted as high/low, right/left, and cool/hot respectively. These are also, as we will see, relations of "inner" and "outer," for the lower self is contiguous with "the world," just as spirit is contiguous with "religion."

Humans are endowed with the moral faculty of reason (aql), which is located in the heart. Reason mediates between the two poles of being, spirit and self, angel and animal, high and low, transcendent and immanent. Kurin argues that reason is understood as part spirit and part lower self and has both cool and hot attributes. My Tablighi interlocutors unanimously agreed that reason, by itself, would lead humans towards their more base, animalistic desires. It was only through ritual practices that a person came to reason properly, and was able to distinguish right from wrong, truth from falsehood, divine commandment from the Devil's whispers. Reason is not regarded as a mental ability here. It has the potential to direct a person towards the spirit, the afterlife, towards truth and Allah, or away from these towards the lower self, the world, towards falsehood and the Devil. While reason is neither inherently good nor inherently bad, it will veer towards the latter if left to its own devices. It is for this reason that what is needed is bodily discipline that keeps a person oriented towards the good. This requires the purification of the heart.

The purification of the heart has been a central motif and philosophical concern of Sufi mystical thought and practice throughout Islamic history (see Schimmel 1975). Scholars of the Tablighi Jamaat remain divided over whether the Tablighi Jamaat retains 
aspects of Sufism or whether it is a "reform" movement based on the shariat, but these debates have less to do with the Tablighi Jamaat itself than with the divergent and conflicting definitions about how to delineate Sufism from reformist or scripturalist Islam (Gaborieu 2006, Masud 2000). Yet, as many scholars have demonstrated such stark contrasts are difficult to draw as both Sufi and scripturalists converge on the idea of the emulation of the Prophet (Woodward 1989: 66), and, as Mittermaier (2011) has recently noted, both Sufi and scriptualist orientations in Islam converge on the idea of the purification of the heart through disciplinary practice. In Tablighi cosmology, as in other Islamic piety movements (Hirshkind 2006), Islamic practice purifies the heart, and, in doing so, creates the conditions for divine presence. Dawat subordinates the lower self to the spirit, or rather, molds the lower self in line with the spirit, thus making a person capable of living according to Allah's will. Tablighis speak about this process as a person becoming "spiritual" (roohani), understood as assuming the qualities of angels, which is a total submission to Allah and an inability to disobey Allah's command.

For Tablighis, dawat is the necessary means for the purification of the heart, and the purification of the heart is the condition for the receiving all manner of divine rewards. Purification is achieved must fully by leaving one's home for an extended period of time and living and sleeping in mosques. I will return to the structure of this activity in the next section, but for now, it must be noted that dawat is modeled on the Islamic conception of pilgrimage to Mecca in which a Muslim is expected to do at least once in their life, in which Muslims assume great hardship and the sacrifice of resources in order to attain spiritual reward and renewal. The link between travel and purification is established in the story of the Night Journey in which the Prophet is escorted by the 
Archangel Gabriel from Mecca to Jerusalem and then through the seven heavens, where he then speaks directly to the Prophets of the Old and New Testament and to God himself, establishing his link to the Abrahamic tradition and connecting him directly to God. In this journey, the Prophet is also granted, as a gift, the form of the five mandatory prayers. Similarly, dawat is conceptualized as a form of travel in which one comes to recognize Allah's presence in one's life.

One might say, then, that the central purpose of dawat is the creation of ritualized bodies (see Bell 1992). But, Tablighis strongly stress the fact that this is not simply an individual acting on him or herself, and this brings us to the most crucial aspect of Tablighi conceptions of dawat. The efficacy of dawat is fundamentally tied to the fact that it is conducted with other Muslims who live together in the space of the mosque, distribute tasks and duties, and engage with one another in ways deemed Islamic. Tablighis insist that while many Islamic practices are "individual practices" (infiradi amal) that one can do on one's own, like daily recitation of the Quran, dawat is a "collective practice" (ijtimai amal) that must be conducted along with other Muslims. The importance of collective practice is fully captured in the oft-heard Tablighi maxim, "individual practice is like a speck while collective practice is a mountain," suggesting the reward and efficacy of the former is irrelevant compared to the latter. For Tablighis, the fact of living together in specific ways is no less an Islamic duty than the fact of living together as part of a community.

I will have much more to say about the intersection between ritual and sociality over the course of this ethnography. Indeed, drawing together ritual and sociality is the most distinct thing about the Tablighi Jamaat's piety movement, and from the perspective 
of Tablighis, the thing that differentiates them from all other Islamic forces in Pakistan and throughout the world. Tablighis say that through dawat, one comes to live with other Muslims as a proper Muslims and dawat creates a genuine Islamic community. For now, I would like to simply stress that dawat is understood as a form of collective work that produces not only pious individuals, but also a kind of pious sociality characterized by ethical and harmonious relations of care and concern. It is living and working together in a common Islamic project that is a necessary condition for the efficacy of dawat as a practice of ethical transformation.

In the next section, I turn to structure of dawat as a collective practice. While Tablighis insist that the efficacy of dawat derives from its divine origins, and because it is simply what Allah has willed it, this is hardly a sufficient explanation for an anthropologist. Drawing on an argument from theories of performance in anthropology, I argue that dawat's efficacy as a disciplinary practice actually derives from the fact that it is a dramatic enactment, and in being an enactment, it the draws scrutiny of other Muslims. By becoming the subject of scrutiny of others, one comes to live in ways that are in keeping with one's performance.

\section{PERFORMANCE, SINCERITY AND THE WORK OF CULTIVATION}

The features of dawat described above come together most fully in Tablighi dawat tours (gasht) in which Tablighis travel in groups of six to twelve people in order to preach the merits of Islam and draw Muslims to practice. Each week, Tablighis conduct one preaching tour in their local areas and one in another area in the city. Every month Tablighis conduct one three-day (sehroza) preaching tour that takes them outside the city, 
mostly to rural areas. Each year Tablighis are expected to travel on a 40-day trip (chilla) that takes them to various parts of the country. And, each Tablighi is expected to conduct at least one four-month dawat tour, understood as three consecutive chilla, in order to become what Tablighis call an "old companion” (purana saathi). This confers some authority, including the right and duty to become the leader (amir) of a preaching group. I will develop the significance of the distinction between old and new companions in light next chapter where I discuss the significance of hierarchy in the movement, but first, let us turn to the structure of dawat.

Dawat consists of three types of work; the tour (gasht) in which Tablighis walk around a neighborhood speaking to people, calling them to the mosque; the middle talk (darmiyani baat), which is conducted during the tour in which a person stays behind in the mosque where he speaks the praises of Allah while the others are on tour; and the reconvening at the mosque for mandatory prayers followed by the sermon (bayan). There are number of other pedagogical activities that serve to train new Tablighis that I will address later, but the above mentioned are all efforts to draw non-Tablighis to dawat, which is the ultimate goal of all Tablighi activity. All dawat is structured in this manner regardless of whether they are conducting it in their local areas or in distant travels. Dawat tours are either nestled between late afternoon (asr) prayers and evening prayers (maghrib) prayers or from evening prayers to nightly prayers (isha). The purpose of the traveling tour is to call Muslims to the mosque for prayers and to keep them there to listen to the sermon and to give them the formal invitation to join in dawat themselves, a practice called tashkeel, which literally means to "give form." 
When departing on a dawat tours, the leader will determine who will stay in the mosque to give the middle-talk and who will depart on the tour. The decision of who will give the sermon is, on traveling tour is decided earlier in the day, and when in one's own neighborhood, earlier in the week. The leader breaks the larger group into smaller units of between 3 and 5 people that will constitute the preaching group and direct them towards different locations in the neighborhood. Each group will select a speaker (mutakallim) who both be leading the group and will be communicating with nonTablighis. Before departing, the group will gather in a circle and one person will make supplications (dua) on behalf of the group, stating the intention of the group to do this in the service of Allah and for no other reason, much as one does in other Islamic rituals like the mandatory prayer, requesting that Allah help and guide in this endeavor.

Tablighis depart from the mosque in a single file, walking on the right side of the street, the side associated with purity, the spirit and the angels. The speaker will lead and the others will follow closely behind silently reciting in Arabic the third kalma or creedal statement called The Glorification: "Glory (is for) Allah. And all praises for Allah. And (there is) none worthy of worship except Allah. And Allah is the Greatest. And (there is) no power and no strength except from Allah, the Most High, the Most Great." When the group approaches a person, the leader will initiate the conversation with the standard Muslim greeting, "Assalamalaikum” accompanied by a handshake. After the exchange of a few pleasantries, the speaker will initiate dawat. The dawat frame is often keyed by a breath and a pause, followed by a reference to the addressees with an explicit statement about the duty of every Muslim to conduct dawat. This will be something along the lines of, "of course, you already know this, but this is our duty." This is especially common 
when the addressee is older, or a person of higher status more generally, thus diminishing the sense of superiority that might come with giving Islamic knowledge and charge of hubris (see Lambek 1993). Dawat work is a familiar enough sight in Pakistan that nonTablighis fully understand what is to follow, and, in most cases, they submit to the frame by bowing their heads, though of course this is not always the case. As the speaker begins to address the person, the others make a semi-circle around the speaker and the recipient and continue to silently recite the kalma. After the speaker has completed the preaching, he requests that the person accompany them to the mosque or come to the mosque for prayer times to listen to the sermon.

Dawat entails the intersection of two axes of speech, of ritual and ordinary speech, Arabic and Urdu, with the former being the vehicle for a vertical communication with God, while the latter being the vehicle for horizontal communication between human beings. In this sense, dawat brings together what Austin (1975) has described as the illocutionary or performative and perlocutionary or descriptive aspects of language. The Arabic performs the illocutionary function, which in Austin's formulation is speech meant to create an effect regardless of whether it is even heard by the addressee. It is meant to accomplish something rather than simply describe a state of affairs. The perlocutionary function, on the other hand, describes the world. In Urdu, the speaker describes the deplorable state of the world and invokes the authority of the Quran and Prophet to explain how Islam provides the means of escaping these problems. Tablighis say that when a person is giving dawat, Allah makes his tongue "move" and to give his words power, and makes the hearts of the listerner "soft" so that the words will settle in his heart. The efficacy of this ritualized preaching, for Tablighis, depends on the silent 
recitation of the Arabic creed, which solicits Allah's power and makes the words settle in the addressee's heart.

While others are on the tour, one person stays in the mosque to give the middletalk and sometimes, especially if the group is large, a few will stay back with him as listeners. He sits on the floor and begins to deliver a sermon-like explication of the virtues of dawat, structured by what Tablighi call the six-points: faith, mandatory-prayer, knowledge and remembrance, generosity towards Muslims, purity of intention, and importance of dawat. These six-points structure all of the performative discourses of Tablighis. The middle-talk is understood by Tablighis, like the recitation, to draw Muslims to the mosque by establishing a relationship with Allah. In practical terms, Tablighis explain, it is so that those who are present after the late afternoon prayer stay in the mosque to listen all the way through to evening prayer, and those who happen to come to the mosque will stay and listen till the evening prayer. But Tablighis insist that the middle talk must proceed whether anyone is present or not, whether anyone can hear or not, because Allah is listening, and it is Allah that draws Muslims to the mosque. Once again, what is significant is the performative aspect of language.

The image of Tablighis leaving the mosque in a single file, each reciting the creedal statement, while some stay in the mosque for the middle-talk, is understood by Tablighis to be a rope of ritualized words that is anchored in the mosque and pulls Muslims to the mosque for the mandatory prayer, and crucially, to the sermon (bayan). After the first part of the mandatory prayers, one Tablighi rises to announce that there will be a sermon (bayan) after the prayers. When the mandatory prayer finishes, 
Tablighis quickly gather to make a semi-circle around the speaker to indicate to others that the sermon is beginning, and speaker stands and begins the sermon.

The sermon deserves special treatment in this analysis for the whole dawat process intended to draw Muslims to the mosque culminates in this event, and it is seen as doing the real transformative work by putting passion and desire in the hearts of others as well as in the speaker himself. Seated on the floor of the mosque, Tablighis huddle closely together, ideally in a kneeling position with one's head down, a manner similar to the "resting" (qiam) position during the mandatory prayers, a posture that clearly indicates total submission. Tablighis have elaborate discourses about the ethics of listening during sermons. They stress that listeners focus intensely on the words, absorbing them into the heart, rather than being distracted by "the world," a fact that is repeatedly stressed in performance of the sermon itself. Tablighis will say things like, "make your whole body an ear!" in the performance, highlighting how the sermon is itself an instruction on how to be good listener. There is much to say about this discourse about the ethics of listening that I will develop in the next chapter, but here I only want to stress that the Tablighis believe that the listening to the sermon "opens the heart" and allows "faith" and "passion" to settle in the heart.

The sermon is structured by the six-points, though for a novice, it is not always clear where one point ends and another begins. Part of becoming an old companion is learning how to identify each of the six-points in the flow of the sermon. Some speakers will stress some points, while others develop other points, but the purpose of the sermon is to render in dramatic form the significance of each of these points by drawing on a field of knowledge about the lives, sayings and experiences of all the Prophets, especially 
the Prophet Muhammad and his Companions, as well as various Islamic scholars, elders and other authoritative figures of the past. Much of this knowledge is drawn from a wide array of Islamic textual sources, acquired either through reading, or acquired through listening and time spent in the Tablighi Jamaat. It is the richness of this discourse and the rhetorical flair and embellishment with which it is dramatically rendered that gives the Tablighi Jamaat its distinct character, and it is the desire to acquire the ability to speak with such force and conviction that draws many people to the Tablighi movement.

I cannot deal with the richness of this discourse here, though I hope to draw from both the content of the middle-talk and sermons over the course of this dissertation. For now, I want to focus on the general effort of the sermon to create in the listener a sense of moral degeneration, a disjuncture between a sacred past of Muslim unity and flourishing and the deplorable state of Muslims in the present. It is the principle aim of Tablighi sermons to create this disjuncture between then and now and provide the opportunity for the listener to rectify this by recreating the past in the present by joining the Tablighi movement. One can think about this temporal disjuncture as commensurate with the distinction between the spirit and the lower self, where the past is "spiritual" while the present is overcome by desires of the lower self.

This moral disjuncture is also mapped onto spatial distinctions as well, in particular the distinction between the purity of the world inside the mosque and the impurity of the world outside the mosque. This is arguably one of the most repeated claims inside the Tablighi Jamaat that the mosque is a place where the angels reside, and where one finds peace and comfort. Because religion is absorbed through the senses, spending time in the mosque is itself purifying. Spending time outside the mosque, in the 
world, however, is corrupting. In sermons, as in Tablighi discourse more generally, the contrast that is drawn is usually between the mosque and the market, the former being the place of the spirit:

Being in the mosque is like being in a perfume shop...you absorb all the smells. Isn't that different from being in a fish market? . . . The mosque is a space of angels. .. . Do you know what angels special characteristic is? It is that they will never disobey Allah's direction. If Allah tells them to stay in prostration, they will do this for all eternity. This is why we must spend time in the mosque, so that we can learn to obey Allah.

This contrast between mosque as a space of the spirit and spiritual renewal and the market as a place of the desires of the 'lower self' is a well-developed theme. The market is understood as a place that ignites the passions for "the world," while the mosque induces passions for religion. In this quote, it is clear that one absorbs the qualities of the mosque through the senses, just as one absorbs the qualities of the market, and this will make one not only obedient to Allah, but that such obedience is itself pleasurable to the senses, unlike the market, which is repugnant.

What one finds in Tablighis sermons is the elaboration of a moral disjuncture in both time (then and now) and space (mosque and market). It is the purpose of the sermons not only to highlight this moral disjuncture, but also to provide a solution, and that solution is dawat, which recreates the sacralized past in the present and keeps Muslims inside the sacred space of the mosque. Although all the principles of the sixpoints are important, it is the first principle, faith, and the last principle, dawat, which really enclose Tablighi cosmology. Faith, Tablighis says, is the conviction that "everything comes from Allah and nothing comes from anyone other than Allah" and "it is through the Prophet's ways that one acquires success in both this world and the next, 
and there is only ruin in the ways of others." Dawat is the necessary condition for faith, and because the Prophet is the "seal of the Prophets" and because no other Prophet will be sent, Tablighis say, the responsibility to spread Islam has now fallen on every individual Muslim. These principles are connected with references to the hardships the Prophet experienced spreading the Islamic faith, and the need to live by the Prophet's example if Muslims truly want to embody the faith.

The sermon is closed by what can be translated as "the invitation" (tashkeel), a word that literally translates as to give shape or form or to "create." At the end of the sermon, another Tablighi holding a pen and a pad rises and joins the sermon giver, who then proceeds to ask who will commit to a specified period or dawat, starting with the longest ( 7 months) to the shortest (3 days). Often this requires repeating a few times, and interlaced with exhortations and examples drawn from the life of the Prophet and his Companions, or a detailing of the merits and benefits of dawat. Regardless of how many times a Tablighi has voiced his commitment, Tablighis will stand and voice this commitment because, it is often said, that "to make one's intention known is itself a meritorious deed." New comers will also occasionally stand and register their commitment as well, which will then be tallied in the notepad. If the purpose of the sermon is to create a sense of moral disjuncture and to posit a remedy to that moral disjuncture through dawat, then the invitation is about asking people to make a public commitment.

This public commitment is crucial. For Tablighis, it was precisely this soliciting of a public commitment that differentiated the Tablighi Jamaat from other Islamic movements. The difference was captured in the oft-heard phrase, "the difference between 
'conveying' (tabligh) and giving speeches (taqreer) is the invitation (tashkeel)." This statement implies that the Tablighi Jamaat, unlike other Islamic groups, is not merely about "talk" but about "practice." The centrality of the invitation to the Tablighi Jamaat's self-understanding provides a key into how dawat functions as a disciplinary practice. I have already argued that Tablighis see dawat as practice that purifies the heart, but now we are in a better position to understand precisely how they understand this to happen.

The entire process of dawat, especially its culmination in a ritualized form of the invitation bears striking resemblance to what Webb Keane has described as the "creed paradigm" (2007: 67 -72). Creeds, according to Keane, are "an explicit statement of religious tenets and the norms for its verbal performance," and are crucial for evangelizing religions like Christianity and Islam because they condense complex theological arguments and give them a definite semiotic form, which allows them to circulate across many contexts. This is precisely the function of the six-points, to condense the cosmology into an easily learnable "object." What is crucial here is that creeds are not merely statements of belief but are "attached to a performative of assent," which is a public registering of one's commitment to a religious order (2007: 70). Indeed, this is precisely how the invitation functions at the end of sermons, where people stand to give assent to a religious order by making a public commitment to dawat. It is by taking this public stance that one makes oneself responsible for one's own words and for one's own beliefs. Hence, the Tablighi refrain "we know but we do not do" or the gap between knowledge and practice is overcome because once one stands to attest one's commitment, one is compelled also to live in its terms. It is by assuming responsibility for one's performance to a public that the gap between knowledge and practice is filled. 
As Keane has so aptly argued, the creed paradigm is underpinned by the norm of sincerity, a point that applies as much to Islam as it does to Christianity. A sincere subject is one whose outer performance is aligned with his inner self, a person who is true to his words and actions. The most deplorable person in Tablighi discourse is the "hypocrite" (munafiq), which is a Muslim who shows outter signs of piety but has no inner faith. This person will be condemned to the deepest pits of hell. Yet, while a person should be conducting dawat sincerely, Tablighis also say that a sincere subject arises through dawat itself because dawat produces the very faith that one extols in speech and action. This is why a Muslim must do dawat regardless of whether he feels the faith or not. Hence, unlike Calvinists, who treat ritual as antithetical to the sincerity of the subject, here sincerity is both a condition for and the outcome of dawat. In this sense, dawat is recursive and disciplinary (Mahmood 2001).

I want to stress here that Tablighis are self-aware that efficacy of Islamic performance has to do with the fact that they force a person to make a public commitment and thus take responsibility for fulfilling the terms of that commitment. While a dawat tour, the leader or amir of our group, Irfan, explained to us the significance of dawat as a public commitment, "Now we are no longer who we were. Now we will be known as Tablighis. Now all of our deeds (amaal) will be scrutinized from the way we eat, to the way we sleep, to how we treat each other. Now we must be meticulous in upholding these good deeds because we are now from the jamaat." In other words, Tablighis believe that by embodying in speech and actions the signs of the Prophet, they will be expected to live according to the ethical entailments of these signs. There is a slight but crucial difference herer from the Calvinists that Keane describes. If Calvinists believe the creedal 
statement is an expression of belief, Tablighis work backwards from this proposition to show that it is the performance of Islam itself that creates inner dispositions like faith. This is what makes dawat, as a performance, a powerful force for self-transformation.

The idea that by enacting Islamic signs one comes to embody the virtues that inhere in them is extended to all manner of bodily signs like growing beards and wearing skull caps, as well as embodied practices like modes of sitting, eating, speaking and sleeping and any number of other activities. Take, for instance, the explanation one Tablighi gave for the importance of the beard in Islam:

The beard keeps me from all my sins. When I first kept the beard, my friends made fun of me, and said that I would drive away all the girls. I found that funny, but I soon realized that, yes, that's the whole point! A girl sees me with a beard and she thinks this person is "religious" and she is repelled. At first, I felt awkward with the beard, but every time I wanted to do something bad, I would think that people look at me and they say, this person is religious and look what he is doing, and when you know that, then you develop concern in your heart, and so you do the right thing. The beards helps me focus on good deeds, and when people seeing you do good deeds, then they too want to follow your example.

At the heart of this statement is the notion that signs of Islamic piety signal a public commitment, and in doing so, force one to take responsibility for one's actions. This is how they discipline the performer. My argument, then, is in keeping with position elaborated by Asad (1993), Mahmood (2005) and Hirshkind (2006) who argue that Islamic practice is a means of discipline, but I add here the point that practice disciplines the practitioner precisely because it communicates to others something about the person's interiority. Islamic symbols say that the person is the bearer of dispositions of piety, and therefore makes the person responsible for the social expectations of that symbol. The performance, then, creates a kind of communicative relationship between people through 
Islamic signs, which compel both addresser and addressee to live in terms of the performance.

In the Tablighi Jamaat, these symbols of piety, all understood as the ways of the Prophet, come in the form of words, bodily actions, and material objects like beards and clothing, and can be understood through Charles Pierce's (1955) tripartite division of signs. According to Pierce, there are three kinds signs: a symbol, which posits a conventional relationship between signified and signified, like the relationship between words and meanings; icons which posit a physical resemblance between the signifier and the signified, like the relationship between a map and a place; and an index, which posits a relationship between a signifier and signified that is not arbitrary but definite and causal, like the relationship between smoke and fire. In dawat, the person becomes an icon of the Prophet, resembling as a symbol the Prophet's manner and dress. This iconicity is also indexical in that the Prophet, the exemplary human being, had all the inner qualities that his outer performance implied, or that there was no disjuncture between outer and inner. Hence, outer signs are indexically linked to inner qualities like faith such that someone who embodies these symbols must also have faith by causal necessity. Yet, Tablighis are aware and fully acknowledge that the relationship between outer sign and inner disposition is also, potentially, arbitrary, that outer signs do not by necessity produce inner dispositions, hence the central importance of the much reviled figure of the hypocrite. This hypocrite represents here the threat posed by the arbitrariness of the relationship outer signs and inner dispositions, between signifier and signified. Tablighis insist that even if this relationship is initially arbitrary, over time and through repetition, outer practice will produce the inner disposition of faith. In semiotic 
terms, iconicity is converted to indexicality. Through performance, one comes to embody the virtues of the Prophet.

This dialogical or intersubjective aspect of Islamic symbols is crucial because it means that ethical self-cultivation and discipline is not simply an individual acting on him or herself, but requires the participation of others. Tablighis argue that Islamic symbols have disciplinary power because they bring Muslims into a relationship with one another, and not any relationship, but a relationship based on "the good" (achei pei). The theory of ritual as a disciplinary practice might benefit, then, from one crucial aspect of older theories of performance, which is that performances is a communicative relationship between the performer and the audience, the addresser and the addressee. Performance, as Richard Bauman defines it, is "a mode of spoken verbal communication [that] consists in the assumption of responsibility to an audience for a display of communicative competence" (Bauman 1977: 11). Dawat includes "verbal communication" as well as nonverbal communication, but the point stands that it functions because it draws the gaze of others to the self. Performance opens oneself up to scrutiny not only for the propositional content of communication, but also for its formal characteristics of how the performance is executed. I have described some of these formal features of the tour, the middle talk, and the sermon, but Tablighis recognize all aspects of life including like eating, sleeping, walking and talking as performance in the context of dawat. As Irfan's quotation above suggested, in the context of dawat, even these everyday aspects of life come under scrutiny and therefore compel a person to live up to the model of an ethical life. 
This is a crucial launching point for this dissertation. As I will show the next chapter, the performance of dawat creates relationships which Tablighi understand to be built on "the good," and it is these relationships that create the possibility for any individual Tablighi to live an Islamic life. If there is something distinct about the Tablighi Jamaat it is that it is a space where ethical relationships, rather than simply ethical selves, are fashioned. The Tablighi Jamaat is a space of performance where one becomes a producer of Islamic iconicity, a process that opens oneself up to the judgment of others, and, because of the norm of sincerity, compels one to live in terms of that public commitment. These others include fellow Tablighis as well as non-Tablighis. By placing one in a relationship to others, making one responsible to the scrutiny of others, one becomes a pious subject. This is how dawat creates the conditions for the ethical life. 


\section{CHAPTER 4 \\ PIETY AS ETHICAL RELATEDNESS IN THE TABLIGH JAMAAT}

When I began my research, my assumption was that Tablighis were invested in preaching to all Muslims, and I would have little trouble getting them to discuss religious matters with me, a Muslim who they clearly had an interest in drawing into the movement. I figured that I would be there project and they would be mine, and that would be incentive enough for them to talk to me, and yet, I found myself stifled at every turn. It was not that I could not get them to speak to me. It was that I could not get them to tell me anything beyond the virtues of dawat. I found myself constantly trying to get beyond or behind these formulaic statements in the hope of finding what I understood to be real data about their lives and motivations, when my interlocutors insisted that what I need to do was understand what they were saying through the heart. When I explained to Tablighis that I was conducting research in order to write a book, they recoiled at the idea, insisting that Islam is learned by doing and that only by doing dawat would I come to understand. When I tried to shift the focus of the conversation to them and their own history in the movement, they almost always withdrew, making it clear that doing dawat was not the same as talking about one's own life and history. Hazrat often repeated the refrain, "Dawat is not the name of talk. Dawat is the name of a practice (amal)."

My research produced a vexing paradox: I was, on the one hand, clearly an object of preaching, a Muslim in need of instruction who was making himself available for instruction, yet I could not get Tablighis to speak openly to me about their own experiences. This was a source of great anxiety in my research as I worried I would not be able to collect life narratives or even to find out much about their lives. Overtime I managed to build relationships, but even then much of what even my closest interlocutors 
said to me was quite formulaic and drawn from stock phrases that I had heard many times before. They told me that what I needed was to "listen" properly, by which they meant through the heart and only then would I come to understand what I was so desperately trying to understand. Many Tablighis told me that what I needed to do was simply do the four-month tour (chaar maheenei) and then I would understand everything and I would no longer need to ask anyone any questions. Many Tablighis said that my "research" would not only fail to bring me to the truth of Islam, it could also lead me away from the truth. My research was not only detrimental to me, but from the clear avoidance of me by many Tablighis, one might say it was detrimental to them as well and generally disruptive to the proper order of things. What I needed was to become a proper listener, something my research kept me from becoming.

My aim in this chapter is to draw on my own experience as a novice at dawat in order to identify its cultural and ethical underpinnings. What exactly, I ask, is it that qualifies dawat as a "practice" as opposed to "mere talk" or even "research." I argue that dawat entails an ethics of relatedness in which a person must submit to the authority of others, which I was failing to do because of my own ethnographic commitments. I argue that the Tablighi Jamaat congregation is a space in which one begins as a listener and gradually becomes a speaker, which is understood as an ascent up a religious hierarchy. The hierarchical relationship between listeners and speakers is the central organizing principle of the Tablighi Jamaat. Tablighis understand this relationship to be an Islamic ideal because it is modelled on the relationship between the Prophet and his Companions (sahaba). An ethical person in this framework is one who lives according to his place in this religious hierarchy. For a novice, this means being a listener and allowing oneself to 
being "acted upon" by those more pious than oneself. I argue that it is this ethical relationship between listeners and speakers that, for Tablighis, gives their congregation its Islamic cast. Moreover, I show how my own "research" presumed certain egalitarian comitments of its own, which rendered me a rather poor listener and thus a poor Islamic subject.

\section{DAWAT AS THE PROPHET'S WAY}

Every Thursday evening, I would accompany my Tablighi friends to the grand mosque complex (markaz), the Madni mosque, where thousands if not tens of thousands of Tablighis would congregate shortly before evening prayers and stay till the morning prayers on Friday. The Madni mosque is located in the middle-class area of Azizabad. Everyone in Karachi knows of this area because it is also where the headquarters of the MQM political party, the most powerful political party in the city representing the majority Muhajir population is located (see introduction). The Madni mosque has an open courtyard that stretches for several blocks. It can accomodate anywhere between 20,000 to 50,000 worshippers. Built in the early 1990 s, the Madni mosque partially replaced the other grand mosque complex in Karachi, the Makki mosque, which is considerably smaller than Madni masjid. Makki mosque still serves as the administrative center of the Tablighi Jamaat in Karachi, and the Elders will hold a weekly consultation (mashwarra) there with the heads of each mosque, and will occasionally summon Tablighis from certain districts for a more focused consultation. Yet, for all intents and purposes, it is the Madni mosque that serves as the single unifying space where the entire Tablighi congregation of Karachi will come together on a weekly basis. 
On Thursday evenings, thousands if not tens of thousands of Tablighis flow through the six gates of the Madni mosque. Each Tablighis is dressed identically in his shalwar-kameez. Each Tablighi keeps a long, flowing beard, wears a Muslim skullcap and wears his shalwar or pant legs raised above the ankles, in the image of the Prophet. Thousands of motorcycles are stacked, one on top of the other in a specially designated street on the southern side of the mosque. The image of these thousands of motorcycles crammed together reveals the something about the lower-middle-class composition of the Tablighi movement in Karachi. It is difficult not to be overwhelmed at the sight of thousands upon thousands of worshippers flowing through the gates of the Madni mosque. Thursday evening is called "the night of Friday" (shab-e-jummah) is understood as a "big night," a night designated for worship. From early evening onwards, Tablighis listen to sermons given the Elders of the movement. They worship late into the night, and then sleep on the marble floors of the courtyard, after which they wake up early in in order to pray and listen to sermons before they return home to prepare for Friday prayers in their neighborhood mosque. Shab-e-Jummah is an especially meritorious time. The Prophet, Tablighis noted, usually spent all of Thursday night in worship, and many insisted that Allah accepts all prayers in the period between Thursday night and Friday afternoon prayers. Others suggested that one could expiate all sins if one worshipped through the night. Tablighis also stressed the importance of praying in large congregations with other pious Muslim. They claimed that in any congregation, Allah grants the merit (sawaab) earned by the most pious to the entire congregation, and since the Elders of the Tablighi Jamaat were exemplary Muslims, shab-e-jummah was an unparalleled opportunity to achieve merit. Tablighis sit and sleep in an area designated 
for their respective mosque congregations (jamaat) and in an area of the mosque designated by areas of the city. An individual's identity is directly connected to the mosque to which he belongs, and this becomes most clear at dinner. Each individual contributes to their mosque fund for dinner, and each mosque congregation makes their own arrangements, bringing with them food, plates, some silverware, a tea kettle, and a long mat (dastarwkhwan) around which all the members of the congregation sit to eat.

Shab-e-Jummah was an extremely important for most of the Tablighis I knew and they would try their best not to miss it. It was important for Tablighis to be "seen" by others since it revealed ones' commitment to dawat and showed one's willingness to sacrifice for it. Not being seen, on the other hand, meant that one failed to recognize the value of practice. If someone missed shab-e-jummah once they became the subject of mild and friendly teasing, which could be a source of embarrassment, but when someone missed shab-e-jummahntwice or more in a row without a legitimate excuse, they became a subject of concern. This meant that some effort had to be exerted on them to draw them back and many of my Tablighi friends did not want to be seen as someone who needed others to draw them to the mosque. In other words, one's status in the mosque congregation was intimately bound up with one's presence at shab-e-jummah. Yet, despite the stress my interlocutors placed on the merits of practice at shab-e-jummah, many Tablighis see it as a time to socialize with one's friends, joke around, and discuss other everyday matters. This made shab-e-jummah the best site for me to pursue my research, because, it was one of those rare spaces where people were engaged with each other in matters not exclusively about ritual practice. 
My presence at shab-e-jummah was always a little awkward as I did not belong to any specific mosque. I was treated as a "guest" of Hazrat and had been adopted into the Al-Aqsa mosque by virtue of my association with Hazrat. As I explained in the introduction, Hazrat was an Elder of the movement who sat on the city and national council (shura), so he was an immensely influential Tablighi. He was also the spiritual father for the Tablighis of Al-Aqsa mosque. While I spent most of my time with Al-Aqsa Tablighis, I was not attached to any of the mosque congregations in which I spent time, and I moved between mosques in order to talk to whoever was willing to talk to me. I did not contribute to mosque funds for either Al-Aqsa or Talha's mosque, Mujahid, with which I had also become closely acquainted. When I tried to contribute to mosque funds, I was told it was unnecessary and that I was a "guest" (mehman). Moreover, I was not assigned tasks that other Tablighis were as part of a rotational cycle of what Tablighis call "service" (khidmat). Each shab-e-jummah, someone is responsible for making arrangements for dinner and for breakfast. This entails making all the arrangements for the group's food, laying out the eating mat, setting the plates, arranging for water, and then cleaning up after everyone has finished. The "service" is believed to create humility (khushu) in a person and is therefore a crucial practice. Yet, despite the fact that I was not a part of a mosque congregation, I was often invited into the living quarters of the Elders to sit and eat with Hazrat. Being inside the living quarters of the Elders was seen as a great honor and conferred status to Tablighis, and the fact that I was often invited to eat with Hazrat and even to rest there if I needed, made many people envious of my position. I draw attention to this background because it was my strange position as Hazrat's "guest" that shaped how others responded to to me. Shab-e-jummah brought out my 
anomalous place inside the Tablighi congregation more than any other aspect of the movement. In the neighborhood mosque, I would attend a weekly sermon given by Hazrat, following which I would go to Hazrat's spiritual house. I would join one of these mosques, usually Al-Aqsa, for their weekly dawat tour, and I would intermittently attend nightly education sessions (taeleem), which involved reading aloud from the central text of the Tablighi movement, the Fazail-e-amal (Virtues of Practice). From the perspective of Tablighis, my participation was haphazard at best, and although people encouraged me to be more regular, haphazard practice was not itself unusual. Many young people would trickle in and out of Tablighi events without becoming fully committed Tablighis, and so, I was seen as simply being one of those people. Those who knew me well understood that I was doing "research," but they also knew of my relationship to Hazrat through Talha, and they knew that if Hazrat had given tacit approval to my presence in the spiritual house and in his quarters, then it was hardly their place to object.

It was at shab-e-jumma that my unusual situation as a "guest" became complicated because I did not know who to sit with, who to eat with, or where to sleep. Of course, I was not the only who moved between spaces. Indeed, it seemed to me that one of the remarkable things about shab-e-jumma was that it provided the opportunity to connect with friends and family who one might not otherwise see during the week. What was unique about my particular situation was that I lacked identification with a mosque and a neighborhood. When strangers asked to which mosque I belonged, I would explain that I lived in the Clifton area but that I was not at shab-e-jumma with a mosque from my area. Normally, I would explain that I had accompanied friends because I was interested in dawat and I wanted to understand it better. This is not unusual since many people, like 
me, began dawat by accompanying their friends and family members. Strangers assumed that I was following a standard path, but those that saw me regularly wondered why exactly I was part of the Al-Aqsa congregation.

My anomalous situation was a source of concern for some of the Al-Aqsa Tablighis. Those who I knew from Hazrat's spiritual house, especially the ones who were close to Talha, treated me warmly and mostly like a friend. Most of them seemed to believe that Hazrat had a plan for me, and that overtime I would be brought on the right path through my participation in dawat and through my relationship with Hazrat. But, there were many others who did not understand what exactly I was doing at the Al-Aqsa mosque if I lived on the other side of town, in Clifton, and many seemed suspicious of my presence and reluctant to engage with me at all. It was in shab-e-jumma that my sense of not "belonging" was most marked. What was at stake in this was brought to my attention one hot and humid August evening at shab-e-jumma. I was sitting with a few younger Tablighis after dinner. The conversation was banal. Usman, a polite and softspoken young man in his early 20 s who spent a great deal of time at the spiritual house, was describing to me how some customers at his mobile phone shop in the Electronics Market come in to trade their phones for new ones almost every month, and how, phones had become an obsession for young people. In the middle of the conversation, a young boy came to Usman and told him that Amin bhai (bhai being the title for older brother) was calling him. Usman promptly went over and kneeled next to him. Amin bhai was a slender man with a small features and a large forehead. He was very well respected in the Al-Aqsa mosque and would often be invited to the quarters of the Elders. He was considered an exemplary Tablighi, who possessed an unusual level of piety (taqwa) and 
faithfulness (iman). Amin bhai had recently returned from a seven-month tour, considered the second highest level of commitment after the one-year tour, which took him to numerous countries in Africa. He and I had met briefly at the annual congregation in Raiwind from which he departed on his extended tour. It was clear over those few days that Amin bhai was a pivotal person inside the Al-Aqsa mosque and acted as a representative of their mosque at the national congregation. Since he returned a few months ago, he and I had become casually acquainted. It was apparent even in our few conversations that Amin bhai found my presence at Al-Aqsa to be odd and even unsettling, and I suspect that he had consulted others about what exactly I was doing there. He was always polite and would often greet me, but the sense he left me with was that he did not feel like I really should have been there, though he understood that Hazrat had wanted me around and of course the mosque was a place where all were welcome. I was always worried that Amin bhai would create barriers to my research and possibly even have told others explicitly not to talk to me about matters. As I walked over to Amin bhai, these were the thoughts that raced through my head.

“Come, come, Arsalan. Please sit down,” Amin bhai said. "Assalamalaikum, Amin bhai. How are you?" "Waleikum asalaam, well by Allah's mercy. MashAllah, I'm very pleased to see you've been coming to shab-e-jumma regularly." I nodded. "It's nice," I explained. "I get to meet new people and get to talk to people and it helps me better understand what dawat is about. I am learning a great deal." Amin bhai smiled and nodded. "Dawat is our purpose in life," he said. I nodded in affirmation. Amin bhai and I had never formally discussed my research, but what he said next made it very clear that he knew something about what I was doing at shab-e-jumma. Shab-e-jummah is a very 
"spiritual space" (roohani mahol), he explained, and just being here helps one become a better Muslim. "Islam is absorbed by the senses," Amin bhai explained, "so just being here helps one absorb religion, but then, it must descend into the heart." Amin bhai went on to explain that even though it is a powerful space, one should not just come here and expect it to transform one automatically. One must put the effort (mehnat) in to acquire the results. Again, I nodded in affirmation to things that I had heard frequently. "Without doubt," I said. The issue is, he noted, clearly alluding to my research, that Islam is not a "bookish religion" (kitabi mazhab) but a "religion of practice" (amali mazhab). Religion does not settle in your heart only by reading and writing about Islam, and it certainly does not settle in your heart through "talk," he explained. Amin bhai launched into a story about a professor he encountered who was very knowledgeable about Islam. This professor, he explained, knew the Quran inside out and one could ask him anything about what was in the Quran and he would tell you exactly which chapter (sipara) of the Quran it was in. It was hard to believe, Amin bhai noted, that this man had so much knowledge ('ilm) because he did not do any of his practices (amal). "See, we know this in our minds (zehn) but it has not descended into the heart." Amin bhai, then, described how even though this professor had all the knowledge in the world, he was always "troubled" (pareishan) and never had any "peace" (sukoon). He was always running around seeking new knowledge, which is why he seemed to know so much, but this knowledge was “empty." "This knowledge did not have Allah's vitality (barakat) and therefore it never satisfied his yearning, and the more he acquired the more troubled he became." Amin bhai explained that when one is troubled, one becomes incapable of living one's life in a religious way (dini tariqa). After explaining this Amin bhai, as if speaking to a child, said 
I was now free to go back to the others. I nodeed, smiled and returned to my place with the others.

I had my own interpretations about what Amin bhai was trying to communicate to me by drawing this parallel between me and the professor, but I figured it would be better to consult someone, so I decided to ask my friend, Shahzaib. Shahzaib and I had gone on a ten-day preaching tour together that took us from Karachi to Multan and from there to the three day national congregation (ijtima) in Raiwind, where I also met Amin bhai. This was Shahzaib's first preaching tour and although he only intended to do a ten-day tour (aishira), the others had managed to convince him to complete a forty-day tour (chilla) with them. Since then, Shahzaib had become an active presence in the Al-Aqsa mosque. Shahzaib and I were quite close. He was my age, 31, and had gone to college in North Carolina. He spoke English fluently, and was always eager to speak to me in English. He saw our relationship as an opportunity to speak English, which the others at Al-Aqsa did not speak very well. We also spoke at length about what his life was like before dawat. He had given up many of his friendships because his friends were not very religious (dindaar), and as with Talha, this seemed to weigh heavily on him. This was largely the basis of our friendship.

When I told Shahzaib what Amin bhai had said, he emphatically agreed. "Don't take it wrongly, Arsalan. Amin bhai is only showing concern (fikr) for you," he exclaimed. Shahzaib noted that Amin bhai was only trying to guide me to the right path and this was his duty. I asked him what he thought Amin bhai was trying to communicate to me, and Shahzaib explained that Amin bhai knows that you have been coming to the mosque and Hazrat's spiritual house for some time now, and he just wants to help you 
"come to religion in the proper manner" (din pei sahi ajao). Shahzaib noted that while I was spending time in the mosque, it was not having the "effect" (asr) that it should be having. The implication here was that I was not cultivating "faith" and "certainty" that one would otherwise expect from being involved in dawat. What Shahzaib said next made this abundantly clear. "Look, you and I have been coming to the mosque for around the same time, but you are distracted by your research, which is why dawat has not had the same effect (asr) on you." This was a more honest answer than I would've received from most other Tablighis, who generally refrain from directly commenting on another person's faith. Tablighis say that what is in one's heart is "hidden" from view and is knowable only to Allah, but Shahzaib felt we were close enough for this level of honesty. When I asked Shahzaib why he thinks that this space has not had the proper effect on me, he explained that it was because I was "treating religion like it is research (tahqiqat)." When I asked what he meant, Shahzaib explained that while I come to the mosque and the spiritual house, and I have made friendships, like with him and with Talha, my research is always dragging me "here and there." "You are not part of the "everyday ties" (rozana ka jor) of our mosque or of your own mosque," Shahzaib said. "This means that although you come to the mosque, and you even do some practices, you are not following the Prophet's way (tariqa)."

Shahzaib had a better sense than others about what I had meant when I said I was conducting "research." He had studied textile design in the US, and he seemed to understand that there was something like an academic study of religion, but like the others, he regarded this as a distraction at best and a subversion of Islam at worst. Yet, like many others, including both Talha and Hazrat, Shahzaib remained faithful that I 
would gradually be transformed, and possibly even abandon my research, and just commit to dawat. There is much to say about this gap between "research" as a practice and what Tablighis themselves wanted me to do.Amin bhai's statement that Islam is not a "book religion" but a "religion of practice" confirms what is now well established in the anthropology of Islam: the Islamic tradition is not imagined as a set of propositional belief statements to be grasped by the mind but a set of embodied disciplinary practices that mold a person into an ethical subject (see Asad 1993, 2003; Mahmood 2005; Hirshkind 2006). But, in both Amin bhai and Shahzaib's explanations, it is clear that efficacy of Islamic practice was far from automatic. Indeed, I, too, was conducting most of the practices that Tablighis deemed correct. I spent a considerable amount of time in mosques doing precisely what Tablighis were doing.

As a Muslim, and someone who had spent much of his life praying in mosques, I had few qualms about conducting the mandatory prayers. Like Tablighis, I regularly listened to sermons, both the ones that were given at Al-Aqsa and at Madni Masjid, and I even devoted a considerable amount of time to listening to the sermons of the Elders that circulated on cd. Overtime, I had learned how to speak about the content of these sermons in ways comparable, and sometimes even better, than many Tablighis I had come to know. And, Tablighis were invested in acquiring this knowledge as a guide for how they should live their lives, so this was a valuable trait to them. I began to ask what exactly it was about my "practice" that failed to create faith. Why the failure of embodiment if I spent so much time in the mosque engaged in what Tablighis deemed exalted practices of the Prophet? The explicit discourse of Tablighis, if taken at face value, makes it seem like the process of embodiment is fairly automatic. As they say, "if 
one spends time in a perfume shop, one is bound to come out smelling like perfume." Tablighis were rather certain about the efficacy of dawat as a practice, and they insisted that living in a religious space (mahol) would gradually fashion one into a virtuous practitioner. Why exactly was if failing to have this affect on me?

These are questions that emerged both for Tablighis and for me because of the unique nature of my presence in the Tablighi congregation, a presence that obviously was shaped by my research interests. Overtime, however, I realized that these questions were actually central to Tablighi discourse. In other words, although "official” Tablighi discourse stressed that spending time in the Tabighi congregation would automatically have an effect, like perfume in a perfume shop, Tablighis understood that this was not actually the case. Indeed, as I came to learn, the efficacy of dawat required not just spending time in the mosque, even if one is technically involved in practice, but actually building the right kinds of relationships, relationships built on "the good" (achei pei). Shahzaib's claim that I was not embodying the virtues because my practice was "here and there" also implied that I was not creating the kinds of ties that properly inhered in dawat. In other words, what Shahzaib was saying was that although I spent time in the mosque, and although I listened to sermons, I was not cultivating the kinds of ethical relationships that one cultivates in the Tablighi congregation, ethical relationships that in turn act upon a person and shape him as a pious person. In the encounter between Amin bhai and I, he was not only trying to communicate "content" of Islamic knowledge to me. Rather, by instructing me, or what Shahzaib called "doing concern" (fikr), Amin bhai was enacting the very ethic of relatedness that is the central feature of the Tablighi congregation. 
To foreground my argument in the rest of this chapter, the form of relations that Tablighis see as central to dawat are hierarchical relations between listeners, like me, and speakers, like Amin bhai. It was this aspect of the congregation that my own ethnographic research fundamentally violated. My desire to amass as much knowledge as possible about Tablighis led me to move, sometimes rather erratically, between mosque individuals and mosque networks in order to gain as much perspective as I could in as little time as possible. Although I tried not to impose my questions on people during practice, it was clear that I would pretty much talk to anybody who was willing to sit and discuss things with me. My research was structured by a certain egalitarian ethic that treated each Tablighi as an equal representative of the movement, regardless of where that person was situated in relation to others. I found myself deeply interested in why new Tablighis were joining the movement, and asking them to explain themselves seemed to violate some basic premise about who can and should speak on behalf of the movement. It is not surprising, then, that many avoided me altogether, as I seemed to disrupt their sense of hierarchical order. I had little or no luck getting Tablighis to give me interviews, as few believed they were qualified to speak on record. They would always direct me to the Elders when I would ask to speak to them on record.

My ethnographic approach disrupted lines of authority. I appeared to Amin bhai and others to be erratic in my search for knowledge and not willing to subject myself to the hierarchical relations that helped craft a person into a proper Tablighi. This is why Amin bhai evoked the figure of "the professor" who frantically searched for knowledge but could not find any "peace." I, too, seemed frantic in my quest, and from his perspective, what I really needed was to anchor myself in the hierarchical relations of the 
mosque. This was essential to the process of becoming a proper Tablighi and a pious Muslim. It is not surprising, then, that it was Amin bhai, a figure of authority inside the Al-Aqsa mosque, who decided to instruct me on how Islam is not a "bookish religion" but a "religion of practice." He did so in his capacity as a speaker. Let us now turn to how a Tablighi ascends this spiritual hierarchy.

\section{SPIRITUAL HIERARCHY AS THE ETHICAL STRUCTURE OF A MOVEMENT}

“The Prophet's every word and every movement became the Companions' faith," Amin bhai explained in the sermon. "When a word left the Prophet's mouth, it would enter straight into a Companion's heart . . . because their love (mohabbat) for the Prophet was so intense." Tablighi sermons invariably stressed this relationship between the Prophet and the Companions couched in the idiom of love. It was their love for him that made his every word settle in their hearts and turn into faith. They felt no need to even consider or evaluate for themselves what he was saying and doing, because they had "certainty" (yaqeen) that whatever he was doing came directly from Allah. It is because of this affective relationship to the Prophet that they would do anything he called upon them to do. "Remember, the Sahaba were only special because of their faith," he continued. "Allah is connected to practice, not the Companions. Be like them and fill your heart with the love of the Prophet."

The Companions are central figures of Tablighi discourse. One of the key texts of the Tablighi Jamaat is the Lives of the Companions (Hayat-us-Sahaba), a compendium about the hardships the Companions endured and how they addressed the issues of their times. The Companions assumed these hardships because of their unwavering and robust 
faith, which itself was predicated on their love for the Prophet. Love (mohabbat) here is not just a feeling but an act of willful submission. For Tablighis, the Companions are model Muslims and the pinnacle for human achievement because they submitted most fully to the Prophet. The Prophet himself was incapable of wrongdoing or, as they say, "innocent," so it was humanly impossible to be like the Prophet, though this is what one should strive to be. The Companions, however, were not innocent. Like all human beings, they made mistakes, and like all Muslims they had to work towards embodying the faith. There was nothing inherent about them that made them so fully pious. This is what Amin bhai meant when he said that "Allah is tied to practice, not the Companions." Yet, as Amin bhai's quote suggests, the words and actions become the Companions' faith by virtue of a specific affective relationship that they have with the Prophet. It is the purpose of every Muslim to cultivate that relationship with the Prophet and through him to Allah, just like the Companions.

This is a recurring theme in Tablighi discourse. Narratives about the Companions serve to instruct the audience about how to create the proper mode of receptivity, and specifically how to cultivate what Charles Hirshkind (2006) as called an ethics of listening. Hirshkind shows how in the Islamic tradition, listening, far from being a condition of passive reception is an active process of embodiment. By invoking the relationship between the Prophet and the Companions, Amin bhai is implicitly drawing parallel between himself as the speaker and the Prophet, on the one hand, and between the audience and the Companions, on the other. He is instructing the listeners about how they should be listening to the sermon with total submission just as the Companions listened to the Prophet. Explicit directives to the audience like "listen with your eyes!" or 
"make your body an ear!" punctuate these sermons, and the Companions stand in for the model of the pious listener.

When Amin bhai was instructing me, his point was that I was not acting like a pious listener. I was not submitting to the word like the Companions and so, even if I was gaining knowledge, this knowledge was not "descending into the heart." Amin bhai was saying to me that this could only happen if I abandoned my research and committed myself to the mosque. It is by participating in the daily mosque activities in my own neighborhood and creating ethical relationships forged through this practice that I would learn how to receive Islam into the heart. In other words, in order to become a pious listener, I had to become part of a community of pious Muslims. Tablighis imagine that such ethical relationships can only emerge through dawat. Through the shared labor of dawat, people come to be joined together in ethical relationships, and through force exerted and desire inspire by these ethical relationships they return to dawat (cf. Mahmood 2001). As I show below, these ethical relationships are conceived as the interlocking of pious speakers and pious listeners through the movement of Islamic signs, both linguistic and bodily, between Tablighis.

The relationships forged in dawat are modeled on kin relations between brothers, on the one hand, and between brothers and fathers on the other. Tablighis add the title "brother" (bhai) before each other's names as marks of respect and they confer paternal authority on to the leaders of the movement whom they refer to endearingly as the Elders. These kin terms connote hierarchy associated with South Asian, especially North Indian, models of kinship in which younger siblings pay deference and respect to older siblings by referring to them by the various honorific titles like "brother" that follow their names. 
Tablighis apply the title "brother" before names to mark off a different kind of relationship, but the hierarchical connotations of the term persist. As one Tablighi explained, "we are all brothers by virtue of our shared relationship with the Prophet, but remember, brothers are never equal." Similarly, the relationship between the congregation and the Elders is modeled on the ideas of hierarchical relations between sons and fathers. Indeed, Tablighis are as concerned with training oneself to recognize these significant social distinctions as they are with learning the ritual repertoires of dawat, and this is because Tablighis assume that one's mastery of dawat as a performance depends on listening to pious others. Hence, ritual and relatedness are entangled processes.

The fact that the Tablighi congregation is primarily a male space, and these bonds are conceptualized as relations between brothers and between brothers and fathers is a central aspect of life inside the congregation. It is beyond the scope of this chapter to fully address the basis for Islamic gender norms, but a few words about how they manifest in the Tablighi Jamaat are in order. Tablighis uphold and adhere to broader Islamic norms of gender separation (pardah) in which, according to Islamic law (shariat), only men and women who are unmarriageable (mahram) can and should interact directly. Women incite male passions and sexual impulses located in the lower self, and should be avoided except in legally sanctioned relationships. Women are understood as a "temptation" (fitna), a word that also means a state of moral chaos, of which women are widely understood to be a source. Women, therefore, must be "hidden" from public view. Indeed, in the Tablighi Jamaat, men must make all efforts to avoid or at least limit any contact with women, first as a separation by departing on all-male dawat tours, and while 
on tours by lowering their gaze and averting their eyes when women cross their path. On many occassions Tablighis would turn to face the wall when women crossed their paths. While on dawat tours, Tablighis avoid telephone conversations with their own female kin because they are understood to be an obstacle to the realization of pious virtue.

If "the world" is a source of temptation for Tablighis, then women are its embodiment. This was most forcefully brought to my attention in a narrative told to me a numerous times by different people. On Judgment Day, all of humanity is lined up awaiting their judgment, the good standing to the right and the bad to the left. Allah presents the horrifying figure of a decrepit old woman, balding and toothless, her skin putrefied and smelling like a carcass, and He says, "here is 'the world' you were chasing after!" This image brings together both the idea that the world is of fleeting importance and that i's temptations are a hindrance to realizing one's true purpose in lif, which is devotion to Allah. But it is clear here that this discourse is also gendered as women stand in as the embodiment of "the world." Tablighi discourse is ultimately directed at men who are seen as the keepers of "religion." The gendered duality of world/religion is homologous to the lower self/spirit duality. Although many of the qualities associated with the lower self including sexual passion and aggression are imagined as "male" qualities, men are also seen as more capable of overcoming their lower self in order to become spiritual (roohani). The male effort to transcend the lower self and escape the temptations of the world is simultaneously an effort to overcome the temptations of women.

It is precisely because of the disruptive potential of women, the threat they pose to social order, which Tablighis, like many other Islamic movements, have focused on 
incorporating them into the movement. But, women's participation in the Tablighi Jamaat remains circumscribed. Women mostly preach in their own local networks, organized through personal relationships. While men meet in mosques, women meet in homes, usually of a committed female Tablighi who has enough space to accommodate the others. Women do travel on dawat tours called mastooraat, which not only means "women" but also means "the hidden." At the root of the word is stoor, which refers to the parts of the body that must be covered. A legally sanctioned male, usually a husband or a brother, accompanies each woman. These trips are less frequent than male tours. Itinerant women stay in the home of a host from the local congregation (maqaami jamaat), while men live and preach in the mosque. Women are barred from giving sermons. Instead, each evening a designated male gives a sermon to women who listen from behind a curtain. Tablighis say that women's voices are tempting to men and so not only must men and women be divided physically but women's voices should also be covered, a phenomenon that they referred to as the "curtain of the voice" (awaaz ka pardah).

Such differences reveal that women are understood primarily as "listeners," while men are understood as "speakers," or, put differently, men embody the generative principle while women embody the receptive one. Even though women participate in the Tablighi Jamaat, neither their bodies nor their words are meant to circulate far beyond their homes and neighborhoods, while men's bodies and words should travel across the country and even around the world. One finds here a set of homologies: male/female; religion/world; and spirit/self. These distinctions are understood in both temporal and spatial terms in that male/religion/spirit are enduring and spatially expansive, while 
female/world/self are fleeting, as suggested by the story of the decrepit old woman, and spatially circumscribed. Hence, the Tablighi Jamaat presupposes and constitutes a gender hierarchy in which male encompasses female.

While the distinction between male and female is understood to be naturally or divinely given, the male/female dyad is also mobilized to elaborate hierarchical relations between men inside the congregation. Among men, relations are presumed to be egalitarian in nature but hierarchical differentiation is created through practice. The notion that differentiation is "made" fits well with long-standing assumptions about Islam as a fundamentally egalitarian tradition. Prominent scholar of medieval Islam, George Makdisi, for example, writes that Islam, more so than any other religious tradition, is "characterized by the basic equality of all Muslims in the eyes of the law, as God's submissive servants" (Makdisi 1983: 85 cited in Lindholm 1998: 209). This perspective has been contested by anthropologists studying Islam in South Asia, especially those focused on Sufi orders organized around the intercessionary powers of Sufi saints (e.g, Basu 1998, Werbner and Basu 1998; Werbner 2005). In South Asia, as in other parts of the world, genealogical descent from the Prophet has played a crucial role in the delineation of hierarchical relations (Ho 2006; Sanyal 1996). The Tablighi Jamaat, on the other hand, comes out of $19^{\text {th }}$ century process of Islamic "reform" that rejected the notion that descent from Prophet conferred special status. Today, Tablighis insist that Muslims, by which they mean men, are differentiated only by their deeds, affirming a form of male ontological egalitarianism.

However, despite this male ontological egalitarianism, the conception of persons as divided between lower self and spirit and the understanding of transformative power of 
dawat inscribes the social world with differences of spiritual rank (darja). Through practice, one strengthens one's relationship to Allah and becomes increasingly "spiritual", understood in terms of "closeness" to Allah. The longer one sacrifices in dawat, the closer one becomes, and this closeness induces what Tablighis call "spiritual power" (roohani quwwat). This closeness to Allah makes one's words "heavy" and "powerful," so that when others hear these words, they are moved by them and are drawn towards Islam. Hence, dawat inscribes words with the power to create spiritual transformations in others.

The Tablighi Jamaat is organized around a hierarchical distinction between "old companions" (puranei saathi) who are those that have conducted the four-month dawat tour and "new companions" (nai saathi) who have not. In the Tablighi Jamaat, the fourmonth tour is given great significance as a spiritual threshold. It is understood as three consecutive forty-day tours (chilla), a time frame that in Sufi cosmology is a period of seclusion for fasting and prayer (Ewing 1997). In the Tablighi Jamaat, the annual chilla is understood as the condition for spiritual renewal. Tablighis compared the chilla to each phase of a child's development in the mother's womb, and three chillas or four-months as the point at which God blows the spirit into the child. The congregation is, therefore, construed in feminine terms as a womb, something within which one grows. Here, one finds the notion of dawat as a form of "rebirth" to be most fully expressed. Dawat tours are, as one Tablighi said using the English term, like "incubators" for making pious persons. The notion that dawat is the "mother of practices" because it gives "birth" to faith, then, is not metaphorical. 
This four-month threshold is both spiritual and organizational, as it divides the movement between old companions and new companions. Although decision-making inside dawat tours and in each local mosque generally happen on the basis of what Tablighis call consultation (mashwarra) in which each person voices their opinion, many key decisions about how to travel and how to organize are made by old companions. Ultimate decision making both during dawat tours and at the local mosque falls to the leader (amir) who must be an old companion. But, more significant than decision-making is the pervasive sense that the four-month tour is the condition for drawing divine vitality (barakat) into one's words, thus making them powerful and capable of drawing others to Islam. Old companions, therefore, train new companions in the Prophet's ways, and especially in how to communicate the message with non-Tablighis, how to keep them focused and engaged. This institutional role is formalized in the genre of the the discussion (muzakira) in which old companions instruct new companions on how to fulfill their ritual obligations and how to perform during dawat.

Old companion is an official designation in the congregation. Each year, and sometimes multiple times in a year, the Elders summon the old companions to the meeting (puranon ka jor) where the Elders instruct them on how to refine their own practices of dawat and increase the efforts of dawat in their own respective areas. These meetings are closed to those that have not conducted the four-month tour. When I asked to accompany my old campanion friends to their meeting, they insisted that new companions are not ready for this knowledge and that it would overwhelm me, and drive me away from Islam. When I asked why, they simply said that knowledge can be dangerous when acquired before one is ready. One Tablghis described knowledge as 
potentially "hot" and others said that it will be like an "intense fire inside you" and then it will burn out and you will then move further away Islam. He explained that when one acquires knowledge but is not prepared for it, he misuses it, and therefore can do great damage both to himself and to others.

I had the opportunity to speak to Talha at length about these comments, and he explained to me that knowledge acquired with the proper preparation and instruction, and outside of the process the Prophet's tradition (sunnat), rather than disciplining the lower self, will actually incite the passions of the lower self. It will create extreme desire for the power that comes with religion, and rather than "awaken the spirit" (rooh ko jaga deita hai), it produces hubris (takabbur), conceit (khud garzi), stubbornness (zidi pan) and selfishness (matlab parasti). Such knowledge he said is "false" and will produce the opposite of virtuous dispositions associated with "faith." Indeed, what was true of knowledge was even true of practice (amal), as Tablighis discouraged people from going on the four-month tour until they had first done a few forty-day tours, and they encouraged people to do several three-day tours before embarking on the forty-day tour. This was not always adhered to but the idea that a gradual accretion of both faith and knowledge is better was generally agreed upon. Indeed, this returns us to Amin bhai's story about the professor who had a great deal of knowledge but had no peace because he did not know what to do with that knowledge.

The relationship between new companions and old companions is relationship of pedagogical discipleship in which the former are trained by the latter. This relationship is seen as necessary for the proper cultivation of virtues. Knowledge acquired independent of this process is understood to be detrimental to the cultivation of virtues. Hence, 
although virtues are considered a condition for ethical relationships, ethical relations are themselves seen as being the condition for virtuous becoming. The relationship between new companions and old companions is imagined in terms of the duality of the lower self and the spirit. New companions are seen as being closer to their lower self, while old companions are understood as being closer their spirit. The subordination of the former to the latter is part of the proper order of Islam. Indeed, knowledge acquired independent of this process, and this has implications for the whole range of what Tablighis call "everyday ties," is seen as undermining the very process of becoming virtuous. This was the story Amin bhai was telling behind his claim that Islam is a "religion of practice" and not a "bookish religion." Because of my approach to knowledge, one that failed to submit to the authorities, including him, to whom I should have been submitting. Thus, I was failing to embody the virtues of Islam.

If the relationship between old companions and new companions is framed by the duality of the lower self and spirit, it is simultaneously a duality between speakers or givers of Islamic knowledge and listeners or receivers of Islamic knowledge. While all Tablighis are in the process of becoming speakers, it is the old companions who assume the authoritative discursive position in mass gatherings such as at shab-e-jummah or at city and national congregations. It is also the old companions who designate tasks to the new companions, including who will give the weekly sermon and who will go on the preaching tour. And, the distinction between the old companions and the new companions is only the most significant threshold. Besides the four-month threshold, there are also distinctions within the old companions between those who have done 
seven-month tour that usually takes one outside the country, and the one-year tour, which similarly takes one beyond the country.

This duality between lower self and spirit, speakers and listeners, is even developed in the relationship between the congregation as a whole and the Elders of the movement. For Tablighis, the pinnacle of religious achievement are the Elders who sit on the city, district, national and international councils. At shab-e-jummah, it is the Elders who give sermons to which the entire congregation listens, though occasionally they will confer the opportunity to someone who has done the seven-month or one-year tour. The Elders speak from the pulpit at the various city and regional congregations that attract thousands if not hundreds of thousands of people as well as the annual congregation in Raiwind, Punjab that attracts hundreds of thousands if not millions of Muslims. Here, the idea of heavy and powerful speech is most fully elaborated as Tablighis spend three days praying as well as listening to sermons (bayans) given by the Elders. The annual congregation transforms all Tablighs into a collective body of pious listeners. As one Tablighi explained to me, "the Elders are a channel for words that come directly from Allah.” This was a dramatic and I would say rather dangerous claim because it comes perilously close to equating the Elders with the Prophet, who was the only one capable of channeling divine words, and not everyone would have agreed with this statement, but the notion that the Elders had a more "direct" relationship with Allah, through their embodiment of virtue, was well accepted. Many said that the Elders had received "divine guidance" (hidayat) directly from Allah, which brings with it the presence of Allah in one's life, a presence that although not entirely secure is certainly more permanent. Having received divine guidance means that one's speech is particularly powerful and 
one's supplications are readily accepted by Allah. Conducting the four-month tour was not sufficient for receiving guidance, which is reserved for an elect few, but it is seen as a necessary condition. This "direct" relationship came with "spiritual powers," including, some said, the power to be able to see what is in others' hearts. The ability to see the hidden/interior (batin) especially as opposed the apparent/outer to which all others are confined is a characteristic traditionally associated with Sufi spiritual guides or "sheikhs" (see Gilsenan 1982). In the Tablighi Jamaat, this capacity is something one cultivates through dawat, but it is not guaranteed but is a divine gift that one receives due to one's sacrifice for Allah.

The structural relationship between new companions and old companions and between the congregation and the Elders is constructed in ways similar to the relationship between the Prophet and the Companions. It is a hierarchy rooted in the notion of precedence. Much as the Companions related to the Prophet in terms of total love, the congregation of Tablighis should relate to the Elders by cultivating the receptivity that allows one to draw their words directly into the heart. But, these distinctions, much as the distinctions between old and new companions are only the most formal distinctions. What one finds in the Tablighi Jamaat is that people credit specific people with having brought them into the movement, often fondly remarking on who was involved in their transformation and how their life was before they became involved in dawat. Tablighis say that whoever brought you to dawat receives the merit (sawab) of your future work and you will receive the merit for the work of those who you draw to dawat. Tablighis describe dawat as "growing one's heaven," by which they mean that as one gives dawat, one is simultaneously acquiring the merit that will literally grow the space of one's 
heaven. At the same time, one is creating one's own chain of transmission, a chain that arguably leads back through the Companions to the Prophet. The goal of dawat, then, is to create one's own chain of transmission, which will continue to draw merit in the future, well beyond this life. As Talha once jokingly remarked, dawat is the only "pyramid scheme" (in English) that works as everyone benefits from it. Others described it in more local idiom as a tree with leaves that will never go dry and will always bear fruit.

What I have described here fits with the broader understanding of piety as a form of self-mastery achieved through ritual practice (Asad 1993), which, as I showed in chapter 3, is understood by Tablighis as the subordination of the lower self to the spirit. Through dawat Tablighis are able to refashion their lower self in order to become "spiritual" (roohani). Being "spiritual" here is understood in terms of the acquisition of affective qualities of piety like pious fear, humility, patience and love. For Tablighis, these ethical dispositions must be cultivated through relationships with pious others who are further along in their spiritual development. It is only through these ethical relationships that one comes to inhabit pious virtues oneself. My point is similar, then, to the one made by Brian Silverstein $(2008,2011)$ in his study of Naqshbandi Sufis in Turkey. Silverstein shows that ethical cultivation through an "ethic of companionship," in which one comes cultivates Islamic virtues by living in the presence of "good" Muslims. Silverstein shows that for Naqshbandi Sufis, it is crucial to cultivate a relationship with the sheikh or spiritual leader whose spiritual power suffuses the congregation and makes Allah's presence felt in the life of the devotee. I will have more to say about this in subsequent chapters. For now, it is worth noting 
that the relationship between the sheikh and devotee is modelled on the relationship between Prophet and his Companions and is understood to be a relationship based on love. The Tablighi Jamaat draws on a very similar ethic of companionship, but for Tablighis it is dawat itself that generates these ethical relationships, which in turn act upon a person. Hence, if one relational axis that dawat creates is with Allah, the other is, as Tablighis frequently point out, the relationship or "ties" (jor) between Muslims.

I could not help but find parallels between Tablighi claims dawat as a sacred practice generated "ties" and Durkheim's classic thesis that rituals function to reproduce social relationships. For Durkheim, morality was itself a system of rules that determined social relationships, and therefore, in reproducing the social, rituals were also recreating a moral world (see Laidlaw 2002; Lambek 2010). Indeed, Tablighi understandings read like amended version of Durkheim's thesis in that dawat creates ethical relationships built on the "truth" (haq) and "the good" (achai) as opposed to relationships built on "falsehood" (batil) and the bad (burai), suggesting that what was at stake was not that persons were brought together in relationships but the ethical quality of these relationships. In other words, dawat did not function simply to reproduce social relationships so much as move between what relationships are or would be absent of Islamic practice to what they ought to be, a movement from the ostensible to the subjunctive (see Lambek 2010;6-7). When asked what these ethical relationships entailed, Tablighis described them in terms of love (mohabbat), respect (izzat), care and concern (fikr), affections that "Allah puts in one's heart." These affective ties were both 
the product of Islamic practice as well as the condition for practice insofar as they kept one committed to dawat (cf. Mahmood 2001).

Piety, then, as conceived in the Tablighi Jamaat might be understood as virtuous dispositions internal to an individual, these virtuous dispositions are themselves the product of ethical relationship within which and through which ethical selves are cultivated. The Tablighi Jamaat, then, understands its project to be one of creating a social order based on Islamic principles but becoming an ethical person, one capable of living in Islamic terms, requires that one learn how to live in a hierarchically structured social world. It is by participating in this sacred hierarchy that one comes to have a relationship with the Prophet and through the Prophet with Allah.

\section{ISLAMIC SIGNS, AGENCY AND SPIRITUAL HIERARCHY}

The sacred hierarchy through which one comes to inhabit virtuous dispositions is not understood as a fixed structure, but a process of ritual creation, and it is this process that Tablighis regard as distinctly Islamic. In the Tablighi Jamaat, the concept of dawat implies the circulation or movement of sacred signs in the form of words and bodily actions between persons. These signs carry special powers or divine agency and can therefore transform others and draw others to Islam. A close interlocutor of mine, Abid, explained to me that God imbues Islamic signs with special powers when they are born out of sacrifice:

I have heard from the 'ulema ikraam that Allah does not even allow the words of dawat that are truthful to fall to the ground. Allah always makes these words the channel for someone's guidance. 
In this quotation, although the one directs dawat towards a specific person, it is clear that sacred words once released will circulate until they find receptive person whose heart they will settle in and will draw to Islamic practice. In this statement, Allah's agency inheres in these words and guides them to their ultimate destination. Tablighis frequently say that a person's duty ends once he has delivered the words and that one does not really know how many people one has actually affected. How many people one has affected actually only comes to light in the afterlife. It means that one need not even be aware if the dawat one gives has been efficacious or not, leaving open the possibility that someone far removed from the actual speech act could have been transformed. This is also why Tablighis regard bodily signs as essential, because then one becomes a walking image of the Prophet, which has the potential to bring other people towards Islam without one even knowing it.

This perspective on the creation of an Islamic order through the circulation of Islamic signs has parallels to what Nancy Munn (1986) described in her seminal work on the Melanesian kula ring, The Fame of Gawa. According to Munn, practices like the Melanesian kula ring that circulate valuable objects are "practices by means of which actors construct their social world, and simultaneously their own selves and modes of being in the world" (1986: 7). In these practices of exchange, Munn notes, the acting subject is also the "acted upon" self (1986: 14; cf. Mittermeir 2012). In other words, people create their own selves in the very process of creating definite types of social relationships. Kula shells, Munn argues, are the embodiments of a person's self and they carry the name of their possessors. Melanesians place great stress on the autonomy of persons, and a person exercises autonomy by deciding to whom kula shells are released 
and the appropriate time of release. However, when a man releases a shell to another, he also indicates that he has been influenced by another and therefore simultaneously subordinates himself to that person. Hence, Kula exchange is central to the production of legitimate hierarchy through persuasion and consent in an otherwise egalitarian social system.

In Munn's analysis, the possession of certain named Kula shells circulates the name of the person who possesses the shell as an objectification of their influence over others. In every transaction of valued Kula shells there is a "virtual third party" that witnesses the transaction, a party to which the name of the possessor travels, creating what Munn calls “fame.” Munn writes, “Fame extends a man's immediate influence on the minds and actions of partners to distant others - that is, the influential acts of any actor — as being the potential for influence on the acts of a third party other" $\mathrm{K}(1986$ : 117). By engaging in Kula transactions, a man creates a name for himself and therefore creates influence over the minds of others. Kula shells are the objectified form of a person's self and are associated with his name. Fame represents the influence of a person on the minds of distant others, and therefore, Munn notes, represents the spatiotemporal extension of a person's self.

This is a useful way of understanding how Tablighis think about dawat as a sacrificial practice through which a person's self is fashioned at the same time, and in direct relation to, the production of a larger, morally conceived social order. In the case of dawat, unlike Kula exchange, the objects being circulated are not objects as such but objectifications of words and actions, words and actions understood to carry the mark of the sacrifice of the person. Much like in kula exchange, Tablighis understand dawat to be 
the proper means of generating spiritual rank (darja), understood as proximity to Allah through persuasion and consent. Dawat creates hierarchy in a social system that is otherwise egalitarian. As in the Melanesian case, in the Tablighi Jamaat, the interiority of others is understood as opaque and hidden from general view. As Tablighis often say, "we have purview over the apparent (zahir), not the hidden (batin)." This means that while one can force someone to act in certain ways, they cannot force another to come to Islam, and that each individual is autonomous and must come to Islam through their own volition and agency, or actually, they must be acted upon by Allah's volition and agency. Dawat is the legitimate means through which Muslims solicit Allah's power in order to draw others to Islam. Through this act of sacrifice, the giver of dawat appropriates value to himself, value that is understood by Tablighis to come not only in the form of "merit" (sawaab) but also in the form of the virtues of character (sifaat) that I have described.

The parallels between kula and dawat do not end there. In fact, although Tablighis say that one should not be conducting dawat simply to increase one's own name and reputation (naam), the circulation of the names of specific people is an integral part of how dawat actually works. One finds, for instance, entail a complex citational hierarchy in which old companions are invoked along with the Elders, the founders of the Tablighi Jamaat, renowned Islamic scholars and saints, paramount figures of Islam like the Companions and finally the Prophet. These citational practices situate a speaker as a channel for the words of pious others. The goal for every committed Tablighi, it seemed, was to become part of the citational universe of Tablighi sermons, example (misaal) to be referenced. Similarly, the names of committed old companions and certain mosques, like the Al-Aqsa mosque, become well known through the informal circulation of names. 
Moreover, the names of Tablighis and virtuous mosques are tallied in an elaborate Tablighi bureaucracy, and often referenced by the Elders in their sermons. Individuals that have conducted the seven-month or one-year preaching tours are invited to the quarters of the Elders to be recognized and given a chance to speak at shab-e-jummah, where they command an audience of thousands of Tablighis. The official bureaucracy then regulates fame in the Tablighi Jamaat, and although Tablighis insist that Allah is the only "real witness" that matters, one might still say that that designation of witness should also go to many pious others, especially the Elders.

What Tablighis are constructing through dawat is what Munn has called an intersubjective spacetime, which she describes as a "spacetime of self-other relations constituted in terms of and by means of specific types of practice" (1986: 10). Indeed, for Tablighis, dawat is about the creation of particular self-other relationships, and much as in Munn's description, it is the spatio-temporal extension of the self that defines one's value relative to others in a spatiotemporal order. This becomes clear when we think about how one ascends the ranks in the movement. As I explained in Chapter 2, one does one weekly tour in the neighborhood and one in an adjacent neighborhood, a three-day tour (sehroza) each month that takes one outside the city, a forty-day tour (chilla) each year that will take one to specific parts of the country, a four-month tour at least once that will take one across the country, then a seven-month and one-year tours that will take one out of Pakistan to various parts of the world. As one moves outwards from a center, one extends the circulation of one's sacred words and actions, and simultaneously rises in the ranks of the hierarchy. The movement is from one being a local actor to one being a global actor. This process was explained in one of the middle talks I recorded: 
People think that there is no solution to the world's problems. All these things you see around from floods, to target killings, to crime, to corruption, all of this hurts the religious as much as it hurts others. . . But people think, 'I am just one person. How can I solve the world's problems?' . . . But, if you give time to the mosque, all the world's problems can be solved. There are twenty-four hours in a day. Eight of these hours are spent working, eight hours resting, and eight with family and friends. But if you give even 3 hours to the mosque, you will see that your life will change. You will take what you learn from the mosque to your work. You will know not to be dishonest in your dealings with others. You will bring religion to your family. You will have daily reading (taeleem) in the home, and you will be able to teach your family religion, and you will be able to help your friends as well, who in turn will help their family and friends and so on. . . You see if you give time to the mosque, then you can help change your family. And if you do a weekly gasht, then eventually you can bring at least your neighborhood to religion, right? And if every month you do a three-day tour (sehroza), you can change your city, and if every year you do a forty-day tour (chilla), then you can change your province, and if you do 4 months, then you can reach the whole kcountry, and if you do 7 months then you can reach the whole world. So if a person puts in time in the jamaat, he can bring religion to the whole world!

In this statement, each stage of dawat corresponds to a spatial area that is transformed through dawat, and as one moves further along the stages, the spatial area grows. One begins with the mosque in one's own neighborhood, which has a transformative effect on the most intimate of relationships with kin, friends and neighbors, and from there one moves to the level of city, province, country and finally to the entire world. The image one is left with here is a series of concentric circles that move outwards from sacred core of one's own neighborhood that encompasses the more intimate relations of kin, friends and neighbors, to relations and geographic space further and further removed. In other words, one goes from being a "local" actor to being a "global" one.

As one progresses through the stages of dawat, from the most concentrated to the most dispersed, one's sacred words have a wider and wider audience, thus greater and greater possibility for the creation of an Islamic spacetime. In the process ascending the 
Tablighi hierarchy, one comes to acquire greater and greater recognition or "fame" in the movement as well, which is indexed by the size of the audience one acquires inside the congregation. Generally speaking, new companions only give sermons in their own local mosques and are encouraged to develop their sermon-giving skills on dawat tours. In other words, they are speakers only to those outside the movement. They do not give sermons to fellow Tablighis at places like the city or national congregation, and are therefore considered "listeners" relative to other Tablighis. Old companions speak for their mosques at both shab-e-jummah and at the annual congregations. In shab-ejummah, Tablighis are seated with in their respective city districts. Tablighis, at least experienced ones, are aware about the status of others not only in their own mosques but also their own districts, and so they are familiar with the status of people around them. Similarly, in the annual congregations, one is seated with those of mosques about which one has the most intimate knowledge. Prominent Tablighis, like Amin bhai from prominent mosques like Al-Aqsa assume responsibility for giving sermons to less prominent Tablighis from less prominent mosques. The Elders of the movement, whose sermons circulate through material media like cassettes and CDs are both speakers relative to the entire Tablighi congregation of pious listeners and are clearly the most universal of voices.

One can then see clearly how a Tablighi's movement outwards in terms of space is simultaneously a movement upwards in terms of a spiritual rank inside the congregation. As one moves further and further away from the center, one grows in stature inside the movement. In other words, in the process of creating a spiritual world, one also produces oneself as a spiritual subject. Similar to Munn's notion of the creation 
of a timespace through the positive transformation of value. Through dawat, Tablighis are creating an Islamic spacetime understood in terms distinct self-other relations, at the same time that they are appropriating value to themselves in terms of virtue. This value takes material form in the circulation of names throughout the Tablighi congregation and in citation practices wherein specific people are referenced for their religious work, especially in sermons. Spiritual rank is also indexed by the size of one's audience in the congregation.

\section{CONCLUSION: SPEAKING AND LISTENING IN THE ETHICS OF RELATEDNESS}

Let us now return to the question with which we began this chapter. Why did Amin bhai think I was not cultivating faith despite spending all this time around Tablighis? What is the difference Amin bhai was pointing to when he differentiated Islam as "religion of practice" from a "bookish religion"? I have argued in this chapter that dawat entails a commitment to a sacred hierarchy, a hierarchy that is itself emerges through the practice of dawat. Tablighis believe the material and bodily sacrifice of dawat produces powerful Islamic signs that circulate in order to create an Islamic social order, the creation of which also acts upon the Tablighi propelling him towards Islamic ideals. In many ways, this replicates in a native idiom precisely the point I made about performance in Chapter 2, which is that it is through the enactment of Islamic signs that one comes to act in accordance with their ethical entailments. Similarly, here I argue that through dawat on ascends an Islamic hierarchy. It is worth noting here that the higher moves up this Islamic hierarchy, the larger is one's audience and hence, the greater is the scrutiny under whcih one now finds oneself. I was consistently told the Elders shouldered 
a great burden because their every movement was scrutinized. They had to act in accordance with the highest Islamic ideals or they could lead countless people astray. This requires unwaverying and certain faith like that of the Companion, so that they can live an exemplary life.

As I suggested earlier, my ethnographic practice carried its own ethical presuppositions. It treated each Tablighi as being equally "representative" of the movement and equally capable of speaking about dawat. I wanted to understand their own perspective on Islam, but from the perspective of my interlocutors, this was not how one approached Islamic knowledge. My ethnographic practice entailed modernist and egalitarian assumptions that assumed that each Tablighi could speak for himself and for others in the movement, but Tablighis consistently directed me to pious authorities, and instisted that it was not their place to represent Islam. My approach asked them to be speakers when they insisted that they themselves were merely listeners. By asking them to speak, I seemed to be jeapordizing their faith. It is for this reason that so many Tablighi evaded conversations with me, especially those who were new companions.

Moreover, because of my own background as a Sunni Muslim raised in Pakistan, and partly as a result of my ethnographic experience, I came to understand that my own place in this movement was basically not as a "speaker" but as a "listener," and that every time I consciously pursued my ethnographic data, I was violating the unspoken rules of an Islamic order. Not only was I turning everyone into "speakers," I was also, prematurely, becoming a speaker myself. I spent much of my time simply sitting and listening, but this did not always yield what I had originally thought to be "data," which led to frustration and anxieties about my research. I would, then, try desperately to 
acquire what I thought I needed, speaking to whomever I could speak to. Most new companions referred me to the old companions and many old companions referred me to the Elders. Almost nobody was willing to be interviewed, and all expressed concern that their thoughts would become objectified in print and would circulate far and wide. In fact, the very idea that I would be writing a book about Islam drew responses of shock and horror from Tablighis. How, they thought, could I possibly be speaking authoritatively about Islam? It was clear that they thought my book would become a vehicle for leading others astrat. Many Tablighis encouraged me to abandon my research and to focus on the work of dawat, which would itself bring the understanding I was so desperately seeking. On a number of occasions, Talighis told me that if I conducted the four-month tour, which would obviate the need for more research. I would understand enough that I could speak authoritatively about it.

My ethnographic practice, then, carried its own ethical presuppositions, which seemed to turn me into the restless professor of Amin bhai's story, running around, trying to find knowledge but never finding comfort and peace. A number of my close Tablighi friends jokingly told me that the letters P.H.D stand for phira hua dimagh or "restless mind," a phrase that implies a person who lacks basic moral sensibilities, is prone to erratic behavior and outbursts, and generally is without comfort or peace, just like the Professor of Amin bhai's story. Many of my Tablighi friends, including Shahzaib, explained to me that while acquiring knowledge is important, one must have the requisite faith to make sense of that knowledge. Shahzaib explained to me that while I was acquiring some knowledge this knowledge seemed to be empty of divine vitality (barakat). The term here barakat has no English equivalent but roughly means "purity 
and fullness." For instance, the consumption of very little food that has barakat gives you satisfaction and makes you full, while one can endlessly consume food without barakat and never feel satiated. Similarly, with knowledge, religious knowledge has purity and fullness, which means that it induces spiritual fulfillment in a person. That this purity and fullness derives from Allah means it does not exist in anything that does not have His sanction. What Shahzaib was saying, then, was that my approach to the acquisition of knowledge would prove empty because it lacked divine sanction.

My desperate quest for knowledge itself seemed to index the very lack of faith that dawat is meant to induce. I struck those around me as being obsessed with what is hidden (batin), to which my interlocutors frequently said that the "truth" (haq) is very simple and in plain sight or apparent (zahir). In other words, the truth was not to be found in great depths but on the surface of words and actions (cf. Keane 2010). What I needed was to apprehend it by honing my faculties or cultivating receptivity (Hirshkind 2006). As I have suggested throughout this chapter, honing one's faculties requires that one assume the stance of a pious listerner to those above oneself in spiritual rank, something with which my ethnographic practice was at variance. To make clear what I mean here, let me draw on the example of Shahzaib who, unlike me, was seen as having successfully become a pious listener in the same period of time.

Shahzaib and I had gone on our first preaching tour together, which took us from Karachi to Multan and to the national congregation in Raiwind over the course of fifteen days. While I went from there to Lahore and ultimately back to Karachi, Shahzaib went along to complete his first forty-day tour (chilla). Shahzaib, like me, had intended to return to Karachi but after much cajoling, the others had managed to concinve him to stay 
on for the rest of the tour. I, on the other hand, exhausted and knowing that I would have to go on other tours with other Tablighis decided to return to Karachi after a brief stay in Lahore . I was not surprised that Shahzaib had agreed to stay. He came from a family that was deeply involved in the Tablighi congregation. His father, who was an old companion, had encouraged him to go on the forty-day tour, and Shahzaib had a number of cousins who were very active in the movement. Shahzaib told me he felt he should pursue dawat to uphold the values of his family. More significantly, though, as he expressed so clearly to me, he wanted to please Hazrat, and he said to me repeatedly, he wanted to be "close" to Hazrat like Talha was close to Hazrat.

Shahzaib's desire to please Hazrat clearly preceded any actual participation in dawat. He desperately wanted to forge a closer relationship with Hazrat, something he told me many times. On the first day of our tour, he told me how much he wished Hazrat would look at him the way he looks at Talha. Although Shahzaib had a desire to participate in dawat, he was seen by many of the others I knew as not particularly good Tablighi. Over the course of our first year as Tablighi, several people had told me that Shahzaib lacked "control over his tongue" and "didn't know when to talk and when to listen." Indeed, these were the kinds of comments that one heard often about people, and they attributed this to the problem of hubris (takabbur) and self-centeredness (khudgarzi). Shahzaib's family owned a successful textile factory, which meant he was wealthier than many of the others in the Al-Aqsa congregation, and he had studied textile design in the US as wel and his English was significantly better than those of the others. Some Tablighis I spoke with perceived that background to be a source of his "wordliness" (dunyadari). It was true that this background made Shahzaib gravitate towards me, and 
was, in part, the source of our friendship. It was also true that Shahzaib regarded some of the others to be insular and less worldly (in the positive sense of cosmopolitan) than him.

Overtime, however, I began to witness a shift in Shahzaib's attitudes towards others in the mosque. He assumed increasing responsibility inside the mosque, like committing himself to "service" (khidmat) at shab-e-jumma, and devoting time to help organize mosque activities. Furthermore, the more involved he became in mosque activities, the more he came to speak about the virtues of other Tablighis, often elaborating the positive qualities (sifaat) of others, and, in particular, those of the old companions. On one occasion, Shahzaib pulled me aside and without any prompting began praising Amin bhai. Shahzaib told me that recently Yassen bhai explained to him so much about the importance of the Elders and how what makes them so special is that they do not even want to be treated as the Elders. "Amin bhai is very faithful and knowledgeable. One can learn so much by spending time with him," Shahzaib said. Noe here that what Shahzaib is conveying to me is not only praise of Amin bhai but also praise of Amin bhai's praise for the Elders. On another occasion, Shahzaib catalogued the different qualities of various members of the congregation like their "softness of temperament" (narm mizaaji) or their "lightness of temperament" (khush mizaaji) or their "concern for others" and so on.

This sort of discourse of praise for those more pious than oneself is common in the Tablighi Jamaat. I believe it is precisely the kind of ethical discourse that Tablighis understand to be the quality of a pious listener. This shift in Shahzaib was not lost on other Tablighis, who increasingly started seeing him in a more positive light. When Shahzaib began he had wanted a "direct" relationship to Hazrat, a relationship that he 
was eager to acquire and this led him to dismiss others around him. Gradually, Shahzaib had come to see the value of all the levels of piety that stood between him and Hazrat. Increasingly, the congregation came to resemble the layered relations of the Prophet and his Companions, who all had different statuses and qualities. This might seem like the kind of everyday talk that one finds in any community but for many Tablighis I spoke with, this subtle shift marked Shahzaib's transition from worldliness to piety

What I want to stress here is that this transition in Shahzaib is understood as the capacity to transmit the words of others, others who are above one in spiritual rank, such that the listener is inspired to emulate these virtuous others. This transition from wordliness to piety is also one from hubris to humility and self-centeredness (khud gazri) to collectiveness (ijtimayat). This is the mark of having a disciplined lower self and being spiritual. If dawat is the formalized, ritual process of transmitting Islam, then becoming a pious listener to and transmitter of the words of others is the everyday corollary of that process. Through formalized dawat one rises in spiritual rank, but it is the everyday work of listening to those above oneself and transmitting to those below is the mark of an ethical subject. Tablighis frequently say that one should make commit one's entire life (puri zindagi) to dawat, and what they mean by this is not that one should abandon "the world" and spend one's entire time conducting religious tours. Rather, they mean that one should train oneself to recognize one's place in a spiritual hierarchy and become effective transmitters of the words of pious others. This is what Amin bhai meant when he said, "make your whole body an ear!" Becoming a pious listener requires cultivating the willingness to listen, to be acted upon, and to embody the authority of others, and then to 
be able to convery that to others such that they too will want to relate and connect to the movement and assume their own place as pious listeners.

When Amin bhai was explaining that Islam is a "religion of practice" and not a "bookish religion," he did not mean that texts are unimportant in Islam. Textual reading practices are a central part of the Tablighi ritual repertoire. What he meant is that one could not acquire Islamic knowledge simply by acting on one's own, whether that be by reading a book or directly speaking to people. One had to, as it were, follow the correct process (tariqa), which as I have shown means allowing the voices of others to speak through one's own voice. My ethnographic practice, premised on certain egalitarian and individualistic values, was an obstacle to becoming a pious listener. And, as I was failing to be a pious listener, I would also, inevitably, fail to be a proper transmitter of Islam. The idea that I would be objectifying my understanding of Islam in the form of a book, a book that could potentially circulate widely, horrified many Tablighis. A person who had not learned to transmit Islam would inevitably create "innovation" (bidat) on the original sources, spreading "falsehood" (batil) rather than truth (haq). This is why my research among Tablighis proved difficult. On the other hand, I was also seen as a person who had great reach as I could transmit Islam to people in the US and across the world. In a way, this "worldliness" could be converted into an asset, as long as I were to become a faithful transmitter, which according to many Tablighis like Amin bhai I was refusing to do. A number of people jokingly suggested that when I become a professor, I could turn my entire university to dawat. This is likely why Hazrat informally endorsed my research. I, therefore, occupied an ambivalent place in the eyes of many people, both as a source of danger and as someone with great potential. When Amin bhai sat me down at shab-e- 
jummah to explain that Islam was a religion of practice, he concluded by saying, "Arsalan, you have access to many people that we here do not have access to, so you must bring yourself to the Prophet's way." 


\section{Chapter 5 \\ FROM PRECARIOUS TO CERTAIN FAITH: THE MAKING OF A SPIRITUAL HOME}

Umar and I had met during our trip from Karachi to Multan to the national congregation in Raiwind. He was a close friend of Talha's, and he was a faithful follower of Hazrat who was always available for service (khidmat) at Hazrat's spiritual house. Umar was a jocular young man in his late 20s who sold cars. When I met him, he was working as a middle-man between buyers and sellers of new and used cars, and he was in the process of acquiring space in his friend's car showroom in order to begin selling directly to customers. He was also a very capable cricketer who had briefly played in the club circuit, which is a level below national cricket, and he knew many of Pakistan's national cricketers as friends. To differentiate him from the many other Umars, the name of the Prophet's Companion and second Caliph of Islam, in the Tablighi Jamaat, he was referred to as "Umar cricketer." Besides being a capable cricketer, Umar was also a remarkably adept Tablighi. He drew on a wide repertoire of Islamic textual sources, including a few Persian couplets, in order to establish his rhetorical authority in dawat. He evoked sharp contrasts between "religion" and "the world," painting the image of a corrupted and fallen world that had to be redeemed by infusing it with the spirit of Islam. "When mosques are populated," Umar often retorted, “our prisons and mental asylums are empty. But, when mosques are empty, our prisons and mental asylums are full."

Umar's charisma and his ability to connect with young people was acknowledged by all. I witnessed this charisma as we walked together through a boys' high school in Multan, giving dawat to young students. The students were mesmerized by Umar's rhetorical acumen and his ability to connect Islam to their everyday lives. They were also 
quite riveted by the stories he told about his adventures with cricketers. Umar frequently pointed out how many of the crickets of the national team were affiliated with the Tablighi Jamaat, and he implied the possibility that they, too, might get the opportunity to meet them. That Umar brought up his relationship with national cricketers at every possible occasion was a running joke among his Tablighi friends, but everyone agreed that, even as there was something a little self-serving about these stories, they were an asset when drawing others to the movement. That day we convinced around 7 or 8 students to come back to the mosque for prayers and to listen to the sermon, an achievement by all standards.

My own relationship with Umar was also quite enjoyable. Umar spoke very little English, less I would say than many other middle-class Pakistanis. He would speak to me in a deliberately exaggerated English accent, stressing the foreignness of the tongue and mocking me for being English medium. I enjoyed this joking enough that I also started speaking to him in a deliberately accented English, and we would carry on, sometimes to the amusement of others, in an entirely unintelligible language consisting of exaggerated English sounds. Umar had an inviting sense of humor. He would often reframe Tabligh discourse in the form of jokes. "Pass 'the world' over here," he said, pointing to his phone. He would also try hard to put me on the spot by drawing scrutiny towards me, "Arsalan could do so much for the religion if only he would try," and, on another occasion, “Arsalan, you are too full of 'the world.' It is minced in your bones!” More than once he would turn to other Tablighis and say, "Let him be. He is a gone case." Humor was an important way to develop camaraderie in the Tablighi Jamaat, and Umar was particularly gifted at this. The highlight of that trip was probably Umar and I playing 
cricket in the courtyard of the mosque, and to my amusement others joined in, including the Imam of the mosque. This was indicative of Umar's ability to draw people together in ways that made life inside the congregation much more than just a ritual process.

Yet, for all this light natured fun that Umar brought to the congregation, which many understood to be an asset, Umar would frequently descend into a deep solitude that was so marked by its seriousness that one could not help worry about him. For hours, Umar would commit himself to reading and recitation of the Quran. During these bouts of reading and reciting, he became so intensely involved that he would not speak to anyone for hours. Umar would then walk around solemnly, without any hint of humor or laughter. At one point, in one of these serious bouts, Umar turned to me approached me and apologetically said, "you know, I only make these jokes so time passes quickly and to make things easier on myself and on others. Every night I pray and ask Allah to give me more faith, so I can spend my time in practice, but it is difficult.” On another occasion, Umar explained to me how faith is fickle. "One minute it is here," he said raising his hands above his head, "and the other minute is way down here," reaching for the floor. Indeed, I had come to see that Umar, for all his charisma and all his ability to draw others to Islam, was racked by self-doubt about his own faith.

I found Umar's vacillation between fun and seriousness to be rather dramatic, so I asked others if this was common for people in the Tablighi Jamat. The best person to turn to about this was Talha who had been on a dawat with Umar several times and who knew him well. Talha said that Umar has the tendency to become "dried out" (khushka). Talha explained to me that when one is out on "the path of Allah" one should focus intensely on one's practice because practice carries much greater religious merit on the tour than it 
would otherwise have sitting at home. I responded that this means it is good that Umar focuses so intensely on his practices, and Talha explained that it is good to focus on practice, of course, but going from one "extreme" [in English] to another is not good, and that one needs to have "balance" [in English]. It was odd to hear someone who was himself so intensely focused on dawat suggesting the need for balance, when in fact the typical response of Tablighis is that there can never be too much practice. But, Talha's point was not that Umar was too committed to practice. The goal of dawat was, after all, to make one's "whole life" a practice in the image of the Prophet. Rather, Talha's point was that the movement from one extreme to another indexed a problem in his practice, and that "balance" was itself a product of correct practice. The term "balance" here was clearly being used in a manner similar to how Amin bhai used the term "peace" (sukoon), which derived from doing dawat properly.

What I wondered could possibly be the problem with Umar's dawat? He was, after all, an "old companion" who had done the four-month tour, regularly attended Thursday night congregations, committed time to his own mosque, and was a regular at Hazrat's spiritual house. He was also an extraordinarily adept Tablighi. I saw Umar as a model Tablighi, yet he too seemed to fail to live up to Tablighi ideals of Islamic virtue. Given that Umar was carrying through what Tablighis deemed understood as the ritual process, my initial reaction to the issue was to dismiss it as simply an idiosyncratic problem. However, the more time I spent around other Tablighis, the more I saw how, rather than being idiosyncratic, Umar's deep anxieties, his lack of certainty, and his doubt, was a recurring theme in Tablighi life. It indexed the precarious nature of divine presence in everyday life. And, while divine presence is difficult for all Tablighis to 
secure, I realized that this affliction did not affect everyone equally. In other words, although Umar seemed to be fulfilling the conditions for the efficacy of dawat, there were aspects of his social existence beyond the space of the Tablighi congregation that seemed an obstacle to the process of virtuous becoming.

In the last chapter, I argued that it is a specific ritual process that is a necessary condition for the embodiment of Islamic virtue. Central to this ritual process, I showed was living within a spiritual hiearachy. Becoming virtuous entails becoming a pious listener to those more pious than oneself. In this chapter, I argue that although this is the official Tablighi position on how faith is cultivated, Tablighis recognize that the ritual process is not sufficient to create "certain" faith. Tablighi recognize that regardless of how committed a Tablighi is to dawat and mosque activities, he does not spend all his time among Tablighis. He also lives in a world suffused with unIslamic practices, and these unIslamic practices constantly threaten the faith that he cultivates in dawat. What happens when he cannot escape these spaces of unIslamic practice? The Tablighi Jamaat congregation is the space in which one learns how to live piously, but there are also other spaces that bear on the question of piety, the question of faith, and the question of spiritual presence, most notably the environment of the home (ghar ka mahol). It is one's most close and intimate relationships that determine one's own ability to live in pious terms. One must ultimately create a spiritual home in order to live a pious life, and this requires that, like oneself, one draws one's own kin relationships, especially fathers, sons, brothers and cousins, into the movement as well. In this chapter, I show that piety is a social rather than an individual achievement, one that depends crucially on relationships with others, especially kin. When there is a disjuncture between the world of the home 
and the world of the mosque (masjid ka mahol), faith becomes precarious. Conversely, when contiguity is created between home and mosque, one cultivates certain faith.

\section{DAWAT AND THE CONSTITUTION OF A SPIRITUAL HOME}

It is well known that the greatest charge against Tablighis is that they abandon their families including their elderly parents, wives and children for long periods of time. For many non-Tablighi Muslims, even some who were of the Deobandi persuasion and were generally committed to making Pakistan a more Islamic society, dawat in the form of the Tablighi Jamaat was against Islam because Islam insisted that one's primary responsibility was to to one's family and anything that contradicts this could not possibly be authentic. The fact that Tablighis renounced their responsibilities to kin meant that they were not good Muslims. Tablighis are well aware of this charge against them and take it seriously. It is one of the central points that the Elders try to refute in their sermons. Tablighis respond to the charge by saying that while the Quran says one must care for one's family, dawat is the "greater practice" (afzal amaal) and that the efficacy of other practices depends on fulfilling the greater practice. By fulfilling the greater practice, Tablighis insist they bring spiritual and material well being to their homes. Dawat, then, is constructed as being for the family's well being.

A number of miraculous stories circulated in the Tablighi Jamaat about people who left their families only to discover that some great tragedy had befallen them. Rather than turn back these Tablighis placed their faith in Allah and returned to discover that Allah had taken care of all their problems. This theme draws its inspiration from the paradigm of Ibrahim (Abraham) and his wife Hajra. In the Quranic rendering of this story, Allah commands Ibrahim to leave his wife and infant son Ismail helpless in the 
desert near Mecca. In the desert, Hajra and Ismail are without water and suffering from thirst. In desperation, Hajra searches for help at the hill of al-Marwa and when she doesn't find any, she runs frantically to the hill of al-Safa. When she doesn't find any water or assistance there, she makes her way back to al-Marwa and continues going back and forth between the two hills. After 7 trips between the hills, the Angel Jibreel (Gabriel) appears. Jibreel stamps his feet on the ground, and water begins to gush out. This becomes the well of Zamzam. Muslims reenact this event by walking back and forth between the hill of al-Marwa and al-Safa during the annual Hajj pilgrimage, and Muslims throughout the world consider the water that flows from the well of Zamzam to be sacred.

Tablighis stories about leaving one's family because of Allah's command is directly or indirectly evoke this scenario. Like Ibrahim, they leave their families as Allah commanded of the Prophet Ibrahim and all the Prophets who follow him. The paradigm of Ibrahim's sacrifice also has another dimension that is relevant to Tablighi ideas about dawat. When the well of Zamzam springs up, other tribes of the region come to Hajra to request that they allow them them to stay and live off of the well, to which she graciously agrees. This is the origins of Mecca. It is in this community, brought into being through the miraculous intervention of Allah, that Ibrahim's son Ismail would marry and give birth to a line of Prophets, and it is from this line that the Prophet Muhammad would also be born. The story of Ibrahim's sacrifice and Hajara's prayers, then, is the tale of the birth of the community out which the Prophet would be born. The sacrifice of Ibrahim and Hajara, an act of pure faith, is then the fount —materialized in the well of Zamzam—for the creation of the Islamic community. Like Ibrahim, then, Tablighis imagine themselves 
to be leaving their families in order to draw Allah's power and to create, literally, a true Islamic community. Dawat is the fount of this Islamic community.

Tablighis insist that the gravest threat to the Islamic community is the ethical dissolution of the home, which is the surest sign of the state of moral chaos (fitna). Without fail, when one asks Tablighis to give examples of the corruption of the world, they refer to the ethical degeneration of kin relationships; parents are not fulfilling the needs of their children; brothers fight with one another over property; husbands divorce wives over minor infractions; wives have no regard for their husbands needs; children abandon their elderly parents and so on. As one Tablighis asked rhetorically, "when there is no peace inside the home, how can there be calm in the world outside?" Stories about husbands beating their wives or brothers usurping the property of another brother cut through both everyday discourse and are often directly addressed in sermons. In one sermon, Hazrat explained that there are only a few sins for which one is punished in this life rather than in the next. These include dishonoring the Prophet, bothering a pious helper of Allah (Allah ka wali), and disrespecting one's parents. “One should not even say 'ufh' to one's parents," Hazrat explained, voicing the sound one makes when one is frustrated and dissatisfied. "When parents ask you to do something, you should consider this a gift from Allah." In this statement, the Prophet, those close to Allah, and parents occupy similar structural positions as objects of respect and veneration. Just as one should occupy a position as a pious listener in relation to the Prophet, and one should assiduously listen to and meet the needs of one's parents. Similarly, just as the Prophet cared for his followers, one must show care, kindness and warmth (shafqat) to those who are younger and weaker, including children and women. On another occasion, Hazrat 
decried how men go home and their wives and children are terrified like a "wolf has come home." Hazrat explained that every time the Prophet came home, it felt like "the first day of spring." In countless sermons, I heard The Elders and older companions implore their fellow Tablighis to be kind to their wives and children and respectful towards their parents. This sentiment is captured in the oft heard refrain "respect for one's elders, and care for the young." Much like the relationships I described in Chapter 4, being ethical here entails recognizing one's place in a hierarchy and meeting the obligations that pertain to one's station. Hierarchy is organized around two axes: age and gender. The young and women must show respect to elders and men, while elders and men must show care for the young and women.

Tablighis say that it is only through dawat that the ethical dissolution in the home can be forestalled. Without Islam, families are destroyed. The reason that dawat engenders ethical relations is because of its disciplinary power. Tablighis say that by disciplining the lower self, dawat allows a person to live in ethical terms with one's family. Dawat, they sat, creates a "softness of temperament" (narm mizaaj), which makes one care for the well being of others, and a "coolness of temperament" (thanda mizaaj), which allows one to contain one's passions and anger. Softness and coolness of temperament are both qualities of the spirit, as opposed to hardness and hotness, which are associated with the lower self. By embodying these qualities, one creates the love in the family that draws others to Isalm as well. Hence, just as a Tablighi is a conduit for divine words, a Tablighi is also a conduit for morally laden affective dispositions that bring one's kin to Islamic practice in order to create a spiritual home. 
Take for example, Abdul's description of the transformative power of dawat in his family. According to Abdul:

I was the first in my family who committed to tabligh. Now, Alhamdulillah, many people have committed. Allah has taken much work from us. Many family members have done three-days, forty-days, four-months. Alhamdulillah, women have started doing pardah. You came to my house that day. Did you not see that it there is a religious environment in my house? You saw an environment of pardah. You did not see any women come in front of you. It was not like this before. Now, Alhamdulillah, the whole family is like this. Even in family parties it is like this, ladies separate and gents separate, and in the ladies section, there will be lady waitresses, not men. They feel good about this, especially the ones who do pardah, otherwise they feel in a lot of pain if a man comes in.

In this quotation, Abdul stresses the rise of Islamic practice in his family with the stress on dawat for men and pardah for women. He claims it spread from his immediate home of his father and brothers to his extended kin of uncles and cousins. The implementation of pardah has now extends across the family and family events like weddings are gender segregated. When I asked Abdul if he encountered any resistance from his family, he explained that in the beginning there were many who were against dawat. He said that his own father was opposed to him going on dawat, but now he thinks that Tablighis are "ideal people." "My father now says [to others], 'I have become too old to go but please take my children.' By Allah's grace, he is happy when we go, he prays for us, he tells us to pray for him, and he worries if we don't go." I asked Abdul why he thinks people are opposed to dawat in the beginning. He explained:

They think that he is not a person who does work. They think that 'the world' is everything. They think that if we don't work, how will we eat. They have forgotten that when you are born, you do not do any work. For twenty years, a person is mostly studying and does not really do any work. Who is feeding a person for those twenty years? Allah is feeding you! Who puts love in the hearts of mothers and fathers? Allah puts love in their hearts. Who puts the passion in 
parents' hearts that they must nurture their child, that one must care for the child, buy the child's clothes, feed the child? Who puts this love in their hearts? Allah puts it in their hearts. If that same Allah takes away that love, then one is tested. If a person stays on the religious path, then Allah leaves love in their hearts.

In this quotation, Abdul notes that it is Allah who puts love in the hearts of parents, which sustains a child into adulthood, but Allah only keeps love in their hearts if they are fulfilling their religious duties. According to Abdul, his father's transformation from being opposed to dawat, to recognizing its virtues, to becoming a strong proponent of dawat is made possible because dawat makes Allah put love in people's hearts. Note that this "love" is the same concept that shapes relationships inside the congregation, which I noted was not about equality but submission. Here, however, that same term implies both submission to authority and the capacity to care for and nurture those below oneself. This love sustains the family just as it does the religious community because it allows grants the capacity for those below (women and the young) to submit to those above (men and elders) and for those above to care and nurture those below. This is the basis for an Islamic home.

I was told that if I committed myself to dawat, I would also see its effects in my own life. I often used my own family to explain to others why I could not come on this trip or that trip or commit to this or that task. This was not entirely untrue as my mother was deeply worried that the Tablighi Jamaat would become an untoward influence on my life, and that it would pull me away from my work. Once I told Talha that my mother wanted me to shave my beard, which was something she had jokingly said to me on more than one occasion. Talha responded by telling me how his uncle (mother's sister's husband) was furious at his son, Asher, when he would go to the shab-e-jummah. On one 
occasion, Talha said, his uncle showed up at the grand mosque and in the middle of a sermon began yelling at Asher and dragged him away, forbidding him from coming back to the mosque. Talha said that as Asher himself came to be transformed through dawat, his father gradually came to see the virtues of Islamic practice. His heart was "softened" and "opened," and love descended in his heart. "If you walk with the love of the Prophet in your heart, Allah will put love in the hearts of others." Such a statement makes clear that genuine practice plants the seed of desire and affect in others.

Now, we can see that although religion and the world, sacred and profane are conceptually distinct, Tablighis see a substantive flow of virtue from the former to the latter. This is a direct analogue to the relationship between the spirit and lower self. By bringing the spiritual/religion and material/worldly spheres into a proper relationship, both "worldly" and "spiritual" well-being is created. It is the flow of Islamic virtues from the sphere of religion to the sphere of the world, from sacred to profane, that creates an Islamic order. As he is transformed through the practice of dawat, a Tablighi comes be a conduit not only for divine words but also a vehicle for affective dispositions like "love" that reconsitite familial relations. One Tablighi, Aslam Bhatti, explained how dawat allows one to transcend the seemingly intractable problems of kinship:

You know, the mosque is like a store. You have to go to the store and pay to acquire what you need. Similarly, you have to give energy, wealth, and time (jaan/maal/waqt) to the mosque to receive Allah's grace ... When you have Allah with you, and your wife asks you to go out for shopping, but your mother wants you to stay home, then you are able to make both of them happy, but when you don't have Allah on your side, then you can even given whatever they want, and they will still be fighting! 
This quote draws on a widely recognized and richly dramatized contradiction in South Asian, especially North Indian, kinship between mother-in-law (saas) and daughter-inlaw (bahu), a fact that emanates from virilocal residence. As is well known, wives move into their husband's house where they are expected to carry a great deal of the burden of domestic work. Many wives try to find ways to draw their husbands away from the parents' house in order to constitute a separate home, exacerbating relations with her inlaws. Aslam Bhatti sees dawat as a means to transcend these tenions within kinship. I heard a range of such examples that focused on a wide variety of conflicts between husbands and wives, fathers and sons, brothers and cousins. In these narratives, one is given the image of a Tablighi travelling from mosque to mosque, further and further afield from one's home, purifying one's own heart and acquiring Islamic virtues, only to return to one's home to be able to gift these virtues to one's kin, who then find themselves doing practice and each and every person comes to realize ethical ideals of kinship. It is in this sense that a spiritual home is constituted.

In Tablighi ideology, the transformation into a Tablighi most directly influences those closest to oneself, especially those with whom one lives. From there, Islamic virtue will spread to friends, neighbors and colleagues. But, just as a person must be willing to be "acted upon," kin must also be willing to be acted upon. Indeed, story of Ibrahim and Hajra, Hajra gives her assent to Ibrahim as act of faith. She tells Ibrahim that if it is Allah's command, he must leave them. Hajra may be seen as standing in for the home itself, and this account foregrounds need for cultivating the receptivity of the home to Allah's will. We might ask, though, what happens when this receptivity does not exist? What happens when one's kin reject the gift of divine vitality (barakat) that brings well- 
being (khair)? What happens when one kin refuse the spirit of Islam? In the next section, I show that when the home lacks receptivity, then a person's faith cannot be secured. Let us now return to the example of Umar.

\section{PRECARIOUS FAITH: DISJUCTURE OF HOME AND MOSQUE}

The Tablighi Jamaat's annual congregation (ijitma) in Raiwind, Pakistan is one of the largest gatherings of Muslims anywhere in the world with hundreds of thousands if not millions of attendees. The congregation is hosted in a massive tent city that stretches for several square kilometers. Men from across Pakistan, old and young, rich and poor, and from every conceivable ethnic and linguistic community attend the annual congregation. I attended the annual congregation in both 2010 and 2011. A few years earlier, the annual congregation had been split into two separate back-to-back congregations, one for Pakistani Tablighis and the other for foreign Tablighis, because the facilities could no longer accommodate the enormous crowd of attendees who came from both Pakistan and around the world. There are also slightly smaller provincial congregations throughout the year. The congregation begins on a Thursday, just like the shab-e-jummah and ends on Sunday morning after the collective prayer, which is said to be especially meritorious. Tablighis spend three days giving and listening to sermons and conducting daily Islamic prayer and practices at the annual congregation. Just like the shab-e-jummah, the annual congregation is organized into locality, cities, and regions. One stays with one's own mosque and is surrounded by mosques from one's own locality.

In 2010, after our 10-day tour, we arrived at the annual congregation. Our travelling group which consisted of people from several different mosques dispersed to 
each of their respective mosques. Talha went to the quarters of the Elders, where he stayed to tend to Hazrat's needs. I stayed with the Al-Aqsa mosque as their guest. However, I made sure over the course of the three days to seek out the other Tablighis of our group in other mosques. I tried to track him down Umar, as I felt closest to him. I called Umar and asked him if I could join him at his mosque, and he said of course but that he was busy running around and would come get me when he could. Over the next two days, I tried calling him and each time he would tell me he would come get me a little later, but he never did. On the last day of the congregation, after calling him several times, he responded, and invited me to his mosque.

When I arrived, Umar welcomed me but immediately suggested that we should go for a walk, to which I agreed. At the time, I had not thought anything of Umar's eagerness to leave the space of his mosque, but in retrospect, after my repeated attempts to meet him at his mosque, I can say that Umar was trying to keep me from becoming too familiar with the Tablighis of his mosque congregation. As we walked towards the pathway that divides the sections of the tents, we encountered a short middle-aged man who Umar greeted warmly. Umar introduced him to me as Imaad bhai his "leader" (amir). Imaad bhai seeing an opportunity to give dawat requested that we sit down. I sat cross-legged but Umar sat in a kneeling position. Umar told me that Imaad bhai had been the one who first gave him dawat and brought him to "Allah's path." As he said this, he bowed his head just slightly, enough to mark deference and to mark that he was making himself receptive to the act of dawat that he knew was about to commence. Imaad bhai said that Umar was quite "wayward" (bigra hua) when he had first started dawat and didn't listen to anyone. He always wanted things to be "his way." Gradually, he said, this 
all changed as Umar started coming to the mosque more frequently. Sometimes he would come to the mosque every day, he explained, and spend all day in practice, but then you would not see him in the mosque for several weeks. We were always worried about him, Imaad bhai explained. He did this for a long time before he finally started coming regularly and started sitting in the "everyday ties." As Imad bhai described this process, Umar's gaze remained fixed on the ground. Umar did not speak on his own behalf, which is itself a telling feature of the Tablighi congregation. Not only was he making himself available to listen to dawat, but he was also placing his own narrative in the hands of Imaad bhai, who was explaining to me what Umar had gone through when he first began dawat. As Imaad bhai told Umar's story, Umar would nod as if he were remembering those events. Imaad bhai then said, "See, nobody knows what a person is going through . .. what sacrifices a person has made."

This last sentence seemed to come from nowher and suggested that there was much that he was going to leave unsaid. Imaad bhai's use of the term "sacrifice" carried an added emotional weight and a deep sense of loss that I could also see on Umar's face. As I moved through my fieldwork, I was able to reflect back on the sense of sacrifice, hardship and loss that people like Umar experienced when they committed to dawat. While the discourse of the Tablighi Jamaat says that commitment to dawat will have a transformative impact on one's kin relationships, and Allah will put love in the hearts of one's kin, this is far from the case in many situations. In fact, dawat quite often creates great strain in one's family with a person regularly having to battle with those closest to them, to stay inside the Tablighi congregation. This experience weighed heavily on many Tablighis I encountered. Over the course of my research, I came to recognize this sense 
of loss not only in Umar but in many other committed Tablighis as well, an underlying sadness that bubbles up when they speak about sacrifice. This sense of loss springs from an experience of rupture with their kin. But, the sense of loss was not shared evenly across the congregation. For some Tablighis, participation in dawat was strongly opposed by family members, while for others it was accepted and even encouraged. Still others were participating in what was clearly a family tradition in which their whole family was involved. Umar's uncertainty and doubt about his own faith, I learned, came from the rupture between the home and the mosque. If the condition for rising up in the movement is to spread Islam first to one's close and more intimate relationships and then beyond that to those more distant, the failure to do so is experienced as profound doubt and uncertainty in one's own faith. This is what I refer to as precarious faith.

First, let us return to the question of loss. The experience of loss so common in the movement did not surprise me. As I explained in the introduction, Talha had rather abruptly cut all of his relationships with his friends, including me, when he joined the Tablighi congregation. The experience of seeing such a close friend remove himself entirely from his social network was one of the primary reasons why I was interested in the movement. Our mutual friends and I would frequently mention Talha in our conversations. A few friends had reached out to him but to no avail. Occasionally some mutual friend or another would run into him somewhere and try to arrange for us all to hang out, but these meetings never materialized. It was clear that Talha was keen on cutting off his old ties in order to build a new social network inside the Tablighi Jamaat with people who he deemed to be living within the parameters of Islam. It was only 
many years later that Talha and I reconnected in Karachi when we ran into each other that the Tablighi mosque complex.

Talha's story represents an extreme case in which a person had to disassociate from his friends and turn the Tablighi Jamaat into his primary friends' network. Few other Tablighis that I encountered had to take such drastic measures, though stories about the "sacrifice" that such people made were commonly invoked in Tablighi discourse. Many Tablighis I encountered came from families that accepted the doctrines of Deobandi Islam, even if they were not involved dawat. Even in these circumstances, almost everyone told me how they had to change their lives when they joined the congregation, and how they had to adjust their friendships such that they remained inside the "boundaries" (hudood) of Islam. Mostly they meant that they had to avoid certain kinds of male humor, especially of the explicitly sexual variety, and they had to refrain from using foul language. But, Talha's rupture was more dramatic than this. He literally had to disconnect from friends who had been very dear to him for a very long time, and this loss weighed heavily on him. This was betrayed by his eagerness to discuss our old friends and lives and in his effort to reconnect with at least those to whom he was closest. Talha recognized that his loss was a burden that he had to carry if he wanted to live in the Prophet's way.

When Talha and I reconnected, I was surprised at how eager he was to help me with my project. I thought he would object to its premises, and I also worried that he might tell others not to engage with me. But, I came to see that my presence in the Tabligh Jamaat was, in many ways, an occasion for him to recover some part of a life that he had lost when he removed himself from his own friends. Talha and I spent a great deal 
of time discussing issues pertaining to the Tablighi Jamaat, but we also frequently recollected old memories and reestablished an old friendship. The experience of reconnecting with me through my project also led Talha to reconnect with some of our mutual friends. We all gathered at an old friend's house on two occasions and all went out for coffee. Talha attended one event for the wedding of one of our close mutual friends after I left the field for the US, and when Talha got married he invited a few of our friends to his own wedding. I once asked Talha why he had disconnected from his friends, and he explained that it was all very difficult for him losing his friends, but he stated unequivocally that our way of life was "way outside of Islam" and that, in order for him to find has way back to Islam, he needed to separate entirely from the life he had. When I asked how he felt about reestablishing old ties, he explained that he had now been a Tablighi for almost a decade, and his faith was much stronger than it was then. This meant that although he still had to avoid unIslamic activities, it was easier for him to be around people who were not entirely "religious" without losing his own way.

Talha did not even attempt to draw his own core group of friends into the movement because he saw us as being irredeemable at the time. He felt that any such engagement would simply undermine his own faith rather than benefit us. But, he had many cousins on both his maternal and paternal sides htat were committed Tablighis, and he even reconnected with an old childhood friend who had joined the movement independently of him, so he was able to build a network with some ease. Neither his brother nor his father were actively involved in the movement, but his father, in Talha's own narrative, had come to see the importance of dawat over time. Indeed, he had grown a beard and was himself a devoted follower of Hazrat, even if he did not go out on 
preaching tours. Talha's mother and sisters mostly practiced pardah, the strictures of which were much looser before Talha became a Tablighi. Talha's younger brother, Raza, never joined the movement, and this remained a source of contention in the household. My understanding is that their relationship became contentious when Talha first started practicing dawat, but over the years, the two had established an understanding that involved less and less interference in each other's life. When I first saw Raza after many years, I asked him why he was not involved in dawat. He jokingly remarked, "Some people have to live in this world too!" However, although Raza did not live up to Tablighi ideals, he did pray regularly and the more I met him, the more it was clear that he had a generally favorable impression of the dawat and saw it as a central part of Islam.

What I am suggesting here is that Talha had managed to convince his immediate family, his father, mother, brother and sisters of the merit of dawat. He had successfully managed to create a context inside his home that allowed him to continue his rather demanding life in the Tablighi Jamaat more generally and specifically his dedication to the world of Hazrat's spiritual house. This is no small achievement. Talha often left home for several days consecutively in order to attend to Hazrat's needs in the spiritual house. He would go directly to work from the spiritual house and return to the spiritual house, only coming home to pick up clothes or to eat dinner. This meant that his family had to assume many of the day-to-day responsibilities like collecting groceries and paying bills that otherwise might fall on his shoulders. It is seems reasonable to me that, in his absence, much of the responsibility that would otherwise be shared between the brothers had now fallen on Raza's shoulders, which might have been some of the grounds for tension between them. And yet, despite these limits, Talha had managed to convince his 
immediate family that what dawat was meritorious and necessary work and even elicited their support and encouragement.

While Talha's story represents a rather extreme case of rupture with friends, he did not experience the same rupture with his close kin who generally accepted what he was doing. This is at least partly because everyone in Talha's house accepted the basic position of Deobandi Islam that demands replicating in one's life the Prophet's ways. For people who already accept this premise, the argument needs to only be made that dawat itself is a fundamental practice of the Prophet. This created a fertile ground for the receptivity of dawat in Talha's family. And, this is a common story for many Tablighis, especially in places like Karachi where Deobandi understandings of orthopraxy are themselves quite pervasive. Like Talha, many Tablighis already came from families that accepted the Deobandi stress on the Prophet's example as a means for the cultivation of virtues. What was necessary for these Tablighis, like Talha, was to extend this logic to dawat by placing it at the center of the Prophetic model.

In the narratives that Tablighis, the family is first reluctant to endorse the Tablighi's participation in dawat but gradually come realize its value when they witness a positive transformation in the person. When Tablighis are pressed on what specifically creates this transformation in others, they invariably point to the fact that Tablighi creates the pious qualities (sifaat) that make one "soft" and "open" and thus kind to family and receptive to their needs. These qualities allow a Tablighi to show kindness and care (shafqat) towards those below like women and children, and respect and receptivity (izzat) to those above. For instance, one Tablighi told me how, before he joined the Tablighi Jamaat, if his wife did not bring his breakfast to him in time, he would be 
furious and scold her, but after he joined the Tablighi Jamaat, he would wait patiently, and even if it was an hour late, it was no problem. Others explained to me how their parents were not very happy with them because they are now willing to meet all their expectations without the slightest resistance. When kin see these virtues in a Tablighi, they too are inspired to embody these virtues, and they then become supportive of Islamic practice for others in the household as well as for themselves. In the Tablighi idiom, Allah "softens" and "opens" their hearts and allow love to settle in. Although the transformative power of dawat is often attributed to Allah's power, one cannot deny that many Tablighis make an extra effort to demonstrate the merits of dawat to their families by devoting extra time to the house and acting in accordance with kinship ideals so that there families come to see the value of dawat. In this sense, we can see once again that by embodying Islamic signs, Tablighis come to assume responsibility for the ethical entailments and expectations of these signs, and therefore they come to act in keeping with these expectations. In the home, this means living up to kinship ideals.

But, this is not always the case. Let us return to Umar's story and his experience of rupture. In many ways Umar represented the opposite position to that of Talha. While Talha's friend's network was by and large made up of people who were not particularly committed to Islamic practice, or as he put it "way outside of Islam," his family was more or less Deobandi. Talha explained to me how, when he was out at a party and mixing freely, he never felt that what he was doing the right thing, and he always felt that if his family had known what he was doing, they would have disapproved strongly. He would narrate that past as one in which he experienced constant rupture between the world of his home and kinship and the world of the outside with his friends. This might explain 
what I described as Talha's calm and quiet demeanor. It was when he joined the Tablighi Jamaat, he said, that he found that inside and outside were finally in harmony. Umar, on the other hand, came to the Tablighi Jamaat through his own friends' network, friends he had made through the domestic cricket circuit. Many prominent Pakistani crickets have joined the Tablighi Jamaat, and they have had a tremendous influence evident on the culture of cricket. Besides Umar, I met two other Tablighis who played club cricket at this level, and they too looked to these prominent national cricketers as icons. Unlike Talha, who had to disconnect from his friends, then, it was Umar's network of friends who he had developed through years of playing cricket that were instrumental in inspiring him to commit to dawat.

However, Umar's active participation in the Tablighi Jamaat was strongly disapproved of by his family, especially his father. Umar's family was of the Barelwi denomination, which stands opposed to many of the core teachings of the Deobandi tradition. In the next chapter, I will more thoroughly explain the sectarian conflict between Deobandis and Barelwis, but for now it is enough to note that Barelwis maintain a strong commitment to the veneration of Sufi saints at their shrines. As I described in Chapter 2, this veneration of saints entails a commitment to the Theory of the Light of Muhammad, a theory that the Prophet was made of Divine Light and that this light is transmitted through the Prophet's lineage, a conception that conflicts with the Deobandi commitment to orthopraxy. Umar never discussed his father or family's opposition to his participation in the Tablighi Jamaat, but others told me that Umar's family were Barelwi and did not support his participation. One Tablighi described them as being deihati a term that literally means "rural" but also carries the connotations of being simpletons who are 
easily manipulated by false religious leaders. The contrast between a scripturally grounded "urban" Pakistan and a "rural" religiosity, understood as idolatry, of saint worship was a common theme in the Tablighi Jamaat. "The village people's religion is in the hands of city people," was a statement I heard several times from the pulpit. In this sense, describing Umar's family as "rural" carried with it the connotation that their religiosity was anchored in false and corrupted forms of religiosity, and that they were not proper Muslims. Umar's inner conflict was tied directly to this issue.

This came to my attention on our tour (gasht) in Multan. While conducting dawat in a college dormitory, Umar and I stumbled upon a young Barelwi teacher who was a resident assistant in the dormitories. The young teacher, a thin man with a dark complexion and a short beard, invited us in to his room to "discuss" religion. Umar began to give dawat with his usual flair, explaining how when mosques are full, prisons and mental asylums are empty, and when mosques are empty, prisons and mental asylums are full. With one minute of the dawat, the young teacher abruptly cut him off. "This is all fine. This is all fine," the teacher said. Umar was forced to pause. The teacher then proceeded to ask how it is possible that the Prophet did not have knowledge of the unseen (ghaib) when the Quran explicitly says so. This is a central theological disagreement between Barelwis and Deobandis with the former insisting that Allah had granted the Prophet knowledge of the unseen, while Deobandis claiming that only Allah has such power. Behind this disagreement is a deeper question about the nature of the Prophet and whether he shares in God's essence (monism) or whether he is ontologically separate from God (dualism) (see Parkin and Headley 2000), which in turn has implications for whether the Prophet can intercede on one's behalf by moving between these realms. 
Umar quietly listened as the teacher made his case, a case with which Umar was clearly familiar. When the man finished, Umar responded by positing the conventional Tablighi response to sectarian division, which is that these are debates between the "ulema and that we need to focus on what was common between Muslims. The man agreed that there was much in common and after which we departed.

I asked Umar what the teacher was referring to and he sidelined the question by saying that he is a Barelwi and repeated the claim that there are some differences but did not elaborate. It was not long after this that Umar became what Talha described as "dried up" (khushka), spending hours in solitary reading and recitation. I would not have thought that there was any relationship between this event and his solemn behavior if it were not for what I noticed about Umar on a few occasions when the Deobandi and Barelwi disagreements surfaced, which they did quite often. On another occasion, we sat around the mosque courtyard about 15 minutes or so before the evening prayers when the sounds of a naat, a devotional song in praise of Allah, became audible. Tablighis are torn about the power of such devotional songs, seeing them as both powerful and capable of drawing Muslims to Allah and a potential distraction from real worship. Tablighis insist that the naat is acceptable under limited circumstances and that too that it should be focused exclusively on Allah and not on the Prophet, while many Barelwi naat evoke the power of Prophet to intercede. A few Tablighis began to joke about how Barelwis confuse music for worship and asked Allah to give them guidance. Umar was visibly troubled by all of this, his head bowed and his lips moving in scriptural recitation. I suspect he was asking for guidance. 
One conversation in particular between Umar and Abdul brought Umar's inner conflict to the surface. It was 12 Rabi-ul-Awwal of the Islamic calender, a day that Barelwis and other Sufi-oriented Muslims treat as the day of the Prophet's birth or Eid-eMilad-un-Nabi. For Barelwis, this is a festive occasion in which green tinted lights are hung over streets and on houses and gates, and in which Muslims of all kinds, especially Barelwis distribute food, hold processions, and sing naats. Deobandis consider the celebration of the Prophet's birth to be sinful and the invocation of the Prophet to be tantamount to idolatry as it elevates the Prophet to the status of Allah. A few week earlier, Hazrat had passed away, and Abdul and Umar had decided it would be a good day to visit his grave and pay respects, and they asked me if I wanted to come along, to which I agreed. We congregated at Abdul's house, where we had lunch before departing for the graveyard. As we waited on lunch to be prepared, Umar asked Abdul why the celebration of Eid-e-Milad-un-Nabi was considered so contentious. I found it strange that someone who had spent so much time in the Tablighi Jamaat would ask a question that was rudimentary to people of the Deobandi persuasion, and I wondered why Umar felt Abdul might have an authoritative answer when he had spent no more time in the Tablighi Jamaat than Umar himself. Abdul went on to explain that in Islam, we do not celebrate birthdays and that this is a Western custom. He said that one should only remember the day of death. Some 'ulema, he noted, say that 12 Rabi-ul-Awwal is actually the day of the Prophet's death or "return" (visaal), and should be treated as a somber occasion, not a celebratory one. Umar knodded. "But maybe it's still acceptable because it reminds people of the Prophet," Umar asked. It was apparent that Umar was sidelining the deeper theological disagreements and trying to fold the Barelwi and Sufi-inspired 
celebration into a Deobandi framework. Abdul glanced at me, and both of us could sense Umar's concern and contrition. “Allah knows best. May He give us all guidance,” Abdul said in a sympathetic tone.

The uncertainty and ambivalence of Umar stood in marked contrast to the certainty and authority expressed by Abdul even though both were old companions. Umar was clearly asking questions that he had to answer for himself. He had to answer them because they could not be simply dismissed. They came from his close kin and likely from his own father. The contrast between Talha and Umar, then, is striking, because Talha could distance himself from his friendships and eliminate the voices that intruded, asked questions and raised doubts. Umar could not sideline such theological debates because they were constitutive of his home. His kin rejected some of the foundational premises of the Tablighi Jamaat, which created a radical disjuncture between the space of the home and the space of the mosque, and the latter was always intruding in the former. The failure of receptivity on the part of his kin was a great source of concern and contrition for Umar who was always trying to find ways to bring them to a better understanding, but his failure to do so generated anxieties, doubts and sadness in him. This experience of rupture was registered in him as precarious faith, a faith that was constantly in need of repair and restoration, which is what Umar was trying to achieve in his intense bouts of reading and recitation.

It should be clear from this discussion of Umar that piety far from being an individual achievement depends on the receptivity of the home, which is the space of one's close kin, especially one's father, mother, brothers, sisters and wives. If we think back to our discussion in Chapter 3 about how ritual is cultivates faith,, then here it is 
clear that the efficacy of ritual depands on factors that extend well beyond the ritual act itself, into domains beyond what we conventionally see as "religion" into the sphere of what we classify as "kinship." If we consider that central to the idea of becoming a pious subject is becoming a channel for the words of pious others, then relationships that stand in contrast to the Tablighi discourse, like those of Barelwis, make the realization of piety impossible or at the very least very difficult. Indeed, what I have described as Umar become intensely focused on ritual and what Talha referred to as Umar becoming "dried up" was his effort to secure his own faith that was constantly threatened by the voices of his intimate others, his family, and to draw on the power of ritual to transform his family. His family's acceptance, however, remained elusive and his faith, therefore, remained precarious. Let us now turn to those for whom faith is certain.

\section{CERTAIN FAITH: CONTIGUITIES OF THE HOME AND THE MOSQUE.}

Irfan was the amir of the traveling group that I accompanied from Karachi through Multan to the national congregation. Many of us continued to jokingly refer to him as amir sahib from then onwards. Irfan was a short, pudgy and light skinned young man in his mid to late 20s. He had a warm and hearty laugh and a high-pitched voice, and, like many Memons, he spoke very fast. He was exceedingly polite, always taking great pains to welcome me and make sure that I was doing well. Irfan was a permanent fixture in the evenings at Hazrat's spiritual house, where he always conducted service (khidmat) responsibilities like serving food and caring for the needs of visitors. Irfan was seen by many to be a model Tablighi, not only willing to do work but also exceedingly humble in his demeanor, only assuming a position of authority relative to others when it was demanded of him. He was always situating himself as a pious listener relative to 
those more experienced than him. Irfan seemed to embody what Shahzaib had described to me as the most virtuous quality of the Elders, that they were so pious that they did not seek any recognition at all.

If Umar represented one end of the spectrum of people who break from their family traditions in order to recreate themselves as Tablighis, Irfan represents precisely the opposite end of the spectrum; Irfan's father, Hafeez bhai, was one of Hazrat's primary and oldest caretakers. He had been involved in the life of the spiritual house since its founding in the mid 1990s. Irfan's paternal uncle was the amir of the Al-Aqsa congregation, and the youngest uncle was involved in the Al-Aqsa mosque committee, where he could advocate for Tablighis. All three brothers lived together in a three-story house in which each brother occupied one floor located a few streets from the mosque and spiritual house. All of their children had some form of training in the Islamic sciences, whether they were studying to be 'alims (scholars) and muftis (legalists) or they were haafiz-e-Quran, those who have memorized the entirety of the Quran and thus are often prayer leaders. Irfan was also a haafiz. Along with their training in the Islamic sciences, the entire family was deeply involved in the life of the mosque and Hazrat's spiritual house. They also frequently hosted naat recitations on their roof. In other words, the Hafeez family was at the center of the Islamic life of the Al-Aqsa area.

Irfan was also very close to Talha. Over the course of my fieldwork he and I developed a cordial and friendly relationship. Irfan would jokingly refer to me as an “elder" after I grew my beard, not to the Tablighi length, but enough that it was seen as a substantial beard. For Irfan, as for many others, this beard marked my progress towards becoming a Tablighi. While Umar's jokes ranged from jokes about me speaking English 
to my lack of commitment to dawat, Irfan mostly joked about how pious I was becoming and how much progress I was making. He always meant to be generous in his approach, even in his jokes. This was actually very similar to how Hazrat himself treated me in the hope that it would inspire me to make a more firm commitment to dawat. Many Tablighis commented on Irfan's unique ability to keep all his relationships within the bounds (hudood) of Islam, and I think, Irfan's form of joking as well as his constant encouragement were part of what registered to many people as being reflective of his faith and piety. The jokes were themselves a form of dawat.

I had asked Irfan on a number of occasions to help me with my research, and like others he said I just needed to keep coming to the mosque and spiritual house, and I would learn all that I needed to learn. I insisted though that he let me interview him, and that it would help the process along, and he agreed, but he kept putting it off until shortly before it was time for me to leave for the US. I suspect he thought that if I got my interview, I would stop coming to the mosque. A week before I was ready to leave, I managed to sit down with Irfan for the interview. Irfan explained to me how his family all came to the Tablighi Jamaat. Irfan explained that his paternal uncle who is younger than his father drew his father to dawat, and together, they brought their father to dawat as well. Irfan remarked "When we were born, Alhamdulillah, there was already religion in our whole generation." Irfan's narrative was one I had heard many times before, a story of how one person's religious awakening spread to all the members of his family and then all subsequent generations were born inside a religious environment. 
I asked Irfan what the difference is between people like him who are born into a religious environment (dini mahol) as opposed to those like Umar who have to create it themselves:

Those who come to religion on their own, who start from zero, they are more important [to Allah]. Those in my category have less importance because they have always been in that environment, but those who start at zero, they have nothing, and they suddenly come in religion, they understand the value of religion. This is why if you see Muslims abroad ... those Muslims are such that you will say, 'this is a Muslim' . . because this person has lifted himself from the step of zero and brought himself to religion. He has borne the cost. People like us have been Muslim since childhood, we've been in tabligh since childhood, so we do not see its value. .

In this quotation, Irfan is rehearsing the pervasive idea in the movement that Allah rewards those who make sacrifice for him. Muslims living abroad, by which he means those living in unIslamic environments, remain Muslim through their sacrifice and determination, and for this Allah rewards them. Note that in Irfan's remarks, the person who gives great sacrifice is not only important to Allah but also recognizes the value of religion in a distinct way. His sensibilities are honed such that he knows the difference between right and wrong. This is because, for Irfan, religion is itself an ethical disposition that Allah grants those who are important to him. Thos who start from "zero" but come to practice through their own volition are both valued by Allah and recognize the value of religion. In this formulation, people like Umar represent an ideal.

Paradoxically, however, while those like Umar are highly valued, they are not in a position that is easy to sustain. Irfan explained that while those who have grown up in a religious space might not see its value, they are habituated to living their life in religious terms. "While we might not always see its importance, there is the benefit that if a person 
has lived in this environment from the beginning, it's easier for him to keeping walking in this path. This is why the percentage of people of who have completely changed are fewer than those who come from homes where there is already religion." In this quotation, Irfan is suggesting that people who have grown up in an Islamic environment are habituated to Islam enough that they do not even need to make an effort. On the other hand, those who come to Islam through their own volition must struggle to stay within the parameters of Islam. While Tablighis celebrate people who are able through their own will to transform themselves, they insist that the goal of the movement is to create such an environment (mahol) that being religious (dindaar) becomes easy and even unconscious. It is in this second sense that those, like Irfan, who have been raised in what Tablighis deem a "religious environment" (dini mahol) are the ideal.

While facing hardship is laudable, Allah gradually makes it easier for one to do one's practices and live an Islamic life. But, this process requires drawing one's kin to the congregation, and this requires Allah's assistance. "When you take one step towards Allah, he takes two steps towards you," and "Allah opens paths," are statements Tablighis repeat constantly. It is widely recognized that some of the most significant obstacles to participation in dawat is the response from one's own kin. I was constantly watching Tablighis explain to newcomers how they should just make the "intention" (niyyat) and Allah would make everything else fall into place. Tablighis recognize that it is only by soliciting the support of one's kin that one's ability to do dawat becomes secure. Otherwise, one might become intensely passionate for Islam but that passion dissipates and eventually one is back to living an unIslamic life. It is by creating a channel between the mosque and the home that faith becomes secure. The connection 
between the mosque and the home is institutionalized in the daily "reading" (taeleem) from the central text of the Tablighi Jamaat, the Fazail-e-Amaal (The Virtues of Practice), which must be conducted once inside the home with one's family and once inside the mosque with fellow Tablighis. Tablighis understand the "reading" to create religious environment in the home, which then propels one to leave the home for the mosque for prayers and for dawat tours.

Irfan's narrative about how his family came to the dawat reflects precisely how, under ideal circumstances, a spiritual home is created. The narrative begins with his youngest uncle, father's younger brother, who then inspires Irfan's father and the other brother. Noticing the positive effects of spiritual transformation, their father, Irfan's paternal grandfather, also accepts dawat into his heart. Note here how the spiritual dissemination actually moves from the younger generation to the older, and within the younger generation, it is the younger sibling who spreads the dawat to older siblings. It moves from the originator through a series of links, the brothers, to the father, in a manner that is precisely the opposite of genealogical lines. Drawing one's brothers into the movement was seen as being of utmost priority for those whose brothers were not committed Tablighis. These Tablighis would repeatedly ask other members of the congregation to speak to their brothers to bring them to the mosque. Some even asked me to speak to their brothers, and bring them to the realization of the importance of dawat. This "concern" (fikr) for brothers is based on the belief that if brothers are united in Islam, then Islam can easily spread to the rest of the members of their family. This becomes all the more important because one cannot preach directly to one's father as that would violate the proper order of authority in the house, potentially creating conflict and 
turning one's father against the congregation. Hazrat explicitly forbade Tablighis from preaching directly to their parents because this could undermine the very possibility of bring them to dawat. Hazrat insisted that one should focus on one's own practice and pray that Allah brings one's parents to practice as well. One should become an "example" (misaal) to parents so that they themselves come to Islam. With older brothers, the gap was less significant, and therefore one could potentially preach directly to one's older brother, but Hazrat insisted that one should even do this with caution. Preaching to younger siblings was understood as much easier. The idea here is clearly that one should work within hierarchies of age and gender, thus one brings those higher up to dawat not through direct preaching but through the embodiment of kinship ideals of respect and care.

Irfan's family was a model Tablighi family. I found there to be something undeniably practical about this ideal. The division of labor inside Irfan's family allowed one brother to devote time to Hazrat's spiritual house, another brother to give time to the mosque, and still the youngest brother to care for the family's business and property. Combined, the brothers and their children also contribute a considerable amount of time and resources to the day-to-day functioning of the mosque. At major Tablighi events like shab-e-jummah and especially at the annual congregations, the labor of the brothers and their many children is on full display. At the annual congregation, Irfan, who doesn't have brothers, and his many cousins contribute a great deal to the organization of the trip. Indeed, I found that many of the mosques I visited often clustered around a few key families. Many of these families represented three generations of Tablighis, like Irfan's 
family. Those Tablighis who do not have kin desperately seek to draw in their brothers and cousins, and create their own Tablighi families.

Beyond the practical advantage kinship, it was the very presence of kin inside the congregation that came to stand in as a symbol of a spiritual home. Tablighis practice strict norms of gender segregation in which the home is seen as the "inside" that is hidden from the view of outsiders. Tablighis do not really know what is happening inside the homes of others and it is often stressed that prying into the lives of others was fundamentally unIslamic. I had little access to the space of the home for precisely this reason. Despite these limitations, I know from personal experience that rarely is the world of the inside ever as orderly in the Islamic sense as Tablighis portray it to be. Tablighis, like everyone else, have complicated kinship lives in which kin have varying degrees of commitment to Islamic practice. I knew that many Tablighis did not come from homes where women performed pardah or, if they did, it was not as rigorously followed as one might expect. Tablighis, I knew, were always trying to give the best account of themselves, and the longer one spent with them, the more one realized that other Tablighis remained somewhat skeptical of this account. Like me, they also wanted to know how religious the families of others actually lived behind the curtain. What I found was that while the presence of kin had obvious practical advantages, this presence also was seen as evidence for the spiritual quality of the home. In other words, the willingness of multiple Tablighis from a single family to devote labor to the Tablighi Jamaat was the sign of a spiritual home. The creation of a spiritual home was the condition for ascending a spiritual hierarchy. 


\section{CONCLUSION: KINSHIP AND THE SOCIAL CONSTITUTION OF FAITH}

When Umar described to me how faith is fickle, sometimes powerful and sometimes weak, and fleeting, he was directing my attention to the very erratic involvement of people in the Tablighis Jamaat. Some Tablighis were intensely committed to dawat for a period ranging from a few days to a year, and then would gradually slip away, never to return. Others drifted in and out of the movement, but never seemed able to commit fully to dawat. Still others, like Umar, remained within the fold of the Tablighi Jamaat for long periods of time, but they were profoundly troubled by what they saw as the fleeting nature of their own faith. It is hard to generalize about all the particular circumstances that might factor into this erratic participation, but everyone agreed that firm and continuous commitment — understood as certain faith-largely depended on the support or, better still, active participation of one's kin. One finds, then, a range of Tablighis from those who are alone in the movement, like Umar, to those who have patchy and loose kin networks but some support from their kin, like Talha, to those, like Irfan, who are what are often referred to as "familial" Tablighis (khandaani), who have been Tablighis for multiple generations have entirely grown up on the world of the Tablighi Jamaat. Almost everyone recognized that the ultimate goal was to create a proper Islamic family because this was the condition for certain faith.

In the last chapter, I argued that a pious subject is a person who is capable of being a channel for the words of pious others and a faithful transmitter of Islam. This required, I argued, the ability to be a pious listener in relation to those who were deemed more pious than oneself in a religious hierarchy. I wanted to show that one could cultivate pious virtue by living in relationships with other pious people, that is, in a 
community of pious others. In this chapter, what I have shown that "faith" is dependent on factors that exist beyond the ritual space of the mosque. While the ritual ideology of Tablighis suggests that anyone can ascend a religious hierarchy by committing themselves to dawat, the very idea that faith is cultivated by living in a space of pious others means that simply doing dawat is not enough. What I am calling certain faith depends on living with pious others in the space of the home as well. This suggests certain limitations in how anthropologists studying Islamic piety movements have treated the issue of the relationship between ritual and efficacy. Islamic pietists, including Tablighis, say that by doing Islamic practice one cultivates Islamic virtues, but this cannot be taken at face value. Simply because Islamic pietists say that Islamic practice creates inner dispositions does not mean that they actually do. In other words, ritual efficacy does not follow from ritual in the manner that the most official position on ritual ideology would suggest since the efficacy of dawat depends on intimate others, especially kin.

The contrast between Umar and Irfan draws this out clearly. Both Umar and Irfan were active Tablighis and both, to my knowledge, seemed to be fulfilling the explicitly stated "felicity conditions" of dawat as an Islamic practice. Dawat, as I have argued is meant to "grow" faith and create certainty. Yet, only one of them found himself secure in his faith, while the other, found himself profoundly uncertain about the status of his faith. Tablighis recognize that in order to actually create those virtuous dispositions one must continuously live in a social space in which those ethical qualities are valued. But, to live perpetually in Islamic social space requires both disconnecting from those who are not virtuous, like Talha did, or to transform those around you. But, this requires eliciting the 
commitment of those who one does not entirely control. As I have argued, it is when a disjuncture exists between home and mosque that faith becomes precarious, and it becomes necessary to eliminate the disjuncture by transforming the home into an Islamic one. Those who are able to create contiguity between the home and the mosque are understood to be on the path of "certain" faith, while those who do not struggle to stay in the fold of the Tablighi Jamaat. The broader implications of this example is that Islamic piety movements like the Tablighi Jamaat are interested in transforming all public space into Islamic ones, because it is only by doing so that one can ensure that Muslims will come to embody certain faith.

The anthropology of Islamic piety movements has crystallized around trope of ethical self-cultivation in which Islamic practice inculcates ethical dispositions that in turn create the grounds for ethical action (Mahmood 2005; Hirshkind 2006). This approach runs the risk of suggesting that Islamic practice is about an individual acting on himself or herself, a proposition that lends itself too readily to Western common sense ideas of a self-contained and bounded individual. As I have suggested in previous chapters, one comes to Islamic virtues through ethical relationship with others, not by acting on oneself but by being acted upon by others. Tablighis recognize that faith is socially constituted and Islamic virtues are acquired through Islamic relationships. Recognizing that faith is a social rather than an individual achievement also enables us to see the political implications of Islamic piety, which requires for its realization the transformation of all social relationships in the image of Islamic ideals.

In the next chapter, I turn to the political significance of the Tablighi Jamaat in the context of the Pakistani nation. The power of dawat to affect spiritual transformation has 
significant bearing in a nation that already conceives itself in largely Islamic terms. While I have focused in this chapter on certain limitations of the realization of Islamic piety, in the next chapter, I focus on its great promise that the Tablighi Jamaat provides to those who would like to radically alter their place in the world. 


\section{CHAPTER 6 \\ DAWAT AND TRANSCENCE IN AN ISLAMIC NATION.}

This chapter explores the political significance of dawat in the context of the Pakistani nation. While Tablighis claim that dawat has nothing to do with "politics," a position that some scholars have even accepted, my position is that dawat's political significance must be understood through the fact that it has the capacity to radically alter a persons's standing in a nation conceived as Islamic. By allowing one to reshape one's lower self, dawat creates the possibility of "closeness" to Allah. The political significance of this must be understood against the cultural backdrop of the Pakistani nation, which is hierarchically structured in terms of the relative proximity of people to Allah. In Pakistan, hierarchy is informed by differences in genealogy, which divides the population between old and new, high and low, pure and impure Muslims. Dawat creates a temporal link between a Tablighi and the original generative moment of Islam and therefore allows those who are new and impure Muslims to transcend their low social origins. Dawat therefore creates the possibility of ascending a socio-religious hierarchy. It is this possibility, I argue, that has made the Tablighi Jamaat one of the most popular Islamic movements in Pakistan.

Understanding the significance of dawat in the Pakistani context requires that we first underscore the cosmological basis of the Pakistani nation. This necessitates a brief foray into cultural approaches to nationalism and, in particular into how anthropologists have dealt with the question of religion. The most prominent cultural theorists of nationalism have understood nationalism as a modern ideology inextricably bound to a liberal ontology in which a person is conceived as an autonomous, bounded individual. In his study of Quebecois nationalism, Richard Handler (1988) argues that nationalism is a 
"modern" ideology predicated on ideas about the nature of persons, and things, as distinct, bounded and individuated units. According to Handler, in such an ideology, individuals are assumed to share a cultural essence that constitutes national identity. Whatever differences may exist between subjects of nation, they are presumed to share some essence. Hence, nationalism, Handler argues, is an ideology of "homogeneity encompassing diversity.” Following Dumont (1986), Handler argues nations are conceived as both a collection of individuals, each with their own "self," as well as a collective individual, constituted by a singular "self" or "culture" that bounds it off as distinct from other nations. Nationalism presupposes the existence of an "essence" and politics proceeds as a struggle over what qualifies as the "essence" of national being, or what Handler calls "the politics of culture."

While Handler does not explicitly develop a theory of religion except as nationalists construct it as the "essence" of national culture, a theory of religion is central to Benedict Anderson's (1991) now classic work on nationalism, Imagined Communities. Anderson argues that nationalism, rather than being an ideology like Marxism or Liberalism, is itself "species of religion." By this, Anderson means that nationalism is not one or another political orientation, but a cosmological order with its own distinct style of imagining person, time, and space. Anderson draws a sharp contrast between the national community and the "religious community," arguing that the latter is hierarchical, with the apex being divine, while the former is egalitarian and conceived in terms of horizontal comradeship. The religious community, according to Anderson, is characterized by "alchemic absorption" by which Anderson means that at least in theory it can potentially encompass all of humanity, while the nation is conceived as "limited" and boundary- 
oriented: "The nation is imagined as limited because even the largest of them encompassing perhaps a billion living human beings, has finite, if elastic boundaries, beyond which lie other nations" (1991: 6). According to Anderson, while the religious community locates sovereignty in the divine, nations locate sovereignty in the people. In other words, for Anderson the nation is both "egalitarian" and "secular."

Talal Asad's (2003) influential theorization of secularism also weighs in on the theoretical debate on nationalism. Asad argues that the very opposition between "religion" and "the secular" recreates the telos in which non-liberal traditions are understood to be remnants of the past rather than creative reformulations of tradition in the face of new circumstances. Asad argues that distinctions like religion/secular and private/public are internal to secularism. Secularism, he notes, should not be thought of simply as the privatization of religion, understood as the liberation of the public sphere from religion. Rather, secularism entails a deeper historical grammar that includes concepts like "nature" and "the social," which imagined to be more objective and real that "religion." Religion, in this formulation, is epiphenomenal and a symbolic representation of an already given objective reality. Asad's argument is largely in keeping with anthropological thinking about distinctions like nature/culture and individual/society in which the former is understood as real and objective while the latter is seen as artifice (Strathern 1988). According to Asad, nationalism is built on the historical grammar of secular modernity that divides the world between religion and politics, private and public, and individual and the social. Even as Asad disavows a universal theory of religion, he like the other theorists mentioned above nevertheless anchors nationalism in the ontology of individualism. 
In contrast to this perspective, scholars of nationalism in South Asia have challenged the "great divide" theory of nationalism (van der Veer 1994) in which religion falls on the side of tradition and nationalism on the side of modernity (Chatterjee 1993; Kapferer 1989; Van der Veer 1994). Drawing on the powerful critique of liberal historiography initiated by Ranajit Guha (1982), Partha Chatterjee (1993), argues that nationalism in India was shaped by the colonial circumstances in which it arose. To Anderson's universal theory of nationalism, Chatterjee asks provocatively: "if nationalisms in the rest of the world have to choose their imagined community from certain 'modular' forms made available to them by Europe and the Americas, what do they have left to imagine?" (1993). Chatterjee goes on to argue that anti-colonial nationalism was both based on Western models but at the same time built on a difference from those models. This question raises the possibility that nationalism can take many forms according to cultural and historical context. However, Chatterjee argues that anticolonial nationalism adopts the essential division between East and West coded as "spiritual" and "material," a distinction that props colonial authority by associating the West with "modernity" and "progress" and the East with "backwardness" and "stagnation," but inverts this structure of colonial domination. In other words, for anticolonial nationalists in India, the West becomes corrupt and materialistic, while the East is constructed as morally and spiritually robust.

Chatterjee's argument is not without its merits. Indeed, the writings of nationalist leaders like Gandhi and Jinnah as well as a host of prominent South Asian writers and poets provide good evidence for this perspective. Nevertheless, as he notes explicitly, Hindu nationalism is not "the vestige of some pre-modern religious conception. It is an 
entirely modern, rationalist, and historicist idea" (1993: 110). For Chatterjee, and many postcolonial theorists (see Pandey 1999), non-Western forms of nationalism are different from Western forms only in terms of what qualifies as the "content" of national character (spirituality as opposed to materialism). This argument does little to advance what theorists of nationalism have already established: nationalism is an ideology that presupposes the existence of an essential similitude. There is, then, very little that is actually "religious" in any substantial sense in Chatterjee's anti-colonial nationalism. Such a perspective evades the questions of religious ontology and, by extension, also evades whether the nation can in fact take multiple forms.

Other scholars, however, have argued that cultural alterity must be brought into the theory of nationalism itself (Kapferer 1989; van der Veer 1994). Kapferer argues that despite their differences, prominent scholars of nationalism like Anderson (1991) and Dumont (1986) define nationalism as an "egalitarian" ideology displaces or externalizes hierarchy beyond the boundaries of the nation, creating an internal egalitarianism in which each individual member represents the collective. Kapferer notes that both have an evolutionist approach to nationalism in which the modern, egalitarian ideology supersedes a traditional hierarchical one. Kapferer argues that while nationalism in Australia is anchored in the ontology of egalitarian individualism, Buddhism frames Sri Lankan nationalism hierarchically in the Dumontian sense that ultimate value is placed on the whole rather than the part. This substantially shapes the kinds of moral concerns and dilemmas that are raised in Sri Lankan nationalism as well as the forms of violence that emanate from it. 
Similarly, Peter Van der Veer (1994) argues that nations are constructed from both old and new symbolic resources. For Van der Veer, nationalism in fact is shaped by older religious traditions in India. Van der Veer shows that two sites in which this religiosity is apparent is in ritual communication and in conceptions of time. He argues that Indian nationalism must, then, be understood as a "religious nationalism." I find the relativizing impulse in the concept of religious nationalism to be appealing, however, given that the religion/secular division is, as Asad has demonstrated, itself a feature of secularism, I am wary of using such term. The concept of religious nationalism runs the risk of reproducing the religion/secular binary in which religious nationalism would become the "other" of secular nationalism. As I will show below, this is precisely the thinking that has shaped most of the historiography of Pakistan which treats the religious forms of nationalism as fundemantally flawed and prone to fragmentation, and insists that it is only secularism that can save the Pakistani nation. Here, I want to point out that if liberal-secular nationalism is one variety of nationalism, then one can imagine not a single religious nationalism as its alternative, but a variety of nationalisms shaped by culturally distinct ontologies.

In this chapter, I show that the Islamic tradition furnishes an ontology that divides the subject between "spirit" and "lower self," a distinction that also maps onto distinctions of inner/outer, pure/impure, high/low, and right/left. This conception of the person lays the ground for a nation that is hierarchically structured according to a person's relative proximity to Allah. Moreover, it divides the world practices into domains of "religion" (din) and "the world" (dunya), sacred and profane, and transcendence and immanence in which the latter supersedes the former. Let us turn now 
to how the historiography of Pakistan, which is largely informed by liberal-secular assumptions about religion and treats religion as epiphenomenal. I argue that this approach to religion both fails to account for some of the most significant events in Pakistani history, like the Pakistani civil war that led the violent rebirth of East Pakistan as Bangladesh, and obscures the logic underpinning pietist movements like the Tablighi Jamaat.

\section{AN ISLAMIC NATION?: RETHINKING SECULAR HISTORIOGRAPHY}

The demand for Pakistan as an independent state for India's minority Muslim population was predicated on the two-nation theory that posited that Hindus and Muslims were two essentially different communities and that Muslim could not live freely as a minority in Hindu India. Muhammad Ali Jinnah, chairman of the All India Muslim League and "father" of the Pakistani nation, gave a speech at the All India Muslim League Conference in 1940 that reflects the leaderships' understanding of Muslims and Hindus as two mutually exclusive totalities: "The Hindus and Muslims belong to two different religious philosophies, social customs, literatures. They neither intermarry, nor dine together, and they belong to two different civilizations which are based mainly on conflicting ideas and conceptions." This statement fits with Handler's (1988) definition of nationalism as an ideology premised on the notion of an essential similitude. The twonation theory formed the foundational premise for the Muslim League's demand for an independent Pakistan. This theory stated that whatever linguistic and cultural differences may have existed among Muslims, Muslims shared an essential national identity that 
distinguished them from Hindus. Jinnah and the rest of the leadership had an essentialist understanding of religion as the basis of Pan-Indian Muslim culture.

Historians of Pakistan generally agree that while the demand for Pakistan was predicated on a Muslim identity, the leadership of the All India Muslim League, the main organ of the Muslim nationalism movement, did not envision a state governed on the basis of Islamic law (shariat) or imagine much of a role for Islamic clerics ('ulema) in the functioning of the state. The famous address made to the Pakistan Constituent Assembly by Muhammad Ali Jinnah, the "father" of Pakistan, on August 11, 1947 in which he advocated for equal citizenship for all inhabitants of the territory of Pakistan regardless of caste, creed or religion seems to confirm this argument. Furthermore, the fact that the collective body of Islamic 'ulema of India the Jamaat-e-ulema-e-Hind opposed the formation of Pakistan because it would leave India's Muslims divided has also been marshalled as support for the claim that the Muslim League represented a "secular" position on the Muslim nation.

Today more than ever, Pakistani secularists invoke Jinnah's battle with the 'ulema in order to make the case that the Pakistani nation-state was built on "secular," not Islamic, foundations. This argument is not without its merits. There is sufficient evidence that the Muslim League leadership aspired to create a state on a secular model that separated "religion" and "politics" and relegated religion to the "private" sphere. In an oft-cited speech to the Constituent Assembly on August 11, 1947, proclaimed:

You are free; you are free to go to your temples, you are free to go to your mosques or to any other place or worship in this State of Pakistan. You may belong to any religion or caste or creed -- that has nothing to do with the business of the State.... Now I think we should keep that in front of us as our ideal, and you will find that in course of time Hindus would cease to be Hindus, and 
Muslims would cease to be Muslims, not in the religious sense, because that is the personal faith of each individual, but in the political sense as citizens of the State.

This statement on the eve of independence is indicative of the liberal-secularist sensibilities of the Muslim League leadership. Not only is Jinnah advocating a separation of religion and state, he also regards religion as a matter of private belief of an individual. One finds here a conception of religion that is far from the theological practices of the 'ulema. While accepting the claim that many of the leaders of the Muslim League had a definitively "secular" conception of the world, at least in that they saw more or less as an essence of national identity, I to use this section to show how these very same secular assumptions are reproduced in historiography of Pakistan in a way that obscures how many beyond the Muslim League leadership conceived of the nation in Islamic terms, and how the notion of an Islamic nation shaped crucial events in Pakistani history, like the Pakistani civil war (Bangladeshi war of independence) of 1971.

Historians of Pakistan have often organized their narrative around the political bargaining between the major representative bodies in India, the All India Muslim League, the Indian National Congress, and the British. In this work, the Partition figures as an administrative event, the product of elite bargaining that is largely detached form the micro-politics of ordinary Muslims. This, and the fact that many of the leading 'ulema of India opposed partition and even called Jinnah the "Great Infidel" (Kaafir-i-Azam), has made it easier for scholars as well as secular nationalists in Pakistan to accept the thesis that the movement for a Muslim nation was a "secular" rather than a substantively “Islamic" project (Jalal 1985). Paradoxically, historians of Pakistan also treat Pakistan as a nationalism, which in Salman Rushdie's famous phrase is "insufficiently imagined." 
These historians have argued that because of its diverse ethnic and linguistic heritage, Pakistan has little or no basis for national unity (Jaffrelot 2002; Shaikh 2009). From this perspective, Islam has served as a poor or "insufficient" way to imagine a nation (see Dhulipala 2011 for discussion). From this perspective, Islam emerges to fill a void that would otherwise be filled by linguistic and cultural similitude. The presumption here is that Pakistan, unlike other nation-states that are presumably built on "objective" criteria, is distinctly artificial. Even scholars who recognize that all nations are constructed or "imagined," nevertheless make this claim. Ayesha Jalal, for instance, writes: "Pakistan with its artificially demarcated frontiers and desperate quest for an officially sanctioned Islamic identity lends itself remarkably well to an examination of the nexus between power and bigotry in the creative imaginings of national identity" (Jalal 1995). In other words, religion is not an objective criteria for national unity and the efforts to impose it on others is rooted in bigotry and violence.

Both the claim that Pakistan was originally conceived as a "secular" nation and only later corrupted by the political machinations of Islamists and the claim that Pakistan was conceived as "religious," which is what explains its fragmentation reinforce the secularist perspective that nations, or at least successful nations, must be secular. This is partly because religion itself is seen as subjective rather than objective, unlike languge and culture. In the first narrative, the secular was the original grounds upon which Pakistan was conceived but was progressively lost over the years. A return to this secular ground would redeem Pakistan. In the second narrative, Pakistan was actually conceived in religious terms, which makes it inherently prone to conflict and fragmentation. In this second position, there is little left to redeem except to reject the original conception of 
Pakistan for a more secular vision. Both of these narratives resonate with Pakistani liberals, some of which say Pakistan can be redeemed through a return to the original vision of Jinnah, while others blame Jinnah for playing on religious or "communal" differences, implying that the narrative of Pakistani nationalism is irredeemably flawed. Both of these narratives actually affirm Anderson's thesis that the nation must become "secular" (the project of secularism) in order to be a proper nation.

David Gilmartin's $(1988,1998)$ work presents a very insightful counterpoint to this liberal-secular historiography. Gilmartin's examination of the 1946 elections in rural Punjab in which the Muslim League defeated the anti-Pakistan Unionist Party, demonstrates that for rural voters in the Punjab, Islam was the ground for their support for the Muslim League's demand for Pakistan. Gilmartin argues that while those who favored the Muslim League and by extension the creation of an independent Muslim nation were deeply concerned about Hindu domination in a post-Independence India, their primary reasons for supporting the Muslim Leage was actually because of their fear of internal conflcits among Muslims. Gilmartin shows that much of the Muslim League's election materials all aimed to show how Islam could serve as a transcendental basis for unity in a context deep intra-Muslim rivalries. "The moral necessity of Pakistan," Gilmartin writes, "was rooted rhetorically in opposition to a very different Other-the specter of internal dissension and disorder among Muslims themselves” (1998: 422). Gilmartin demonstrates that nothing preoccupied the minds of rural Punjabi Muslims more than the fear that the withdrawal of the British would lead to an all out conflict among Muslims and lead to a state of moral chaos (fitna). 
While internal unity and integrity is arguably always a concern for nationalists, here the threat felt by those that supported the Muslim League and committed to Islamic unity was much more specific. One flyer, for example, shows Jinnah imploring fellow Muslims to support Pakistan "for the sake of Islamic morality (akhlaq), Islamic unity (ittehad), and Islamic teachings (ta'limat)." The same poster stated, "we can bear difference of opinions, but we cannot bear disturbance, riot, curses and lies." (Gilmartin 1998: 423). Another poster claimed that the "purpose of Ahrar," a rival party with little influence, "is only to cause an uproar (hangama), even though today the first duty (farz) of India's ten crore (100 million) Muslims is to become one" (1998: 423). The most fierce attacks were made on the Unionist party, which the League insisted was playing on "tribal feeling" (qabaili asabiyat) and encouraging "moral disorder of the age of ignorance" (fitna-i-jahaliyat), which is the disorder that reigned over the Arabs before the advent of Islam. As Gilmartin argues, the danger of moral chaos (fitna) rested in the fact that it was not simply a product of the machinations of political parties like Ahrar or Unionists, or even the British, but that it was an ever present feature of Punjabi Muslim rural life, part of the push and pull of powerful patrilineal kinship groups or "brotherhoods" (biraderis).

The Muslim League constructed Pakistan as an "independent Islamic state" (azaad Islami-riyasat) that would defend Muslims against the threat of moral chaos and divisiveness, which would surface when the British left India. "The enemies of the Muslims are two," proclaimed one flyer, "Color and genealogy (rang o nasab), that is, the fitna of tribes and biraderis, and country and homeland (mulk o watan) that is the idol (but) of quamiyat and wataniat." This statement summarizes the opposition between 
Islam/Pakistan and the more parochial loyalties of genealogy and land. Gilmartin has correctly noted that distinctions among Muslims along genealogical lines was actually presupposed as a fundamental feature of Muslim sociality, and it was the task Islam to transcend the destructive potential of these forces. This was not tantamount to the denial of the existence of difference and a claim of essential similitude. On the contrary, it is a form of nationalism that seeks to channel these energies towards a greater goal:

"Muslims! Break the idols of rang o nasab and quam o watan. The honor (izzat) of your biraderi and tribe, the honor of your family—all are from the honor of Islam and the Muslims. With this purpose the Muslim League has risen up; for this reason, the Pakistan demand is being made" (Gilmartin 1998: 425).

Islam was the grounds for transcending "worldly" ties and interests and creating a greater spiritual unity. I will return to how Islam did this, for it remains unspecified in Gilmartin's account, but is important for thinking through an Islamic nation. The point here is that for the rural Punjabi Muslims that Gilmartin is referring to, the call for "unity" was imagined as a religious duty to offset the possibility of moral disorder and divisiveness, a condition that makes it impossible to live out a religiously inspired life. It was a call, ultimately, not for the erasure of all difference and the recognition of essential similitude, but for an ethical project of learning to live together peacefully despite those differences. The language of unity was invoked by the leaders of the Muslims League, some of whom espoused avowedly secular ideas in other contexts, as well as spiritual leaders (pirs) and landed nobility whose authority rested on the privileges of their genealogy. As Gilmartin sensitive reading of the historical record shows, even as the Muslim League leadership made essentialist cultural arguments, the political struggle for 
an independent Pakistan was fought by invoking the capacity of Islam to unite Muslims. The Muslim League had come to embody the transcendental principles of Islam that stood above and beyond "worldly" interests. The Muslim League had come to imagine itself as above the conflict of the world, and as an embodiment of the transcendental principles of Islam.

In an ethnographic exploration of the political culture of Pakistan's Muhajirs, Muslims who migrated from what is now India to Pakistan during Partition, Oscar Verkaaik (2004) argues that migration was conceived in terms of the Prophet's "migration" (hijrat) from Mecca to Medina. In Islamic history, the Prophet and his companions escaped the persecutions of the powerful tribes of Mecca to be received by the ansar or "helpers" in Medina, and it was in Medina that a true Islamic community was born. The term muhajir derives from the root hijr, and the movement from India to Pakistan represented a movement from "the abode of war" (dar-ul-harb) to "the abode of Islam" (dar-ul-Islam), which was also conceived as a movement from "ignorance" (jahiliyat) to "knowledge" ('ilm). The creation of Pakistan was imagined, as with the hijrat as the birth, or re-birth, of Islam itself.

The idea that the nation was itself Islamic and that supporting it was an Islamic duty furnished much of the support for Pakistan. The commitment to Pakistan was seen as attesting to the truth of Islam and specifically the truth that Islam had the capacity to address both the internal problems of Muslims divided along kinship and caste, as well as provide a space where Muslims could be free of the domination of Hindus, a domination that threatened both material and spiritual well-being. One remarkable achievement of Muslim nationalism was to link these internal and external threats, both the danger of 
moral chaos caused by commitment to "color and genealogy" (rango-o-nasb) and the danger of living under a Hindu majority to a single problem, the failure to live up to Islamic ideals. It provided a single solution, namely Islam. The spirit of Islam would help Muslims transcend their own "lower self," which was the source of internal divisiveness, while also standing against the threat to Islam posed by Hindus. Pakistan and Islam as "spirit" (ruh) and "religion" (din) would stand in contrast to the "lower self" (nafs) and "the world" (dunya) of Hinduism and India (cf. Gilmartin 1988).

Muslim nationalism provided a framework that located the Hindu other as the source of internal Muslim problems because it was Hinduism that was having a corrupting influence on Islam. The creation of Pakistan, in this sense, was about creating the space in which Muslims could live as Muslims, free of the distorting and corrupting influences of Hinduism. Pakistan would be where "pure" Islam would thrive, a fact captured in the very name of the country, which means the "land of the pure." In the postIndependence period, the state emerged as a key actor in the reform of Islam (Verkaaik 2004). The legitimacy of the Pakistani state from its inception was linked to its ability provide the space for an Islamic life. The Objectives Resolution to the Constitution of Pakistan passed by the Constituent Assembly on March 7, 1949, less than two years after independence, states: "Sovereignty belongs to Allah alone but He has delegated it to the state of Pakistan through its people for being exercised within the limits prescribed by Him as a sacred trust." Here one can see that although Pakistan's people were sovereign, their sovereignty was to be exercised within the limits of Islam. It was the task of the Pakistani state to ensure that laws were passed within the bounds set by Islam. Under the dictatorship of General Zia-ul-Haq in 1970s and 1980s, this tendency grew into campaign 
to establish the Order of the Prophet (nizam-e-Mustafa), an Islamization campaign aimed at creating an Islamic state governed in large part by Islamic law. While many secularliberals in Pakistan see in this period the demise of the secular state, the campaign was actually built on an idea of Islamic sovereignty that was at least a significant feature of the popular imaginary of Muslim nationalism.

I discussed how the distinction between religion (din) and custom (rivaaj) thoroughly in Chapter 2 in which Islamic reformers of Deoband insisted on the purification of Islam of Hindu corruptions. In this framework of Islamic reform, one can see how Islam is "divine" while "custom" is "worldly." At the level of the person, this maps onto the spirit and the lower self. What I am arguing here is that even though the secular-nationalists did not align themselves with the politics of the "ulema, Muslim nationalism nevertheless drew on the framework of Islamic reform in which Islam purified of custom was the basis of a greater Islamic unity. This resonated with those who conceived of the greatest threat to Muslims to be the commitment of "colour and genealogy" (rang-o-nasb) that is to forms of kinship and affiliation based on genealogy. The greatest threat was imagined to be inter-clan rivalries that could lead to the total breakdown of order. Indeed, even today the commitment to an Islamic unity is strongest among Pakistani Punjabis where the force of genealogy as an organizing principle of life remains strongest. It is the threat of disorder that inheres in genealogical affiliation that Islam is meant to counteract.

If Islam was the basis of a transcendental unity, then this also meant that some were more proximate to the pure form of Islam. This is especially evident in the unfolding of the conflicting relationship between West Pakistan and East Pakistan that 
ended in the cataclysmic civil war of 1971 and culminated in the violent rebirth of East Pakistan as Bangladesh. In both liberal and Marxist historiography, the West Pakistani elite, especially Punjabis and Muhajirs who dominated the military and civil bureaucracy, were hostile towards Bengalis and treated them contemptuously as unIslamic or Hinduized. Since the early 1950s, the Bengali language movement had been demanding equal recognition for Bangla as a national language at par with Urdu, but West Pakistani elites regarded it as too "hinduized" to be given the status of a national language, unlike Urdu which was coded as an Islamic language (Toor 2011; see also Ayres 2009). As David Lelyveld has argued, the association between Urdu and Islam can be traced back to argument in the late $19^{\text {th }}$ century that posited Urdu as being close to "the spirit" (ruh) and thus the language most suitable for India's Muslims (Lelyveld 1993). The inferior status of Bangla was confirmed in the minds of West Pakistanis because of its use of a Sanskritbased script rather than the nastaliq script of Urdu, which is derived from Persian and Arabic.

The effort to contain the Bengali majority is most evident in the enactment of the One Unit policy by ruler Preseident Ayub Khan in 1954. Khan amalgamated the provinces of West Pakistan into one administrative unit and created a system in which both East and West wings had a parity of representation with equal seats in a single chamber national legislature. This was part of larger strategy to ensure that East Pakistan would not acquire a decisive say in the running of the country. In his autobiography, Ayub Khan justified this position by saying that Bengalis "belong to the very original Indian races," "have been and still are under considerable Hindu cultural and linguistic influence," and "have not yet found it possible to adjust psychologically to the 
requirements of the new born freedom." (cited in Verkaaik 2004: 29). Ayub Khan's use of the English term "race" here evidences his station in the English speaking upper classes trained in the British tradition, but the fact that race is affected by "cultural and linguistic influence" suggests that, unlike in theories of biological racism, race here does not mean an immutable biological essence. Moreover, Khan's use of the term "original" also suggests a temporal dimension to this category that is not in keeping with standard Western understandings of race. What Ayub Khan is referring to here is zat, a term that can roughly translate to caste and is derived from one's genealogical origins. The term also translates as "self" in Urdu. Indeed, what Ayub Khan was actually implying when hecalled Bengalis "the original Indian races," was that their origins were Hindu and they had only recently converted to Islam, a fact that meant that they had not come to fully embody pure Islamic values. The final pont that they "have not found it possible to adjust to ... freedom" implies that they remain disorderly, and in need of social and political oversight.

In both liberal and Marxist historiography, the contemptuous treatment of Bengalis by West Pakistanis is framed as "ethnic chauvinism" or "racism." Saadia Toor (2011), for instance, rightly notes that the subjugation of the East by the West was premised on the notion that Bengalis were ajlaf or populations whose origins were "local" and thereby considered Hindu, while the West Pakistani elite regarded themselves as being ashraf because their origins could be traced to the Middle East and Central Asia, a distinction that I argued in chapter 2, was central to the organization of noble and commoner populations in the Mughal period. It is telling, then, that a significant portion of the Bengali ashraf remained committed to the idea of Islamic unity in Pakistan and 
supported West Pakistan against the Bengali liberation movement. While noting this, Toor proceeds to define the distinction between ajlaf and ashraf as "a racialized discourse of difference" (2011: 27). She attributes to the support for West Pakistan among the Bengali ashraf as based on "an ongoing class struggle within East Bengal" between the Bengali aristocracy and the Bangla-speaking middle class. Despite drawing on native concepts, Toor assumes that this is the playing out of "race" and "class" conflict in a native idiom. Toor, then, effectively erases the question of Islam from the constitution of the distinction between ashraf and ajlaf for what are imagined to be the more "objective" grounds of class. Once again, religion as a substantive cosmological framework treated as epiphenomenal.

In the next section, I draw on my own ethnographic experience to show how Islam is infact constitutive of the national imagination in Pakistan and that categories like "ethnicity" and "nation" must be thought of in light of Islamic distinctions. The failure to do so elides a great deal of politics of nationhood in postcolonial Pakistan.

\section{ISLAMIC HABITUS, GENEOLOGY AND THE POLITICS OF NATIONHOOD}

Raheem and I were both new companions on our trip to the national congregation or ijtima in Raiwind in 2010. Raheem was a stocky Pathan of Afghani origins who had been raised in Karachi. He spoke in a soft and comforting voice, and had a very gentle demeanor. During our travels, Raheem went to great pains to make sure that he was upholding his duties to care for others. He was especially concerned about my comfort, because he felt that this trip might be harder on me than the others. We had developed a warm friendship. Raheem did not live in the Al-Aqsa neighborhood but owned a real- 
estate agency on the main road adjacent to the area. His shop was next to Shakil and Sultan's shop, who were both regulars in the Al-Aqsa congregation. They were good friends and along with other business owners on the strip frequently ate and prayed together. Sultan had convinced Raheem to come on the chilla and Raheem had agreed, but Raheem did not participate fully in the life of the Al-Aqsa congregation. Raheem had a short beard but continued to grow it through his chilla (forty-day tour) and maintained a longer beard well after his dawat tour. Despite his changed appearance, Raheem never became a fully committed Tablighi. He would occasionally come for sermons at the AlAqsa mosque and he would attend the annual congregation in Karachi, but he said that that was sufficient for him. He also cautioned that too much participation in tabligh made one disconnect from the world and led many people to abandon their responsibilities to their family, a common criticism against Tablighis.

I visited Raheem several times at his real-estate agency, though he was generally too busy to talk to me at length. He did not want to be recorded in these conversations because he insisted that he was not qualified to speak about Islam and that he might be spreading "falsehood." The term Raheem used was munafiqat which means hypocrisy, but the root of the word actually also means a "chasm" or "gap," meaning a gap in the truth or the introduction of falsehood in truth. Raheem was very concerned about this, but after my repeated insistence that I would not ask him anything about Islam as such but will focus on his own background and experience, he relented. A few minutes into our conversation, Raheem's friend Mahmood entered the store. Mahmood was a thin man of approximately thirty-five years of age with dark skin, a small face, and sharp angular features. His beardless face betrayed the fact that he was not associated with the Tablighi 
Jamaat or any other Islamic movement or organization. Like Raheem, Mahmood was also a real-estate agent and had an office a few shops down. The exchange that transpired tells us something central about the relationship between Islam, "ethnicity" and "nation" in Pakistan, and therefore, I will reproduce the exchange in detail.

"What is going on here?," Mahmood asked with a grin across his face. "An interview," I said. Raheem was visibly embarrassed and sheepishly introduced us. "Why would you interview him? This Pathan doesn't know what he is talking about!," Raheem laughed and replied, "Arsalan, do not listen to this memon. Memon are always doing ‘ethnicity worship' (quam parasti). A Memon will always to stick to his own kind, no matter what happens. This is bad. They are selfish people.” Mahmood laughed. Raheem continued, “These people don't even have a country. Tell me, Arsalan, when you think of Pathan, do you think of a place, a country where they are from? Yes, you think of Afghanistan! We Pathan were royals, related to the highest emperors!" Mahmood retorted, "Ask him if he even knows who the Mughals were. These Pathan are always fighting among themselves. And they have sold off their own country to the Americans! They are all for sale. Would a Memon ever do such a thing? Never!" "Arsalan," Raheem protested, "These Memon were Hindus till one or two hundred years ago. They are baniya! Their faith is not strong like us Pathan." "So what if we were Hindus? What does that matter? MashAllah, we accepted Islam and read the Kalima. You Pathan are always talking about what your grandfathers and great grandfathers did. What have you done? You don't do anything but fight among yourselves and you have sold off your country!" Raheem laughed and batted his hand at Mahmood as if to dismiss the conversation. A 
grinning Mahmood, then, said he would be back to discuss some matter later and took his leave.

This jocular exchange between two friends highlights the significance of ethnic joking as a means of maintaining social harmony in a city as diverse as Karachi. In this context, ethnic joking transforms negative stereotypes, which are often the grounds for violent ethnic conflict, into a source of camaraderie. But, the joking relationship between Raheem and Mahmood also evidences some deep assumptions within Pakistani nationalism, one that is the grounds for broad based hierarchical differentiation between people on the basis of their origins and history of conversion to Islam. When Mahmood left, I asked Raheem whether it was appropriate to differentiate people on the basis of when they converted to Islam, as he had said in the joking encounter. Raheem explained:

These people are always differentiating themselves on the basis of their 'ethnicity' and language. All Muslims that have read the kalma are brothers. There's a hadith that when the forces of the Prophet were fighting Abu Jahel, they had tied up all the prisoners. And one person said: 'tie that one up tight. He is from a rich, powerful family.' And the man protested: 'but you are my brother!' It was his own blood brother who said it. He had converted to Islam. And the brother responded, 'No! These are my brothers. The ones that fight with me for our Beloved Prophet!" So, you see, all Muslims are brothers, but these people don't understand this. It is because their faith is weak.

But, was this not precisely what Mahmood was trying to say, that there is no difference between Muslims as long as they have accepted Islam? Raheem said that Memons have weak faith, so they are not able to recognize their relationships with other Muslims, and thus they are prone to "ethnicity worship" (quam parasti). The term "worship" here is the same word that is used for the worship of idols, and Raheem was saying that the failure to relate to other Muslims as brothers was tantamount to idol worship. I asked Raheem if 
such a charge against another community was not itself a form ethnicity worship, and he categorically denied it, saying that faith is the basis for distinguishing Muslims, and their faith is weak so they are prone to such slippage. Raheem explained that Muslims with strong faith are able to recognize their relationship with other Muslims on the basis of Islam and are able to see beyond "worldly" criteria like "blood" (khoon) and "language" (zabaan). It was faith that allowed Muslims to transcend worldly ties and create spiritual ones. Faith is the grounds for the transcendental Islamic community.

What is crucial to note is that "faith" here is not a matter of "belief." As Talal Asad reminds us, the conecpt of belief fails to capture the idea of religious practice as a "constituting activity in the world" that is so central to the Islamic tradition (1993: 47). Faith in the Islamci tradition is a material product of practice that grows through repetition. Following Mauss, Asad argues for the usefulness of the concept of habitus for understanding how persons and bodies are constituted through practice. According to Asad, Mauss understood the human body as a "self-developable means by which the subject achieves a range of human objects - from styles of physical movement (for example, walking), through modes of emotional being (for example, composure), to kinds of spiritual experience (or example, mystical states)" (2003: 251 - 252). Asad argues that Islamic tradition also draws on a logic that can be traced back to Aristotle in which ethical sensibilities are cultivated through practice.

This is precisely the logic that Raheem is drawing upon in the quotation above. Raheem distinguishes Pathan from Memon according to how faith, as a material property, has accumulated and seeped into the bodies of people over time. In Raheem's quotation, faith derives from the longevity of one's Islamic past, which creates the ethical 
sensibilities to transcend parochial and "worldly" attachments, which in turn allows one to devote oneself to a transcendental cause. Included in these ethical sensibilities is the ability to transcend one's own "worldly" ties of kinship and language and recognize oneself as part of the broader Islamic nation and global Islamic community. Those without a deep Islamic past lack the requisite faith to live an Islamic life. In the above conversation, the ethical sensibilities of Islam are not simply in the bodies of individuals either. Rather, Islamic habitus is diffused across "ethnic" communities. Islamic sensibilities are distributed unevenly in terms of the spread of Islam and the history of conversion. In Raheem's quotation, the deeper is one's Islamic past, the more robust one's faith, and the more capable one is of participating in and realizing the virtues of a transcendental Islamic community.

It is not difficult to see how the distinction between ashraf and ajlaf that I pointed to in the last section is homologous to the distinction between the spirit and lower self at the level of the person. From the perspective, the ashraf have the Islamic sensibilities that are the product of an Islamic habitus that has been transmitted genealogically. This is equivalent to saying that they their lower self has been reformulated in terms of the spirit. I had the opportunity to discuss this point at length with Talha, who traces his own genealogy to the Prophet's family. According to Talha, those who do not have a deep Islamic past are much more likely to practice Hindu "customs" (rivaaj), especially in their homes, while those who have a deep Islamic past have "customs" already shaped by Islam. For the former, living an Islamic life is always difficult, and such people are prone to "slipping." For the latter, however, Islam comes effortlessly and even unconsciously. This did not mean that they do all their practices (amal), but it does mean that their 
everyday lives are so infused with Islam that they are often living in Islamic ways to which even they themselves are unaware. For those without a deep Islamic past, Islam requires constant effort while for those with an Islamic past, their customs are already Islamic. One can see here how this logic about temporal depth is actually directly parallel to the point I made in the last chapter in which those with an Islamic family already have Islamic sensibilities and thus find it easy to live an Islamic life. I will retun to this point in the next section.

There is something implicit in the conversation between Raheem and Mahmood that could not be spoken about openly among friends because it would put too great a strain on the relationship. This is the unspoken implication that those with deeper Islamic genealogies are also the ones responsible for bringing Islam to the region and bestowing Islam on to others. This recalls another aspect of Mauss's work to which the anthropology of Islam has been less attentive- the concept of the gift (Mauss 1969; see, however, Anderson 2011). Mauss stresses that gifts are not freely given but actually part of a system of mutual obligation between people, that gifts carry the spirit of the giver, and that they bind people into moral relationships. But, Mauss also stresses that the initial gift, the one that establishes the relationship, can be given freely and this gift can never be fully reciprocated (see Carrier 1991: 123). It is for this reason that the gift produces enduring hierarchical relations. The gift of Islam creates a hierarchical distinction between those who brought Islam to the region and those who are recipients of the gift of Islam, a gift that ultimately places those below in a perpetual state of debt that can never be reciprocated. The notion of an Islamic habitus implies the continuation of a hierarchical relationship between givers and receivers of Islamic knowledge and virtue. It 
is this hierarchical distinction that the West Pakistani establishment invoked in their effort to contain the Bengali movement in East Pakistan, which, by virtue of having risen up against West Pakistan were believe to be rejecting the "magnificent gift" of Islam (cf. Gilmartin 1998).

Hierarchy is central not only to the relationships between ethnic communities, which is the stress in the conversation between Raheem and Mahmood, but is actually entailed within them as differences between castes (zat) who nevertheless share a linguistic and regional identity (Sindhi, Punjabi, Pathan etc). What I am describing here is similar to Engseng Ho's (2006) point about Hadhrami Syeds, Yemeni descendants of the Prophet, who migrated out from Yemen from the $16^{\text {th }}$ century onwards and settled around the rim of the Indian Ocean. Ho notes that these Syeds came to speak many languages and ultimately came to be part of many different ethnic and national communities, speaking local languages, but they maintained their genealogical distinction through asymmetrical marriage practices in which male Syeds married "local" non-Syed women, but Syed women did not marry non-Syed men. Because of a theory of procreation in Syed spirituality and identity pass through male lines, Syeds multiplied their lineages while maintaining genealogical distinction. The point to draw from this is simply that "ethnic" and "national" community, even as it is constructed around shared language and culture, need not erase genealogical distinctions deemed valuable and important. In Pakistan, even as people identify with ethno-regional communities and languages (Sindhi, Balochi, Punjabi, Pathan, Muhajir), these are not conceived as egalitarian units based on some essential similitude. Rather, they remain structured by the same kinds of 
genealogical distinctions that I have been describing, which broadly conceived distinguish Islamic or ashraf from non-Islamic or ajlaf origins.

Segal and Handler (2006) have argued that nationalism is built on the principal of similitude, the presumption that each member of a nation shares an "essence." To use David Schneider's (1968) distinctions, this "essence" can be constructed in both natural and biological terms, as a property of substance (like blood), or in cultural and ideational terms as a property of "code." The term "ethnicity" in Western thought, Segal and Handler note, is a middle-term, nestled between race understood to be based on shared biology and nation understood to be based on shared culture. As a native Western concept, the term ethnicity combines nature and culture and substance and code. This is not the case with quam, which entails a difference between those who brought Islam to the region, people with "foreign" origins, and those who were recipients of Islam or have "local" origins. One can be part of the same ethnic community, but fundamentally different based on genealogical origins (see Ho 2006). While all of this may not be clear from Raheem and Mahmood's conversation, as Memons are being cast "collectively" as recipients of Islam just as Bengalis were, the conception of quam entails not on essential similitude but rather a difference between ashraf and ajlaf, givers and receivers of Islamic knowledge and virtue. This distinction matters both within ethnic communities and can also be mobilized to understand relations between communities, as we see happened in the Pakistani civil war in which Bengalis were cast collectively as Hindu.

I do not mean to suggest that this is the only model of an Islamic nation nor is it one that goes uncontensted. Indeed, the Bengali national movement is clear evidence that that is not the case. Mahmood's response to Raheem also makes clear that one can reject 
the authority of the Islamic past by placing ultimate stress on the deeds of persons and communities in the present. Hence, Mahmood rejects Raheem's claims to being from noble decent by stressing how Pathans have "sold off their own country to the Americans," implying that they are colluding against Muslims and Islam. The many ethnic and linguistic movements that have arisen to challenge this form of Islamic nationalism make clear that this is a particular conception of the nation and not universally accepted. I also do not want to suggest that the categories ashraf and ajlaf are used commonly in native discourse. They are not. But, what is undeniable is the ubiquity of claims to the authority based on genealogical roots that connect one to the deep Islamic past. Moreover, it would be a mistake to think that those who cannot lay claim to privileged genealogy do not also accept its authority. Our own liberal, individualistic and egalitarian worldview compels us to see religiously based distinctions as mere justifications for economic inequality. Where we see people accept religious or cultural distinctions that place them below others, we impute false consciousness to them. Such disdain for hierarchy is itself rooted in our decided liberal valuation of individual autonomy and agency. The anthropological record stands as a testament to the enduring value placed on hierarchy in moral systems around the world (see Rio and Smedal 2009). It is only be recognizing the hierarchical form of the nation that the logic and motivations underpinning the Tablighi Jamaat becomes comprehensible. The nation as constituted by a basic distinction between ashraf and ajlaf, old and new, high and low, and pure and impure Muslims provides the backdrop for the dramatic popularity of dawat in the the last few decades. To foreground the argument of the rest of this chapter, the ranks of the Tablighi Jamaat have swelled in recent decades because dawat provides the 
possibility for low-caste Muslims to reinvent themselves into the true keepers of Islam, even if this potential is not fully realized. Dawat creates precisely those Islamic dispositions that are said to be lacking in ajlaf populations. Through dawat, one connects back to the original Islam of the Prophet. In this sense, dawat takes one back to the original generative moment of Islam and therefore negates one's own low social origins. By joining the Tablighi Jamaat, those who do not have a deep Islamic past are able to situate themselves as the creators of an Islamic future. They are able to transcend their origins and become true Islamic. The value that Tablighis appropriate to themselves through dawat allows them to rise in a sacred hierarchy.

\section{DAWAT AS (IM)MEDIATION IN THE TABLIGHI JAMAAT}

I frequently visited Abid near the Shaheen mosque in Guru Mandir, where he lived and where he was the caretaker for a small plot of land. Abid was a gregarious person with a hearty laugh, but often, like Umar, he too was afflicted by the condition of becoming "dried out" (khushka). When he was not providing service to Hazrat at the spiritual house, he would spend hours in ritual recitation. The plot had a small enclosure covered by a tin roof and in it a bench where people could rest, drink tea and escape the blistering heat in the summer. Abid had opened a small pan shop at the edge of the plot, which was managed by a young Tablighi that he had employed. To be a caretaker meant to watch over the plot and ensure that it is not forcefully occupied-a phenomenon called $q a b z a$ - a common occurrence in Karachi where land is scarce and highly valuable and where powerful, politically connected land mafias have sought to acquire any available property. For many people in Pakistan, qabza epitomizes the breakdown of ethical life as 
it flags the complete displacement of the concern for others in the service of self-interest. From the perspective of Tablighis, it is precisely this kind of extreme unethical behavior that Islam is meant to remedy.

Abid told me that he had been offered this job because people knew he was a siyana, a term that implies the quality of being clever and resourceful, at once able to manipulate others and preempt the ploys of others. Abid explained that this was in his nature (fitrat) and that, before he came to dawat, it was all directed towards "the bad" but now it is directed towards "the good." Tablighis frequently say that some characteristics (sifaat) of a person are simply God-given and dawat orients these qualities towards the good. For instance, one Tablighi explained to me how Maulana Tariq Jameel, a Tablighi who is famous throughout the world for his powerful sermons, would have been a television host or a lawyer because of his gift of speech had he not found his way to dawat. Similarly, for Abid, his street smarts - his being siyana - are a natural feature of his character, but it is through dawat that this feature of his character was turned towards the good. He was now using these qualities to protect the plot from qabza.

Noticing my amusement at his self-description, Abid launched into a narrative about how he came to the Tablighi Jamaat and how his life was before that:

We did work of shipment to Dubai, my brother and I. We were shipping gold and other valuables, mostly. They call this 'shipment' but actually it is just smuggling. .. We were actually of the Barelwi mentality, of the Barelwi sect. We did all the Barelwi practices like offerings to saints, processions, celebrating $12^{\text {th }}$ Rabi-ulAwwal, self-flaggelation, offerings to saints, roaming barefoot, basically a life of complete ignorance. Day and night absorbed in wasteful indulgence. I was always troubled, from morning to evening ... troubled about money, about time, about everything. I spent all my time watching TV and films, and I was addicted to intoxicants. Then one day, as fajr call to prayer was occurring, I asked myself, how is it that I do not even go to pray? What is the point of this kind of life? What is the purpose that I have been sent to this world for? So, I asked Allah to put me 
to whatever work He desires of me. ... Then, after two days, you know what happened? My feet automatically started moving and they took me to the Tablighis. . . . I slowly started giving dawat . . . and a revolution happened in my life. I realized that this is the truth.

It is noteworthy, here, that Abid moves effortlessly between the falsehood of Barelwi ritual practices to other unethical aspects of life like smuggling and drug use. For Abid, it goes without saying that unIslamic ritual practices in the domain of worship (ibadat) breed unethical practices in other domains of life like personal dealings (muamilat) and vice versa, and, even if there is not a causal relationship between the two, there is something of an "elective affinity" (Weber 1930). Abid draws the opposite connection between dawat and an Islamic life. Through dawat, he has come to direct his natural tendencies away from "the bad" and towards "the good."

For Abid, as for many other Tablighis I met, the Tablighi congregation provides the space through which they could purify their practices, practices that they had inherited from their families but had now come to understand as unIslamic. The range of these practices is varied but Tablighis understand them all to fit into the general category of "custom" (rivaaj), which had worldly and often Hindu as opposed to Islamic origins and needed to be purified. What was it, I thought, that unified these seemingly varied practices that rendered them all unIslamic? According to Abid, what was significant about these practices was that they were not authorized by the textual sources, the Quran and the Prophetic tradition. But, curiously, by Abid's own admission, he was not an expert in the textual tradition and had not verified whether such practices were legitimate or not. They simply were, he insisted, unIslamic. I asked Abid to explain how he knew this, and his response focused on bodily knowledge and experience: 
When one joins tabligh ... he feels that he has become Muslim on that day, that Allah has given him this gift. He begins to experience sweet smells. He begins to fear breaking Allah's command and the Prophet's ways. Allah is correcting him, giving him guidance, he is enjoying the Prophet's ways, his love for the Prophet is growing, he is feeling a joy overcome him, joy in every practice. . . when we are giving dawat, and then it is time for namaaz, and we stand for namaaz and because of the vitality of dawat, a deep pleasure fills our namaaz, a sweet taste . . a feeling that Allah is with me, is watching me, is listening to me. A Companion said that 'Oh Prophet of God, when I am with in your gathering, my condition is one way, and when I am not in your gathering my condition is completely different,' and so the Prophet said, 'this is what a religious environment will do for you.' It is like this in the Tablighi congregation too. . .

Abid's rich description of the bodily experience confirms the now well-established claim in the anthropology of Islam on how Islamic practices create bodily affects and disposition, but here, it is these bodily dispositions that are themselves evidence for the correctness of practice. When I asked Abid to explain how he knew that these practices were right, he simply told me that one knows because one feels it. He insisted that it is the Devil who uses reason and argumentation to lead people astray, while faith is about feeling and realization, so one cannot fully explain how one knows. One simply knows because one knows in the heart.

In Chapter 4, I showed that Tablighi conceptions of religion required that one situate oneself as a "listener" to pious others, and that my constantly asking questions made me a poor listener. For this reason, Tablighis perceived my research to be inimical to Islamic practice. For the longest time, I found that the end point of my conversations with Tablighis was their insistence that my research would not bring me to the truth of Islam and that such a truth had to be realized through practice. It was in correct practice that I would experience the bodily states that proved to me the truth of Islam. For people like Abid, it was the immediacy of religious experience in the body that demonstrated the 
truth of Islam. This knowledge was the effect of a "direct" relationship (bara-e-rast) to Allah created in practice and an awareness or realization of His presence. When one established this relationship in practice, one could feel His presence in one's life, which is why Abid became Muslim "on that day." It is important to note here that according to Abid, he had come to establish a direct relationship with Allah and the bodily experience of His presence through dawat. His life before dawat, by contrast, lacked this direct relationship. This contrast between a direct as opposed to an indirect relationship is worth unpacking for it structures how Tablighis think about the difference between "religion" and "custom" and between correct and incorrect practice.

Tablighis situate themselves against many "others," and it became my task, ultimately, to identity the framework that organizes the others against whom Tabighis construct themselves as Islamic subjects. These others include of course distant "others" like Westerners but many of Tablighi others are far more intimate, like Hindus, Shias, Barelwis, rural people (deihatis), the uneducated (unpadh), and the ignorant (jahil), For Tablighis like Abid, it was not long ago that they were themselves were in many ways like their others, and many people in their families remain bereft of Islam. What this means is that for a vast and growing number of Tablighis, their others are "intimate others," people with whom they have close relationships and continue to occupy a significant place in their life. As we saw with Umar's story in Chapter 5, it was one's most intimate relationships that had to be brought in line with the Islamic practice. The transformation of the self depended on the transformation of these relationships. Hence, although Tablighis sometimes speak of these others as distant and removed, they also recognize that many of them are close and intimate, and they fear, as Umar did in the last 
chapter, that they too will be dragged back into this world of corrupt practice and away from Islam.

Over the course of my research, it became clear that for Tablighis, the framework that organized "the other" was linked to the question of mediation, and central to this distinction between themselves and others was the contrast between directness and indirectness. When I pressed Abid, for instance, on what made his past unIslamic, he explained that it was his family's commitment to false authorities that kept them form embodying the Prophet's ways. Pirs, he insisted, were leading their people astray by telling them to do things that were not according to shariat and had no basis in the textual sources. I asked Abid why he thinks people listen to their pirs like this, and he explained that there are all kinds of reasons people follow their pirs, but mostly it is because they think their pirs have a special relationship to Allah. Some, he explained, claim to have a "direct line" to the Allah. Abid recognized that much of the pir-murid system was premised on genealogical authority and was familiar with the basic theory of the Light of Muhammad and how this meant that the Prophet's spirit was transmitted to his descendants through blood (khoon). He rejected such a theory in favor of orthopraxy, or living in the way of the Prophet. Anyone who wants to have "power" over others, he said, will claim to have a direct relationship to Allah and people will believe him because, "a drowning man will even grasp for a straw."

Abid believed that pirs took advantage of their followers or murid because the latter were poor and desperate. In this, Abid is reiterating the broader Deobandi critique of the pir-murid system, which they claim promises the poor and illiterate people gifts from Allah in the form of health, wealth and fertility if they can get their pirs, both living 
and dead, to intercede on their behalf. For Tablighis, such a relationship of devotion to human beings was tantamount to shirk, the elevation of another to the status of Allah, which is the gravest of all sins in Islam. I asked Talha to explain what was at stake in the difference between Deobadis and specifically Tablighis and all the other "sects" (firka) of Islam. After insisting that there are really no "sects" in Islam and that "sectarianism" (firka-wariyat) is a feature of moral chaos (fitna), Talha went on to explain that Barelwis are the closest to being "correct" (sahi) but many others have "gone too far ahead" and are almost outside the pale of Islam. Yet, it was in the Barelwis that the general problem of "the other" could be identified. Talha explained that Barelwis elevate each category of person one step above their station (maqam). For the Barelwis, he insisted, the Prophet is omnipresent like Allah, so the Barelwi use the phrase "Ya Muhammad" in which the term "ya" or "oh" is a call for the Prophet to intercede on their behalf. Talha explained that this conflates the power of Allah and the power of the Prophet. Of course, the Prophet was no ordinary human being. He was "innocent" (maasoom) and therefore not capable of sin (gunah), which means he serves as an exemplar (misaal) for humanity, but this does not allow him to intercede on our behalf. In numerous sermons, The Elders often explained how on the Day of Judgment Allah will present people with an image of the Prophet and they will be asked to recognize the Prophet. Those who fail will immediately be turned to hell. In these accounts, the Prophet, pained at the sight of his followers (ummatis) being turned towards hell, pleads with Allah to pardon them, but Allah insists that if they could not live according to his example, they must suffer the consequences. These stories mark the limits of the Prophet's powers to intercede. Just as Barelwis fail to distinguish Allah and the Prophet, they also fail to differentiate the 
Prophet and the Companions who they treat as "innocent." In a similar vein, they treat their own elders (buzurgs) like they are of the status of the Companions. In this sense, Talha explained, Barelwis, "elevate each category one level (darja)."

The issue here is what Webb Keane (2007) has aptly described as the problem of fetishism, which notes is bound up with the proper location of agency in the world. Among the Calvinist missionaries that are the focus of Keane's study, charges of fetishism entail the false attribution of agency to "things" as opposed to persons, or the failure of fetishists to properly distinguish between subjects and objects. In the Tablighi critique of Barelwis, it is the misattribution of agency to the Prophet rather than God that renders them false. Shias, Tablighis say, go even further than Barelwis as they invoke the power of Ali, the Prophet's cousin and son-in-law and the fourth Caliph, with the phrase "Ya Ali," implying that Ali has power to intercede in the world. Many Tablighis I spoke with suggested that Shias elevate Ali even above the Prophet, a commitment that would, if true, place Shias outside the bounds of Islam. Similarly, followers of popular forms of Sufism, which Tablighis refer to as pir-muridi invoke the intercessionary powers of saints. In all of these scenarios, the other is understood to be conflating transcendence with immanence, source with issue, and signified with signifier.

Charges of fetishism, as Keane explains, also imply a loss of agency on the part of the self: "By ascribing agency to things that in truth lack it, they thereby deny, perhaps rob, the agency of those who properly possess it (whether these are humans, God, or both)" (2007: $180-181)$. This threat of a loss of agency is captured in an oft-heard refrain, one frequently invoked by the Elders from the pulpit, that "Allah is not tied to the Companions. Allah is tied to practice." What this means is that there is nothing inherent 
about the Companions that made them pious. This claim places the onus of responsibility of piety in the individual Muslim, who must work to cultivate the kinds of Islamic sensibilities that enable one to live an Islamic life. Rather than depend on the mediation of others, the onus of responsibility now falls on the head of each individual Muslim to carry out the life of the Prophet. Such a perspective links inner faith to orthopraxy, making the acquisition of faith not only possible for all Muslims but a duty to be fulfilled.

While religion (din) is about affecting a proper, direct relationship to Allah, "custom" (rivaaj) entails the mediation of false authorities. In this sense, the custom/religion distinction, then, is itself constructed around the problematic of agency and how to locate it in the world. The effort to purify religion of custom, or rather reshape custom through religious practice, is an effort to reclaim the agency of the subject and to free the subject from his commitment to false authorities. This is why, in Abid's account, Muslims are tied to their pirs not out of love (mohabbat), an affective relationship that entails willful submission, but out of desperation. The distinction, then, between their own Islamic practices and the unIslamic practices of others centers on the issue of mediation, and how to create a direct relationship with Allah. For Tablighis, dawat "connects one's 'self' (zat) to Allah's self (zat)" (apni zaat ko Allah ki zat sei jor deita hai), while unIslamic practices, like those of pir-muridi, commit one to false powers.

Patrick Eisenlohr et al (2011) have argued that the desire for immediacy or directness with transcendental powers is a pervasive feature of modern religious and semiotic ideologies (see Engelke 2007). The Tablighi Jamaat fits within this broad pattern of valuing "directness" or "immediation." For Tablighis, dawat is the means to 
achieve a direct relationship with Allah, which brings with it the bodily experience as described by Abid. Dawat is what Birgit Meyer $(2006,2011)$ has called a "sensational form," which she defines as "relatively fixed modes of invoking and organizing access to the transcendental" (2011:29). Sensational forms like dawat are sacred in that they are understood by practitioners as the privileged, if not exclusive, means for creating access to the transcendental. My claim here that dawat is about "immediation" might strike the reader as being in conflict with what I have described in previous chapters about the significance of pious others. I, too, found this Tablighi insistence on "directness" to be at odds with the significance placed on the mediation of pious others. But, even in Abid's explanation of how he came to have an "immediate" relationship with Allah, he is clear that this did not happen suddenly but gradually through work in the mosque and through relationships with other Tablighis, particularly those of higher spiritual rank. It was his participation in the Tablighi congregation that brought him closer to Allah. In other words, it was the mediation of pious others that made immediation possible. It is precisely in the "mediation of immediation" that Tablighis place ultimate value.

Take for example, how Maqsood, a taxi driver and experienced Tablighi, explained to me the importance of a direct relationship with Allah:

Our [false] belief (aqeeda) is that of a child. If you ask a child who feeds you, the child says, 'my mother feeds me.' And if you ask him who feeds your mother, the child says, 'my father.' And who feeds your father? He will say my father's boss feeds him. And who feeds the boss, his boss. And the child will go on and on like this forever. We should be such that we know, "Our Allah feeds us!" [rough translation].

The child here does not recognize his relationship with Allah because in his reckoning with the world, there are multiple people that stand between him and Allah. An adult, by 
contrast, is one who has the embodied knowledge to sense beyond the more obvious, material relaties of the world to see the true operations of power. Maqsood is stating, rather unequivocally, that we must locate agency in Allah rather than in others, and it is only when we do this that we can fully understand our purpose in life, which is to fulfill our duties to Him and to live in His terms. It should be clear that Maqsood is drawing a contrast between a child who depends on the mediation of others, and an adult who understands that he depends only on Allah. The implication here is that dawat grows one's faith and thus transforms one from a child to an adult. Just as one must begin as a child and only gradually become an adult, so one begins with mediation and gradually moves to a "direct" relationship with Allah, a movement that is also one of dependency to autonomy.

The political significance of "directness" or immediation in Tablighi understandings of dawat should be understood against the cultural backdrop I provided earlier, specifically in relation to hierarchical form of the nation. As I have argued, the distinction between ashraf and ajlaf is rooted in the genealogical transmission of an Islamic habitus, a framework that divides the world between those with a deep Islamic past and "foreign" origins and those with shallow Islamic past and "local" origins. The ashraf/ajlaf distinction structures the Islamic nation in terms of givers and receivers of Islamic knowledge and virtue. This is a framework that posits a distinction between those who depend on the mediation of others and those who, because of their Islamic sensibilities, are capable of a more or less direct relationship to Allah and are thus autonomous. 
Throughout my time in the field, I found Tablighis level two charges against others that are inextricably linked. Tablighis said that Muslims have become prone to various forms of "idol worship," in which they have elevated other people or objects to the status of Allah, and two, which is directly related to this, is the claim that Muslims have descended into "ethnicity worship, which meant that rather than relate to each other as Muslims, they were divided in terms of kinship, caste and language. Muslims are not fulfilling their ritual duties because they have come to worship "worldly" powers, and as a result, they are not able to live together as Muslims, but instead find themselves divided among families, castes, ethnic communities, and nations. Dawat remedies this by creating a direct relationship with Allah as well as a "heart-to-heart" relationship between Muslims. Dawat connects Muslim to Allah and allows Muslims to stand together on "the good." In doing so, dawat creates the possibility of transcending worldly powers as well as worldly relationships, both of which are necessary for the creation of a transcendental Islamic community.

The Tablighi emphasis on the power dawat to create a direct relationship with Allah, provides the possibility of transcending one's social origins. It should be apparent that by enabling a direct relationship with Allah, dawat allows those who lack an Islamic past to become not only autonomous from those who are otherwise seen as the keepers of Islam, but crucially, they are able to become keepers of an Islam themselves. By recreating the experience of the Prophet and the Companions, dawat takes Muslims back to the world of the "original voiced presence" of Allah (Messick 1993: 26). Dawat is what Connerton (1989) has called a commemorative ritual, one that involves the reenactment of a sacred past. Tablighis conceptualize it as a ritual of remembrance (yaad 
karna) that brings the past into the present and the present into the past. Dawat takes one back to a point preceding any and all distinctions along genealogical lines, even those of the Prophet's kin. By taking a practitioner back to the original, generative moment of Islam, dawat obviates the genealogical grounds for Islamic authority and creates the potential for embodying Islamic habitus in the present. For this reason dawat provides the means for overcoming the hierarchical distinction between ashraf and ajlaf rooted in the genealogical transmission of an Islamic habitus.

Dawat is a ritual arena in which people like Abid and Maqsood who otherwise are recipients of Islam, become conveyors (literal meaning of the word tabligh) not only to those lower down, but, crucially, even to those who, according to "worldly" criteria including genealogy, are in fact above them. In this sense, dawat carries the potential to reverse the order between givers and receivers of knowledge and thus can elevate Tablighis in an Islamic hierarchy. This is the great promise of the Tablighi congregation, even if, as we saw in the last chapter, it is not always fully realized in practice. A number of things are necessary for this spiritual transformation, including the creation of a spiritual home, but this Islamic ideal is now available to all. One frequently hears personal narratives of spiritual transformation like those of Abid that juxtapose a past sullied by unIslamic “custom" against a pure Islamic present. Abid's personal narrative, and that of many others I encountered is a teleological story from past to present, custom to religion, impure to pure and mediation to immediation. If the general condition of Muslims is a degeneration from a pure Islamic past to a corrupt present, Tablighi personal narratives move in the opposite direction from a corrupted past to a pure Islamic present and towards an Islamic future. Dawat purifies and transforms one into an Islamic 
subject that propels forward an Islamic telos that culminates in the creation of an ideal Islamic nation and global Islamic community.

\section{CONCLUSION: DAWAT AS RITUAL OF TRANSCENDENCE}

I began this chapter with the argument that theories of nationalism must account for how different ontologies structure the nation. In Pakistan, the distinction between lower self and spirit at the level of the person creates a hierarchical distinction between ajlaf and ashraf populations understood in terms of low/impure and high/pure social origins. It is against this backdrop that the Tablighi Jamaat's focus on dawat truly makes sense as dawat provides the means through which one ritually purifies oneself and in doing so transcend one's "worldly" social origins. This is why, as I have argued, dawat is immensely popular among ajlaf communities. Although I was not able to conduct a formal survey, even a casual glance at the Tablighi congregation in Karachi reveals how people who cannot claim deep temporal links to Islam are among the most eager to partake in dawat. Memons, for instance, who are known for having Hindu origins, were grossly overrepresented in the congregation in Karachi. The Al-Aqsa area where I conducted my fieldwork was an overwhelmingly Memon area, and the Al-Aqsa congregation was among the most prominent in the Karachi congregation as a whole. Many of the Memons I met were middle to upper class traders. They had the resources to participate in dawat and sought, through these resources, to purify themselves and ascend an Islamic hierarchy. I encountered numerous people who could not participate fully in the Tablighi Jamaat, as it required the commitment of time and resources they did not have, but what is undeniable is the deep reservoir of desire for participation that pulsated 
in the hearts of people we encountered on the streets. Some felt shame that they were not able to participate, others committed to some practices, while still others gave us words of support. This is not a universal desire, certainly, but it was one that I found quite frequently on the streets of Karachi.

One might argue that my claim that dawat is a means to ascend an Islamic hierarchy reduces religion to some underlying social reality and therefore treats religion as epiphenomenal. I have struggled with this point. A large body of sociological literature on Muslims in South Asia lends itself to precisely this criticism. For instance, drawing on the M.N Srinavas's concept of sanskritization, in which low caste Hindus ascend a socioreligious hierarchy by emulating the dietary and ritual practices of Brahmans, numerous sociologists have argued that a similar process of ashrafization can be found among Indian Muslims in which low caste Indian Muslims adopt the ways of high caste Indian Muslims. Some sociologists have suggested a parallel ashrafization and Islamization as attemts to ascend socio-religious hierarchy (Momin 1977) but in this work, we learn very little about why it is specific symbols and practices that are the means through which Muslims ascend a socio-religious hierarchy. Why do Tablighis see dawat as the exclusive means for transcendence? Why is the Tablighi Jamaat so centrally concerned with recreating the original Islam of the Prophet through ritual? Why also, we might ask, is this process tied more broadly to the ritualization of social life?

I have tried to answer these questions and I have done so by remaining faithful to what Tablighis explained to me about dawat. In Tablighi discourse, dawat is understood as a means through which one creates faith (iman), which is what yields the capacity to live an Islamic life. Tablighis, both low and high caste, recognize that faith itself is 
unevenly distributed among Muslims throughout the world. I was repeatedly told that Arabs, who are situated at the pinnacle of this Islamic hierarchy, have such robust faith that they can live an Islamic life without even knowing it. This is not true for Pakistanis who, having lived for centuries among Hindus and other non-Muslims, need to purify their Islam of "the ways others." The distinction between Arabs and Pakistanis as a whole applies also within Pakistan as a distinction between ashraf and ajlaf communities. Tablighis, then, acknowledge the kinds of social distinctions that I have described and their grounding in the genealogical transmission of an Islamic habitus but they have drawn on an Islamic ritual ideology to create a ritual that enables one to transcend one's low social origins.

Tablighis spoke frequently about others being of lesser or greater religious rank (darja) and how those close to Allah should have power and should be followed by others. The good, they insisted, can only be spread if power is in the hands of pious people. In other words, Tablighis recognize that religiosity should confer power and influence in the world, a fact that stands in marked contrast to liberal-secular concepts of religion, in which religion should be a matter of private belief and should not be about power at all. Again, I see this as confirming my point that ascending a socio-religious hierarchy is precisely the point of dawat.

In the last and concluding chapter, I turn to what dawat can tell us about Tablighi conceptions of modernity. If dawat is a ritual of transcendence, it is so because it embodies the highest ideals of how Muslims should live and act towards each other. It entails what I call an ethics of relatedness. The significance of this ethics comes to view most fully in the Tablighi critique of Islamists political activists, who Tablighis say are 
trying to acquire power and influence through un-Islamic means. The consequence of such power, Tablighis insist, will not be well-being but mora chaos. This critique, I conclude, reveals something crucial about the kind of Islamic modernity Tablighis are aiming to create, a modernity that simultaneously stands at odds with both "traditional" understandings of Islam anchored in genealogy as well as modernist conceptions of religion associated with Islamism. In conclusion, I argue the Tablighi congregation represents a vernacular modernity that challenges any simplistic binary oppositions of hierarchy and egalitarianism, holism and individualism, and tradition and modernity. 


\section{CONCLUSION}

\section{DAWAT AS ISLAMIC MODERNITY IN PAKISTAN}

Tablighis understand practices that entail the commitment to the intercessionary powers of humans, even the Prophet, to be the primary problem associated with "custom." They regard this as a form of fetishism that elevates human beings to the status of Allah who is the only true agent in the world. The elevation of another to the status of Allah is called shirk in the Islamic tradition and is considered among the greatest of sins. For Tablighis, all intercessionary practices represent the corruption of Islam by custom, which falsely locates divine agency in human authorities rather than in Allah. Tablighis call for the purification of Islam and the demand that Muslims ought to build a direct relationship with Allah through dawat. But, Tablighis take the point a step further than many other Islamic groups who otherwise agree that intercession constitutes shirk. Tablighis say that faith is the "conviction that everything comes from Allah, and nothing comes from another." While the fetishism associated with custom has been one of the central concerns for Tablighis and arguably their primary "other," the specter of another other has increasingly come to haunt Tablighis as well. This is the threat of modernist Islam, especially as it is represented by Islamist political parties.

The conflict over whether dawat is a legitimate practice of Islam emerged throughout my fieldwork. When on preaching tours in the local neighborhood, I would witness many Muslims respectfully and reverentially decline the Tablighi invitation to the mosque. Some treated such requests with indifference and even mild amusement. Occasionally, however, one would find someone who was adamant that Tablighi forms of dawat was not only unnecessary but actually beyond the pale of Islam. One incident 
stands out in my mind. Before dusk prayers, I went to buy a water bottle from one of the many general stores built into ground floor of Mujahid mosque. The shopkeeper, a middle aged man with a long beard, told me that he had seen me come to the mosque many times and asked me if I live in the area. I responded that I do not live in the area, but I have friends who live in this area who are involved in tabligh, and I come here to listen to sermons and participate in other activities. I told him that his beard suggests that he is "religious" (dindaar), and I asked him if he was involved in dawat, to which he responded in a harsh and dismissive tone, "no!" I asked if there was a reason, and he explained to me that there is no Islamic basis for this dawat. Nowhere in the Quran or Prophetic tradition is it stated that Muslims must do this, he explained. I told him that Tablighis say that this is what the Prophet and what all other prophets in the past have done and that Muslim must do whatever the Prophet did, and the storekeeper was visibly irritated and even angered. "No, this is all innovation (bidat)." He said that Tablighi Elders have just made this up and their followers just do whatever they tell them without verifying anything for theselves. "They do not use their own reason (aql)!" Noting his irritation and knowing the sensitivity of such topics, and the fact that prayer time was approaching, I chose not to pursue the conversation any further. Later, I asked a fellow Tablighi about his adamant rejection of dawat and he told me that the shopkeeper was from an Islamist political party, the Jamaat-i-Islami.

As I noted in my introduction, Tablighis and Islamists both aim to create an Islamic society, one grounded in the authentic sources of the Quran and Prophetic tradition, but Tablighis insist that Islamist political activism does not conform to the Prophet's way and is therefore incapable of spreading Islamic virtues. For Tablighis, 
Islam can only be spread through the sacred form that embodied in the Prophet's way. Islamist political activism was, according to many Tablighis, inimical to the Prophet's ways. Moreover, because it pretended to be Islamic, it was actually leading Muslims astray and was seen as profoundly dangerous form of seduction in the world, and a ploy of the Devil. "Stay away from these organizations (tanzeem)," Maqsood the taxi driver once proclaimed. "They will only lead you away from Islam!” Similarly, Islamists, said that the Tablighi form of dawat is "innovation," a product of the teachings of Tablighi Elders, which they failed to verify through their own reason. Both Tablighis and Islamists agreed that what was needed was a return to the original sources, but Islamists were troubled by the acceptance by Tablighis of their Elders teachings. Against the charge leveled by Tablighis that Islamists have no regard for the Prophet's way, Islamists say that Tablighis fail to apply their own reason in the interpretation of Islamic sources and rely "blindly" on their elders. In other words, Islamists regard Tablighi forms of mediation, and by extension hierarchy, to be problematic.

In the rest of this chapter, I would like unpack what is at stake in the tension between Tablighis and Islamists. What is clear is that the issue here is not just doctrinal content because both Tablighis and Islamists accept the basic tenets of Deobandi Islam. Rather, what is at stake here is the very process of arriving at religious knowledge and truth. While Tablighis insist that one arrives at the truth through a ritual form of dawat, one predicated on the materiality of sacred words and actions, Islamists have increasingly adopted a modernist understanding of religion that centers on the primacy of inner belief and the sincerity of the believer, a position that treats ritualized forms, like dawat, as unnecessary. However, I do not aim to explain all of Islamism in Pakistan, let alone 
across the world, nor to do a comprehensive treatment of its diverse manifestations, many of which may not fit the contrast that I am describing here. Rather, I use Islamism here as a foil, to highlight the problems Tablighis see in a modernist epistemology that increasingly shapes Pakistani understandings of Islam. I argue that the modernist epistemology espoused by Islamists shares with liberal thought a stress on the agency and autonomy of the individual subject, and a stress that each individual should arrive at the truth through the exercise of his own reason (aql). If, for Tablighis, practices that they see as "custom" wrongly attribute agency to things and persons, rather than to God, then a modernist epistemology that places ultimate value on the individual turns "the self" into a fetish. Tablighis see the fetishism of the self or "self worship" (khud parasti) as the principal problem of modernity, one that dismantles Islamic ideals of relatedness that Tablighi regard as the foundations for an Islamic life.

\section{DAWAT AGAINST POLITIKS: A TALE OF TWO FETISHISMS}

The Tablighi concern about Islamism was forcefully brought to my attention one evening at the weekly Thursday congregation. Three Tablighi friends were discussing a mutual acquaintance of theirs, a young man in his early 20s who although not a regular Tablighi occasionally stayed after prayers to listen to sermons and participate in other mosque activities. He had potential, they insisted, because of his "passion" for Islam. But, when he suddenly stopped participating in mosque activities, they became concerned about his well-being and began seeking him out. They inquired with his family members where he had gone, and they were told that he is busy with his studies, which keeps him busy. For reasons I was not privy to, they arrived at the conclusion that he stopped his 
limited participation in the congregation because he had joined an Islamist political party at his university. They all agreed that they should try to intervene but they were worried that their intervention would drive him further away from Islam. They agreed that one of the three would visit him at his home after Friday evenings to do what in Tablighi parlance is called a "special tour" (khasoosi gasht), a kind of religious intervention that targets specific people who are seen as being sympathetic to the movement but are now drifting away. I asked why they were so worried about him if they believed he was pursuing his passion for Islam, and one of them promptly explained, "He has passion, but he is very far from practice!" Such undisciplined passion, it seemed, was a dangerous thing.

I had the opportunity to discuss the tension between Tablighis and Islamists with a few Islamist political party workers as well. I accompanied a journalist friend who was interviewing a representative of the Islamist political party, Jamaat-ud-Dawa, about their participation in rehabilitation efforts for the victims of the catastrophic floods of July, 2010 that devastated large swaths of the country and left millions of people displaced. After the interview, I asked the representative what he thought about the religious work of the Tablighi Jamaat and he responded, "We don't have any issue with them on religious grounds, but I don't understand why they don't get involved in "politics" (in English). Sometimes you have to do some things for yourself." This was characteristic of Islamist critiques Tablighi forms of dawat, which they believed relied exclusively on Allah without taking any responsibility. For Islamists, dawat itself was a weak and ineffectual form of intervention. The Tablighis stance against politics made little sense if the purpose was to create an Islamic society, which required wresting control of powerful 
institutions like the state away from unIslamic forces. In an interview I conducted with another Islamist, this time of the Jamaat-i-Islami party, he explained the position succinctly, "Pakistan is full of problems and these Tablighis only want to preach about religion. Religion is right in its own place, but we need an Islamic system (nizam) here to fix our problems, and that requires getting people involved in politics. People have to take responsibility. They cannot leave everything to Allah." He then proceeded to explain that politiks is itself "religious practice" if it is being done in "defense of Islam." What mattered was not how it was being conducted, but that it was effective in bringing about an Islamic system. This was the kind of utilitarian and instrumentalist approach to Islam that Tablighis found inimical to Islamic practice.

There are few important points to highlight about the modernist epistemology of these Islamists. First, they locate "true" Islam in the content of religious texts, and have little concern for the form of religious practice itself, which is considered ancillary and largely incidental to the meaning of the texts. Hence, even as Islamists acknowledge that Tablighis are on sure grounds in terms of doctrine, they see no reason why dawat must take a specific ritual form. Second, this leads Islamists to claim that what they are referring to above as politics can itself be religious as long as it is done with the correct intentions, the intention to further the spread of Islam in Pakistan. Third, they believe that both the content and form of dawat are largely inefficacious in addressing the concerns of Muslims in Pakistan, and thus they understand ritual to be a form of inaction. This is why they insist that taking responsibility for oneself requires doing politics, which has instrumental value in a way that ritual and prayer do not. Combined, these assumptions means that the semiotic forms that Tablighis deem "practice" is merely one arbitrary 
instrumentalization of Islamic belief. Islamists accuse Tablighis of conflating the medium for the message, form for meaning, and signifier for signified. In doing so, they are reproducing a modernist semiotic semiotic ideology that privileges inner belief over materiality and practice (see Engelke 2010)

When I told a long time Tablighi about the Islamist statements, he proclaimed definitively, "They have no faith! ... They want to do this on their own. They don't understand that only Allah can fix these problems and the only way to bring Allah to our aid is through dawat." He then went on to dismiss what Islamists do as politiks. I mark this term as different from "politics" as it is used by Islamists, because for Tablighis politics is not an essentialized domain that stands as different from "religion" in its very nature as it is in liberal theory, nor is it simply the an instrumental use of means to achieve essentially religious ends, as it is for Islamists. Note that both of these perspectives share in the perspective that religion and politics both have essential attributes are are fundamentally distinct domains of life. Rather, politiks here is a gloss that Tablighis use to refer to practices that they deem are marked by what some described to me as the "idolatry of the self" (khudparasti) and therefore a form of practice that is inimical to Islamic virtues. The above statement implied not only that politiks was unauthorized by the authoritative textual sources, a point Tablighis made frequently, but also that the Islamist perspective evidenced a lack of faith in Allah's power and an improper assumption of one's own power. The notion that Muslims must solicit Allah's aid in securing whatever they hoped to secure is captured in the first and most significant of the Tablighi Jamaat's six principles (chei batein) through which they organize their activities, the principle of faith (iman), which declares that Muslims must have "certainty 
that everything comes from Allah and nothing comes from another" (Allah ki zat sei sab kuch honei ka yaqeen, ghair ki zaat sei kuch na honei ka yaqeen). This includes, it appears, faith in one's own self. It is the failure of Islamists to live out this principle and their belief in the agency of their own self or that of some others, like their political leaders, which demonstrates their lack of faith in Allah, hence a form of idolatry.

The conflict between Tablighis and Islamists, between politics and politiks, reminds one of Webb Keane's (2007) description of the conflict between Calvinists and Sumba practitioners in the missionary encounter in Indonesia. Calvinism, Keane argues, was predicated on a semiotic ideology that drew a sharp separation between subjects and objects, persons and things, and immaterial and material domains. For Calvinists, the Sumba located agency in material objects, including ritualized words and actions, and therefore failed to locate agency in the self, the ultimate source of value. This directly parallels the Islamist critique that Tablighis fail to take responsibility for their own world. But, Keane astutely notes that fetishism is a "two way street," and if Calvinists accuse Sumba practitioners of projecting agency onto objects, Sumba practitioners counter this with the charge that Calvinist insistence on their own agency represents a form of hubris. For the Subma, practices that fail to solicit powers beyond themselves are "both ineffective and dangerous" (2007: 184 - 187). Like the Sumba, Tablighis accuse Islamists of hubris (takabbur). Some Tablighis described this in even more explicit terms as the "idoloatry of the self" (khud parasti). By locating agency in their own self rather than in divine power, Islamists conflate issue for source and signifier for signified, and fall prey to the fetishism of the self. 
Tablighis claim that this fetishism of the self inheres in Islamist political praxis

and it is not only ineffective but is also be dangerous. Maqsood, a taxi driver and long time Tablighi summed up the problem:

I knew this young man who was part of some party, and he would go off to these rallies each day, and sometimes, like us, he would even go to the villages, not for dawat of course, but he said he was going for Islam, but you know, he would come back and he would fight with his family, with his wife and beat is children also, even his parents, and he never had any peace at home. His neighbors were also all wary of him. Everyone said that he was an angry person and had hardness of temperament. . . he has passion for Islam but he is home fighting with his parents and wife. His passion is just his 'lower self' speaking, and this is what gives birth to anger and aggression in him. How is someone like this going to bring others to Islam? When we come back home from dawat, we come back with a sense of peace. It creates softness of temperament and makes us feel calm and cool ... dawat awakens your spirit and brings Allah's support."

Because it fail to take proper ritual form, Islamist politiks is not only inefficacious but also threatens to invert the Islamic order by producing undisciplined subjects who claim to represent Islam. In this narrative, the lower self is "speaking," and producing passions and dispositions that are precisely the opposite of what are induced by dawat. Contrasts of high/low, soft/hard, and cold/hot are all inverted, the former being subordinated to the latter. This inversion of value creates a person who is incapable of caring for those below (wife and children) and respecting those above (parents), i.e., a person who fails to understand and disregards his place in a hierarchical ordekr. The fetishism of the self disrupts harmonious relations in the family, between families (neighbors), and in the Islamic community more generally, creating the conditions for what in Islamic tradition more broadly is construed as moral chaos (fitna).

If dawat creates "closeness" to Allah, it should not be surprising that the ultimate model for negative value would be Iblees, the Devil himself. The Devil, in Islam, is a 
djinn, made of fire, so inherently hot and more oriented towards his lower self than his spirit. In Tablighi narratives, the Devil was the greatest worshipper of Allah and had risen, well beyond his station, to where he was among the ranks of the angels. When God asked all of his worshippers to bow before Adam, Iblees refused, insisting that he was superior to Adam, who was made of clay, on account of being made of fire. Iblees is therefore the model for willfulness and hubris, and serves as the source of all temptation and therefore of moral chaos. It is precisely this willfulness and hubris that dawat contains, creating a subject who is close to God and capable of ethical relations with others. Islamist praxis, by contrast, fetishizes the self, creating excess willfulness and hubris that undermines Islamic order.

If dawat is the basis for positive value production, then Islamist praxis is a fount for negative value production. Dawat produces a subject with a disciplined self, whose spirit speaks through them. Such a person is characterized by humility (khushu) and pious fear (khauf), and these qualities allow him to recognize his place in an Islamic hierarchy. Such a person is capable of not only living an Islamic life but also drawing others to Islam. Islamist praxis, by contrast, produces undisciplined subjects characterized by arrogance (takabbur), whose lower selves speak through them and who either commit themselves to false authorities like their political leaders or locate authority only in themselves. In both cases, they reject or are incapable of recognizing legitimate forms of authority. Such people are not only themselves "far from Islam" but also lead others away from Islam. Tablighi perceive this to be one of the central problem in Pakistan today. 
For Tablighis, the problems of Islamist politiks was not only embodied in persons, but was also objectified in institutions themselves, most notably in the Islamic state. Tablighis I spoke to mostly believed that Pakistan required the rule of virtuous Muslims, but they rejected the Islamist preoccupation with the Islamic state, because, as one Tablighi noted, “the government cannot put love in people's hearts. Only Allah can put love in people's hearts." Islamist politiks, he explained, was the pursuit of "the greatest idol," the idol of the state. But, Tablighis were not opposed to an Islamic state on principle. Like Islamists, they insisted that society must be governed by "Islamic law" (shariat), which is the central feature of an Islamic state, but this law, unlike "the law" imagined by Islamists, is understood as a process, a mode of relating hierarchically to each other and to Allah. It is not simply a law in terms of Islam content but must be Islamic in its very process (cf. Zaman 2002). In many ways, Tablighis presupposed the anthropological wisdom that "the state" is an "effect" of definite forms of practice, and a state effect created through unIslamic practice could not possibly be Islamic (Mitchell 2006). As with persons, an Islamic state created through an Islamic process would become a conduit for Allah's will, but insofar as the Islamic state was created through the false attribution of agency to someone other than Allah, it would not only fail to produce pious Muslims, it would ultimately lead Muslims away from Islam. Much of what Tablighis describe as politiks are practices that generate hubris and willfulness. The idolatry of the self and the state, for Tablighis, is one and the same. This critique was not exclusively limited to the statist project either. It applied equally to other Islamist institutions like banks and NGOs. The proliferation of "idols" was, then, the fundamental problem of modernity. 
To return, then, to my claim in the introduction, while both Tablighis and Islamists claim to be creating a society based on the doctrinal principles of Islam, they conceive of "religion" in rather different ways. For Tablighis, religion entails not only a set of doctrinal principles but, importantly, an ethic of relatedness, though which those very principles and their ethical entailments come to be embodied. Islamism, by contrast, has adopted a modernist epistemology of religion, which stresses religious content over religious form, message over medium, and belief over practice. In the former case, Islam must be spread through a ritualized form that materializes a set of ethical relationships. In the latter, religion comes to appear more as a set of propositions that need not take any particular material form, but need only be grasped by the individual mind. Such a transformation of the notion of religion implies that much of what qualifies as "religion" for Tablighis is rendered inessential by Islamists (Asad 1993). This includes not only the specific form of dawat but also the form of ethical relatedness that dawat entails. This modernist approach to religion also has implications for how Islamists conceive "politics" as an arbitray and instrumental strategy for creating an Islamic society. For Tablighis, however, this politiks entails a fetishism of the self that threatens the basis of an Islamic order.

\section{ISLAMIC PIETY IN A NEOLIBERAL AGE . . . IN TIMES OF FREEDOM}

Tablighis situate Muslim civilization in a narrative of moral degeneration and decline. The problems that besiege the Muslim world, Tablighis insist, can all be traced to the fact that Muslims have abandoned Islamic practices understood as the "ways of the Prophet," and adopted the "ways of others." According to Tablighis, the weakening of 
faith has created the deplorable state in which Muslims around the world find themselves and is reason for their subordination to non-Muslims. "When Muslims begin fulfilling fifty percent of their Islamic duties," one Tablighi explained, "the non-Muslims' ascent will stop. When Muslims reach fifty one percent of their Islamic duties, they will begin to ascend and non-Muslims will begin to descend. . . This is the power of Islamic practice" It is the purpose of the Tablighi Jamaat to "grow" and "strengthen" the faith of their fellow Muslims so that Muslims will return to Islamic practice, and through practice cultivate Islamic virtues. It is on the basis of these Islamic virtues that an Islamic community will emerge and flourish.

In Tablighi discourse, Islam must be purified of the corrupting influences of nonMuslims. The "other" in Tablighi discource refers to a variety of non-Muslims including Christians, Jews and Hindus as well as internal "others" like those who practice shirk. Stereotypes abound in the Tablighi Jamaat and they are too varied and too conflicting to fully develop here. As Bashkow (2006) has argued, the other is everywhere a foil for the resolution of tensions internal to a cultural and moral system. In Tablighi discourse, the the other is a harbinger of "impiety" (ladinyat). Tablighis understand impiety through the prism of a distinction between the spirit and the lower self in which impiety is associated with the desires of the lower self. This impiety is manifest in all manner of social ills from macro issues like economic stagnation and state corruption and violence, to unethical acts in everyday life like lying, cheating, stealing, rumor mongering, sexual impropriety, lechery among many others. The macro issues are almost always linked to the corruption of everyday relations among Muslims, corruptions rooted in the drive and desires of the lower self. 
Whatever specific form impiety takes, and usually multiple aspects are said to come together in people, the evidence for the state of impiety for Tablighis is almost always the same, the break down of ethical relationships among Muslims. When asked what the signs of this impiety are, Tablighis inevitably point to fights between husbands and wives, between parents and children, between neighbors, between ethno-linguistic communities, between sects, and even between Muslim nations. Tablighis highlight how relationships have become unreliable and uncertain and even predatory, where brothers take advantage of brothers, husbands and wives manipulate each other, neighbors steal from one another, political leaders exploit their people, and people steal from the government and so on. The breakdown of ethical relations is, for Tablighis, the sign of chaos. Indeed, this is precisely the moral dissolution that Islam is meant to remedy by inculcating virtues that allow Muslims to live as Muslims with one another. Islam is what makes these ethical relationships possible.

The Tablighi Jamaat has experienced remarkable growth since the 1980s, the same period that urban centers like Karachi, where I did my fieldwork, have been radically transformed by rapid urbanization and increasing congestion of public space as well as rising levels of literacy. The contest over public and political space has never been more intense. In Karachi, these battles have emerged along major ethno-linguistic and sectarian fault lines. Against the background of economic and political uncertainty, we are witnessing incessant calls for the need for Islamic virtue in everyday life, to forestall the moral dissolution of the Islamic nation. There is a palpable sense of crisis fills the air, and it against this backdrop that that Tablighi Jamaat's call to return to the original Islam of the Prophet and to Islamic practice has resonated (see Khan 2010). 
In Chapter 2, I described how the earliest Tablighi efforts were directed not only at offsetting the perceived threat of Hindu revivalism but also the internal threat of moral chaos created by the increasing objectification of Islam. This period was marked by fierce contestation among Muslims over the meaning and form of Islam and bitter battles over who properly represented Islam. Today, the contestation over Islam has reach unprecedented heights in Pakistan. The Tablighi Jamaat is only one in a dizzying array of Islamic forces that have risen in the last few decades. The growth of an Islamic public sphere is often attributed to the policies of the state, and specifically the Islamization campaign of the marial regime of General Zia-ul-Haq that linked state sovereignty to Islam and fostered a climate in which countless Islamic forces, including militant ones, now find themselves competing for control. State-driven recruitment and financing for the Afghan jihad in the 1980s created the rapid expansion of madrassa education and created all manner of militant Islamic forces that maintain a loose and sometimes fraught relationship to the Pakistani army and state. Since 9/11, trained militants that came out of this process have increasingly launched terrorists attack within Pakistan because they claim Pakistan is complicit in the Global War on Terror and also is promoting unIslamic activities associated with the West, especially as they pertain to inter-gender mixing.

But, one cannot attribute everything to the policies of the state. Facilitated by new information technologies and rising levels of literacy, numerous popular televangelists, radio broadcasters, new religious institutions, online groups, companies and organizations have arisen all claiming to be facilitating the creation of a more Islamic society. This is all in addition to the older Islamist political parties like the Jamaat-i-Islami. Pakistan's Islamic sphere is increasingly characterized by a "fragmentation of authority" in which 
traditional religious authorities like the 'ulema and prominent shaikhs share religious authority with a host of other contenders, including lay preachers, engineers, doctors, bureaucrats, militants, the army and the state (Eickelman and Piscatori 1996). In Pakistan, competing claims of religious authority and authenticity have themselves grown increasingly intense and dangerous over the years. This is evidenced by the rise of increased sectarianism and the takfiri practices, the tendency to declare other Muslims infidels, as well as the increased charges of blasphemy (see Ahmad 2009). Like other Pakistanis, Tablighis that I met were profoundly concerned about these developments. For Tablighis, the source of all of this is the ceaseless appropriation of Islam for politiks, which they see as the principle souce of moral chaos.

From their practice-centered approach to the world, as evidenced in Maqsood's quotation above, it was the very structure of the activities of politiks that creates dispositions that are anathema to Islamic virtues. The most outstanding aspects of politiks, from the perspective of Tablighis, was the struggle Islamists waged for recognition and legitimacy in the arenas of formal democracy and in the market, especially through the use mass media. Tablighis dismissed the many Islamic talk shows and programs for their utter failure at producing Islamic dispositions, insisting that such shows keep people from the mosque and distract people from practice. For Tablighis, the unethical qualities associated with the fetishism of the self inheres in these massmediated forms because they promote willfulness, self-interest and self-centeredness, which Tablighis contrast sharply with the virtues of Islamic piety, especially humility and pious fear. In other words, Tablighis see Islamism, which they directly associated with 
mass-mediated as opposed to face-to-face to be a source of chaos, generating the very fragmentation that dawat is meant to remedy.

This recalls an important point made by Alexis de Tocqueville (2000) in his classic Democracy in America. Tocqueville notes that in democratic societies, which he understands as those societies shaped by an ideology of egalitarian individualism, each individual understands himself to be the equal of all other individuals and therefore each individual imagines his or her own perspective to be just as valid as any other individuals. Tocqueville explains how in such a context, with all individuals being equal, "the greater truth is with the greater number" (Tocqueville 2000: 520). Tocqueville's point was that the very premise of egalitarian individualism in democracy creates a space of struggle to represent the majority view or "public opinion." In an age of democracy, all manner of institutions and interest groups emerge to claim the mantle of public opinion and that this basically became the basis of political contest in a democracy.

I draw attention to this point because this view is not far from what Tablighis understand as the problem of Islamist politiks, which they understood to be the invocation of Islam in the arena of representative politics. For Tablighis, it was the very form of representative politics with its political parties, its constant argumentation, its rallies and its struggle for control over the media that evidenced its "worldly" nature. For Tablighis, it was the practices associated with representative politics that created impious subjects because it compelled people to incessantly speak on behalf of Islam despite not having proper training or disciplined selves. Politiks, according to Tablighis, leads to a situation in which each person claims for himself the mantle of Islam, which leads to intense contestation about who represents Islam. What this means is that even those who 
otherwise live Islamic lives are corrupted by participation in this sphere of activity. Tablighis insisted that even legitimate religious authorities like the 'ulema who have been drawn in to politiks are led away from Islam. Competing claims to Islamic authority indexes the state of impiety and conflict is seen as a clear sign that the Islam being peddled by forces that are not genuinely Islamic. As one Tablighi informant noted, "there is now a pir (Sufi spiritual leader) under every rock and an 'alim (religious scholar) in every shop, but you'll never see them at the mosque!"

This explains partly why the Tablighi Jamaat has grown so dramatically since the boom in private media since 2000 and has even shifted its attention significantly away from simply a focus on reforming unIslamic "custom" in rural areas to weaning people away from politiks. For Tablighis, the incessant desire to speak and to assert oneself leads inevitably to the creation of accretions and innovations (biddat) on the original sources. In other words, mass-mediated social life is also the fount for inauthentic forms of Islam. The growing preoccupation with "talk" rather that"practice" (amal) is for Tablighis a central feature of an age of impiety, and it is precisely this impiety that Tablighis associate with moral dissolution. Talk represents the failure to accept and embody legitimate authority, especially the authority of the Elders, and results from a person imagining himself to be the ultimate arbiter of truth and morality, which Tablighis understand to be the central problem of modern life.

It is against this cacophony of "talk" that Tablighi posit their own ritualized form of dawat as a remedy. Indeed, the Tablighi Jamaat, like other Islamic piety movements, is centrally concerned with what Hirshkind (2006) has called an "ethics of listening" precisely because they perceive the problem of modernity to be one in which Muslims 
fail to listen and take instruction, lack receptivity, and refuse to be acted upon by both Allah and pious others. In other words, modernity creates people who refuse to acknowledge any authority beyond themselves. But, if the ability to listen and receive and thus embody is one feature of piety, then the other feature so apparent is the ability to speak, to communicate, or to "convey" (itself the literal translation of word tabligh) without leading others astray. How to speak, when to speak, where to speak, who to speak to, who not to speak are all questions that preoccupy Tablighis, and indeed, much of what is trained inside the movement is how to go from being a listener to being a speaker. In other words, an ethics of listening furnishes the grounds for an ethics of speaking, and an ethics of speaking then, then through the creation of faith, produces the basis for listening. Both listening and speaking are integral to what we might call the ethics of being inside the Tablighi Jamaat.

\section{AN ISLAMIC MODERNITY: SOME LESSONS FOR ANTHROPOLOGY}

When I began my research, I was inclined to think that the turn towards "piety" and away from statist Islamist movements evident in many parts of the Muslim fit with the general pattern of neoliberal modernity in that it implied a movement away from the mediation of the state or any form of authority to a more direct relationship between an individual and God. Piety, in this sense, fits with what the sociologist Asef Bayat (2013) has referred to as "post-Islamism," which is a discourse of Islam that is increasingly centered on the individual and individual self-transformation. Such transformations that do seem to be occurring among all manner of Islamic groups in Pakistan, from the rise of women's piety groups (Ahmad 2009) to Islamist political parties (Iqtidar 2011, 2013). 
Recently, anthropologists have focused on the powerful spread of what is now being called "neoliberal" Islam with its commitment to a model of autonomous selfhood associated with liberalism and its participation in a market logic associated with capitalism (see Rudnyckyj 2009).

The growing popularity of the Tablighi Jamaat movement in Pakistan not only attests to the limits of this model of Islam, it also challenges a moral narrative of modernity that imagines an inevitable movement from more collectivist and hierarchical forms of religiosity to more egalitarian and individualistic ones, a narrative that culminates ultimately in secularism or in some form of secularized religion. This trajectory of modernity is itself often linked to the rise of new media and information technologies, that make possible new forms of imagining community that are secular and egalitarian (see Anderson 1991). Certainly, there is no denying that ideals of individual agency, authenticity and autonomy are now pervasive themes in much of public life in Pakistan and throughout the world, and, as I have argued, they are now evident in religious and political movements where we might least expect them, like Islamism. Yet, despite the pervasiveness of these themes, alternate forms of religiosity like those of Tablighis not only survive but are actually flourishing. For Tablighis, the central problem of modernity is not limited to those we would conventionally understand as "secular" but extends to Islamists as well. Impiety, from this perspective, is not about "religious" or "secular" content but is materialized in the very institutional forms of bureaucracies, political parties, corporations and even an ostensibly "Islamic" state. It is the intrusion of these institutions into religious life, Tablighis insist, that is creating impiety and destroying the basis of an Islamic order. Tablighi work, by contrast, aims to 
create pious subjects who acknowledge their place and fulfill their duties in a sacred hierarchy, thereby constituting the basis for an Islamic order.

But, it is not sufficient to say that this alterity with modern individualism makes that Tablighi Jamaat simply a "traditional" Islamic movement fending off the encroachments of modernity. That would only reinscribe the very distinctions that the narrative of modernity is based on. Tablighi discourse also affirms some key aspects of conventional conceptions of "modernity" with its critique of genealogical forms of authority and intercessionary powers and its stress on a direct relationship between an individual and Allah. On the one hand, the critique of genealogical distinctions seem to conform to our general understanding of modernity, and, on the other, the Tablighis critique of the autonomous, self-realizing individual places them in what we normally associate with "traditional" society. What does one make of this modern traditionalism or traditional modernity? By way of conclusion, I would like to offer some notes towards the lessons anthropology can learn from this example of an Islamic modernity, and how it might help us move beyond our own conventional binaries of hierarchy and egalitarianism, holism and individualism and tradition and modernity, binaries that are central to the moral narrative of modernity.

The work of Louis Dumont $(1980,1986)$ has been central to the distinction between egalitarianism and hierarchy, individualism and holism and tradition and modernity. In Homo Hierarchicus (1980), Dumont argues that purity is the paramount value of Indian society. Each person is subsumed within a caste group that is hierarchically related to other caste groups in terms of their relative purity, with Brahmins at the top of the caste hierarchy and Sudras at the bottom. Each caste originates from a 
different part of the God, with Brahmins originating from the head (purity) and Sudras from the feet (impurity), and each caste derives its value from its part relative to the whole, an ideology that Dumont calls holism. Dumont contrasts Indian holism to Western individualism in which each individual is a self-contained unit of a kind similar to all other individuals. Even as Dumont has come under criticism for his depiction of Indian society from multiple perspectives (Das 1995; Dirks 2001; Van der Veer 1994), his distinction between hierarchy/holism and egalitarianism/individualism has been an immensely influential and productive model for anthropologists to understand the difference between Western individualism and traditional holism, travelling well beyond the Indian context to become central to comparative studies between Western and nonWestern traditions (see Rio and Smedal 2013).

Among the most important works to emerge out of this tradition is Marylin Strathern's now classic, The Gender of the Gift (1988). In this work, Strathern draws a sharp contrast between a Western individualism that treats the person as a bounded monad that is defined by internal attributes, which although may be modified by external relations is ultimately defined as prior to and independent of social relations. Strathern shows how this conception of the person structures the distinction between "individual" and "society" in which the former is seen as primary and natural while the latter is seen secondary and artificial. According to Strathern, the presumption of an individual that exists prior to and independently of social relations shapes Western ideas about agency as a force exerted by an individual against the impositions of society. This contrasts sharply with Melanesians ideas about persons who are "relational"and defined not by their internal attributes but by their relationships with others. This argument has been 
explicitly carried into the African context by Charles Piot (1999) who argues that for the Kabre of Togo, social relations are intrinsic to the self, which means that a person does not live in social relations so much as a person is a social relation (Piot 1999: 7)

In recent years, a number of anthropologists have criticized the tendency of anthropologists inspired by this Dumontian tradition to draw such sharp contrasts between egalitarianism and hierarchy, individualism and holism, and tradition and modernity. Janet Carsten (2004) for instance argues that the model of the Western individual in this framework erases crucial aspects of kinship and relatedness that that are present in Western societies. Drawing inspiration from Bruno Latour's (1993) famous claim that "we have never been modern," Carsten argues that dichotomies of individualism/ holism, individual/dividual, and commodities/gifts that are now foundational to anthropological theory have become placeholders for our distinctions between the West and the rest. According to Carsten, these dichotomies have largely been developed through an epistemological privileging of texts and legal sources in Western contexts, which are then contrasted with ethnographic data in what we would traditionally call "kinship" and "religion" in non-Western contexts, a fact that elides the ethnographic realities of the West (see also Ouroussoff 1993). Carsten's argument is that the notion of a "joined-up" or "relational" person that is a composite of relations is not alien to the traditions of the West even if they have been subordinated in liberal thought. Similarly, McKinnon and Cannell (2013) have recently argued that the acceptance of the individual as the normative model of personhood in the West has actually been reproduced at the analytic level in anthropological theory. They argue in the narrative of modernity, kinship and religion are believed to be limited to the domestic or private 
domain, and presumed to be absent from politics and public life more generally. This perspective excludes kinship and religion from the very boundaries of the analysis and thus affirms in theory the existence of individuals. McKinnon and Cannell show that individualism as the ideology of modernity does not represent the reality of social life in the West any more than it does in other parts of the world, which continues to be shaped by kinship and religion, even in domains like politics where ideology of modernity claims they are absent.

These arguments rightly draw attention to the possibility of alternative forms of personhood and relatedness in the West, which is a rich site for ethnographic exploration, and they also challenge, rightly I believe, the way liberal individualism, by ignoring kinship and religious forms of relatedness, is reproduced in theory itself. However, these critiques also downplay the structuring power of liberal-secularism's celebration of the free and autonomous individual and the kinds of relatedness that the ontology of egalitarian individualism posits as ideal. In other words, such critiques ignore the ethical and moral force of liberalism's insistence on the separation of private and public, domestic and legal-jural domains, and kinship/religion from law and politics, a separation imagined to be the condition for the individual's rights and freedoms (Asad 2003). McKinnon and Cannel note that the moral narrative of modernity continuously separates these domains through acts of purification, but they do not address the ethical and moral perogatives for such a separation. Put differently, if the separation of these domains is part of the ideology of liberal-secularism, this ideology posits not just what social reality actually is but also what it ought to be in order to secure certain ideals like freedom.. This 
brings to mind Asad's (2003) central claim that liberal-secularism is an ethical and political project, not merely an empirical reality but a normative one.

I draw attention to this point because ignoring the significance of modernity as a project would obscure what Tablighis are standing against, which is the value placed on the individual in both liberal-secularism and, increasingly, in Islamism. It is the effort to constitute this ideal of "modernity" that Tablighis reject. On the other hand, the Tablighi critique of an older hierarchical logic of genealogy can be seen as modern in the sense that if enables Tablighis to transcend their social origins. Islam, in the Tabighi formulation, carries a promise for a future that is radically different from the present in which a person can ascend a hierarchy, becoming something quite other than what he was. This is a powerful promise that draws countless low-caste Muslims to dawat. The Tablighi project can be understood as effort to create future that is the recreation of a sacred past, which to borrow an apt phrase from Charles Piot (2010) is a "nostalgia for the future." How might we understand this effort to create a radically different future from the cultural materials of the past? What kind of modernity do Tablighis envision against liberal-secular and Islamist modernity?

In a remarkable essay, Joel Robbins (2001) argues that although anthropologists often note that modernity is plural, vernacular and local, they rarely if ever explain what precisely is "modern" about local or vernacular modernity. Robbins notes that there is a pervasive tendency within anthropology that treats modernity as mostly a veil for traditional cultural categories and logics, which then leaves unaddressed why a vernacular modernity is any different from traditional culture other than saying that it is simply contemporaneous with Western culture. "We will have to admit," Robbins writes, 
"that modernity has some content — more content in fact than a tin can lid or a ballpoint pen - and that people who adopt it must reckon with this content" (2001: 902). Drawing on Bjorn Wittrock's (2000) definition of modernity as a set of "promissory notes," Robbins notes that modernity "points to the possibility of creating new 'assumptions about human beings, their rights and agency"'“ (Robbins 2001: 903). By seeing modernity as aspirational in this sense, many local or vernacular modernities appear to be "canonically modern" because subaltern people across the world hold such promissory notes. Once we adopt such an understanding, we can also see how modernity can be localized in an "enormous variety of ways without losing its character as a sense of a future in which these domains take different forms than they do in the present" (2001: 903).

Robbins's work focuses on how the Urapmin of Papua New Guinea who are "modern" in that their understanding of being a good Christian entails becoming a particular type of linguistic subject, one who is capable of speaking sincerely. He argues that this emphasis on sincerity runs up against their own traditional linguistic ideology in which words are simply incapable of communicating intentionality, which remains always hidden from view. One does not know, as it were, what is in another person's heart. But, simply because the Urapmin moral world is shaped by this traditional linguistic ideology does not mean they are not modern. In fact, it is precisely in the Urapmin struggle to become sincere speakers against their traditional linguistic ideology, even if this new linguistic subjectivity eludes them, is where Robbins finds their modernity. 
My argument differs slightly from Robbins in that I do not see Tablighis as striving to become the kinds of linguistic subjects that we associate with modern individualism. In fact, as I will show below, in many ways Tablighi striving is in the opposite direction, which is to say that if the Urapmin struggle to become sincere speakers against the dictates of their traditional culture, Tablighis struggle in the opposite direction to speak through an Islamic tradition in the face of the demands of liberalsecular and Islamist modernity that aim to transform religion into a set of propositions. Nevertheless, I find in this struggle something that is quintessentially modern in the sense described above, which is the struggle to create a future that is radically different from the past, or at least one's own past. I see Tablighis being people who carry a certain promissory note that only modernity could provide them with. This provisional definition of modernity explains why anthropologist Naveeda Khan (2012) should find "aspiration" and "becoming" at the center of Islamic life in Pakistan. Khan does not tie the issue explicitly to the problem of modernity, but it is in the possibility of ethical becoming that Tablighi cosmology differs from the traditional Islamic forms organized around genealogy, which limit the possibility of a direct relationship between a person and transcendental power. But, if the Tablighi Jamaat cosmology is modern in this way, it is also at the same time "vernacular" because it is structured by a ritual ideology of Islam. What one finds in the Tablighi Jamaat is not just the possibility of becoming but the claim that ethical becoming must take a particular semiotic and by implication ethical form, which is the form of dawat. This particular modality of ethical becoming, I have shown, stands at odds with Islamism, which might understand as more conventionally 
modern, at the same time that it stands against "tradition." Hence, Tablighi cosmology is a case of an Islamic modernity.

What lessons might anthropology and specifically the anthropology of religion, draw from this example of an Islamic modernity in Pakistan? I believe the grand dichotomies between individualism and holism, egalitarianism and hierarchy, or tradition and modernity, or, at the level of the person between the individual and the dividual, tend to obscure some of the most significant phenomenon in our contemporary world, like Islamic piety movements. These movements entail a struggle and striving for selftransformation and an effort recreate oneself against older forms of life deemed corrupt and unIslamic. This is the struggle that shaped many of the people that I have described in this dissertation who wanted to recreate themselves as "proper” Muslims against religious practices that they inherited from their parents, which they regarded as corrupt and unIslamic. This aspiration, I argue, is characteristic of modernity itself. In a way, to be modern is to know that your way of life will be different from that of your parents and to imbue this difference with virtue, even if this virtue has its roots in a sacred past. I believe that is what the Tablighi Jamaat offers its participants. Recognizing this helps us escape a significant and I believe narrowly conceived tendency in anthropology that Joel Robbins (2007) has aptly called "continuity thinking," which is an approach that treats all seemingly novel aspects of cultural life as expressions of already formed cultural logic that non-Western people are destined to replicate endlessly regardless of changing circumstances. In continuity thinking, everything new is merely a recreation of an older way of life and nothing novel ever seems to be created in the world. 
However, I also want to caution against the opposite tendency that has come to dominate the literature in "tradition" in anthropology. This is the approach of the "invention of tradition" school, which finds a modernist epistemology in all seemingly "traditional" aspects of life (Hobbsbawm and Ranger 1983). In this framework, traditional social forms like rituals are modern inventions that stand as symbols of an identity (usually ethnic or national). While these symbols purport to represent continuity with the ancient past, they are in fact new objects that do not actually have any link to the past. Richard Handler (1994) has noted that the emphasis on the "invention" of culture and tradition in anthropology emerged as a critique of nationalist efforts to claim for culture a timeless essence and through that to naturalize cultural boundaries that are in fact symbolically created by nationalists. Handler shows that despite the recognition that cultural essence is itself a nationalist construct, much of this literature nevertheless smuggles back in the modern assumption that units, whether persons or communities, are nevertheless constituted on the basis of similitude, for instance in the uncritical use of the term "identity." Identity, Hander notes, is not a useful cross-cultural concept because it presupposes the idea that persons and communities have essential attributes that are unique to them, a perspective that fails to see how persons and communities are not universally conceived in this way.

If conceptions of personhood and community are culturally distinct, and if "identity" is itself a feature of a modernist worldview, then we must also acknowledge that "tradition" is not simply a symbol of identity or a representation of the essence of a given community as liberal nationalists claim. This is merely one way in which "tradition" is constructed and it is constructed in this way from the standpoint of one 
particular modernist or Enlightenment tradition. Without denying that sometimes traditions are "invented" in this particular way, we cannot assume that that world has been evacuated of living traditions rooted in alternate conceptions of personhood, temporality and action. The Islamic tradition is in many ways a living tradition that has adapted itself to the demands of modernity (Asad 2003; Hirshkind 2006). As Asad has argued, the invention of tradition literature assumes a definition of tradition as essential and unchanging, rather than as an inventive and dynamic field of exchange that allows people to orient themselves to new circumstances.

The Tablighi Jamaat represents a case of how an Islamic tradition shaped by an Islamic ritual ideology can be mobilized to create a vernacular modernity that is both different from traditional forms of Islam in Pakistan as well as canonical liberal and even Islamist forms of modernity. It is no surprise, then, that the Tablighi Jamaat has been at the center of debates among South Asian historians over whether it is "traditional" (Sufi) or "modern" (reformist) movement. Understanding the Tablighi Jamaat as an Islamic modernity is precisely the way out of these debates. But, this example of Islamic modernity has a lesson for anthropology as well, which still finds itself reproducing the tired contrast of tradition and modernity in one form or another. The Tablighi Jamaat draws our attention to the aspirational quality of modernity, the pervasive desire for a present that is radically different from the past, the desire for direct and immediate relations with transcendental powers, and the desire to to ascend a socio-religious hierarchy that was once entirely out of the reach for most people but has suddently become possible. Dawat creates the possibility of realizing these desires and in the process reveals the inventiveness of an Islamic tradition in modern times. 


\section{Bibliography}

Ahmad, Asad

2009 Spectres of Macaulay: Blasphemy, the Indian Penal Code, and Pakistan's Postcolonial Predicament. In Censorship in South Asia: Cultural Regulation from Sedition to Seduction, W. Mazzarella and R. Kaur, eds. Pp. 172-205.

Bloomington: Indiana University Press.

Ahmad, Sadaf

2009 Transforming Faith: The Story of Al-Huda and Islamic Revivalism

Among Urban Pakistani Women: Syracuse University Press.

Alavi, Hamza

1972 Kinship in West Punjab Villages. Contributions to Indian Sociology, New Series. Vol. VI.

Anderson, Benedict

1991 Imagined Communities. London: Verso.

Anderson, Michael R

1993 Islamic law and the colonial encounter in British India. Institutions and Ideologies: A SOAS South Asia Reader 15(10):165.

Anderson, Paul

2011 'The piety of the gift': Selfhood and Sociality in the Egyptian Mosque Movement. Anthropological Theory 11(1):3-21.

Antoun, Richard T

1989 Muslim preacher in the modern world: A Jordanian case study in comparative perspective. Princeton: Prineton University Press.

Asad, Talal

1993 Genealogies of Religion: Discipline and Reasons of Power in Christianity and Islam. Baltimore: Johns Hopkins University Press.

2003 Formations of the Secular: Christianity, Islam, Modernity. Stanford: Stanford University Press.

Austin, John L.

1975 How to Do Things with Words. Cambridge: Harvard University Press. 
Ayres, Alyssa

2009 Speaking like a State: Language and Nationalism in Pakistan. New York:

Cambridge University Press.

Bashkow, Ira

2006 The Meaning of Whitemen: Race and Modernity in an Orokaiva

Cultural World. Chicago: University of Chicago Press.

2004 A Neo-Boasian Conception of Cultural Boundaries. American

Anthropologist 106(3): 443-458.

Basu, Helene

1998 Hierarchy and Emotion: Love, Joy and Sorrow in a Cult of Black

Saints in Gujrat, India. In Embodying Charisma. Pnina Werbner and Helene Basu, eds. Pp. 117 - 139. New York: Routledge.

Bayat, Asef, ed.

2013 Post-Islamism: The Changing Faces of Political Islam. Oxford:

Oxford University Press.

2013 Introduction: Post-Islamism at Large. In Post-Islamism:

The Changing Faces of Political Islam. Asef Bayat, ed. Pp. 3 - 34. Oxford:

Oxford University Press.

Bauman, Richard.

1977 Verbal Art as Performance. Newbury House Publishers.

Bauman, R. and Charles Briggs

1990 Poetics and Performance as Critical Perspectives on Language and Social

Life. Annual Review of Anthropology 19: 89-88

Bell, Catherine

1992 Ritual Theory, Ritual Practice. New York: Oxford University Press.

Breckenridge, C.A., and Peter van der Veer, ed.

1993 Orientalism and the Postcolonial Predicament: Perspectives on South

Asia. Philadelphia: University of Pennsylvania Press.

Bunzl, Matti

2004 Boas, Foucault, and the "Native Anthropologist": Notes toward a Neo-

Boasian Anthropology. American Anthropologist 106(3):435-442.

Butler, Judith

2005 Giving an Account of Oneself: Fordham University Press. 


\section{Carrier, James}

1991 Gifts, commodities, and social relations: A Maussian view of exchange. Sociological Forum 6: 119-136.

Carsten, Janet

2004 After Kinship: New Departures in Anthropology. Cambridge University Press.

Chatterjee, Partha

1993 The Nation and Its Fragments: Colonial and Postcolonial Histories.

Princeton: Princeton University Press.

Cohn, Bernard S

1996 Colonialism and its Forms of Knowledge: The British in India. Princeton: Princeton University Press.

Combs-Schilling, M.E.

1989 Sacred Performances: Islam, Sexuality, and Sacrifice. New York:

Columbia University Press.

Connerton, Paul

1989 How Societies Remember. New York: Cambridge University Press.

Das, Veena

1996 Critical Events: An Anthropological Perspective on Contemporary India. Dehli: Oxford University Press.

Delaney, Carol

1991 The Seed and the Soil: Gender and Cosmology in Turkish Village Society. Berkeley: University of California Press.

Dirks, Nicholas

2001 Castes of Mind: Colonialism and the Making of Modern India. Princeton: Princeton University Press.

Dumont, Louis

1980 Homo Hierarchicus: The Caste System and Its Implications. Chicago: University of Chicago Press.

1986 Essays on Individualism: Modern Ideology in Anthropological Perspective. Chicago: University of Chicago Press.

Eaton, Richard 2002 Essays on Islam in Indian History. New Dehli: Oxford University Press.

Eglar, Z.S. 
2010 A Punjabi Village in Perspective. Karachi: Oxford University Press.

Eickelman, Dale F

1978 The Art of Memory: Islamic Education and its Social Reproduction.

Cambridge University Press.

1992 Mass Higher Education and the Religious Imagination in Contemporary Arab Societies. American Ethnologist 19(4):643-655.

Eickelman, D.F. and James Piscatori 1996 Muslim Politics. Princeton: University of Princeton Press.

Eickelman, D.F. and Jon Anderson

2003 New Media in the Muslim World: The Emerging Public Sphere.

Bloomington: Indiana University Press

Eisenlohr, Patrick

2010 Materialities of Entextualization: The Domestication of Sound

Reproduction in Mauritian Muslim Devotional Practices. Journal of Linguistic Anthropology 20(2):314-333.

2011 Introduction: What is a Medium? Theologies, Technologies and Aspirations. Theme issue, "What is a Medium? Theologies, Technologies, and Aspirations," Social Anthropology 19(1):1-5.

Engelke, M.

2007 A Problem of Presence: Beyond Scripture in an African Church: University of California Press.

2010 Religion and the Media Turn: A Review Essay. American Ethnologist 37(2): 371-379.

Ewing, Katherine Pratt

2010 Anthropology and Pakistani National Imaginary. In Beyond Crisis: ReEvaluating Pakistan, Naveeda Khan, ed. Pp. 531-40. London: Routledge.

1997 Arguing Sainthood: Modernity, Psychoanalysis and Islam. Durham: Duke University Press.

1988 Shari'at and Ambiguity in South Asian Islam. Berkeley: University of California Press.

1983 The Politics of Sufism: Redefining the Saints of Pakistan. Journal of Asian Studies 42: 251-268. 
Fischer, Michael M.J.

1980 Becoming Mollah: Reflections on Iranian Clerics in a Revolutionary Age. Iranian Studies 13(1-4):83-117.

Fischer, Michael M.J. and Mehdi Abedi

1990 Debating Muslims: Cultural Dialogues in

Postmodernity and Tradition. Madison: University of Wisconsin Press.

Foucault, M., and Paul Rabinow

1984 The Foucault Reader. Pantheon Books.

Gaborieau, Marc

2006 What is Left of Sufism in Tablighi Jama'at?. Archives de sciences sociales des religions 135: $53-72$.

Gilmartin, David 1981 Kinship. Women, and Politics in Twentieth Century Punjab', in G. Minault (ed.), The Extended Family: Women and Political Participation in India and Pakistan:151-73.

1988 Islam and Empire: Punjab and the Making of Pakistan. Berkeley: University of California Press.

1998a A Magnificent Gift: Muslim Nationalism and the Election Process in Colonial Punjab. Comparative Studies in Society and History 40(03):415-436.

1998b Partition, Pakistan, and South Asian history: In Search of a Narrative. The Journal of Asian Studies 57(04):1068-1095.

Gilsenan, Michael.

1982 Recognizing Islam. London: Croom Helm.

Goffman, Erving 1981 Forms of Talk. Philadelphia: University of Pennsylvania Press.

Graham, William

1993 Beyond the Written Word: Oral Aspects of Scripture in the History of Religion. Cambridge: University of Cambridge.

Gupta, A., and J. Ferguson 1997 Anthropological Locations: Boundaries and Grounds of a Field Science. Berkeley: University of California Press.

Haeri, Niloofar 
2003 Sacred Language, Ordinary People: Dilemmas of Culture and Politics in Egypt. New York: Palgrave MacMillan.

Handler, Richard

1988 Nationalism and the Politics of Culture in Quebec. Madison: University of Wisconsin Press.

1994 Is 'identity'a useful cross-cultural concept?. In Commemorations: The Politics of National Identity, John R. Gillis, ed. Princeton: Princeton University Press. Pp. 27-40.

2004 Mysteries of Culture: Afterword. American Anthropologist 106(3): 488494.

Hirshkind, Charles.

2006 The Ethical Soundscape: Cassette Sermons and Islamic Counterpublics. New York: Columbia University Press.

Hefner, Robert W.

2000 Civil Islam: Muslims and Democratization in Indonesia. Princeton:

Princeton University Press.

Ho, Engseng

2006 The Graves of Tarim: Genealogy and Mobility across the Indian Ocean. Berkeley: University of California Press.

Hobsbawm, E., and T.O. Ranger

1992 The Invention of Tradition. Cambridge: Cambridge University Press.

Human Rights Commission Pakistan

2011 The State of Human Rights Annual Report.

Huntington, Samuel

1996 The Clash of Civilizations and the Remaking of World Order. New York:

Simon \& Shuster.

Iqtidar, Humeira

2011 Secularizing Islamists? Jama'at-e-Islami and Jama'at-ud-Da'wa in Urban Pakistan. Chicago: University of Chicago Press.

2013 Post-Islamist Strands in Pakistan: Islamist Spin-offs and their Contradictory Trajectories. In Post-Islamism: The Changing Faces of Political Islam. Asef Bayat, ed. Pp. 257 - 276. Oxford: Oxford University Press.

Jaffrelot, Christophe

2002 Pakistan: nationalism without a nation. Zed Books. 
Jalal, Ayesha

1985 The Sole Spokesman: Jinnah. The Muslim League and the Demand for Pakistan. Cambridge: Cambridge University Press.

1995 Conjuring Pakistan: History as Official Imagining. International Journal of Middle East Studies 27 (1): 73-89.

Keane, Webb

2003 Semiotics and the Social Analysis of Material Things. Language and Communication 23: $409-425$.

2007 Christian Moderns: Freedom and Fetish in the Mission Encounter. Berkeley: University of California Press.

2010. Minds, Surfaces, and Reasons in the Anthropology of Ethics.

In Ordinary Ethics: Anthropology, Language and Action, ed. Michael Lambek. Pp. 64 - 101. New York: Fordham University Press.

Kapferer, Bruce

1989 Nationalist ideology and a Comparative Anthropology. Ethnos 54(34):161-199.

Khan, Naveeda, ed. 2010. "Introduction." In Beyond Crisis: Re-evaluating Pakistan. Pp. 1 - 30. London: Routledge.

2012 Muslim Becoming: Aspiration and Skepticism in Pakistan. Durham: Duke University Press.

Kurin, Richard

1980. Person, Family and Kin in Two Pakistani Communities. PhD diss., University of Chicago.

Laidlaw, James

2002 For an Anthropology of Ethics and Freedom. Journal of the Royal Anthropological Institute 8(2):311-332.

Lambek, Michael.

1990 Certain Knowledge, Contestable Authority: Power and Practice on the Islamic Periphery. American Ethnologist 17(1):23-40.

1993 Knowledge and Practice in Mayotte: Local Discourses of Islam, Sorcery, and Spirit Possession. Toronto: University of Toronto Press. 
2010 Ordinary Ethics: Anthropology, Language, and Action. New York: Fordham University Press.

Latour, B.

1993 We Have Never Been Modern. Cambridge: Harvard University Press.

Lindholm, Charles

1998 Prophets and Pirs: Charismatic Islam in the Middle East and

South Asia. In Embodying Charisma. Pnina Werbner and Helene Basu, eds. Pp. 209 - 233. New York: Routledge.

Lefebvre, Alain

2014 Kinship, honour and money in rural Pakistan: subsistence economy and the effects of international migration. New York: Routledge.

Lelyveld, D.

1978 Aligarh's First Generation: Muslim Solidarity in British India. Princeton: Princeton University Press.

1993 The Fate of Hindustani: Colonial Knowledge and the Project of a National Language. In Orientalism and the Postcolonial Predicament: Perspectives on South Asia. Peter van der Veer and Carol Breckendridge, eds. Pp. 189 - 214. Philadelphia: University of Pennsylvania Press

Lewis, B.

2001 What Went Wrong?: Western Impact and Middle Eastern Response:

Oxford University Press.

Mahmood, Saba.

2001 Rehearsed Spontaneity and the Conventionality of Ritual: Disciplines of Salat. American Ethnologist 28 (4): 827-853

2005 Politics of Piety: The Islamic Revival and the Feminist Subject. Princeton: Princeton University Press.

Maine, H.S.

1861 Ancient Law. London: Murray.

Makdisi, George.

1983 Institutionalized Learning as a Self-Image of Islam.

In Islam's Understanding of Itself. Speros Vryonis.ed. Pp. 73 - 85 Los Angeles: University of California Press.

Mani, Lata

1998 Contentious Traditions: The Debate on Sati in Colonia India. Berkeley: University of California Press. 
Masud, M.K., ed.

2000 Travellers in Faith: Studies of the Tablīghī Jamā' at as a Transnational Islamic Movement for Faith Renewal. Brill.

Mauss, Marcel, and W.D. Halls

1954 The Gift: Forms and Functions of Exchange in Archaic Societies. W.W. Norton.

McKinnon, Susan

1995 Houses and Hierarchy: The View From A South Moluccan Society. In About the House: Levi-Strauss and Beyond. Janet Carsten and Stephen HughJones, eds. Pp. 170 - 188. Cambridge University Press.

McKinnon, Susan and Fenella Cannell, eds. 2013 The Difference Kinship Makes. In Vital Relations: Modernity and the Persistant Life of Kinship. Susan McKinnon and Fannella Cannell, eds. Pp. 3-39. Sante Fe, New Mexico: School for Advanced Research Press.

Messick, Brinkley

1993 The Calligraphic State: Textual Domination and History in a Muslim Society. Berkeley: University of California Press.

Metcalf, B.D.

2006 Islamic Contestations: Essays on Muslims in India And Pakistan: Oxford University Press, Incorporated.

Meyer, Birgit

2011 Mediation and Immediacy: Sensational Forms, Semiotic Ideologies and the Question of the Medium. Theme issue, "What is a Medium? Theologies, Technologies, and Aspirations," Social Anthropology 19(1):23-39.

Meyer, B., and A. Moors, eds.

2005 Religion, Media, and the Public Sphere. Bloomington: Indiana University Press.

Mitchell, Timothy 2006 State, Economy, and the State Effect. In The Anthropology of the State: A Reader. Ardhana Sharma and Akhil Gupta, eds. Pp. 169 - 189. Blackwell Publishing Limited.

Mittermaier, Amira

2011 Dreams That Matter: Egyptian Landscapes of the Imagination. Berkeley: University of California Press.

Munn, Nancy 
1986 The Fame of Gawa: A Symbolic Study of Value Transformation in Massim (Papua New Guinea) Society. Cambridge: Cambridge University Press.

Murata, Sachiko

1992 The Tao of Islam: A Sourcebook on Gender Relationships in Islamic Thought. New York: State University of New York Press.

Narayan, Kirin

1993 How Native Is a "Native" Anthropologist? American Anthropologist 95(3):671-686.

Ouroussoff, Alexandra

1993 Illusions of rationality: false premisses of the liberal tradition. Man:281298.

Pandey, Gyan

1990 The Construction of Communalism in Colonial North India. Oxford University Press.

1999 Can a Muslim be an Indian? Comparative Studies in Society and History 41(04):608-629.

Parkin, D.J., and S.C. Headley,eds.

2000 Islamic Prayer Across the Indian Ocean: Inside and Outside the Mosque. Curzon.

Peirce, C.S., and J. Buchler

1955 Philosophical Writings of Peirce: Dover Publications.

Piot, Charles

1999 Remotely Global: Village Modernity in West Africa. Chicago: University of Chicago Press.

2010 Nostalgia for the Future: West Africa after the Cold War. Chicago: University of Chicago Press.

Reetz, Dietrich

2006 Islam in the Public Sphere: Religious Groups in India, 1900 1947. Delhi: Oxford University Press.

Ring, Laura

2006 Zenana: Everyday Peace in a Karachi Apartment Building. Bloomington: Indiana University Press. 
Rio, K.M., and O.H. Smedal 2013 Hierarchy: Persistence and Transformation in Social Formations. New York: Berghahn Books.

Robbins, Joel

2001a God is Nothing but Talk: Modernity, Language, and Prayer in a Papua New Guinea Society. American Anthropologist 103(4):901-912.

2001b Ritual Communication and Linguistic Ideology: A Reading and Partial Reformulation of Rappaports Theory of Ritual. Current Anthropology 42(5):591614.

2001c Secrecy and the Sense of an Ending: Narrative, Time and Everyday Millenarianism in Papua New Guinea and in Christian Fundamentalism. Society for the Comparative Study of Society and History, 10/4175/01:525 - 551.

2007 Continuity Thinking and the Problem of Christian Culture. Current Anthropology 48(1):5-38.

Robinson, Francis

2001 The 'Ulama of Farangi Mahall and Islamic Culture in South Asia. Orient Blackswan.

Roy, Olivier

1994 The Failure of Political Islam. Cambridge: Harvard University Press.

2004 Globalized Islam: The Search for a New Ummah: Columbia University Press.

Rudnyckyj, Daromir

2009 Market Islam in Indonesia. Theme Issue "Islam, Politics, Anthropology," Journal of the Royal Anthropological Institute 15: 183-201.

Sanyal, Usha

1996 Devotional Islam and Politics in British India. Ahmad Riza Khan: Barelwî and his Movement, 1870-1920. Delhi: Oxford University Press.

Schimmel, A.

1975 Mystical Dimensions of Islam: University of North Carolina Press.

Schneider, D.M.

1980 American Kinship: A Cultural Account. Chicago: University of Chicago

Press. 
Segal, Daniel and Richard Handler 2006 Cultural Approaches to Nationalism. The SAGE Handbook of Nations and Nationalism. London: SAGE Publications Ltd.

Shaikh, Farzana

2009 Making Sense of Pakistan. New York: Columbia University Press.

Shielke, Samuli.

2009 Being Good in Ramadan: Ambivalence, Fragmentation and the Moral Self in the Lives of Young Egyptians. Journal of Royal Anthropological Institute 2440 .

Shryock, Andrew.

1997 Nationalism and the Genealogical Imagination: Oral History and Textual Authority in Tribal Jordan. Berkeley: University of California Press.

Sikand, Yoginder

2002 Origins and Development of the Tablighi Jama'at (1920-2000):

A Cross Country Comparative Study. London: Sangam Books Ltd.

Silverstein, B.

2011 Islam and Modernity in Turkey. New York: Palgrave Macmillan.

2008 Disciplines of Presence in Modern Turkey: Discourse, Companionship and the Mass Mediation of Islamic Practice. Cultural Anthropology 23 (1):118 - 153.

Stasch, Rupert

2011 Ritual and Oratory Revisited: The Semiotics of Effective Action. Annual Review of Anthropology 40:159-174.

Tocqueville, Alexis de

[1835] 2000 Democracy in America. New York: Bantam Dell.

Toor, Saadia

2011 The State of Islam: Culture and Cold War Politics in Pakistan. Pluto Press.

Trilling, Lionel

1972 Sincerity and Authenticity: Harvard University Press.

\section{UNESCO}

2003 Literary Trends in Pakistan: UNESCO office, Islamabad.

Van der Veer, Peter

1992 Playing or Praying; A Sufi Saint's Day in Surat. Journal of Asian Studies 51(3): 545-564. 
1993 The Foreign Hand: Orientalist Discourse in Sociology and Communalism. In Orientalism and the Postcolonial Predicament. Peter van der Veer and Carol Breckendride, eds. Pp. 23-45. Philadelphia: University of Pennsylvania Press.

1994 Religious Nationalism: Hindus and Muslims in India. Dehli: Oxford University Press.

Verkaaik, Oscar

2004 Migrants and Militants: Fun and Urban Violence in Pakistan. Princeton: Princeton University Press.

Warner, Michael

2002 Publics and counterpublics. Public culture 14(1):49-90.

Washbrook, David A

1981 Law, state and agrarian society in colonial India. Modern Asian Studies 15(03):649-721.

Watt, Montgomery

1999 Islam: A Short History. Oneworld Press.

Weber, M., and S. Kalberg

2001 The Protestant Ethic and the Spirit of Capitalism. Fitzroy Dearborn.

Werbner, Pnina.

2005 Pilgrims of Love: The Anthropology of a Global Sufi Cult. Bloomington: Indiana University Press.

Werbner, Pnina and Helene Basu, eds.

1998 Embodying Charisma. New York: Routledge.

1998 Introduction: The Embodiment of Charisma. In Embodying Charisma. Pp. 3 - 30. New York: Routledge.

Wittrock, Björn

2000 Modernity: One, none, or many? European Origins and Modernity as a Global Condition. Daedalus:31-60.

Woodward, Mark R.

1989 Islam in Java: Normative Piety and Mysticism in the Sultanate of Yogyakarta. Tucson: University of Arizona Press.

Wright, Theodore $\mathrm{P}$.

1991 Center-Periphery Relations and Ethnic Conflict in Pakistan: Sindhis, Muhajirs, and Punjabis. Comparative Politics:299-312. 


\section{Zaman, Qasim}

2002 The Ulama in Contemporary Islam: Custodians of Change.

Princeton: Princeton University Press 